
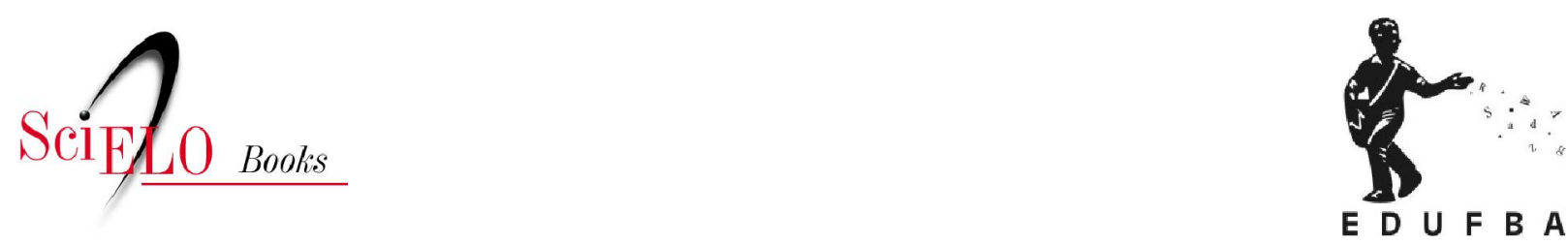

\title{
A larga barra da baía \\ essa província no contexto do mundo
}

\author{
Milton Moura
}

SciELO Books / SciELO Livros / SciELO Libros

MOURA, M., org. A larga barra da baía: essa província no contexto do mundo [online]. Salvador: EDUFBA, 2011, 242p. ISBN 978-85-232-1209-4. Available from SciELO Books $<$ http://books.scielo.org $>$.

\section{(c) $\underset{\mathrm{BY}}{\mathrm{NC}}(\mathrm{O}$}

All the contents of this chapter, except where otherwise noted, is licensed under a Creative Commons Attribution-Non Commercial-ShareAlike 3.0 Unported.

Todo o conteúdo deste capítulo, exceto quando houver ressalva, é publicado sob a licença Creative Commons Atribuição - Uso Não Comercial - Partilha nos Mesmos Termos 3.0 Não adaptada.

Todo el contenido de este capítulo, excepto donde se indique lo contrario, está bajo licencia de la licencia Creative Commons Reconocimento-NoComercial-CompartirIgual 3.0 Unported. 


\section{a larga barra da baía \\ essa província no contexto do mundo}
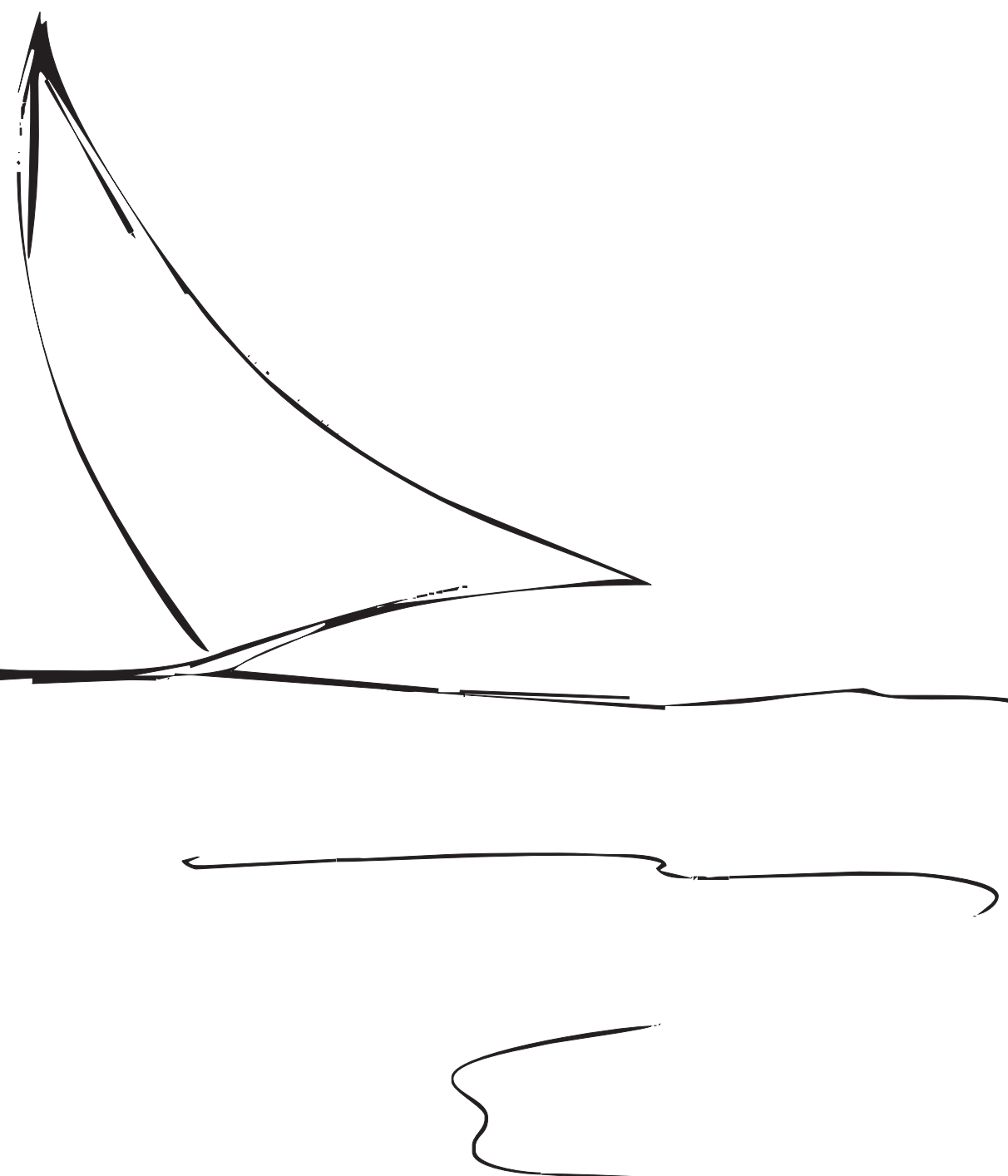
UNIVERSIDADE FEDERAL DA BAHIA

Reitora

Dora Leal Rosa

Vice-Reitor

Luiz Rogério Bastos Leal

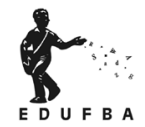

EDITORA DA UNIVERSIDADE FEDERAL DA BAHIA

Diretora

Flávia Goullart Mota Garcia Rosa

Conselho Editorial

Titulares

Alberto Brum Novaes

Ângelo Szaniecki Perret Serpa

Caiuby Alves da Costa

Charbel Ninõ El-Hani

Dante Eustachio Lucchesi Ramacciotti

José Teixeira Cavalcante Filho

Suplentes

Evelina de Carvalho Sá Hoisel

Cleise Furtado Mendes

Maria Vidal de Negreiros Camargo 


\section{a larga barra da baía \\ essa província no contexto do mundo}

MILTON MOURA (org.)

Edufba

Salvador | junho | 2011 
(C)2011 by Autores.

Direitos de edição cedidos à EDUFBA. Feito o depósito legal.

Projeto Gráfico, Editoração Eletrônica

Alana Gonçalves de Carvalho Martins

Fotografia da Capa

Alana Gonçalves de Carvalho Martins

Revisão

Fernanda Machado

Normalização

Adriana Caxiado

A larga barra da baía : essa província no contexto do mundo / Milton Moura (org.). - Salvador : EDUFBA, 2011.

$242 \mathrm{p}$.

ISBN - 978-85-232-0777-9

1. Cultura popular - Salvador (BA). 2. Descrições e viagens -

Salvador (BA). 3. Carnaval - Salvador (BA). 4. Capoeira - Bahia. 5. Música - Bahia. 6. Imaginário - Bahia. I. Moura, Milton.

$$
\text { CDD - } 306
$$

Editora filiada à:

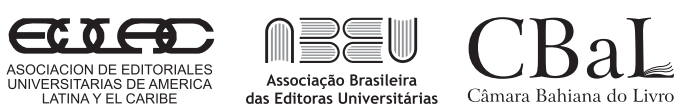

EDUFBA

Rua Barão de Jeremoabo, s/n, Campus de Ondina, 40170-115,

Salvador-BA, Brasil

Tel/fax: (71) 3283-6164

www.edufba.ufba.br | edufba@ufba.br 


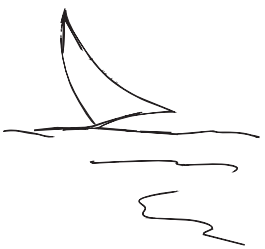

a todos que carregam mercadorias e sentidos por cima do mar 
09 ABERTURA

18 Olhares estrangeiros impressões dos viajantes acerca da Bahia no transcurso dos oitocentos OLÍVIA BIASIN
56 "A Bahia não se desnacionaliza" modernidade, civilidade e permanência dos costumes na Salvador republicana

EDILECE SOUZA COUTO
86 O oriente é aqui o cortejo de referências fantásticas de outros mundos no Carnaval de Salvador

MILTON MOURA 
130 Capoeira Angola africana, baiana, internacional

CHRISTINE NICOLE ZONZON
166 Musique baianaise?

Representações da Bahia e do Brasil entre produtores musicais franceses

LUCIANA VASCONCELOS
196 Axé music mitos, gestão e world music ARMANDO ALEXANDRE CASTRO 



\section{ABERTURA}

No século XVI, os cronistas se encantavam com a largura da Baía de Todos os Santos. Tudo lhes parecia grandiosidade, nobreza, distinção, magnitude. Em 1570, Pero de Magalhães Gândavo (1980, p. 29) afirmava:

Esta Capitania tem huma bahia muito grande e fermosa, há três legoas de largo, e navega-se quinze por ella dentro, tem muitas ilhas de terras mui viçosas que dão infinito algodão; divide-se em muitas partes essa bahia: e tem muitos braços e enseadas dentro. Os moradores da terra todos se servem por ella com barcos pera suas fazendas.

Alguns anos mais tarde, em 1587, referindo-se a umas das expedições exploradoras portuguesas do início do mesmo século, Gabriel Soares de Souza (200o, p. 4) escreveria:

[...] e andando correndo a costa, foi dar com a boca da Bahia, a que pôs o nome de Todos os Santos, pela qual entrou dentro, e andou especulando por ela todos os seus 
recôncavos, em um dos quais, a que chamam o rio do Paraguaçu, achou duas naus francesas que estavam ancoradas resgatando com o gentio, com as quais se pôs às bombardas, e as meteu no fundo.

É possivelmente o primeiro registro escrito em português sobre a disputa da Baía por diferentes nações europeias. O cuidado disto, entre outras razões, impulsionaria o estabelecimento dos portugueses ao longo da costa; tão bela e rica região também estaria despertando a cobiça de seus vizinhos.

A largura da Baía viria a ser retomada na Carta Ânua escrita pelo noviço Antônio Vieira (1995, p. 152-153), em 1625, ao Padre Geral da Companhia de Jesus:

Abre esta costa do Brasil, em treze graus da parte do sul, uma boca ou barra de três léguas, a qual, alargando-se proporcionalmente para dentro, faz uma baía tão formosa, larga e capaz que, por ser tal, deu o nome à cidade, chamada por antonomásia - Bahia. Começa da parte direita em uma ponta, a qual, por razão de uma igreja e fortaleza dedicada a Santo Antônio, tem o nome do mesmo santo; e, correndo em meia lua espaço de duas léguas, se remata em uma língua de terra, a que deu o nome de Nossa Senhora de Monteserrate, uma ermida consagrada à mesma Senhora. No meio desta enseada, com igual distância de ponta a ponta, está situada a cidade no alto de um monte, íngreme e alcantilado pela parte do mar.

\section{Duas páginas adiante, diz que a Baía era tão larga que aí tam- bém podiam entrar com facilidade outros navegantes...}

Com a luz do dia seguinte apareceu a armada inimiga, que repartida em esquadras vinha entrando. Tocavam-se em todas as naus trombetas bastardas a som de guerra, que com o vermelho dos paveses vinham ao longe publicando sangue. Divisavam-se as bandeiras holandesas, flâmulas e estandartes que, ondeando das antenas e mastaréus mais altos, desciam até varrer o mar com tanta majesta- 
de e graça que, a quem se não temera, podiam fazer uma alegre e formosa vista. Nesta ordem se vieram chegando muito a seu salvo sem lho impedirem os fortes, porque, como o porto é tão largo, tinham lugar para se livrar dos tiros. (VIEIRA, 1995, p. 154)

Na mesma década, o Frei Vicente do Salvador (1982, p. 112) nos oferece uma explicação sobre o nome da terra, retomando o problema da largura da Baía de forma muito semelhante:

Toma essa capitania o nome da Bahia por ter uma tão grande que por antonomásia e excelência se levanta com o nome comum e apropriando-se a si se chama a Bahia, e com razão, porque tem maior recôncavo, mais ilhas e rios dentro de si que quantas são descobertas em o mundo, tanto que, tendo hoje cinqüenta engenhos de açúcar e para cada engenho mais de dez lavradores de canas de que se faz o açúcar, todos têm seus esteiros e portos particulares; nem há terra que tenha tantos caminhos, por onde se navega. As ilhas que dentro de si tem, entre grandes e pequenas, são trinta e duas: só tem um senão que é não se poder defender a entrada dos corsários, porque tem duas bocas ou barras uma dentro da outra: a primeira a leste da ponta do padrão da Bahia ao morro de São Paulo, que é de doze léguas, a segunda, que é a interior, do sul da dita barra ou ponta do Padrão à ilha de Taparica, que é boca de três léguas.

Na segunda metade do século XVII, quando a cidade conheceu sua maior importância na trama do império, Gregório de Matos (1999, p. 333) veria na Baía um paradigma da compreensão de sua inserção no mundo, associando a largueza da barra à dinâmica do mercantilismo:

Triste Bahia! Oh, quão dessemelhante Estás, e estou do nosso antigo estado! Pobre te vejo a ti, tu a mi empenhado, Rica te vejo eu já, tu a mi abundante 
A ti trocou-te a máquina mercante

Que em tua larga barra tem entrado

A mim foi-me trocando, e tem trocado

Tanto negócio e tanto negociante.

A abertura da Baía, tão decantada inicialmente pela generosidade, colocava então desafios tanto em termos de entendimento como de gestão. No século XIX, diferentes aportes, vindos de europeus de diversas nacionalidades, viriam enriquecer a construção desta problemática, que se desdobraria em multiplas direções no século XX.

Prezado leitor, após esta digressão atipicamente colocada no início do volume, cabe dizer que foi a partir da consideração destas e de outras diferentes miradas da Baía como metáfora e metonímia da Bahia, compreendida aqui como Salvador e o Recôncavo, que esta coletânea aconteceu. A forma e as dimensões da Baía de Todos os Santos se estabelecem, historicamente, como uma figura da problematicidade de sua interação com o mundo. O que entra e sai através de tantas águas? Esta pergunta parece configurar a tensão entre o local e o mundial já desde aquelas épocas. A partir destas provocações que se distanciam no tempo cronológico, sem prejuízo de sua prerrogativa de interpelar o passado mais próximo, o presente e o futuro, trata-se de estudar, a partir de alguns painéis temáticos, a relação que um lugar vem estabelecendo com o mundo nos últimos séculos.

Com efeito, a partir do século XIX, se por um lado a Bahia era uma província importante no contexto da jovem nação, manteve, por outro lado, aspectos de dependência e assimetria de desenvolvimento em comparação a outros centros. Em contrapartida, pôde sustentar um papel destacado na dinâmica das representações da identidade brasileira - sobretudo no campo artístico - que vem se renovando como objeto de interesse de estudiosos, brasileiros ou adventícios. Enfim, a perda de sua condição de capital colonial 
não se incompatibilizou com uma importância remetida a algumas dimensões fundantes da brasilidade, sobretudo a origem africana da maior parte de sua gente. Seu porto testemunhava diariamente a troca de mercadorias e referências identitárias com a Europa, a África e o Oriente.

A compreensão que vínhamos fazendo de nossa configuração cultural entrelaça-se continuamente com a relação que estabelecemos com outras praias do mundo. Mesmo a função da Bahia no concerto da brasilidade passa pela sua importância como emblema da ascendência africana da nação brasileira. Aos efeitos desta reflexão, não interessa tanto uma contabilidade do número ou das proporções de africanos alocados nas diferentes províncias do Brasil. Antes, essa configuração da Bahia como umbigo negro brasileiro se situa no campo das representações. Não se trata tanto de estatísticas, mas de construções em permanente conflito, surdo ou sonoro.

As elites governantes da República Velha, amparadas em intensa atividade de jornalistas e parlamentares, queriam ver banidas da Bahia as marcas da colonização portuguesa e da escravidão. Afinal, os estrangeiros se mostravam tão maravilhados com a paisagem quanto enauseados diante de seus odores. Xavier Marques escreveu, em 1897, como que um epitáfio do Entrudo, situado numa narrativa remetida à oitava década do século XIX e marcada pela fricção contínua de áfricas e europas:

Franca hostilidade declarara-se aos jogos d'água. As autoridades empenhavam-se à porfia em suprimir os banhos anacrônicos e funestos: ensaiavam rasgar ao povo os horizontes do verdadeiro Carnaval, à européia, mascarado, risonho, castigador [...] No teatro haveria bailes; a Nova Euterpe abriria o seu salão aos dominós; nas praças tocariam fanfarras; um clube se preparava para passear as ruas. (MARQUES, 1975, p. 121) 
A tradição dos orixás conseguiu engastar a marca e a memória da africanidade na sociedade de Salvador, Recôncavo e ilhas. Mais tarde, também a capoeira envergaria este papel. De outra forma, o candomblé de caboclo soube cultivar a memória do ancestral indígena mesmo depois do desaparecimento de suas formas de vida econômica e política. Somada a estes elementos, com a chegada do cinema, a iconografia do Oriente encheria os olhares dos públicos ávidos de outros mundos, não apenas por lhes parecerem belos e brilhantes, como também porque neste preciso mundo da província nem todo mundo tem vez.

O sucesso que teve a implantação do nome da Bahia no acervo de representações da brasilidade na radiofonia - já antes de Carmem Miranda, com os compositores e intérpretes da Casa Edison no Rio de Janeiro - tensionou sobremaneira esta dinâmica de presentificações. A música feita na Bahia ou sobre a Bahia tem tido êxito em diversos mercados estrangeiros, desde o soprano Elsie Houston, passando por Dorival Caymmi e tantos outros e desdobrando-se, recentemente, na axé music. A barra da Baía tem se mostrado muito larga, com grande variedade de artigos entrando e saindo, cada vez mais rapidamente, através de seus diversos tipos de caravelas e bergantins, lanchas e transatlânticos, saveiros, catraias e ferry-boats. Tem sido necessário e prazeroso se posicionar com frequência nesta trama de caras e bocas.

Estes aspectos da história cultural da sociedade baiana tomaram forma nas discussões promovidas pela pesquisa Beduíno com Ouvido de Mercador - um documentário sobre o Carnaval de Salvador dos anos 50 aos 801, realizada entre 2007 e 2009 pelo Grupo O Som do Lugar e o Mundo, ligado à Faculdade de Filosofia e Ciências Humanas da Universidade Federal da Bahia. As questões que, de partida, remetiam-se diretamente ao campo

1 Realizada com o apoio da Fundação de Amparo à Pesquisa do Estado da Bahia FAPESB. 
do Carnaval, reconfiguravam-se de forma a fazer sentido com relação a outros objetos de investigação. Quando da conclusão dos trabalhos, foi delineado então o perfil da coletânea. Os capítulos expressam resultados de diversos trabalhos interfaciados nas discussões ampliadas.

O capítulo 1: Olhares estrangeiros: impressões dos viajantes acerca da Bahia no transcurso dos oitocentos, de Olívia Biasin, analisa as crônicas dos estrangeiros sobre Salvador no século XIX, quando a cidade mantinha notável visibilidade no cenário nacional e internacional, o que se depreende pelas expectativas expressas pelos viajantes. A riqueza e a exuberância da fauna e da flora, bem como o componente humano -, especialmente o negro - sobressaíam-se como elementos distintivos.

O capítulo 2, "A Bahia não se desnacionaliza”: modernidade, civilidade e permanência dos costumes na Salvador republicana, de Edilece Souza Couto, trata da polêmica em torno das intervenções urbanísticas no final do século XIX, quando os políticos e intelectuais baianos desejavam modernizar sua capital. O modelo predominante vinha de Paris, Rio de Janeiro e São Paulo. Os ideais de civilização assumiram dimensões sociais e culturais, sendo que as elites buscavam purificar a cidade de suas marcas do passado e de sua herança africana.

O capítulo 3, O oriente é aqui - o cortejo de referências fantásticas de outros mundos no Carnaval de Salvador, de Milton Moura, debruça-se sobre as recriações alegóricas de outros mundos no universo do Carnaval soteropolitano dos anos 50 aos 80, destacando a experiência da fantasia propriamente dita, elemento onírico que organiza e confere sentido à dimensão supostamente mais real do viver. As referências aportadas pelo cinema, sobretudo os filmes orientalistas e de farwest, reconfiguram representações da cidade em relação ao mundo, especialmente no âmbito da etnicidade. 
O capítulo 4, Capoeira Angola: africana, baiana, internacional, de Christine Zonzon, aborda a Capoeira Angola como campo em que se estabeleceu a discussão em torno da herança cultural africana na Bahia. Considerando também a legitimação dessa tradição em termos nacionais, o texto promove uma reflexão sobre a emblematicidade da Capoeira como manifestação cultural que configura e constitui historicamente um modo de ser baiano.

O capítulo 5, Musique baianaise? Representações da Bahia e do Brasil entre produtores musicais franceses, de Luciana Vasconcelos, estuda as concepções acerca da música baiana e brasileira no universo dos produtores culturais franceses, salientando alguns ícones que transversalizam as imagens da Bahia e do Brasil, configurando uma marca musical consolidada no mercado artístico europeu.

Finalmente, o capítulo 6, Axé Music - mitos, articulação e world music, de Armando Alexandre Castro, discute o processo de estabelecimento da marca Bahia no mercado musical, tanto fonográfico como espetacular, através do sucesso da axé music. Coloca em questão alguns lugares comuns em torno deste estilo musical, afirmando sua importância no processo de recriação da tradição musical baiana em termos contemporâneos sem elidir sua dimensão empresarial.

Estes textos, correspondendo a pesquisas desenvolvidas em diversos ambientes da Universidade Federal da Bahia, oferecem um painel provocativo sobre a tensão entre a sociedade baiana e o contexto mundial em que se insere. Convidamos o leitor a participar da discussão. Boa viagem. 


\section{REFERÊNCIAS}

GÂNDAVO, Pero de Magalhães. Tratado da Terra do Brasil: história da Província de Santa Cruz. Belo Horizonte: Itatiaia; São Paulo: Ed. da Universidade de São Paulo, 1980.

MARQUES, Xavier. O feiticeiro. 3. ed. São Paulo: GRD; Brasília: INL, 1975 .

MATOS, Gregório de. Pondo os olhos primeyramente na sua cidade conhece que os mercadores são o primeyro móvel da ruína, em que arde pelas mercadorias inúteis, e enganosas. In: AMADO, James (Org.). Obra poética. 4. ed. Rio de Janeiro: Record, 1999.

SALVADOR, Frei Vicente do. História do Brasil 150o-1627. 7. ed. Revisão Capistrano de Abreu, Rodolfo Garcia e Frei Venâncio Willeke, OFM; apresentação Aureliano Leite. Belo Horizonte: Itatiaia; São Paulo: Ed. da Universidade de São Paulo, 1982.

SOUZA, Gabriel Soares de. Tratado descritivo do Brasil em 1587. 9. ed. rev. e atual. Apresentação de Leonardo Dantas Silva. Recife: Fundação Joaquim Nabuco; Massangana, 2000.

VIEIRA, Antônio. Carta ao geral da Companhia de Jesus. In: PÉCORA, Alcir. (Org.). Escritos históricos e políticos. São Paulo: Martins Fontes, 1995. 


\section{Olhares estrangeiros}

impressões dos viajantes acerca da Bahia no transcurso dos oitocentos

OLÍVIA BIASIN 


\section{VIAJANTES-AUTORES NA BAHIA OITOCENTISTA}

Ao longo do século XIX, mais especificamente, depois que os portos brasileiros foram franqueados à navegação e ao comércio exterior, viajantes procedentes de diversos países e com diferentes objetivos - comerciantes, religiosos, militares, naturalistas, artistas, médicos, educadores, contrabandistas e mesmo aventureiros - instalaram-se temporariamente ou tiveram uma breve estada em Salvador. Muitos desses visitantes deixaram registros escritos de variados aspectos da cidade, relacionados tanto às paisagens naturais e urbanas como aos usos e costumes da sua gente.

Para a elaboração deste capítulo, foram analisados sete relatos de viagem produzidos por visitantes estrangeiros que estiveram na Bahia durante o período imperial (1822-1889), com exceção da inglesa Maria Graham, que esteve em Salvador, pela primeira vez, em meados de 1821, antes de a Independência ter sido declarada.

Maria Graham deixou a Inglaterra com destino à América do Sul a bordo da fragata Doris, comandada por seu marido, 
Thomas Graham, capitão da Marinha Real Inglesa. No Brasil, o navio aportou primeiramente em Pernambuco, deslocando-se em seguida para Salvador, onde permaneceu por cinquenta e três dias, dirigindo-se então ao Rio de Janeiro. Seu marido veio a falecer em 1822, a caminho do Chile. Após um ano, na condição de viúva, retornou ao Brasil e manteve estreito contato com a Família Real, desempenhando por um curto período a função de preceptora da princesa D. Maria da Glória. A viajante inglesa era escritora e já havia publicado alguns livros antes de empreender a viagem. $\mathrm{O}$ diário contendo suas vivências e impressões acerca do Brasil foi editado pela primeira vez em 1824, na Inglaterra.

O inglês Charles Robert Darwin, naturalista ainda jovem e inexperiente, participou da comissão científica chefiada pelo capitão Fitz Roy, que pretendia dar a volta ao mundo a bordo do navio Beagle. A expedição, que durou cerca de cinco anos, de 1831 a 1836, passou pela América do Sul e pelas ilhas do Pacífico. A primeira edição do seu diário de viagem foi publicada em 1839 , como pertencente ao terceiro volume da série organizada por Fitz Roy (diário esse também publicado separadamente pelo mesmo editor). Após a viagem, na qual coletou grande quantidade de material, organizou as ideias contidas na obra que o consagrou, “A origem das espécies", de 1859.

O missionário metodista norte-americano Daniel Parish Kidder, na companhia da sua esposa, permaneceu no Brasil entre os anos de 1836 e 1840, percorrendo quase todas as províncias, a fim de expandir sua religião. As anotações foram publicadas em dois volumes, no ano de 1845; o primeiro abordando sua estada em São Paulo e no Rio de Janeiro, e o segundo, relatando as observações acerca das províncias do norte.

O francês Conde de Suzannet empreendeu uma viagem com duração de seis anos ao Oriente Próximo e à América Latina, motivado pela curiosidade, aventura e desejo de completar sua 
educação. Permaneceu no Brasil de 1842 a 1843, ficando algumas semanas na Bahia, no último ano. Seu diário foi publicado pela primeira vez em Paris, em 1846.

O médico alemão Robert Avé-Lallemant residiu no Brasil por dezessete anos, de 1837 a 1855. Nesse período, exerceu a medicina no Rio de Janeiro, tendo trabalhado na Santa Casa de Misericórdia e atuado no combate à febre amarela. Regressou à Europa em 1855, mas retornou ao Brasil no ano de 1858, recomendado por Humboldt para ser médico de bordo da fragata Novara, que faria uma viagem de circunavegação. Todavia, abandonou a expedição e, após conseguir uma ajuda de custo do imperador D. Pedro II, seguiu sozinho para uma viagem ao sul do país. Depois partiu para a Bahia, onde já havia estado em 1855. Ao fim de suas excursões, retornou à Alemanha, local em que publicou as descrições das suas andanças pelo sul e pelo norte do Brasil.

Com a intenção de descansar e fugir do inverno europeu, o Arquiduque Ferdinand Maximilian von Habsburg, mais conhecido como Maximiliano da Áustria, decidiu organizar uma viagem de estudos e recreio ao Brasil. Aos 27 anos de idade, chegou ao país pela Bahia, a bordo da corveta austríaca Elizabeth, em janeiro de 1860. Maximiliano - sobrinho de D. Maria Leopoldina, primeira imperatriz do Brasil - registrou suas impressões acerca das viagens às cidades da Bahia e Ilhéus, organizadas em dois volumes. Ambos os livros foram publicados como manuscritos em Viena, nos anos de 1861 e 1864, respectivamente.

O naturalista suíço naturalizado norte-americano Jean Louis Rodolphe Agassiz visitou o Brasil de 1865 a 1866, juntamente com sua esposa, Elizabeth, e a comitiva científica que chefiou, composta de aproximadamente quinze pessoas. O célebre naturalista se interessava primordialmente por pesquisas no campo da Paleontologia, Geologia e Zoologia. Elisabeth Agassiz registrava as aventuras do casal e os resultados dos trabalhos que seu marido 
lhe fornecia diariamente, de modo que os registros foram feitos pelos dois. A obra foi publicada pela primeira vez em 1868, mas ganhou várias edições subsequentes.

Muitos viajantes que estiveram na Bahia dos oitocentos, a exemplo dos supracitados, publicaram suas impressões acerca das experiências vividas. As obras foram produzidas em forma de diários, cartas, memórias, crônicas etc., não havendo um padrão definido entre elas. Uma das maneiras de difundir a realização das viagens era por meio dos relatos que as descreviam, de modo que esse subgênero literário alcançou grande popularidade no período.

Vários estrangeiros vieram ao país com a intenção prévia de escrever sobre a experiência da viagem para publicá-la. O gênero de aventura estava em voga na Europa e os jornais e as editoras se interessavam pelos relatos de viagem, pois havia grande interesse por parte do público nesse tipo de literatura. De acordo com Augel (1980), muitas vezes, a produção literária mesclava o interesse acadêmico-científico com a intenção de difundir e legitimar o expansionismo econômico e político-militar de países europeus, especialmente da Grã-Bretanha, ou tinha o intuito de fornecer informações a respeito da imigração europeia. Como nos mostra Chartier (1990), uma obra literária é sempre produtora de sentidos e significações, podendo ser encarada como objeto de manipulação de diversos agentes, tais como editores e autores.

A maioria dos relatos tinha um caráter mais ou menos científico. Mesmo os viajantes que não eram "homens da ciência" normalmente possuíam certo conhecimento sobre história natural e estavam vinculados a alguma instituição científica, como era o caso de Maximiliano da Áustria. Vale lembrar que essas viagens aconteceram no momento em que novas relações entre a Europa e a América estavam sendo delineadas, de modo que a superioridade europeia passou a ser sustentada pelo poder de um saber 
científico e os valores universais de civilização resultaram em novas formas de imperialismo. De acordo com Silveira (2000, p.102), a ciência, então em processo de afirmação, tornava-se "território privilegiado" para a legitimação da supremacia europeia em relação aos demais povos.

Quanto aos autores das narrativas, deve-se observar que esses personagens nem sempre pertenciam à mesma classe social, possuíam os mesmos objetivos e nível de instrução, resultando daí uma heterogeneidade de interpretações e juízos de valor. Além disso, como os visitantes não se integravam à sociedade local, já vinham ao Brasil com uma ideia preconcebida sobre o lugar. Muitos também tinham dificuldade para entender o idioma e mantiveram um contato mais próximo apenas com estrangeiros ou indivíduos com costumes "europeizados". Os dados apresentados nem sempre eram confiáveis, tendo sido coletados de várias maneiras: através da observação ou do contato direto com a população, da tradução de um intérprete e de informações presentes em livros e mapas. Assim, diversos viajantes escreveram sobre as cenas, paisagens e fatos observados sem contextualizá-los, o que acarretava generalizações e imagens distorcidas.

Em contrapartida, por terem vindo de outros países e pertencerem a outras culturas, os viajantes podiam fornecer informações a respeito de práticas muitas vezes consideradas irrelevantes para os habitantes da terra, tidas como comuns e "naturais", ganhando outra leitura ante o olhar estrangeiro.

Os relatos de viagem ajudaram a criar uma imagem de Brasil para os próprios brasileiros, através das descrições da constituição racial do povo e dos seus costumes, da geografia, do clima e da vegetação, posto que, nesse período, as configurações físicas e humanas do país ainda eram pouco conhecidas. Entretanto, a principal preocupação dessa análise não é conferir se as descrições da cidade e dos habitantes condiziam com a realidade, mas 
sim indicar as impressões referentes ao "outro", construtoras de representações sociogeográficas do lugar.

\section{O CENÁRIO NATURAL}

A cidade do Salvador, desde o início da colonização portuguesa, tem despertado a atenção das principais nações do Ocidente. Situada em uma das extremidades da Baía de Todos os Santos, sobressaía-se enquanto local privilegiado para a observação da natureza e dos homens, tanto por ser uma localidade portuária como pelo clima, rica vegetação tropical, arquitetura e pluralidade étnico-cultural.

Antes mesmo de chegar à Bahia, a maioria dos viajantes já havia tido notícias dessa paragem tropical, fosse apenas de "ouvir falar", por meio de livros de história ou da leitura de algum relato de viagem. Ainda assim, é notável o impacto que a cidade, vista do mar, causava nesses estrangeiros recém-chegados. Em 1821, a inglesa Maria Graham (1956, p. 144), vinda de Pernambuco, relatou embevecida:

Esta manhã, ao raiar da aurora, meus olhos abriram-se diante de um dos mais belos espetáculos que jamais contemplei. Uma cidade, magnífica de aspecto, vista do mar, está colocada ao longo da cumeeira e na declividade de uma alta e íngreme montanha. Uma vegetação riquíssima surge entremeada com as claras construções e além da cidade estende-se até o extremo da terra, onde ficam a pitoresca igreja e o convento de Santo Antônio da Barra. [...] O pitoresco dos fortes, o movimento do embarque, os morros que se esfumam a distância, e a própria forma da baía, com suas ilhas e promontórios, tudo completa um panorama encantador; depois, há uma fresca brisa marítima que dá ânimo para apreciá-lo, não obstante o clima tropical. 


\section{A majestosa natureza constituía o centro das atenções, sendo} o elemento que tornava o Brasil imponente diante do mundo, conforme declarou o Arquiduque Maximiliano de Habsburgo (1982, p.69), ao chegar a Salvador:

Sob o rico e dourado esplendor solar dos trópicos e um reluzente céu azul, chegamos, às 10 horas, de coração alegre, à grande e extensa Bahia de todos os Santos. Foi um desses momentos felizes em que, no sentido mais lato da palavra, se nos abre um mundo novo, quando desejaríamos ter cem olhos para observarem as maravilhas desconhecidas que se nos revelam ininterruptamente e de todos os lados; um desses momentos em que, em meio à alegria, surge o pesar de não percebermos tudo, de não gravarmos tudo na memória. Embora a alma, infelizmente, desfrute do rico panorama apenas de maneira fugaz, a descrição do mesmo, através da palavra escrita, contudo, é somente uma pálida fotografia, que, apesar de calcada na verdade, se torna, no entanto, descorada e inexpressiva, quando comparada à natureza. Isso se confirma tanto melhor num novo continente, onde só a natureza impera com seu luxo incontido, onde nada que foi criado pela mão do homem, nada concluído, desperta a atenção do viajante.

Na capital baiana, o naturalista Darwin ([19--], p. 4), então com 23 anos, também não deixou escapar a emoção ao entrar em contato com os trópicos:

Mas 'delícia' é termo insuficiente para exprimir as emoções sentidas por um naturalista que, pela primeira vez, se viu a sós com a natureza no seio de uma floresta brasileira. A elegância da relva, a novidade dos parasitos, a beleza das flores, o verde luzidio das ramagens e, acima de tudo, a exuberância da vegetação em geral, foram para mim motivos de uma contemplação maravilhosa. O concerto mais paradoxal de som e de silêncio reina à sombra dos bosques. Tão intenso é o zumbido dos insetos que pode perfeitamente ser ouvido de um navio ancorado a centenas de metros da praia. Apesar disso, no recesso 
íntimo das matas, a criatura sente-se como que impregnada de um silêncio universal. Para o amante da história natural, um dia como este traz consigo uma sensação de que jamais se poderá, outra vez, experimentar tão grande prazer.

Passeando pelos arredores da cidade, o médico Avé-Lallemant (1961, p. 28) observou com acuidade as árvores tropicais, arriscando nomear cientificamente algumas delas:

Por tôda a parte acompanha-os, característico essencial, inevitável, a abundante e viçosa vegetação de palmeiras, bananeiras, artocarpos, figueiras, caricáceas e gutíferas, para não falar numa infinidade doutras plantas que, menores, pertencem às famílias das apocíneas, solâneas, asclepiádeas, passiflóreas, malpighiáceas, etc. Uma flora da Bahia não fica certamente esgotada com isso.

O Dique, suntuosa lagoa cercada por uma rica vegetação tropical, foi um dos pontos mais visitados pelos estrangeiros. Para Avé-Lallemant (1961, p. 26) reinava "ali a Natureza indômita". Por sua vez, Maria Graham (1956, p. 156) passeou a cavalo pelas suas margens, "decididamente a mais bela paisagem dêste belo país [...]". No decorrer do século XIX, naturalistas e aventureiros acorriam ao local para coletar plantas e sementes e praticar a caça de aves e insetos.

O Arquiduque Maximiliano possuía um amplo e difuso conhecimento sobre o ambiente natural. Ao realizar seu desejo de vir ao Brasil, tornou seu passeio uma aventura romântica com "um quê" de investigação científica. No Dique, o nobre austríaco registrou, mais uma vez, a exuberância da natureza baiana:

Voltamos, novamente, ao caminho aberto da mata, cuja beleza e riqueza me levaram à convicção de que os teólogos quebraram a cabeça, em vão, quanto à natureza do Paraíso perdido. Para que refletirem tanto, se os próprios olhos podem informá-los? Se eles fizessem um único passeio pela mata virgem brasileira, não mais poderiam 
duvidar de como era o Paraíso. Sob um céu como esse, cercado do aroma de plantas como essas, numa paz verde como essa, viveu pai Adão livre e à vontade, na época da sua felicidade, sem anseios e sem casaca. (HABSBURGO, 1982, p. 144)

Nos oitocentos, a visão edênica ainda persistia. Deus, liberdade e paraíso eram imagens que povoavam o universo mental desses aventureiros que, simultaneamente, louvavam o progresso material e a liberdade em meio ao ambiente natural.

Juntamente com o dique, um horto botânico, denominado Passeio Público, construído em 1810, no governo do Conde dos Arcos, tornou-se uma área de lazer bastante frequentada pelos viajantes. O missionário religioso Kidder (1943, p.34) assim o descreveu:

Êsse logradouro está situado no ponto mais amplo e mais alto da cidade. De um lado avista-se o mar, de outro a baía, e apenas uma leve grade de ferro protege o público à borda do enorme precipício que circunda o Passeio. Quanto à ventilação, nem as baterias de Nova York lhe podem ser comparadas, e a soberba eminência sôbre a qual se assenta o Passeio Público dá-lhe indiscutível superioridade sôbre aquela paragem norte-americana. O sítio destinado às baterias, nos Estados Unidos, é mais amplo e disposto com mais gôsto. Todavia, a riqueza do arvoredo e das flores do Passeio Público da Baía compensa fartamente as falhas que possa ter nos pontos acima referidos.

Também fez referência ao Passeio o Arquiduque Maximiliano de Habsburgo (1982, p. 71), escrevendo que

Entre a Vittória e as casas da cidade encontra-se, num terraço elevado, como que sustentado pelas copas das árvores situadas abaixo, o célebre Passeio Público, com seu obelisco ${ }^{1}$ e suas estátuas de mármore luzidio, sob gigantescas árvores.

1 Obelisco comemorativo da chegada de D. João VI ao Brasil, em 1808. Atualmente, o monumento encontra-se no Jardim Suspenso, em frente ao Palácio da Aclamação. 
Além de visitarem áreas mais centrais e movimentadas, muitos viajantes se arriscavam a excursionar pelos arrabaldes da cidade, optando por pontos considerados belos, aprazíveis ou pitorescos, como Bonfim, Monte Serrat, São Lázaro e Rio Vermelho.

Nas grandes cidades europeias e norte-americanas, prevaleciam as paisagens urbanas, enquanto em várias localidades do Brasil, a exemplo de Salvador, ainda era possível contemplar a grandiosidade da natureza, que não precisava de adornos para ser sublime! Ao referir-se à "mata virgem que avassala o espírito", Maximiliano de Habsburgo (1982, p.105) exclamou:

São Pedro ou o Palácio do Louvre podem ser fotografados. O escritor pode reconstituir para o leitor curioso, em ordem matemática, pedra por pedra, coluna por coluna; pode indicar as cores da construção ou mencionar quem vive ou viveu lá. Mas nem a fotografia da mata brasileira - da qual possuo fracas tentativas - nem a descrição podem oferecer ao forasteiro qualquer imagem satisfatória. Faltam às duas uma escala de comparação e pontos de referência em relação à pátria. Quem quiser ter uma idéia disso, nada mais lhe resta senão fazer as malas e viajar para cá.

Para o estrangeiro, as obras produzidas pelo homem não possuíam grande valor de atração. Afinal, nenhum naturalista ou viajante em busca de aventura deixaria sua pátria em direção ao Brasil com o objetivo de conhecer suas paisagens urbanas, uma vez que seus países de origem serviam de referência nesse quesito.

Deve-se lembrar de que, nos trópicos, não se perde a exuberância selvática da natureza, nem mesmo nas vizinhanças das grandes cidades; pois a vegetação natural ultrapassa muitíssimo, pelos efeitos pitorescos, a obra artificial do homem.(DARWIN, [19--], p.129)

Desse modo, a natureza e o componente humano - representado na figura do selvagem - constituíam as fontes de maior 
interesse, o que pode ser observado na fala do nobre austríaco, durante sua permanência na Bahia:

Mas o que se deve levar do Brasil? A arte, não floresce;
indústria, igualmente pouco. Portanto, a natureza viva e
morta tem que servir para tudo. Se tivéssemos querido
negociar inteiramente dentro do espírito brasileiro, tería-
mos sido instruídos a comprar, sobretudo, escravos. Tive
até, por um momento, a idéia de levar para a pátria uma
negrinha como surpresa original, mas, refletindo na dife-
rença de clima e nas tristes conseqüências que o mesmo
poderia ter para a saúde da criança, pensei em algo me-
lhor (HABSBURGO, 1982, p. 200)

Embora seja possível apreender certa ironia na fala de Maximiliano de Habsburgo (quando o autor considerou a possibilidade de "negociar dentro do espírito brasileiro"), não se pode deixar de notar que ele percebeu o "outro" - nesse caso, o negro - como um atrativo local, tendo em vista a possibilidade de levá-lo para seu país como um souvenir, exemplar do que havia de mais típico do país e que poderia ser facilmente transportado. $\mathrm{O}$ visitante anulou por completo a identidade do indivíduo, comparando-o a um produto, coisificando-o. No entanto, posteriormente, percebeu o "outro" como ser dotado de humanidade e se desfez da ideia inicial, optando por levar uma coleção de animais - macacos e papagaios - como lembrança de viagem.

\section{ASPECTOS URBANOS E DINÂMICA CITADINA}

A cidade do Salvador - sede do governo colonial português até 1763 - foi construída sobre uma escarpa seguindo em declive para o mar, estendendo-se por terreno irregular contíguo. Ao redor da Baía de Todos os Santos ou em suas proximidades, ademais de Salvador, foram fundados os municípios de Nazaré, Maragojipe, 
Cachoeira, Santo Amaro e São Francisco do Conde, entre outros que compõem a região denominada Recôncavo Baiano, onde prosperou uma das mais importantes economias canavieiras das Américas e ergueu-se um dos mais expressivos conjuntos arquitetônicos de estilo barroco do país.

Na primeira metade do século XIX, Salvador era o segundo centro urbano de maior relevância do Brasil, estando atrás apenas do Rio de Janeiro. Os negros e os mestiços representavam uma maioria de aproximadamente $72 \%$ da população. Mattoso (1992) estima que, entre 1810 e 1870 , o número de habitantes da cidade oscilou entre 50 mil e 100 mil; na última década, no ano de 1890, estaria em torno de 145 mil habitantes. A maior parte da população de Salvador era muito pobre, composta, em sua maioria, por escravos. A riqueza estava concentrada nas mãos de poucos, entre eles, muitos estrangeiros.

Salvador caracterizava-se pela configuração acidentada do terreno onde foi construída, dividindo-a em Cidade Alta e Cidade Baixa. Nos oitocentos, a ligação entre os dois pontos se fazia por escadarias e principalmente por ladeiras, que os mais abastados costumavam subir e descer dentro de "cadeirinhas de arruar" carregadas por escravos. Cavalos, burros e mulas também transitavam pela cidade transportando pessoas e mercadorias.

Os primeiros transportes coletivos de Salvador, as gôndolas (grandes carruagens puxadas por animais) e os bondes puxados por burros, começaram a circular a partir da segunda metade do século. $\mathrm{O}$ valor das passagens era inacessível à maior parte da população, que continuava a se locomover a pé, enquanto os ricos seguiam dando preferência às cadeirinhas, que eram mais baratas e faziam parte de um hábito arraigado na sociedade.

No ano de 1873 , foi inaugurado pelo comerciante e Comendador Antônio de Lacerda o Elevador Hidráulico da Conceição, posteriormente rebatizado como Elevador Lacerda, estabelecendo 
um novo elo entre os dois níveis da cidade. Para transportar cargas de um plano a outro também eram utilizados guindastes, que funcionaram do final do século XVI até, possivelmente, meados de 1870.

Inaugurados em finais dos oitocentos, o Plano Inclinado Gonçalves, construído no local do antigo guindaste dos Padres, na freguesia da Sé, e o plano inclinado do Pilar, construído onde séculos antes havia funcionado um dos primeiros guindastes de Salvador, na freguesia de Santo Antônio Além do Carmo, também foram importantes para a dinamização do circuito comercial da cidade. (SAMPAIO, 2005)

A viajante Maria Graham teve a oportunidade de se locomover através das cadeirinhas de arruar, meio de transporte mais usado na cidade.

Chovia quando desembarcamos. Por isso, como as ruas que conduzem para fora da imunda cidade baixa não permitem o emprêgo de veículos de roda, em virtude da violência da subida, alugamos cadeiras e as achamos, se não agradáveis, ao menos cômodas. [...] Tudo é suspenso pelo alto por um único varal, pelo qual dois negros a carregam a passo rápido sôbre os ombros, mudando, de vez em quando, do direito para o esquerdo. (GRAHAM, 1956, p.145)

A cidade estava dividida administrativamente em dez freguesias urbanas. Cada uma delas encontrava-se ligada a sua igreja matriz, o que mostra a densa ligação existente entre política, poder eclesiástico e sociedade. O comércio se concentrava na Cidade Baixa, nas freguesias de Nossa Senhora do Pilar e, sobretudo, na de Nossa Senhora da Conceição da Praia, área portuária.

No porto da cidade, um dos mais movimentados do país, eram realizadas intensas atividades comerciais com a Europa e outros continentes. Próximo a ele, uma gama de produtos destinados à exportação, como madeira, açúcar, algodão, fumo, cachaça, azeite 
de baleia, café, cacau e couro, era armazenada nos trapiches. Por sua vez, importava-se grande variedade de mercadorias vinda da Europa, principalmente de Portugal e da Inglaterra: artigos industrializados, utensílios domésticos, perfumaria, instrumentos musicais, tecidos, louças, calçados, barris de cerveja, caixas de vinho, de manteiga, de azeite doce e bacalhau.

O comércio de escravos foi uma lucrativa atividade na pauta comercial da província desde o século XVI. A sociedade baiana do período manteve profundas relações escravistas na sua composição, que permeavam não só as atividades econômicas, como todos os aspectos da vida social. Em Salvador, funcionava o maior mercado de escravos do Norte. Negros recém-chegados da África eram expostos nas portas dos armazéns para serem vendidos ou alugados, cena que deixou muitos estrangeiros perplexos. Ao constatar o intenso comércio realizado na Cidade Baixa, com suas variadas lojas e mercadorias, Maria Graham (1956, p. 150) notou que os escravos também figuravam como um dos artigos expostos à venda.

[...] aí estão os mercados que parecem estar bem sortidos, especialmente de peixe. Aí fica também o mercado de escravos, cena que ainda não aprendi a ver sem vergonha e indignação. Adiante fica uma série de arcadas com lojas de ourives, joalheiros e de armarinhos e suas mercadorias miúdas.

Situavam-se na Cidade Baixa dois grandes e diversificados mercados, destacando-se o de Santa Bárbara, onde se vendiam frutas, frutos do mar, pedras preciosas e animais, entre outros itens. O passeio de Maximiliano de Habsburgo (1982, p.138) por um "mercado de frutas" fora "muitíssimo gratificante". Descreveu-o de forma bastante viva: "Para o viajante europeu, o mercado de frutas da Bahia tem uma importância realmente científica, como um rico mostruário dos produtos mais característicos da terra, reunidos num só local”. 
Comparou-o ao bazar do Cairo, ao mercado de Gibraltar e ao de London Bridge. No entanto, considerou que faltava ao mercado de Londres "aquela característica peculiar e exótica" encontrada no da Bahia.

Aglomeravam-se nas ruas e no cais negras vendendo objetos africanos, tecidos e diversos tipos de alimentos como peixes, frutas, mingaus e bolos. Muitas dessas mulheres estavam trabalhando para suas senhoras, das quais normalmente ganhavam alguma recompensa financeira. Com o dinheiro acumulado no decorrer de anos de trabalho, muitas delas conseguiam comprar sua carta de alforria, comumente paga à prestação. Vender era o ofício mais exercido na Bahia dos oitocentos, havendo comerciantes de status e níveis sociais diversos.

Os barbeiros ${ }^{2}$, santeiros, serralheiros, vendedores de água, trançadores de cestos e outros tipos de trabalhadores também ofereciam seus serviços ao ar livre. Negros - escravos e libertos, carregadores de pesadas cargas ou de passageiros - costumavam ficar em movimentadas praças e esquinas, chamadas de "cantos", à espera de fregueses.

Kidder (1943, p.7) concluiu: "A cidade baixa não oferece atrativos para o estrangeiro", embora tenha registrado que as principais casas de comércio se situavam ao longo da rua da Praia e tenha elogiado a arquitetura do prédio onde ficava a Bolsa. ${ }^{3} \mathrm{Di}-$ ferentemente de Kidder (1943), o Conde de Suzannet considerou alguns prédios dignos de nota, sendo eles: a alfândega, o arsenal, os estaleiros da Marinha, a Bolsa e as igrejas de N. S. do Pilar e da Conceição. A beleza desta última também foi observada por Maria Graham (1956) e Avé-Lallemant (1961).

2 Além de fazerem a barba e cortarem os cabelos dos clientes, muitos "barbeirossangradores" ajudavam a curar os enfermos com sangrias e sanguessugas e ainda praticavam as atividades de dentista e músico.

3 O prédio da Bolsa, construído em estilo neoclássico, encontrava-se onde atualmente funciona a Associação Comercial da Bahia. 
A configuração e a sujeira da Cidade Baixa incomodaram sobremaneira Maria Graham (1956, p.145), que afirmou ter sido este "sem nenhuma exceção o lugar mais sujo em que eu tenha estado", descrevendo-o assim:

\begin{abstract}
Nos espaços que deixam livres, ao longo da parede, estão vendedores de frutas, de salsichas, de chouriços, de peixe frito, de azeite e doces, negros trançando chapéus ou tapetes, cadeiras (espécie de liteiras) com seus carregadores, cães, porcos e aves domésticas, sem separação nem distinção; e como a sarjeta corre no meio da rua, tudo ali se atira das diferentes lojas, bem como das janelas. Ali vivem e alimentam-se os animais. Nessa rua estão os armazéns e os escritórios dos comerciantes, tanto estrangeiros quanto nativos.
\end{abstract}

Os odores, a insalubridade, o descuido das vias públicas, a irregularidade das ruas e a presença dos escravos na dinâmica citadina eram aspectos da Cidade Baixa que despertavam a atenção e causavam repulsa nos viajantes.

Além de constatar que a Cidade Baixa era o centro comercial, o Conde de Suzannet (1957, p.183) também notou que na rua "estreita e comprida que corre ao longo da praia”, respirava-se “os odores mais nauseabundos”. A repugnância causada nos viajantes não era sentida da mesma maneira pelos moradores, nem mesmo pelos estrangeiros radicados na capital baiana. Afinal, os visitantes e os residentes possuíam mentalidades, sensibilidades e percepções olfativas distintas.

Em contrapartida, a Cidade Alta era considerada elegante, limpa e tranquila, local onde era possível observar belas casas, carruagens e pessoas trajadas à moda europeia. Tratava-se de uma região residencial, apesar de contar com alguns estabelecimentos comerciais de pequeno porte. A maioria dos habitantes de Salvador residia nessa área, sendo a freguesia da Sé o centro jurídico, administrativo e eclesiástico. 


\author{
Referiu-se a essa região, de forma bastante elogiosa, o Conde \\ de Suzannet (1957, p. 183):
}

A cidade alta, que se alcança subindo uma rampa íngreme, é menos freqüentada do que a cidade baixa, mas o conjunto das construções é de uma arquitetura nobre e regular, embora um pouco pesada, e merece a atenção do viajante. A Bahia é a sede do arcebispado metropolitano do Brasil. Há belos edifícios que relembram a antiga opulência: o teatro, o palácio do presidente e algumas igrejas. A maravilhosa vista da baia que se descortina do alto em que está situada a cidade completa a paisagem de maneira feliz. Os inúmeros conventos demonstram a importância religiosa da Bahia.

Ao chegar à Praça do Teatro, na parte alta da cidade, Maximiliano de Habsburgo (1982, p.87-88) verificou que:

Os prédios tornam-se mais elegantes, mais lisboetas. E já se vêem algumas fachadas, como na praia do Tejo, revestidas com azulejos. Diante das casas, onde há espaço, encontram-se pequenos terraços, nos quais algumas plantas, como roseiras e camélias, se apresentam muito graciosas, em vasos de barro, como galho de flor sobre um bolo confeitado de glacê. A Praça do Teatro é surpreendente.

Na praça do Palácio (atual Praça Tomé de Souza) estavam localizadas a Câmara Municipal e a Cadeia, o Tribunal da Relação, a Casa da Moeda e o Palácio do Governo, ocupado pelo presidente da província. Próxima à Câmara, ficava a Santa Casa de Misericórdia, composta pela igreja, pela sede desta irmandade e por um hospital de indigentes. Ao norte, estava a Matriz da Freguesia da Sé ou "Sé Velha”. Mais a frente, no Terreiro de Jesus, a Igreja dos Jesuítas (tornada Catedral Basílica) e a Escola Médico-Cirúrgica. Retornando à Praça do Palácio e seguindo em direção à rua direita do Palácio, chegava-se ao largo do famoso Teatro São João. Essas edificações eram sempre mencionadas pelos viajantes. 
Os visitantes estavam atentos aos aspectos arquitetônicos das edificações, sendo que as igrejas e conventos chamavam especialmente a atenção pela grande quantidade. Avé-Lallemant (1961, p. 23) fez alusão a algumas igrejas:

Achei realmente notável a igreja dos jesuítas no Terreiro, a Igreja do Colégio. Aí o mármore sobe até à abóbada; a igreja é suntuosa, embora não obedeça ao mais rigoroso estilo eclesiástico. Quase não lhe é inferior a pequena igreja de Nossa Senhora da Praia. E assim se aglomeram as igrejas uma após outra, muitas sem importância, merecedoras outras, em alto grau, de serem vistas e verdadeiramente admiráveis.

Quanto à estética dos equipamentos urbanos, a presença de bonitos chafarizes e fontes públicas foi citada por alguns estrangeiros. "Êsse gosto original pela arquitetura ainda hoje continua evidente na Bahia, tendo tido mesmo desenvolvimento progressivo. Basta, para prová-lo recordar aqui as belas fontes novas que se encontram na Bahia”, escreveu Avé-Lallemant (1961) na sua segunda estada em Salvador. Maravilhou-se, em especial, com a fonte localizada no Terreiro de Jesus, exclamando ser "[...] a obra-prima mais perfeita [...] cuja aquisição faz honra à cidade". Opinava que a cidade do Rio de Janeiro deveria contar com fontes semelhantes e que "os baianos deviam ir até as fontes para verem algo nobre e educarem seu senso de beleza”. (AVÉ-LALLEMANT, 1961, p. 23)

No tocante à infraestrutura urbana, toda a cidade sofria com a má pavimentação das ruas, ausência de saneamento básico e precariedade do fornecimento de água e luz. Em 1829, foram instalados lampiões a óleo de baleia, mas que não geravam uma boa iluminação. A situação só melhorou a partir da década de 1850, quando lampiões a gás foram colocados em diversos pontos. De qualquer modo, era necessário ter coragem para sair de casa após o findar do dia, visto que as ruas ficavam muito escuras. 
Na cidade, altos funcionários da administração pública e do clero, donos de engenhos e comerciantes afortunados residiam em solares e luxuosos sobrados. Por sua vez, os cônsules estrangeiros costumavam alugar casas arborizadas nos arredores. Os lojistas, os pequeno-burgueses e os artesãos possuíam humildes habitações; os soldados e os negros livres se alojavam em casebres, casas velhas assobradadas ou habitavam os andares inferiores dos sobrados que abrigavam as famílias ricas. A localização e o tipo de residência designavam a posição social da família.

Na Sé e em outras freguesias do centro - Passo, Santo Antônio Além do Carmo, Santana, São Pedro -, foram construídas simples residências, levantadas em terrenos foreiros, habitadas por famílias negras e pobres. Essas pessoas, aos poucos, começaram a afugentar os vizinhos com melhores condições econômicas, especialmente para a Vitória, uma elegante periferia ao sul da cidade, que passou a ser mais habitada a partir de 1850.

Maximiliano de Habsburgo (1982, p.112) registrou que a Vitória lhe havia cativado "decisivamente", ao fazê-lo recordar a região de Claremont, na Inglaterra. Kidder (1943, p. 37-38) relatou o quanto era aprazível, aos olhos dos viajantes, o panorama observado da Vitória.

Na verdade, poucas cidades podem apresentar uma visão de conjunto de maior beleza que a Baía, a quem observar de uma certa distância, do mar. Mesmo o Rio de Janeiro dificilmente lhe pode ser comparado. A capital do Império excede a Baia pela infinita variedade de seus lindos subúrbios; todavia, não conseguiríamos apontar lugar algum que rivalizasse com o que na Baia chamam o Morro da Vitória. [...] na Baia, porém, as vantagens parecem-se concentrar tôdas num único bairro, de modo a não deixar dúvidas, ao estrangeiro, quanto à escolha da localização de sua residência. No Morro da Vitória, encontram-se os mais belos jardins da Baía, as mais encantadoras alamedas e as mais vastas extensões de sombra. Aí se acham também, as melhores casas, o melhor clima, a melhor água e a melhor sociedade. 


\section{A BAHIA NEGRA: PLURALIDADE ÉTNICO-CULTURAL E MANIFESTAÇÕES CULTURAIS}

Não foram apenas os cenários naturais e os aspectos arquitetônicos da cidade que provocaram a admiração dos viajantes oitocentistas. Eles costumavam descrever tudo o que consideravam exótico e pitoresco, destacando-se a vida dos escravos, as relações inter-raciais e as manifestações culturais.

Os negros eram considerados diferentes do restante da população devido à sua procedência, cor da pele, caracteres fenotípicos e culturais, sendo recorrente a percepção de que eram inferiores, ideia dominante na época. É importante lembrar que foi justamente no século XIX que a origem comum da espécie humana passou a ser intensamente questionada e os homens passaram, cada vez mais, a ser hierarquizados segundo a sua "raça". No período, o debate racial ganhou força e tornou-se central no âmbito científico europeu o norte-americano.

Entretanto, apesar de o racismo científico haver se cristalizado no transcurso dos oitocentos, nem todos os cientistas aderiram a uma mesma teoria, não havendo uma homogeneidade de discurso. Nesse sentido, o debate ocorria principalmente em torno dos monogenistas, que defendiam a unidade do gênero humano, e dos poligenistas, que acreditavam que as raças teriam se originado separadamente, já biologicamente hierarquizadas. (SCHWARCZ, 2002)

Durante o século XIX, a interpretação pessimista que via o Brasil como atrasado em função da sua composição étnica era bastante difundida. Nesse momento, as teorias raciais eram priorizadas na análise dos problemas locais ${ }^{4}$. Além disso, articulavam-se os fenômenos da natureza com os caracteres dos povos de cada

4 Lilia Schwarcz (2002) mostra que tais teorias, bastante difundidas na Europa, chegaram ao Brasil tardiamente, em finais do século XIX. 
região. Assim, vai sendo delineado um certo determinismo natural que justifica o atraso encontrado nos trópicos. "Gera-se e nascese. De resto, vive-se quase como os animais da mata virgem". (HABSBURGO, 1982, p.113)

Seguindo essa perspectiva, a paisagem tropical, ao mesmo tempo em que era vista como pitoresca e exuberante, também era encarada como um obstáculo ao avanço civilizatório, havendo um posicionamento ambíguo nas falas desses atores sociais.

Enquanto passeava pela cidade da Bahia, o reverendo Kidder (1943, p. 8) discorreu o seguinte comentário acerca dos negros que observou:

Vêem-se chusmas de negros altos, atléticos, aos pares ou em grupos de quatro ou seis, transportando a carga suspensa em grossos paus. Outros tantos ficam encostados nos madeiros, tecendo palha, deitados nos passeios, dormitando pelas esquinas e dando aos transeuntes a impressão de enormes rolos de serpentes, reluzindo ao sol. Os que estão cochilando têm geralmente uma sentinela encarregada de os despertar quando procurados por algum serviço e, ao sinal combinado, levantam-se como elefantes com sua carga.

Na sua análise, o religioso comparou o negro ao animal, tanto no plano estético quanto no tipo de trabalho por ele realizado, sendo possível observar a presença da ideia de hierarquia racial entre brancos e negros.

Durante um passeio no Dique, Maximiliano de Habsburgo (1982, p.102) notou que:

Tais negros são realmente um povo de boa índole que, com sua cordialidade quase canina, reconhecem a superioridade dos brancos. Toda essa cena, com as figuras negras pré-adâmicas, às margens do regato fresco, sombreadas por mangueiras misteriosas, cercadas de grande quantidade de aroideas e milhares de outras cores cintilantes, apresentava um quadro típico do exotismo meridional. 
O nobre austríaco também animalizou os negros em suas descrições, associando-os a uma imagem primitiva e ao exotismo dos trópicos, sendo esta a representação dominante. Acreditavase que tais grupos estivessem na infância da humanidade. Essa consideração estava afinada com o discurso acadêmico baseado em estudos comparativos e classificatórios do século XIX, tais como a influência do clima nas características dos povos e a existência de estágios na história da civilização.

Segundo Silveira (2000), tanto a animalização quanto a infantilização das raças consideradas inferiores eram argumentos comumente usados pelos intelectuais dos oitocentos. As correntes do pensamento racialista naturalizavam os modos de pensar e agir, transformando o comportamento a algo inato ao tipo físico e excluindo os processos históricos e psicossociais que permeiam a vida dos indivíduos. Na associação da raça com a personalidade, a pretensa supremacia moral e intelectual do branco europeu era sempre destacada.

Nesse sentido, o reconhecimento da alteridade dava margem à hierarquização, baseada principalmente nas diferenças físicas entre os indivíduos e na tecnologia, atrelada à ideia eurocêntrica de progresso.

Apesar de a maioria dos visitantes depreciar os homens de cor, em Salvador, o Conde de Suzannet (1957, p.184) considerou a população negra "robusta e ativa” e impressionou-se com “[...] a beleza das negras que se vêem voltando das fontes situadas fora da cidade, com o cântaro elegantemente colocado à cabeça”.

Enquanto observava os negros que transportavam cargas para a Cidade Alta, Avé-Lallemant (1961, p. 20-21) comentou:

[...] quase não se pode ver mais soberba figura de homem que as dêsses negros da Bahia, sobretudo os Minas, tão comuns ali... Apertados uns contra os outros, sob o varal, êsses homens côr de azeviche formam o mais admirável 
grupo atlético que se possa ver. Põem-se em marcha aos gritos e com certo entusiasmo bélico. O suor escorre-lhes pelo corpo nu, retesam-se todos os músculos, salientes, bojudos; as partes carnudas das espáduas e a parte superior do braço são muitas vêzes idealmente belas; Miguel Ângelo não as teria esculpido mais perfeitas no mármore. E, contudo, nesse tão belo desenvolvimento de músculos, nada de exagerado. Nada me fêz lembrar, quando admirava êsses negros Minas, um Hércules de Neméia, apoiado na sua clava; tudo, ao contrário, me lembrava um Aquiles e o pugilista Polideuces.

Conforme observou Sela (2006), era recorrente a comparação dos corpos negros com personagens e metáforas greco-latinas ou neoclássicas. Esse procedimento era consequência de um interesse surgido mais fortemente no século XVIII, nas academias de belas-artes europeias, de modo que o empenho em lançar o olhar para esses modelos já estava consolidado nos oitocentos. Para os artistas, eles representavam belos espécimes viris, caracterizados pelo vigor e flexibilidade, que contrastavam com sua suposta incapacidade intelectual ou afetiva. Muitas dessas descrições também estabeleciam uma oposição entre a feiura dos rostos e a beleza e robustez dos corpos. Quando os viajantes faziam alusão à força muscular e às formas corporais dos negros, os carregadores eram os sujeitos mais citados.

Avé-Lallemant (1961, p. 21-22) admirou-se também com a beleza das mulheres negras Minas ${ }^{5}$, associando sua imagem à sensualidade.

As mulheres negras da Bahia parecem mais bonitas que os negros. Como tais, já se tornaram realmente famosas. E de fato quase não se pode encontrar em outra parte maior

5 Segundo João Reis (2003), a imprecisa designação Mina abarcava nagôs, jejes, haussás e outros grupos étnicos oriundos do golfo do Benin, atual República do Benin, e parte da Nigéria. A denominação Mina não era homogênea, já que as nações africanas da escravidão eram identidades construídas mais com base na diáspora do que nos códigos étnicos vindos da África. 
riqueza de formas que entre as negras Minas da Bahia. [ ...] Entre as negras Minas moças da Bahia vêem-se ou adivinham-se formas admiráveis. Além disso, têm tôdas porte soberbo, ombros bem inclinados para trás, de maneira que o peito se salienta fazendo os pomos parecerem muito mais desenvolvidos. Nesse porte exagerado há, sem dúvida, uma espécie de provocação [...] Movem, inquietas, os ombros e os braços e têm um modo peculiar de balançar os quadris [...] Há muitas negras Minas livres na Bahia, e estas, ao que parece, têm perfeita consciência dos seus escuros encantos. Não notei nenhuma negra vestida à européia, o que, na verdade, a teria transformado em macaca.

Após deleitar-se ante a observação desses homens e mulheres, o autor se retratou, apresentado esse quadro como a face obscura da cidade. "Essas múltiplas figuras de negros, modificando-se e movimentando-se misturadas, é que dão à cidade êsse tom africano e constituem, por certo, o seu lado sombrio, o seu lado escuro". (AVÉ-LALLEMANT, 1961, p. 22)

De acordo com Maximiliano de Habsburgo (1982, p. 81), em geral, os negros nada possuíam de atrativo e belo; contudo, esses sujeitos não deixaram de ser por ele apreciados:

No muro do jardim, ao longo do passeio, mulheres negras, de cócoras, vendiam frutas. Um grupo bastante interessante para o recém-chegado, no qual todos os tamanhos, idades e proporções estavam representados, através dos exemplares mais originais.

Ao avistar uma jovem negra vestida com uma indumentária tipicamente africana - saia de chita, bata branca, xale colorido, turbante e contas de vidro -, o nobre austríaco encantou-se com admirável figura e afirmou que, em se tratando de negras com tal aspecto, "o coquetismo era possível”. (HABSBURGO, 1982, p. 82)

Essas características ambivalentes concedidas aos negros, ora positivas, ora negativas, situavam-se num jogo de representações 
que se movimenta e se modifica a depender das circunstâncias e do lugar de quem as constroem. Joffe (1998) diz que "o outro" nãoeuropeu era visto de forma depreciada, mas também se tornava desejável por desafiar os valores centrais da sociedade eurocêntrica, significando uma ameaça às suas normas. ${ }^{6}$

Nesse sentido, as populações negras ou indígenas, ao mostrarem a existência de outras crenças e valores, mais associados à emoção e à espiritualidade, despertavam repulsa, mas também fascínio. No caso da negra brasileira, a ênfase era ainda maior devido a sua condição de mulher, historicamente carregada de simbolismos, relacionados à degradação e ao desejo.

A maciça presença da população negra que circulava pelas ruas da cidade surpreendia aos visitantes, que tinham referências estéticas bastante padronizadas e limitadas. Quando consideravam o negro belo, vacilavam quanto a essa percepção, ficando confusos em relação aos seus parâmetros de beleza e vendo-o como bonito porque exótico ou sensual.

Apesar de alguns visitantes perceberem as diferenças étnicas entre os africanos, em geral, referiam-se à raça negra como uma unidade, englobando todos os negros numa mesma categoria, caracterizando-os pelos aspectos físicos e morais. Assim, criavam generalizações e passavam a impressão de que, independentemente da procedência, condição econômica e hierarquia entre africanos e crioulos (negros nascidos no Brasil), compartilhavam os mesmos espaços, valores e códigos.

A respeito da presença dos negros no cotidiano da cidade, Avé-Lallemant (1961, p. 20) se pronunciou da seguinte maneira:

Quando se desembarca na Bahia, o povo que se movimenta nas ruas corresponde perfeitamente à confusão das casas e vielas. De feito, poucas cidades pode haver tão ori-

6 A autora ressalta que conceder ao "outro" características negativas e ao mesmo tempo vê-lo como atraente é comum também em culturas não hegemônicas. 
ginalmente povoadas como a Bahia. Se não soubesse que ela ficava no Brasil, poder-se-ia tomá-la, sem muita imaginação, por uma capital africana, residência de poderoso príncipe negro, na qual passa inteiramente despercebida uma população de forasteiros brancos puros. Tudo parece negro: negros na praia, negros na cidade, negros na parte baixa, negros nos bairros altos. Tudo o que corre, grita, trabalha, tudo o que transporta e carrega é negro.

O universo do trabalho era a situação mais comum na qual os viajantes representavam os homens de cor. Em julho de 1865, após chegarem à Bahia e se acomodarem na casa de campo de Antônio de Lacerda, os Agassiz (1975, p. 93) tiveram a oportunidade de contemplar "os negros que, com um cesto de verduras ou de flores e frutos na cabeça, vão e vêm no serviço da casa”.

Maximiliano de Habsburgo (1982, p. 86), embora tenha considerado a população baiana "peculiar", opinou que não havia um tipo característico que pudesse representar o povo:

Também aqui, a população é peculiar. Vêem-se negros e mais negros. [...] Os senhores de escravos, ao contrário, são brancos, ou melhor, amarelo-pálidos. Faltam aqui tipos característicos, como nas cidades da África e da Ásia. Isto porque o povo primitivo foi impelido para as matas mais profundas.

Contudo, ao contrário do nobre austríaco, o casal Agassiz julgou que a junção dos aspectos mais peculiares da cidade da Bahia, entre os quais se encontravam os negros, oferecia uma feição à nação.

Quando se chega pela primeira vez à América do Sul, é na Bahia que se devia aportar. Nenhuma outra cidade manifesta em tão alto grau o caráter, reproduz tão visivelmente a fisionomia, leva a grau tão acentuado a marca da nação a que pertence. Limitamo-nos esta manhã a atravessar a cidade e dela só poderíamos dizer bem pouca coisa, mas vimos o bastante para confirmar tudo o que se narra da 
originalidade e do pitoresco de seu aspecto. Ao desembarcar, achamo-nos ao pé de uma colina quase perpendicular; acorreram negros oferecendo-se para nos transportar ao alto dessa encosta escarpada e inacessível aos veículos, numa 'cadeira', espécie de assento encoberto por compridas cortinas. É um estranho meio de transporte para quem nunca o experimentou e a cidade em si, com suas ruas em precipícios, suas casas bizarras, suas velhas igrejas, é tão estranha e tão antiga como esse veículo singular. (AGASSIZ e AGASSIZ, 1975, p. 94)

Assim, sob a ótica do casal, o exotismo da população de cor, juntamente com o cenário da cidade do Salvador, dava o tom da singularidade brasileira.

As manifestações culturais, tanto de caráter religioso quanto cívico, também constituíam momentos privilegiados para a observação do povo. Durante a Regência, em festa realizada no Passeio Público de Salvador, com o objetivo de comemorar o aniversário de Pedro II, o Pastor Kidder (1943, p. 35) relatou:

A riqueza, a elegância e a beleza das baianas jamais teve melhor oportunidade de se exibir que nessas noites memoráveis. Ótima ocasião para divagações filosóficas sôbre a natureza humana. Da infância irrequieta à velhice provecta, tôdas as idades, tôdas as classes e todos os caracteres encontravam-se ali representados.

Em 8 de dezembro de 1858, Avé-Lallemant (1961) presenciou os festejos em homenagem à Nossa Senhora da Conceição, padroeira do Brasil até 1930, quando foi substituída pela Nossa Senhora Aparecida. Teceu os seguintes comentários a respeito da igreja e da procissão:

O templo ostentava todo o brilho do nobre material de sua ornamentação, as variegadas pinturas do seu teto, a profusa iluminação do seu altar-mor, junto ao qual tôda a agitação daquela gente que ia e vinha, sobretudo negros, causava a mais singular impressão. Por isso a pe- 
quena procissão pareceu também uma pantomima sem ordem, e as meninas fantasiadas no cortejo, que deviam representar anjos e a Santa Virgem, lembravam fantoches de bailado ou dançarinas de corda. (AVÉ-LALLEMANT, 1961, p. 45)

O visitante demonstrou admiração pelo templo e ressaltou o seu encanto pela ornamentação; porém, os comentários sobre a procissão revelam sua perplexidade acerca dos costumes baianos. O préstito pareceu-lhe uma "pantomima sem ordem”, ou seja, uma espécie de representação em que os atores se manifestam apenas por gestos ou expressões fisionômicas, prescindindo da palavra e da música. A procissão não lhe pareceu um cortejo católico, e sim, uma encenação sem sentido cristão.

Esteve nos festejos de Nosso Senhor do Bonfim, em 12 de janeiro de 1860, o Arquiduque Maximiliano. Considerou a circunstância ideal para melhor estudar "a carne humana negra" e "os trajes dos negros". Ao chegar à colina, ficou admirado com a movimentação dos fiéis e com o comércio realizado na praça e no adro da igreja, onde "Caixas de vidros cheias de comestíveis pairavam, ousadamente, sobre a multidão" e "Pequenos grupos de fornecedores de cachaça formavam as ilhas, no mar de pessoas". (HABSBURGO, 1982, p.128)

Nem mesmo no interior da igreja o visitante encontrou um ambiente silencioso e de contrição. Foi "tomado por um arrepio de indignação" quando percebeu que em meio à desordenada festa popular o padre celebrava a missa "tranquilamente" e que "o povo tagarela era cristão batizado, assim chamados católicos, que assistiam à missa”. Opinava que "para um católico respeitável, todo esse alvoroço deve parecer blasfêmia, pois nessa festa popular dos negros, misturavam-se, mais do que o permitido, resquícios do paganismo na assim chamada romaria”, referindo-se ao evento como uma "louca bacanal". (HABSBURGO, 1982, p. 129-131) 
Por conta do ambiente descontraído no qual se desenrolava a cerimônia e do entrelaçamento entre sagrado e profano, o visitante não compreendia a associação entre o culto cristão e a festa popular. Assim, não podia conceber que o sentimento religioso fosse compatível com um festejo de rua, supondo que este sentimento não fosse a principal motivação dos fiéis.

Para os viajantes, era difícil observar as festas católicas sob o aspecto religioso, pois não compreendiam o sincretismo tão presente em tais comemorações. Criticavam a organização e a estrutura dos rituais, influenciados por uma perspectiva mais ortodoxa do catolicismo romano e, principalmente, por uma visão protestante. Nesse sentido, os eventos perdiam sua função religiosa e passavam a ser contemplados como um espetáculo, uma curiosidade local.

De fato, desde o período colonial, havia uma imbricação entre elementos europeus, indígenas e africanos nos festejos católicos, além de ingredientes carnavalescos. As homenagens aos santos foram muitas vezes comparadas às festas pagãs. Maximiliano de Habsburgo (1882, p. 130) afirmou que na igreja do Bonfim "festejavam-se as Saturnais dos negros" e comparou o agito e barulho dos devotos aos "grandes bailes da elegante sociedade de Corte de Viena [...]".

Alguns viajantes também participaram do Carnaval. A principal brincadeira desse festejo consistia em jogar farinha, água suja ou bolas de cera contendo água perfumada nos transeuntes. Essa prática possuía características menos agressivas que em Portugal e aos poucos ganhou contornos locais, principalmente devido à participação da população de cor.

Em 4 de março de 1836, Darwin conheceu o Carnaval da Bahia acompanhado de John Wickman e de Bartholomew Sullivan, oficiais integrantes da tripulação do navio Beagle. Desavisados acerca das práticas recreativas presentes na festa, o naturalista 
e seus companheiros não vivenciaram uma experiência muito agradável. Eis o seu relato:

Este é o primeiro dia do carnaval, mas Wickman, Sullivan e eu, nada destemidos, estávamos determinados a encarar seus perigos. Esses perigos consistem em ser atingidos sem misericórdia por bolas de cera cheias de água e sair encharcado por grandes seringas de lata. Achamos muito difícil manter nossa dignidade enquanto caminhávamos pelas ruas. Carlos V disse que seria um homem valente aquele que pudesse apagar uma vela com os dedos sem pestanejar; eu digo que seria (valente) quem pudesse andar com passos firmes enquanto baldes de água o ameaçassem, por todos os lados, de ser sobre eles despejados. (DARWIN, 2009, p. 3, tradução nossa)

\section{O Conde de Suzannet (1957, p. 185-186), alguns anos mais tarde, em 1843, também presenciou o Carnaval da Bahia, descre- vendo-o, possivelmente, com certa fantasia:}

A cidade tem as suas festas, os seus dias de loucura e abandono, que são o carnaval. É um estranho prazer êste carnaval da Bahia. Durante três dias, tôdas as atividades são suspensas. Na rua somos assediados por todos os lados por vasilhas de água que nos atiram à cabeça, e que machucam, molham e até ferem. Mas pode, também, acontecer que uma mulher bonita jogue sôbre você uma bola de cêra cheia de água perfumada, e então nada impede que você se embarafuste pela casa dela; pois tôdas as casas estarão então abertas. Quantas ligações não terão começado durante o entrudo7! Também os rapazes e as môças conservam com zelo especial o velho hábito do carnaval e é de crer que estas tradições galantes não acabarão tão cedo na Bahia.

7 Entrudo é o nome que se costumava dar aos folguedos de verão, de origens portuguesa e africana, muitas vezes associados nas mesmas brincadeiras. Eram assim chamadas, sobretudo, aquelas festas populares que precediam imediatamente a Quaresma, antes da institucionalização do Carnaval de acordo com o modelo mais urbano e formal que passou a ser realizado em diversas cidades do Brasil a partir do final do século XIX. 
Entre a população de Salvador, havia o gosto generalizado pela música, de modo que diversas práticas recreativas estavam ligadas às atividades musicais e à dança. As modinhas de rua e de salão; o baião; o batuque e o lundu, intimamente associados ao negro escravo e frequentemente reprimidos pelo poder público; a dança-luta capoeira, praticada principalmente pelos escravos, com seus berimbaus, chocalhos e pandeiros; os ternos, ranchos de reis e bailes pastoris, realizados por grupos de pessoas que se reuniam para louvar o nascimento do Menino Deus, na véspera do Natal até o dia de Reis, faziam parte do cotidiano da Bahia oitocentista.

Salvador contava com um extenso e tradicional ciclo de festas, a maioria de cunho religioso, dentre as quais podemos citar: Santa Bárbara (4 de dezembro); Nossa Senhora da Conceição (8 de dezembro); Natal (25 de dezembro); Ano Novo, acompanhada da procissão do Nosso Senhor dos Navegantes (31 de dezembro e $1^{0}$ de janeiro); São José (19 de março); Nossa Senhora da Boa Morte (15 de agosto) e as juninas de Santo Antônio, São João e São Pedro. Dentre as festas móveis, as mais comemoradas eram a de Nosso Senhor do Bonfim, Sant'Ana, Divino, Corpus Christi e as celebrações da Semana Santa, com suas concorridas procissões.

Quase todas as festividades de caráter religioso tinham o respaldo das Irmandades ${ }^{8}$. Além das cerimônias litúrgicas, havia a parte profana com intensa participação popular. Realizavam-se quermesses, apresentações de grupos musicais, danças, bailes à fantasia, eleições de rainhas e venda de bebidas e comidas típicas. Essas comemorações constituíam a principal maneira de celebrar a vida entre os baianos de todas as camadas sociais.

Embora muitas dessas datas fossem celebradas em outros países, em Salvador, os viajantes puderam vivenciar ou apenas

8 Associações leigas que tinham o objetivo de demonstrar, por meio de festas e procissões, a devoção dos fiéis aos seus santos protetores. 
observar, no papel de espectadores, práticas culturais com traços característicos da cultura popular local. Assim, esses festejos eram alvo da curiosidade e do interesse dos visitantes estrangeiros.

\section{O OLHAR ESTRANGEIRO}

Durante a viagem, o indivíduo encontrava-se longe do seu referencial identitário, tanto cultural quanto geográfico. Deslocado do ambiente no qual normalmente estava inserido, mudava o ritmo de vida e entrava numa nova realidade, no papel de estrangeiro. Nesse sentido, viajar representava, para muitos, liberdade e conquista pessoal fora do domínio familiar.

Para adentrar outro território, realizar as atividades desejadas e até mesmo voltar ao seu país de origem, o viajante dependia da aceitação e da boa vontade dos outros. Independentemente do grau de etnocentrismo, o forasteiro precisava relacionar-se com a comunidade e criar uma rede de contatos que propiciasse sua permanência em cada lugar visitado, a fim de evitar conflitos.

É interessante notar que as cenas e locais que atraíam os visitantes, em geral, não despertavam a atenção dos residentes, havendo divergências de olhares e interesses entre as partes. Agassiz e Agassiz (1975, p. 71) constataram que os brasileiros pareciam "indiferentes aos pormenores da Natureza". Por sua vez, Maria Graham (1956, p. 181) notou que nos eventos festivos dos quais participou no Brasil, os mais velhos habitantes preferiam o que vinha de fora, enquanto os visitantes davam preferência às produções do país.

O estrangeiro enxerga os itens que lhe parecem exóticos, salta-lhe aos olhos o que é diferente, enquanto esses mesmos elementos são minimizados pelos moradores locais, já que foram rotinizados e naturalizados há muito tempo. Desse modo, en- 
quanto os brasileiros, principalmente dos estratos intermediário e superior, tentavam afrancesar seus modos e costumes, os viajantes interessavam-se, sobretudo, pela grandiosidade da fauna a da flora e pelas características do povo. Os aspectos mais relevantes para os visitantes passavam despercebidos ou, ao menos, não eram tão valorizados pela população local, possuindo significados diferentes para esses sujeitos. O forasteiro não compartilha o sentimento de pertença vivido pelo morador e tampouco as particularidades do seu cotidiano. Assim, a representação do lugar é modificada de acordo com as diferentes leituras que dele são feitas.

Os viajantes, que estavam se relacionando com culturas diferentes da sua e conhecendo lugares e povos considerados "na infância" da humanidade, como era o caso dos índios e negros do Brasil, (re)afirmavam-se diante do "outro". Ou seja, eles elaboravam uma imagem da sociedade com a qual entravam em contato ao mesmo tempo em que se conheciam melhor, (re)construindo sua própria identidade. Nesse sentido, ao cruzarem com realidades e paisagens, tanto naturais como humanas, muito diferentes das suas, os visitantes exercitavam o olhar, mesmo que de forma inconsciente.

Para Todorov (1991, p. 99), após o contato com o outro, não é mais possível aderir aos preconceitos da mesma maneira que antes, ainda que o indivíduo não tenha a intenção de desligar-se deles.

A existência dos outros à nossa volta não é um puro acidente. Os outros não são, simplesmente, sujeitos solitários comparáveis ao eu mergulhado em meditação; os outros também fazem parte dela: o eu não existe sem um tu. Não podemos chegar ao fundo de nós mesmos se daí excluirmos os outros. O mesmo acontece com países estrangeiros e as culturas diferentes da nossa: aquele que apenas conhece a sua terra arrisca-se sempre a confundir cultura e natureza, a erigir o hábito em norma, a generalizar a partir de um único exemplo que é ele mesmo. 
Somente o contato com o "outro" permite ao "eu" refletir sobre si mesmo, questionar sua autoimagem e (re)definir-se enquanto sujeito. Portanto, identidade e alteridade são construídas uma em função da outra; afinal, o diferente, ao mesmo tempo que ameaça, é também o que assegura a identidade.

Entretanto, segundo Jovcheloviteh (1998), quando ocorre o encontro de ideias e práticas entre segmentos diversos, o desenvolvimento do vínculo social e afetivo entre os sujeitos só acontece quando se percebe que o "outro" tem uma significação no seu próprio universo. Após o confronto com humanidades distintas, o indivíduo pode até mesmo reiterar, de forma mais elaborada, antigas percepções, negativizando ainda mais a alteridade. Portanto, não basta constatar a existência do "outro"; é preciso reconhecer sua realidade como legítima.

De qualquer modo, as representações também servem para transformar os sentidos e as imagens que nos parecem familiares, pois, confrontados com o novo, precisamos readequar nosso repertório mental. Assim, após a experiência da viagem, o indivíduo pode começar a ver o familiar como incômodo e estreito, fazendo uma nova leitura do seu próprio universo e, de fato, ampliar seus horizontes.

\section{DA BAHIA PARA O MUNDO}

É possível constatar que os visitantes, ao participar temporariamente da dinâmica de Salvador e dialogar com a população local, formularam impressões acerca da cidade e dos seus habitantes, (re)configurando representações do lugar e promovendo diferentes formas de olhar e interagir com o "outro". Ao apresentar um olhar majoritariamente eurocêntrico, esses atores sociais reiteravam imagens de um Brasil exótico, que se encontraria num estágio atrasado de civilização. 
A presença determinante dos homens de cor no cotidiano da cidade, ao mesmo tempo em que foi encarada como um aspecto negativo (já que eram vistos como inferiores), contraditoriamente, configurou-se como um atrativo, conferindo maior visibilidade ao país, juntamente com suas paisagens naturais.

Nessa perspectiva, o Brasil inseriu-se na rota das grandes navegações científicas e também das viagens particulares de aventura e lazer. A cidade da Bahia, contenedora de todos os ingredientes que permeavam o imaginário dos estrangeiros e que tornavam o Brasil um país sui-generis, sobressaiu-se enquanto interessante destino de viagem.

E, assim, os viajantes que aportavam na Baía de Todos os Santos, trazendo novas ideias, concepções de mundo e mercadorias, gestavam imagens e visões deste porto tropical, levando-as para o resto do mundo por meio de suas produções literárias.

\section{REFERÊNCIAS}

AGASSIZ, Jean L .R.; AGASSIZ, Elizabeth C. Viagem ao Brasil: 18651866. Tradução de João Etienne Filho. Belo Horizonte: Itatiaia; São Paulo: Edusp, 1975.

AVÉ-LALLEMANT, Robert. Viagens pelo norte do Brasil no ano de 1859. Tradução de Eduardo de Lima Castro. Rio de Janeiro: INL/ Ministério da Educação e Cultura, 1961.

ARRUDA, Angela. O ambiente natural e seus habitantes no imaginário brasileiro - negociando as diferenças. In: Representando a alteridade. Petrópolis: Vozes, 1998. p. 17-46. (Org.). AUGEL, Moema P. Visitantes estrangeiros na Bahia Oitocentista. São Paulo: Cultrix, 1980.

CHARTIER, Roger. A história da cultura: entre práticas e representações. Rio de Janeiro: Bertrand, 1990.

DARWIN, Charles. Viagem de um naturalista ao redor do mundo. 2. ed. São Paulo: Abril Cultural, [19--]. 
DARWIN, Charles. Voyage of the Beagle. 2009. Disponível em: <http://darwin-online.org.uk>. Acesso em: 02 jan. 2011.

GRAHAM, Maria. Diário de uma viagem ao Brasil e de uma estada nesse país durante parte dos anos de 1821, 1822 e 1823. Tradução de Américo Jacobina Lacombe. São Paulo: Nacional, 1956.

HABSBURGO, Maximiliano de. Bahia 186o: esboços de viagem. Rio de Janeiro: Tempo Brasileiro; Salvador: Fundação Cultural do Estado da Bahia, 1982.

JOFFE, Hélène. Degradação, desejos e o ‘outro'. In: ARRUDA, Ângela (Org.). Representando a alteridade. Petrópolis: Vozes, 1998. p. 109-128.

JOVCHELOVITEH, Sandra. Re(des)cobrindo o outro: para um entendimento da alteridade na teoria das representações sociais. In: ARRUDA, Ângela (Org.). Representando a alteridade. Petrópolis: Vozes, 1998. p. 69-82.

KIDDER, Daniel P. Reminiscências de viagens e permanência no Brasil (Províncias do Norte). Tradução de Moacir N. Vasconcelos. São Paulo: Martins, 1943. v. 2.

MATTOSO, Kátia M. de Queirós. Bahia século XIX - uma Província no Império. Rio de Janeiro: Nova Fronteira, 1992.

REIS, João J. Rebelião escrava no Brasil: a história do levante dos Malês em 1835. São Paulo: Cia das Letras, 2003.

SAMPAIO, Consuelo Novais. 50 anos de urbanização. Salvador da Bahia no século XIX. Rio de Janeiro: Versal, 2005.

SCHWARCZ, Lilia Moritz.O Espetáculo das raças: cientistas, instituições e questão racial no Brasil, 1870-1930. São Paulo: Cia. das Letras, 2002.

SELA, Eneida Maria M. Modos de ser em modos de ver: ciência e estética em registros de africanos por viajantes europeus (Rio de Janeiro, 1808-1850). 2006. Tese (Doutorado em História) - Instituto de Filosofia e Ciências Humanas, Universidade de Campinas, Campinas.

SILVEIRA, Renato da. Os selvagens e a massa: o papel do racismo científico na montagem da hegemonia ocidental. Afro-Ásia, Salvador, n. 23, p. 89-145, 2000. 
SUZANNET, Conde de. O Brasil em 1845. Trad. de Márcia de Moura Castro. Rio de Janeiro: Casa do Estudante do Brasil, 1957.

TODOROV, Tzvetan. As morais da história. Lisboa: Publicações Europa-América, 1991. 


\section{"A Bahia não se desnacionaliza"}

modernidade, civilidade e permanência dos costumes na Salvador republicana

EDILECE SOUZA COUTO

Nas sacadas dos sobrados da velha São Salvador a lembrança de donzelas do tempo do Imperador. Tudo, tudo na Bahia faz a gente querer bem. A Bahia tem um jeito que nenhuma terra tem.

Você já foi à Bahia? Dorival Caymmi 


\section{INTRODUÇÃO}

Salvador foi muitas vezes exaltada por ter sido a primeira capital do Brasil e pela cultura mesclada de elementos europeus, indígenas e africanos. Dessa cidade, os poetas e escritores, nascidos ou aqui radicados, eternizaram as belezas naturais, arquitetônicas e, principalmente, a população mestiça, alegre, festeira e hospitaleira. Ressaltaram que é uma cidade única, com "um jeito que nenhuma terra tem”, como enfatiza Dorival Caymmi. O artista plástico argentino Hector Julio Paride Bernabó, conhecido como Carybé, por meio do desenho, deu formas aos personagens dos romances de Jorge Amado, recusando-se a ver Salvador como uma cidade de contrastes. Segundo ele,

[...] De contrastes seria se fosse uma cidade com coisas que uma nada tem a ver com a outra, mas aqui tudo tem que ver. Tudo está alinhavado, tudo surge do seu bojo mágico com grossas raízes, profundas raízes que se alimentam de rezas, ladainhas, orikis, alujás, farofas de azeite o ano todo, bacalhau na Semana Santa, trêmula luz de velas 
nos altares e água fresca nas quartinhas dos pejis. Tudo misturado (CARYBÉ, 1969, p. 23)

Para Carybé (1969), em Salvador há uma completa fusão de elementos de culturas diferentes. Por sua vez, antropólogos, historiadores, geógrafos e arquitetos sempre procuraram observar, comparar e explicar os aspectos que sobressaem e trazem à tona a diversidade da capital baiana.

Porém, nem tudo é encanto para quem atravessava a larga barra da Bahia. Ao lado das expressões de deslumbramento, também encontramos relatos dos desencantos. No início do período republicano, os registros são repletos de olhares perplexos diante de suas desigualdades. Desigual na geografia, praticamente duas cidades: alta e baixa. Possuía freguesias e arrabaldes quase rurais. A diversidade estava presente no próprio nome da cidade. Foram seis, todos provenientes da combinação da primeira denominação, São Salvador da Bahia de Todos os Santos, dada por Américo Vespúcio à baía encontrada em 1503. A capitania, a província e o estado sempre foram denominados Bahia, mas a capital foi chamada de São Salvador, São Salvador da Bahia de Todos os Santos, Salvador da Bahia, Bahia, Bahia de Todos os Santos e, finalmente, Salvador. Havia desigualdade ainda na distribuição de renda e na vivência religiosa.

Para compor um cenário das mudanças arquitetônicas e culturais que, segundo políticos e intelectuais republicanos, trariam o progresso para a capital, faremos um passeio pelas cidades que serviam de modelo de civilidade - Paris, Rio de Janeiro, São Paulo - e também pelas novas ruas e avenidas de Salvador, seguindo o roteiro e as observações contidas nas crônicas e artigos de jornal escritos por seus habitantes nas primeiras décadas do século XX. Os cronistas e jornalistas deixaram registradas as suas impressões de encantamento e críticas sobre as desigualdades da cidade e o desejo dos seus cidadãos de torná-la moderna e civilizada. 


\section{MODELOS DE MODERNIDADE E CIVILIZAÇÃO}

Os baianos tinham pensamentos contraditórios, confusos entre a permanência da tradição e a adesão à modernidade, na passagem do século XIX para o XX. Mas isso não era algo incomum; pelo contrário, estava de acordo com a mudança de século, momento sempre propício à reflexão, às apreensões e utopias em relação ao futuro. As mesmas ambiguidades da virada do século poderiam ser observadas na Bahia, assim como em outras partes do Brasil e do mundo. No Brasil, havia apego às características e aos costumes dos tempos do Império, valores ligados à monarquia; ao mesmo tempo, um desejo de transformação, o triunfo da modernidade, o progresso e a ciência que representavam o novo século e a República. Falava-se no obscurantismo do período colonial e no dissipar das nuvens, na luz dos novos tempos.

O final do século XIX foi denominado a Belle Époque. Nas sociedades europeias, vivia-se uma época de lealdade à pátria, fausto, luxo e confiança nas verdades, tanto religiosas quanto da Ciência. No Novo Mundo não era diferente, até porque a tendência era a imitação de pessoas, costumes e ideais que atravessavam o Atlântico e aportavam nas cidades, cujos habitantes, pelo menos os representantes das elites, estavam sedentos de novidades.

Durante os oitocentos, a França foi referência de civilidade para o mundo. Paris era a capital do século XIX, segundo Walter Benjamin (1985), e Cidade Luz para os visitantes de suas galerias, salas de exposições e estações de trem - construídas em ferro e vidro para fins de trânsito e iluminadas: primeiramente a gás e, no final do século, a eletricidade. A arquitetura foi substancialmente modificada pelo Barão de Haussmann, que se autodenominava o "artista demolidor". Seu objetivo, ao demolir antigas construções para abrir espaços às largas avenidas, não era propriamente o embelezamento urbano, e sim estratégia para evitar a guerra 
civil, sobretudo a formação de barricadas. Entretanto, seu ideal urbanístico fez com que necessidades técnicas se transformassem em objetos artísticos e as avenidas fossem inauguradas como monumentos.

Paris afirmou-se enquanto capital do luxo e da moda, por isso deveria ser contemplada, admirada e imitada. E continuaria como modelo de vida urbana na virada do século; afinal, os franceses procuravam acompanhar as inovações técnico-científicas e elegeram a luz e a velocidade como símbolos dos novos tempos. A Exposição Universal de 1900, chamada Festa Eletricidade, dá-nos a dimensão da importância das inovações advindas da luz elétrica. Foi preparada para dar ao visitante a ideia de um futuro de abundância, alegria, inovações tecnológicas e ilusão. A eletricidade permitia a esplêndida iluminação de palácios e pavilhões e a projeção dos filmes de Louis Lumière por intermédio do cinematógrafo.

A velocidade deveria estar em toda a parte: nas ruas (por meio de automóveis e bondes elétricos), no mar (em navios a vapor), no céu (com máquinas voadoras, como os dirigíveis de Ferdinand von Zeppelin e Alberto Santos Dumont) e até mesmo embaixo da terra (o metrô de Paris foi inaugurado em 1900). O objetivo era transportar passageiros com o máximo de velocidade possível. Era preciso aperfeiçoar o avanço simbolizado pela ferrovia. A velha utopia de controlar o tempo e o espaço parecia se tornar realidade.

Todas essas inovações, surgidas a partir de 1870, fazem parte da Segunda Revolução Industrial, conhecida como CientíficoTecnológica. É claro que uma parcela muito pequena das elites urbanas tinha acesso a esses avanços e, mesmo assim, com grande desconfiança e incredulidade, mas não resta dúvida de que aquela era a época de consolidação do capitalismo e seus representantes almejavam vencer barreiras e fronteiras. Por vezes, as novas invenções eram consideradas "curiosidades mecânicas" ou "brinquedos 
de ricos", sem grandes consequências para a humanidade. Porém, se poucos indivíduos ricos podiam cruzar os oceanos e chegar aos grandes centros europeus para conhecer os inventos e com eles ter contato, nem que fosse num ilusório pavilhão de exposição, e passear pelos canteiros de obras, houve avanço significativo também nas comunicações. O rádio, o telégrafo e o telefone levavam as notícias com mais rapidez às diversas partes do mundo.

Os novos inventos encantavam, mas também geravam sustos e reprovações, sobretudo porque dependiam de mudanças estruturais na arquitetura das cidades. Era preciso abrir novas vias para automóveis e bondes elétricos, instalar fios e cabos de eletricidade e escavar o solo para construir as linhas subterrâneas do metrô. Tudo isso trazia incômodos aos transeuntes, causava a demolição de prédios e igrejas de grande valor arquitetônico e sentimental, sem falar dos acidentes provocados pelos choques de automóveis mais velozes com carruagens e bondes ainda de tração animal. Contradições de um progresso desejado.

Apesar das ambiguidades, havia a crença de que era impossível retardar o progresso e a corte brasileira queria estar inserida nos avanços: saraus dançantes, apresentações de companhias europeias de dança e teatro, linhas telefônicas que atendiam ao Rio de Janeiro e se estenderam até Petrópolis, etc. As transformações que incluiriam a capital do Brasil entre as cidades modernas e civilizadas começaram no Império, mas ganharam destaque com a chegada da República. O novo regime passou a representar a modernidade. Os entraves não eram poucos, mas havia empenho para se tirar o país do "atraso monárquico" e da "barbárie da escravidão". Consideravase necessário modificar os símbolos nacionais, como o hino e a bandeira, e também os aspetos físicos das cidades.

Para fazer do Rio de Janeiro um cartão-postal, o Presidente Rodrigues Alves, na gestão entre os anos de 1902 e 1906, não mediu esforços. Compôs uma equipe com plenos poderes para realizar 
a modernização. Engenheiros, médicos e higienistas se tornaram ícones e suas obras imitadas por políticos de outras regiões do país. O plano tinha três eixos: o porto, sob a responsabilidade do engenheiro Mauro Müller; o saneamento, que deveria livrar a cidade das epidemias infecciosas, foi entregue ao médico sanitarista Oswaldo Cruz; e a reforma arquitetônica que seria realizada pelo engenheiro Pereira Passos. Este último tinha como credencial o fato de ter conhecido as obras urbanas de Paris, empreendidas pelo Barão de Haussmann.

Para os cariocas, o principal símbolo de modernidade e civilidade foi a nova Avenida Central, atual Avenida Rio Branco. Os prédios, construídos com mármore e cristal, possuíam fachadas art nouveau e abrigavam lojas de produtos importados. A iluminação elétrica era feita com modernos lampiões. Nesse novo espaço, não cabiam moradores e frequentadores pobres e negros, com seus bailados, cerimônias, festas religiosas e procissões que lembrassem a África e a escravidão. O Entrudo, brincadeira de raiz lusa, passou a ser encarado como um atraso do período colonial, inconveniente e sujo, portanto, inapropriado aos novos padrões de comportamento e moralidade. Foi substituído pelo Carnaval, de preferência, aquele dos desfiles de fantasias e máscaras à maneira de Veneza.

A capital do Brasil não foi a única a se transformar em cartãopostal e modelo de civilidade. Ainda por volta de 1870, São Paulo começou a dar os primeiros passos em direção à modernidade. Os habitantes da cidade, diante da sua próspera lavoura cafeeira e de seu status de entreposto comercial e financeiro, propiciador da entrada no país do capital internacional, sentiam urgência de modernização. Havia a intenção de transformá-la na "Metrópole do Café".

Coube ao governador da Província, João Theodoro Xavier de Mattos, dar início às reformas: na zona urbana, era preciso abrir 
novas ruas e avenidas, criar jardins públicos, etc. A exemplo da Avenida Central no Rio de Janeiro, São Paulo teria o seu ícone de modernidade: a Avenida Paulista, inaugurada em 1881, além de bairros chiques, como Campos Elísios e Higienópolis. (COSTA; SCHWARCZ 200o, p. 32-33) Há a informação de que alguns edifícios arrojados também trouxeram inovações na arquitetura: as Secretarias de Estado, no largo do Palácio, e a Escola Normal, na praça da República. Vale destacar também o viaduto do Chá, que se tornaria um cartão-postal paulistano. Numa demonstração de que os grandes produtores de café, patrocinadores das reformas, também se interessavam pelos avanços científicos, na década de 1890 foram construídos prédios para abrigar o Instituto Histórico e Geográfico, a Escola Politécnica, a Sociedade de Medicina e Cirurgia, o Instituto Butantã, a Escola Livre de Farmácia e o Museu Paulista. Enquanto isso, fora do perímetro urbano, tornava-se urgente expandir as estradas e ferrovias para a escoação do café das fazendas ao porto de Santos.

Assim como os habitantes de Paris, os paulistanos se despediram do século XIX com o brilho da luz elétrica, que fazia, inclusive, movimentar os bondes em direção ao novo milênio. Em 1901, a promissora cidade de São Paulo ganhou a Estação da Luz, nome apropriado à construção em material importado da Inglaterra. A referência arquitetônica vinha de longe, uma cópia da estação de Sidney - Austrália. A estação paulistana era um entroncamento ferroviário, ponto de chegada e partida dos produtos produzidos na Província, parte deles destinados à exportação (o café, por exemplo) e os importados de luxo para o consumo das famílias abastadas. Porém, nem tudo era luxo naquele espaço. Ali também desembarcavam os imigrantes, principalmente italianos, que substituiriam o trabalho escravo nos cafezais e fariam funcionar a nascente indústria brasileira. 
A modernização nas três cidades comentadas gerou ânimo, satisfação, encantamento, mas também incredulidade, sustos e reprovações. Porém, parecia mesmo ser impossível reter os avanços, as mudanças pensadas não para um futuro distante, e sim para a aurora do século XX.

\section{TENTATIVAS DE MODERNIZAÇÃO NA SALVADOR OITOCENTISTA}

Antes de tratar especificamente da modernização baiana no século XX, é preciso recuar no tempo e fazer uma breve explanação sobre as tentativas de reforma urbana empreendidas durante o século XIX. Vale lembrar que, nos oitocentos, os políticos baianos também estavam atentos às transformações na Europa, na corte imperial brasileira e em São Paulo. Podia-se observar um esforço para que a província da Bahia, especialmente Salvador, acompanhasse o desenvolvimento de outras capitais.

Aparentemente, Salvador era uma cidade dinâmica e rica, mas escondia uma grande fraqueza: continuava sendo uma metrópole colonial, depósito de produtos manufaturados vindos do exterior ou do sudeste do país, pois, no final do século XIX, Rio de Janeiro e São Paulo passavam pelo processo de desenvolvimento industrial. A economia baiana alternava períodos de repressão e recuperação, sendo que as fases de desenvolvimento foram acompanhadas de tentativas de modernização urbana.

Ana Fernandes e Marco Aurélio Gomes (1992, p. 53-68) analisaram dois momentos na História de Salvador nos quais houve a junção entre crescimento econômico e reformas urbanas. O período de 1810 a 1818 , durante o governo do $8^{\circ}$ Conde dos Arcos, foi de desenvolvimento, com rentáveis contatos e alianças internacionais, sobretudo com a Inglaterra, nação industrializada 
e beneficiada com os acordos de comércio e navegação estabelecidos durante a instalação da corte portuguesa no Brasil. Foram realizados melhoramentos no porto e em toda a área comercial da Cidade Baixa.

O porto era tão vital para a Bahia oitocentista que a Cidade do Salvador também era chamada Cidade Armazém, Cidade Formigueiro e Cidade Porto, como destaca a estudiosa das atividades portuárias na capital Rita Rosado (2004, p. 8). Ao atravessar a barra e atracar no porto, os navios, vindos dos Estados Unidos, da Europa (especialmente da Alemanha, França, Holanda e Bélgica, além de Portugal), África e Ásia, ou das demais províncias (Sergipe, Alagoas, Pernambuco e Rio Grande do Sul) faziam o desembarque e novamente o embarque de mercadorias, homens, ideias, hábitos e costumes. Segundo Rosado (2004, p.10-11), a intensa movimentação comercial pode ser percebida pelas construções e melhorias nos estaleiros (responsáveis pela assistência técnica e diversas formas de ajuda às embarcações e tripulações), trapiches e armazéns (que armazenavam os produtos - os trapiches alfandegados também serviram de alfândega) e ainda a construção da nova sede da Alfândega Provincial, casarão imponente, em estilo neoclássico, inaugurado em 1861, onde atualmente funciona o Mercado Modelo.

De acordo com Ana Fernandes e Marco Aurélio Gomes (1992, p. 53-68), entre os anos de 1850 e 1890, aconteceu o segundo momento de transformações urbanas, apesar dos ciclos de depressão. Os anos 50 foram marcados pelas epidemias de febre amarela e cólera, causadas, segundo os médicos e sanitaristas, pela insalubridade. Porém, a dramática situação forçou o poder público a investir na construção de hospitais e cemitérios, melhorar os serviços públicos de limpeza, iluminação a gás, distribuição de água, esgotamento sanitário, assim como ampliar o sistema viário da cidade. 
Kátia Mattoso (1978, p. 350-351) identificou três momentos na economia baiana da Primeira República. O período de 1889 a 1897 foi de recuperação econômica em decorrência da alta nos preços dos produtos agrícolas e a consolidação do cacau, da borracha e dos carbonados como produtos de exportação. Os anos entre 1897 e 1905 foram de depressão, causada pela crise da economia europeia, dificuldades para a produção e comercialização do açúcar, flutuação do preço do cacau e secas que atingiram até mesmo o litoral. Entre 1906 e 1928, veio novamente a recuperação, motivada pelo restabelecimento dos preços dos produtos agrícolas e novas transações comerciais. A recuperação econômica nas duas primeiras décadas do século XX, identificada por Fernandes, Gomes e Mattoso, abrange o último surto de modernização.

Entretanto, a cidade e seus habitantes viviam das glórias passadas, do prestígio de antiga metrópole colonial e primeira capital do Brasil, de sua importância como centro administrativo e religioso. Havia um desejo de modernização, mas

A passagem da velha Salvador escravista à cidade 'enfim civilizada' se dá em um tempo bem mais longo, se constrói através de interesses e ações múltiplas, combina várias esferas de intervenção e traduz, na cidade, uma nova heterogenia: a que coloca, lado a lado, novo e velho interagindo e sustentando a montagem de diversas idealizações urbanas sobre Salvador. (FERNANDES; GOMES, 1992, p. 55)

Segundo Mário Augusto Santos (1992), dois fatores interligados - as estagnações demográfica e industrial - contribuíram para o lento processo de mudanças. O pequeno crescimento demográfico não favorecia a formação da mão-de-obra necessária ao mercado interno e ao desenvolvimento industrial. O ramo de atividades que mais se desenvolvia era o setor primário. A cidade permanecia repleta de áreas verdes, vales desabitados e distritos 
urbanos e arrabaldes ocupados por estábulos, hortas, chácaras, roças e fazendas ou separados por imensos espaços vazios.

O setor produtivo era caracterizado pelas atividades do artesanato doméstico, que abastecia as lojas com acessórios do vestuário, das pequenas oficinas e fábricas, empresas domésticas, de apenas um ou dois empregados e sem trabalho assalariado, e da construção civil, tradicional forma de emprego da mão-de-obra masculina. Em 1893, existiam seis fábricas têxteis que reuniam de 700 a 800 operários. Em 1925, esses estabelecimentos industriais eram sete e tinham ao todo 4.870 empregados.

A primeira capital do Brasil não conseguia nem mesmo manter a influência regional, passando por um refluxo econômico em função do declínio da indústria açucareira. Nas três primeiras décadas do século XX, a região sul do estado, principalmente o eixo IlhéusItabuna, mostrou um certo dinamismo com a cultura do cacau. Salvador tornou-se o centro comercial e exportador do produto. Entretanto, a nova atividade econômica não significou investimento de capitais na Região Cacaueira e nem mesmo na Bahia. Os coronéis do cacau preferiam investir os seus lucros na capital federal.

Apesar das crises econômicas, não podemos negar que alguns setores evoluíram. É o caso, por exemplo, dos transportes. As inovações parecem simples, mas começaram a mudar o cotidiano a partir da década de 1870. São dessa época os primeiros bondes puxados por cavalos. No mesmo ano, a Cidade Baixa teve a primeira linha de bonde, fazendo a ligação entre as freguesias da Penha, Conceição da Praia e Pilar. Apesar do preço alto para a maioria da população, os bondes foram responsáveis por diminuir o tráfico a pé ou em cadeirinhas de arruar. Por outro lado, verificaram-se também significativos avanços técnicos. O famoso elevador, construído pelo comerciante e comendador Antonio de Lacerda, começou a transportar os trabalhadores da Cidade Baixa até a paróquia da Sé e vice-versa em 1873. 
Como vimos, as tentativas de modernização empreendidas durante o Império buscavam realizar reformas na infraestrutura de Salvador, especialmente nos locais de maior atividade econômica, como a Cidade Baixa, de intensa movimentação em torno do comércio, entrada e saída de produtos por intermédio do porto. A República trouxe um novo viés à modernidade e civilização: mudanças de costumes.

\section{A MODERNIZAÇÃO DA CIDADE REPUBLICANA}

A frase que dá título a este texto, A Bahia não se desnacionaliza, foi retirada de uma matéria do jornal Diário de Notícias, de 1912, e representa bem as contradições no pensamento da elite letrada baiana nas primeiras décadas do século XX. Os profissionais de imprensa afirmavam que falavam em nome dos seus leitores desejosos de transformações, mas ao mesmo tempo criticavam as intervenções e obras em curso e defendiam a permanência de determinados edifícios e tradições populares que representavam a Bahia e o Brasil; portanto, era preciso manter as características e símbolos da nacionalidade.

No início da República, os políticos, médicos sanitaristas, higienistas, educadores e jornalistas baianos estavam atentos à divulgação, pela elite nacional, dos ideais de progresso e civilidade e desejavam modernizar e civilizar Salvador. Acreditava-se que a capital da Bahia precisava urgentemente se livrar de suas características coloniais. Para isso, pensavam na reordenação do espaço urbano e na resolução dos problemas causadores do atraso. Eram deficientes o saneamento básico, o abastecimento de água, os serviços de esgoto e a coleta de lixo, e precárias as condições de higiene e saúde da população.

Nos editoriais e matérias - nem sempre assinados - dos jornais de Salvador, parte dos jornalistas escrevia sobre a insatisfação 
dos moradores da capital com as precárias condições de moradia, os frequentes surtos de epidemias, a ausência dos serviços básicos de saúde. A matéria Em torno dos melhoramentos, publicada no jornal Diário de Notícias, em 25 de junho de 1912, ilustra bem a identificação dos problemas:

Somos os tristes moradores de uma capital onde existem todos os inconvenientes da vida em sociedade, sem nenhuma das suas vantagens; vida cara, desde os aluguéis das habitações, até as exigências do vestuário; população densa; casas aglomeradas, mal arejadas e [...] pelo outro lado, quanto a vantagens, nada, desoladoramente, nada. Cerca de 300.00o pessoas quase morrendo de tédio, sem diversões nem logradouros públicos e, ainda a sombrearlhes o espírito atribulado, a preocupação dos males epidêmicos que vão ceifando, assustadoramente, a vida, tal como a febre amarela, o mal levantivo, a varíola, a disenteria e, com uma fúria inominável, a tuberculosa que leva para o seu ativo parte dos serviços do nosso obituário.

Os jornalistas identificavam também os problemas de infraestrutura da cidade e defendiam as intervenções na arquitetura, como demonstra a matéria Os desmoronamentos: avisos do destino, do mesmo jornal Diário de Notícias, em 12 de outubro de 1912:

A velha capital da antiga metrópole, quando dizemos velha, não é em relação aos seus trezentos e oitenta e três anos de idade, mas sim, a seu aspecto colonial - está cheia de edificações seculares, de altas casas roídas, de paredes esboroadas, com grossos toros de pau servindo-lhes de amparo, de número considerável de muros fendidos, tudo ameaçador, tudo em iminência de desastres lamentáveis.

Todas essas intervenções estavam presentes no projeto de reformas urbanas de José Joaquim Seabra, que governou a Bahia em dois mandatos: 1912-1916 e 1920-1924. Era jurista e tinha uma longa experiência na administração pública. Foi deputado, exer- 
ceu a função de ministro da Justiça na gestão de Rodrigues Alves (1902-1906), ministro da Aviação e Obras Públicas no governo de Hermes da Fonseca (1910-1914), e acompanhou as reformas do Rio de Janeiro no governo de Pereira Passos. J. J. Seabra pretendia fazer uma grande intervenção urbana: ampliação de ruas, construção de novas vias, abertura de avenidas, construção e reforma dos edifícios públicos.

Esperavam-se, com entusiasmo e às vezes também ceticismo, as reformas na Cidade Baixa, especialmente na zona portuária. A matéria $A$ remodelação e os negocistas, publicada pelo Jornal $A$ Tarde em 19 de outubro de 1912, afirmava que mesmo os "espíritos tradicionalistas", inacessíveis aos "reclamos do progresso" e, portanto, defensores dos velhos casarões, "cenário de grandes feitos históricos”, não raro também aplaudiam a remodelação da cidade. Se havia controvérsia, era sinal do interesse dos baianos no acompanhamento das obras:

Muitos anos - alguns séculos - de anquilose (sic) e abandono haviam habituado o nosso povo a ser cético quanto às promessas da melhor sorte da cidade, de modo que não é sem o espanto da surpresa que todos verificamos agora a injustiça da nossa descrença, assistindo, satisfeitos, a transformação completa da cidade baixa, muito próxima de poder ser vista por gente que tenha andado ao contacto das metrópoles civilizadas. Mais alguns meses, e das vielas escusas e os casarões contemporâneos de dom João VI não restarão senão a lembrança, sem saudades. (A REMODELAÇÃO..., 1912)

Entretanto, o ceticismo não era infundado. Muitas vezes os baianos eram obrigados a conviver com a poeira e o entulho da demolição de antigas casas, a insatisfação e a descrença diante da promessa de obras não iniciadas ou inacabadas. Essa era a realidade da Cidade Baixa, como reclama o jornalista de A Tarde em 22 de outubro de 1912, no sugestivo título Avenida para inglês ver: 
Há contratantes e senhores afortunados dos negócios obtidos facilmente que são de uma má fé inesgotável.

E para satisfazerem a sua ganância, não encontram empecilhos aos processos da ardileza e da humildade.

Então, curvam-se, suplicam e prometem as casas da Índia em troca do que adquirirem.

Foi o que aconteceu com a Companhia Cessionária do nosso porto [que] tem vivido das reformas de uma concessão que há cerca de vinte anos desfruta, promoveu nova revisão de seu contrato.

[...] Solicitaram então a prorrogação do prazo da concessão e outras modificações, dando em troca a abertura de uma grande avenida, ao longo do cais, do Pilar a Jequitaia.

De fato, a liberação para as obras de remodelação do porto aconteceu quando J. J. Seabra ainda era ministro. A renovação do contrato, com a promessa de construção da avenida citada pelo jornal, deu-se no ano de sua posse no cargo de governador da Bahia em 1912. A mesma matéria de $A$ Tarde nos informa sobre a festa oferecida pela cessionária após firmar o novo acordo:

[...] Afinal, tomando posse o atual governador, a Cessionária, talvez para desfalcar o descaso com que trata os seus compromissos, resolveu fazer uma festa inaugural com bandeiras e champagne, a cujo espocar, se expressaram promessas formosas que enquanto 'o diabo esfregasse um olho’ a avenida estaria aberta. (AVENIDA..., 1912)

Após a festa, começaram as desapropriações, como a do trapiche Querino, e de algumas casas. O jornalista afirma que, no máximo, foi desapropriada uma dúzia de imóveis. Porém, os meses se passavam e nada de avenida. Crescia a descrença em relação às promessas da cessionária e a certeza de que se as autoridades não tomassem uma "determinação enérgica”, os baianos teriam apenas "uma avenida em decreto". 
A modernização tinha os seus limites. O culto a Nossa Senhora da Conceição da Praia foi um dos primeiros a serem difundidos no Brasil. Tomé de Souza trouxe a imagem, mandou erguer uma capela à beira da praia e a Virgem, que era padroeira do Império Português, seria também padroeira do Brasil até 1930. Certamente a igreja do Bonfim era o principal local de peregrinação dos baianos, atraindo gente de todas as classes sociais. Porém, a igreja da Conceição, situada na Cidade Baixa, tinha um culto mais aristocrático; afinal, foi organizado por uma irmandade de portugueses e só começou a admitir irmãos nascidos em território nacional a partir da República, mas continuava sendo exclusiva de homens brancos.

Assim, os baianos acreditavam que o largo da Conceição deveria estar no eixo das reformas. Entretanto, uma matéria do jornal Diário de Notícias, de 3 de dezembro de 1915, revela que a área continuava sem calçamento e higiene, com lixo e entulho acumulados, que em dias de chuva formava lama a ponto de impedir a realização da procissão no dia 8. O jornalista comentou com indignação que o terreno "onde se ergue a mais bela e mais artística matriz de todas as dessa capital” havia sido esquecido pelo poder público. Dizia que o local era ocupado por "Materiais imprestáveis, pedras atiradas pelos cantos, vegetação daninha em desvãos onde a imundície culmina, nauseante mictório público, valhacouto de vagabundos e mendicantes". E concluía que o "asfalto da remodelação" ali não havia chegado.

Dentre as principais metas de J. J. Seabra, destaca-se a construção de uma avenida que percorresse toda a cidade, estendendo-se da Sé ao Rio Vermelho, e que viesse a se constituir em cartão-postal. Essa grande via seria composta de canalizações para esgoto de águas pluviais, instalação de luz elétrica e arborização. Para a viabilização do projeto, antigos edifícios deveriam ser demolidos: Instituto de Higiene, Imprensa Oficial, o primeiro 
quartel da Vila Policial do Estado, a garagem do antigo Passeio Público, a entrada do departamento do Quartel da Cavalaria, o Museu-Escola, o Pavilhão de Ondina, o Pavilhão Kroepelin, o Pavilhão dos Tuberculosos, a residência do diretor, o Hospício S. João de Deus, as fachadas do Rosário, da Capela e do Convento das Mercês, o Palácio do Progresso.

A abertura dessa via, inaugurada no dia comemorativo da Independência do Brasil - por isso chamada Avenida Sete de Setembro - foi a mais controvertida das intervenções realizadas por Seabra. Ocorreram diversas manifestações contrárias às demolições e desapropriações dos edifícios que faziam parte do patrimônio histórico e religioso da cidade. Talvez a mais intensa reação popular tenha sido aquela contrária à demolição do Mosteiro de São Bento. O seu abade reagiu e saiu vitorioso da luta pela preservação do edifício. A igreja da Sé não teve a mesma sorte. Apesar dos protestos da população e do clero, o templo foi demolido para que em seu terreno passasse a linha de bonde elétrico.

Desde o final do século XIX, os incêndios eram comuns, principalmente na Cidade Baixa. E o poder público aproveitava esses "acidentes" para justificar o aproveitamento do terreno de uma igreja em parte demolida. Em 7 de janeiro de 1902, o relatório do Intendente José Eduardo Freire de Carvalho Filho afirmava a necessidade de "abertura de uma artéria ligando o Largo das Princesas à rua de Santa Bárbara”. Segundo Carvalho Filho citado por Barbosa (1970, p. 147),

Causas diversas retardaram esse consentimento, não sendo de menos alcance a necessidade de um grande corte em parte da Igreja do Corpo Santo, ponto inicial de uma das ruas [...]. O pavoroso incêndio de $1^{\circ}$ de dezembro de 1899 simplificou em parte o projeto que me animou [...]. Para removê-la, porém, confiava nos intuitos progressistas e patrióticos do eminente pastor da Igreja Bahiana, o Exmo. Revmo. Sr. D. Jerônimo Tomé da Silva, em que 
encontrou esta administração precioso auxílio, pois, graças ao prestígio de sua Excia. Revma., concedeu a Cúria Romana a indispensável permissão.

Entretanto, os projetos de reformas não estavam restritos à infraestrutura urbana. O fenômeno assumiu dimensões sociais e culturais. Civilizar significava regulamentar o uso do espaço, mas implicava a mudança de hábitos da população e na "moralização dos costumes". Tentava-se impedir a mendicância, os cultos africanos e aqueles que ainda tinham referências das religiões indígenas e as diversas formas de manifestações lúdicas populares.

Os cultos de origem africana e indígena sofriam constantes críticas. Acreditava-se que era preciso retomar os valores e dogmas do Catolicismo, pois, apesar dos esforços dos primeiros religiosos, "a religião no Brasil não se definiu, não se integralizou", como afirmava o editorial do jornal Diário de Notícias em 9 de dezembro de 1912, ao tratar do tema A nossa educação religiosa. Para tal empreitada, seria necessário a imprensa fazer uma tenaz campanha contra a "má orientação cívica e religiosa" do povo baiano. Identificava a origem do problema na colonização, quando os portugueses, de "sangue impuro com mescla de sangue mouro", juntaram-se com "os caboclos de vida errante, dados à prática de fetichismo, indolentes, inadaptáveis à civilização”. Outras religiões, como protestantismo, espiritismo e islamismo, também eram consideradas prejudiciais à sociedade baiana. Porém, a recorrência à escravidão africana lhe havia causado um mal ainda maior.

Ainda segundo o redator do mesmo editorial, mais grave era o fato de o culto africano ser frequentado por senhoras educadas da alta sociedade, que sabiam falar francês, estudavam Geografia e História, tocavam piano, discutiam transcendentes questões filosóficas, além de política nacional e estrangeira, iam à missa, ouviam os sermões do padre, contra as superstições e feitiçarias, e na volta, "com a mesma contrição, com a mesma fé”, procuravam 
"a casa da mulher das cartas, do africano que bota a mesa, do explorador que cura por meio do espiritismo" e ainda realizavam oferendas.

\begin{abstract}
Nas madrugadas das segundas-feiras, ou das sextas-feiras de cada semana, porque a polícia aqui acorda muito tarde, aparecem nas encruzilhadas da cidade, na baixa da ladeira do cemitério da Quinta, na baixa da ladeira de Nazaré, cestos, panos vermelhos, milho torrado, algumas moedas de cobre, penas de galinha, às vezes galinhas vivas, de laços de fitas nas asas, toda uma infinidade de porcarias, tingidas de azeite de dendê e a que o vulgo dá o nome pitoresco e inexpressivo de bozó. (EDITORIAL, 1912)
\end{abstract}

Os jornais Diário de Notícias e A Tarde fizeram acirradas campanhas contra o Candomblé e os costumes afro-baianos, que os civilizadores identificavam como "feitiçaria" e "medicina oculta”. Criticavam a polícia por considerar que, dos soldados ao alto escalão, encontravam-se pessoas vinculadas às casas de culto e por isso, apesar das "batidas" policiais, não tomavam atitudes mais enérgicas para reprimir os "centros fetichistas". Os próprios jornalistas percorriam os terreiros para se inteirarem das práticas, como revela a matéria No reino do fetichismo: abusões e contágios, do Diário de Notícias de 30 de novembro de 1920. Afirmavam ter visto os crentes fazendo "preces supersticiosas", imposição de mãos e uso de ervas santas em infusão. Mas o que os escandalizava era encontrar sujeitos, chamados "tipos pernósticos", que diziam curar enfermos por meio de "processos ocultistas".

Havia uma espécie de união entre as autoridades religiosas e civis para o controle e até mesmo a desarticulação das manifestações populares, especialmente aquelas nas quais tomassem parte os africanos e seus descendentes. O arcebispado, por meio de portarias e textos divulgados nos jornais religiosos, ditava regras de comportamento e vida religiosa. O poder público editava as Posturas Municipais, proibindo o Entrudo, fogos, jogos, máscaras 
e brincadeiras nos largos, praças e avenidas remodeladas, e era responsável por fazer com que elas fossem executadas. E cabia à polícia vigiar e punir os infratores.

As críticas e as sanções aos festejos e costumes tradicionais sempre fizeram parte da Igreja e do poder público. O clero tentava tornar o Catolicismo dos seus fiéis o mais ortodoxo possível, sem interferências das religiões africanas. A preocupação dos políticos e da polícia era, porém, de outra ordem. Na primeira metade do século XIX, o temor era de que os escravos utilizassem o espaço das festas para promover insurreições, o que não era incomum, uma vez que o Levante dos Malês aconteceria no final de semana dos festejos do Senhor do Bonfim e a Romaria dos Jangadeiros (homenagem dos pescadores do Rio Vermelho a Sant'Ana, que atraía desde os veranistas da capital aos escravos e libertos para o arrabalde) foi, diversas vezes, proibida para se evitarem situações de rebeldia. (REIS, 2001)

Entretanto, passado o temor da rebeldia escrava, não diminuíram as críticas e tentativas de controle das manifestações populares. No período republicano, a elite intelectual e defensora da modernização também tinha suas estratégias para eliminar os indesejáveis festejos. Para os civilizadores, finalmente era chegado o momento de promover um branqueamento da sociedade baiana, acabar com os batuques, extinguir ritos religiosos e festejos públicos dos negros ou qualquer outro referencial da cultura africana. Em Salvador, o processo de desafricanização das ruas começou a ficar nítido a partir das tentativas de expulsar os vendedores dos largos, praças e avenidas modernizadas e das interdições nas festas religiosas populares.

Vimos anteriormente que no Rio de Janeiro e em São Paulo, a população pobre e negra foi retirada nos espaços remodelados. Na Bahia aconteceu o mesmo. Uma das primeiras providências do poder público baiano foi modificar o pequeno comércio desen- 
volvido pelos negros, sobretudo pelas mulheres negras. As iguarias vendidas na rua e a indumentária das baianas, de influência africana, foram condenadas. Ainda havia um problema religioso, uma vez que a venda de comida afro-baiana era encorajada pelo Candomblé, um meio das filhas-de-santo obterem dinheiro para a realização das suas obrigações rituais.

Os jornalistas baianos se referiam à vendedora de rua como a “mulher de saião". (PEIXOTO, 1980) A expressão pejorativa servia para desqualificar a mulher negra e pobre, cujas roupas lembravam a África, a escravidão, e em consequência, a barbárie e o atraso da época colonial, da qual a elite queria a qualquer custo se livrar. Os médicos, sanitaristas e higienistas tiveram uma preocupação obsessiva com a qualidade dos alimentos vendidos nas ruas de Salvador. Consideravam os pratos da cozinha afro-baiana - preparados, muitas vezes, nas vias públicas e expostos em tabuleiros, bandejas e gamelas - alimentos gordurosos, condimentados, impregnados de suor, enfim, de fabricação duvidosa. Representavam, portanto, uma porta de entrada para os micróbios e vírus que prejudicavam a já combalida saúde dos baianos.

Em 1889, ano da Proclamação da República, a festa do Senhor do Bonfim sofreu uma de suas principais interdições. Por determinação do Arcebispado, a lavagem da igreja foi proibida. No entanto, no dia 17 de janeiro de 1890, as baianas resolveram desacatar a ordem e dirigiram-se à colina, vestidas à maneira africana (blusas e saias brancas e rendadas, pescoços ornados com colares e guias dos Orixás), munidas de vassouras e potes de barro com água de cheiro (água preparada com infusão de ervas aromáticas que, segundo o Candomblé, quando derramada na cabeça do fiel, livra-o de males como mal olhado e feitiço). A polícia apreendeu esses objetos, mas não foi capaz de coibir totalmente o ritual. Proibidas de lavar o interior do templo, as baianas passaram a 
lavar apenas a escadaria, suficiente para garantir as bênçãos do Senhor do Bonfim e Oxalá.

Foi realizada também, por meio dos jornais, uma verdadeira campanha contra o hábito de acender fogueiras e soltar fogos (buscapés, bombas e roqueiras). Os chamados fogos de planta eram rasteiros, soltavam muita fumaça e suas faíscas poderiam atingir os festeiros. Por isso foram considerados perigosos e proibidos. Em 22 de junho de 1912, quando as brincadeiras das noites de São João alegravam os baianos, o jornal Diário de Notícias as considerou "[...] um vestígio da barbaria, da selvageria, da brutalidade, das eras coloniais, quando aqui ainda era, quase, tudo mata brava, quando aqui ainda era povoado de indígenas ferozes e de colonos também ferozes". (FOGOS..., 1912)

A mesma matéria, intitulada Fogos soltos, dizia que, com o incentivo das reformas urbanas, o costume seria extinto. Afinal, no Rio de Janeiro, ninguém tinha mais a audácia "de acender uma fogueira, de atirar um buscapé na avenida Rio Branco”, símbolo da modernização daquela cidade. Mas em Salvador, segundo o Diário de Notícias, as posturas não tinham execução. E não era mentira. Mesmo quando as Posturas Municipais proibiam soltar fogos, não eram suficientes para acabar com o brilho e a animação das noites juninas. E os soteropolitanos, inclusive as autoridades, não levavam a sério as interdições e participavam das brincadeiras:

[...] homens do povo, muita gente chamada boa, muitos indivíduos que se diziam educados, muitos moços que se tinham como civilizados e instruídos, muitos parentes de autoridades policiais, de chefes políticos, mesmo da polícia e do exército. (FOGOS..., 1912)

A campanha contra os fogos, empreendida pelos jornalistas, estava baseada nos Códigos de Posturas Municipais. O Código de 1901 proibia os fogos de planta e regulamentava os fogos de artifício, mais sofisticados, fabricados e queimados por especialistas 
em pirotecnia. Porém, até mesmo essa nova forma de iluminar o céu nas noites de festas religiosas não deixou se sofrer as intervenções e penas da municipalidade. A prevenção de acidentes e a manutenção da civilidade ultrapassam a fase áurea das reformas urbanas de Salvador (1912-1916). O Código de 1920 tem um capítulo dedicado à regulamentação das manifestações populares, intitulado Do entrudo, Máscaras e confetti, Espetáculos e fogos de artifícios. A Postura 148 determina: "Ninguém poderá dar espetáculos públicos, armar ou queimar fogos de artifícios nas ruas, praças e avenidas desta cidade e subúrbios, sem a competente licença da Municipalidade”. (SALVADOR. Prefeitura Municipal. Conselho, 1920) Previa o pagamento em forma de caução, averiguação pela Diretoria de Obras Públicas e multa pelos possíveis danos causados. Os fogos de artifícios eram permitidos. Porém, outros tipos, considerados perigosos, estavam proibidos pela Postura 149: "Fica terminantemente proibido o uso de fogos soltos, busca-pés, bombas de clorato e espadas no perímetro urbano”. (SALVADOR. Prefeitura Municipal. Conselho, 1920)

Apesar das multas cobradas àqueles que desrespeitassem as normas, elas foram muitas vezes desobedecidas. As oficinas para o fabrico dos fogos proibidos continuaram funcionando. Em 7 de agosto de 1929, o Conselho Municipal mais uma vez tentou resolver o problema com uma nova Postura. Assim determina o Artigo $1^{0}$ : "Fica expressamente proibido o fabrico e vendagem de busca-pés, bombas de pavio de clorato ou de choque (vulgarmente conhecidas pelo nome de bombas de parede)". O Artigo $2^{\circ}$ estabelece que as fábricas ou oficinas de fogos só poderiam fabricar as bombas de pavio quando seu uso fosse aplicado aos foguetes de ar.

Vimos várias formas de interdições e tentativas de mudanças nos costumes baianos. No entanto, não havia unanimidade quanto à forma de civilização que deveria ser implantada na Bahia. De vez em quando aparecem, nesses mesmos jornais, editoriais em 
defesa das tradições. Na matéria Alegrias populares, de 5 de janeiro de 1912, o jornalista do Diário de Notícias criticava os políticos que deixavam a população passar o ano inteiro "sem lar higiênico, sem pão, sem conforto, sem alegrias salutares, sem expansões ruidosas e comunicativas" e, no período das principais festas religiosas populares, queriam substituí-las por hábitos e manifestações europeias e americanas. Afirmava que o povo que esquece as suas festas religiosas, patrióticas e seus festejos de rua, substituindo-os pelo que aporta das terras estrangeiras, "é um povo cujas características, se não estão mortas, ao menos estão prestes a morrer". E acrescentava:

Que desapareça, cedendo lugar, o que existe de inconveniente, de triste, de mau, de atrasado, de anti-progressista, todos concordam. Porém, que se substituam os inocentes folguedos de origem indígena, por outros de igual jaez, vindos de fora, que os nossos hábitos de gente limpa e asseada, quer física, quer moralmente, venham abater os hábitos europeus e americanos, tudo sem melhor vantagem comum, sem melhor utilidade prática, isto não, não podemos, não devemos consentir. (ALEGRIAS..., 1912)

Percebe-se, assim, que a modernização não era uma via de mão única. Os baianos eram atraídos pelas reformas urbanas de São Paulo e Rio de Janeiro, saudavam as transformações como marcas da modernidade e civilidade, mas também queriam manter seus hábitos e costumes.

É interessante notar que a Bahia acatava modelos de modernidade, mas também atraía sujeitos de outras cidades pelo crescimento econômico, riqueza do patrimônio artístico e cultural, clima agradável e belezas naturais. A atração exercida pelo comércio nem sempre era vista de forma positiva. Os comerciantes vindos de outros lugares do país, inclusive das cidades que lhes serviam de modelo, eram recebidos com receio. Muitas vezes foram designados de forasteiros, aproveitadores, indesejáveis usuários 
de um sistema administrativo duvidoso, como revela o jornal $A$ Tarde em matéria intitulada $A$ remodelação e os negocistas de 19 de outubro de 1912:

Entretanto, em meio a essa procela de trabalho eficaz e produtiva, há alguma coisa que é preciso combater: é o julgamento que fora daqui se está formando dos processos administrativos por que se vão realizando as grandes obras. Não é preciso milagre de argúcia para surpreender, com magos, a falsa opinião. Basta notar a imigração de sujeitos escunhoados (sic) e maneirosos, todos lábias e ademanés (sic), que nos chegam por cada paquete, principalmente do Rio, para se ter a idéia de que a Bahia está considerada como um campo de bons e belos negócios, de contatos fáceis e rentosos que a advocacia administrativa não encontra empecilhos para conseguir.

É contra esse aspecto do movimento reformista que muitas vezes protestamos com razão, por que obra tão benemérita deve ser intangível até das suspeições de desonestidade.

Havia, portanto, uma preocupação com a imagem da Bahia diante de outros Estados e países. O progresso era bem-vindo, mas era preciso ter prudência com a honestidade nas relações comerciais, "com o julgamento" que sujeitos de outras praças poderiam fazer dos processos administrativos.

\section{PERMANÊNCIA DOS COSTUMES}

Os habitantes de Salvador receberam o regime republicano ainda com muitos contrastes, promovendo inovações, mas também tendo que conviver com muitas permanências nem sempre indesejáveis. Apesar das intervenções urbanas e culturais realizadas no auge da modernização, no governo de J. J. Seabra, muitas características e referências dos tempos do Império ainda 
são perceptíveis na arquitetura e nos hábitos dos baianos. Caymmi canta que "nas sacadas dos sobrados da velha São Salvador" permanece "a lembrança de donzelas do tempo do Imperador". Permaneceram também nos largos, praças e avenidas as rodas de samba e capoeira; os vendedores de comida afro-baiana, especialmente as baianas com seus tabuleiros de acarajé, abará, bolinho de estudante, cocada e outros quitutes; as procissões e cortejos religiosos repletos de ícones do Catolicismo e do Candomblé e devotos animados pela música, dança e fogos de artifício.

A campanha contra os fogos não surtiu os efeitos desejados. Os fogos de planta, condenados por serem perigosos à população e cuja fumaça escondia a beleza das ruas remodeladas e ofuscava a iluminação elétrica, foram aos poucos substituídos pelos fogos de ar e artifício, mas não desapareceram completamente, pois continuavam fazendo parte das noites de festas aos santos, pelo menos nos arrabaldes.

É verdade que alguns divertimentos populares muito comuns nas festas religiosas não acompanharam a modernização. Das ruas e avenidas remodeladas desapareceram os "folguedos provincianos", expressão utilizada pelo cronista Antônio Vianna para se referir ao quebra-pote, pau de sebo e carrossel e às corridas de saco. Porém, assim como os fogos, essas brincadeiras ainda ocupavam os recantos da cidade. Vianna lamentava as mudanças "impostas pelo progresso", especialmente dos bailes e saraus que nas casas particulares animavam as datas do calendário religioso:

Os saraus domésticos a piano, algumas vezes, e, na maioria, aos compassos de um terceto musical, formado por conhecidos festeiros, que tocavam por divertimento, de graça. Os sambas e batuques nas praias, por detraz (sic) das barracas, no fundo das casas, nas cozinhas com o conhecido estribilho: SAMBA NA COZINHA SINHÁ NÃO QUER! [...] (VIANNA, 1950, p. 22) 
Entretanto, é preciso observar com atenção o saudosismo do cronista. Vianna frequentava os bailes e saraus da elite e tudo indica que eles não desapareceram em função das reformas urbanas. São formas de divertimentos datadas. Eram realizados até as primeiras décadas do século XX inclusive porque Salvador não oferecia tantas outras diversões. As igrejas e as casas das famílias abastadas eram espaços privilegiados de sociabilidade; porém, a chegada do cinema e a difusão dos clubes abriram novas possibilidades para os encontros da elite. É importante ressaltar, na fala de Vianna, os espaços ocupados por sambas e batuques: as praias, o "fundo das casas" e das barracas. As rodas de samba e capoeira, apesar de indesejáveis por suas referências africanas, resistiram ao tempo e às intervenções, ganharam as ruas, os largos e adros das igrejas.

O cheiro do azeite de dendê que inundava a cidade, tantas vezes criticado como hábito não civilizado, não deixou de fazer parte das festas religiosas nos terreiros de Candomblé e também nas barracas de comida e bebida montadas nos largos em frente às igrejas nos dias das festas católicas. Os membros da elite baiana, adeptos dos ideais de civilidade e modernização, poderiam não admitir que devorassem com prazer os pratos da culinária afrobaiana, mas não foram capazes de acabar com esse costume. As "mulheres de saião", alheias às modernidades, atravessam a cidade vendendo suas iguarias.

Enfim, os melhoramentos na arquitetura urbana, na limpeza e saúde pública eram desejados pela elite intelectual e também pela população humilde. Porém, quando se tratava da mudança de costumes, havia uma persistência da tradição. Afinal, considerava-se que Salvador, apesar dos seus muitos defeitos, possuía a virtude de ser um dos poucos espaços no território brasileiro a valorizar suas tradições. Portanto, poderia seguir os exemplos de modernidade de Paris, Rio de Janeiro e São Paulo, mas deveria manter 
as características de primeira capital do Brasil, principalmente as manifestações culturais herdadas dos colonizadores, índios e escravos africanos que representavam a nacionalidade e deveriam ser mostrados aos visitantes.

\section{REFERÊNCIAS}

ALEGRIAS populares. Diário de Notícias, Salvador, 5 jan. 1912.

AVENIDA para inglês ver. A Tarde, Salvador, 22 out. 1912.

BARBOSA, Manoel de Aquino. Efemérides da freguesia de nossa Senhora da Conceição da Praia. Salvador: Beneditina, 1970.

BENJAMIN, Walter. Paris, capital do século XIX. In: KOTHE, Flávio R. (Org.). Walter Benjamin - Sociologia. São Paulo: Ática, 1985. p. 30-43.

CARIBÉ. As sete portas da Bahia. São Paulo: Martins, 1969.

COUTO, Edilece Souza. Festejar os santos em Salvador: tentativas de reforma e civilização dos costumes (1850-1930). In: BELLINI, Lígia; SOUZA, Evergton S.; SAMPAIO, Gabriela dos R. (Org.). Formas de crer: ensaios de história religiosa do mundo luso-afro-brasileiro, séculos XIV-XXI. Salvador: Edufba; Corrupio, 2006. p. 273-297.

SALVADOR. Prefeitura Municipal. Conselho. Do entrudo, máscaras e confetti, espetáculos e fogos de artifícios. In: LIVRO de registro de posturas. Salvador, 1920. cap. 21, p. 17-84.

COSTA, Ângela M. da; SCHWARCZ, Lilia Moritz. 189o-1914: no tempo das certezas. São Paulo: Companhia das Letras, 2000. (Virando Séculos).

OS DESMORONAMENTOS: avisos do destino. Diário de Notícias, Salvador, 12 out. 1912.

DIÁRIO DE NOTÍCIAS. Salvador, 22 jun. 1912.

EDITORIAL. Diário de Notícias, Salvador, 9 dez. 1912.

FERNANDES, Ana; GOMES, Marco Aurélio de Filgueiras.

Idealizações urbanas e a construção da Salvador moderna: 18501920. In: . (Org.). Cidade e história. Salvador: Faculdade de Arquitetura / ANPUR, 1992. p. 53-68. 
FOGOS soltos. Diário de Notícias, Salvador, 22 jun. 1912.

MATTOSO, Kátia. Bahia: a cidade do Salvador e seu mercado no século XIX. São Paulo: HUCITEC, 1978.

NO REINO do fetichismo: abusões e contágios. Diário de Notícias, Salvador, 30 de nov. 1920. p. 1.

REIS, João José. Batuque negro. In: JANCSO, István; KANTOR, Íris (Org.). Festa: cultura e sociabilidade na América Portuguesa. São Paulo: Hucitec; Edusp, 2001. v.1, p. 339-358.

A REMODELAÇÃO e os negocistas. A Tarde, Salvador, 19 out. 1912. PEIXOTO, Afrânio. Breviário sobre a Bahia. Rio de Janeiro: MEC, 1980.

ROSADO, Rita de Cássia S. de C. A “Cidade Porto” e a Alfândega Provincial, século XIX. História da Bahia - Revista da Fundação Pedro Calmon. Salvador, n. 8, p.n8-12, dez. 2004.

SANTOS, Mário Augusto da S. Novas e velhas ocupações na Salvador republicana (1890-1930). In: FERNANDES, Ana; GOMES, Marco Aurélio de F. (Org.). Cidade \& história. Salvador: Faculdade de Arquitetura / ANPUR, 1992. p. 257-262.

EM TORNO dos melhoramentos. Diário de Notícias, Salvador, 25 jun. 1912. p. 1.

VIANNA, Antônio. Casos e coisas da Bahia. Salvador: Museu do Estado, 1950.

\section{Fontes manuscritas}

Arquivo Histórico Municipal de Salvador - AHM.

Códigos de Posturas do Município da Cidade do Salvador.

Livros de Registro de Posturas - 1897, 1901, 1920 e 1929.

\section{Fontes impressas}

Instituto Geográfico e Histórico da Bahia - IGHB.

Jornais leigos:

A Tarde (1912, 1914, 1916).

Diário de Notícias (1912,1915, 1920). 


\section{O oriente é aqui}

o cortejo de referências fantásticas de outros mundos no Carnaval de Salvador

MILTON MOURA 


\section{INTRODUÇÃO}

A observação da História do Carnaval de Salvador permite identificar a força de diferentes referências fantásticas, correspondendo a regiões imaginadas que guardam relação com especificidades dos grupos que as cultivam.

No último quartel do século XIX, as famílias das elites mais claras e esclarecidas procuravam seguir o modelo do Carnaval europeu antitético às práticas que passavam a se chamar, genericamente, de Entrudo. Tal modelo era emblematizado no uso das máscaras, nos corsos e nos desfiles das grandes sociedades. Nessa mesma época, o que se poderia chamar hoje de uma emergente classe média negra conseguia, mediante dramáticas negociações com as elites dirigentes e seus delegados, levar à rua motivos africanos.

Por sua vez, o povo mais escuro, pobre e descalço fazia suas batucadas nas cumeeiras de bairros pouco afastados, como Garcia, Tororó e Brotas, nos fundos dos vales (onde estão hoje as grandes avenidas) e na Baixa dos Sapateiros, participando perifericamente 
do Carnaval. Pequenos grupos de foliões serpenteavam pelos interstícios da descontínua malha urbana de Salvador, somando-se pouco a pouco, parando para comer e beber em casa de amigos e conhecidos.

A partir dos anos 30, tanto o repertório do rádio inundou a festa soteropolitana com marchinhas e sambas cariocas como o repertório do cinema abasteceu inúmeros blocos com imagens e referências de um mundo maravilhoso que misturava diversos ícones sob o signo do orientalismo. Do porto, vinham boleros, salsas, merengues e tangos, inclusive, através das radiolas dos marinheiros - dentre estes, sobressaíam-se os norte-americanos. A partir dos anos 50, as revistas impressas, o cinema e, mais tarde, a televisão aportariam novas modas, que encontrariam em diferentes modelos de bloco a realização de novas referências fantásticas, como o farwest e o afro. O Carnaval de Salvador pode ser lido, assim, como um cortejo de diferentes mundos imaginados, no qual as velhas formas perdem espaço ou visibilidade progressivamente diante das mais recentes. Eis a postura básica desta contribuição: tomar o Carnaval de Salvador como palco em que se pode assistir, entre outros dramas, à relação que a cidade vem estabelecendo com o mundo.

Como pensar o fascínio que a descoberta e apropriação de ícones de outros mundos exerceram sobre os sujeitos que fizeram o Carnaval de Salvador nesse período? Que relações é possível identificar entre as formas com que se organizaram os carnavais de então e as representações sobre a relação entre a cidade e os mundos aí presentes, que por sua vez configuram relações de identidades e alteridades? Daí podemos desdobrar a problemática: como e em que sentido podemos afirmar que o Carnaval de Salvador nesse período organiza e expressa representações sobre a relação entre cidade e mundo(s), oportunizando, em linguagem festiva e alegórica, representações sobre identidades e alteridades? 
Esta apropriação contínua de iconografias de outros mundos, que tinha no Carnaval seu momento máximo, é um fator relevante na configuração da cidade do Salvador, pelos seus moradores como pelos outros, como um lugar aberto para o mundo?

Trata-se, então, de reconstituir algumas dessas recriações de outros mundos, destacando a fantasia propriamente dita, elemento onírico que organiza e confere sentido ao elemento supostamente mais real da existência. Em virtude da limitada extensão do texto, uma mirada sobre período tão vasto não pode não ser panorâmica; além disso, demanda a aproximação da lente do pesquisador em um período mais nuclear, quando se pode observar o tráfico fantástico no Carnaval de Salvador ocorrendo com mais nitidez e intensidade; neste caso, aquele que se estende entre os anos 50 e os 80 .

\section{INVERSÃO, DESCONTINUIDADE, FANTASIA}

A discussão teórica central nesta contribuição se dá com alguns autores referenciais no âmbito da história do Carnaval e da festa; o conceito mais intrigante parece ser o de inversão, que aparece explicitamente em diversos momentos da reflexão desses interlocutores.

Um conceito fundamental no tratamento do Carnaval por Bakhtin (1993) é o de cultura cômica popular. O autor ressalta incessantemente sua infinitude e heterogeneidade, o que se plasma magnificamente nos textos de Rabelais, no século XVI. São inúmeras as referências ao caráter ou essência da cultura carnavalesca, que residiria sobretudo no renascimento contínuo e na renovação, e não na tradição como algo que simplesmente se preserva. Tratase da segunda vida da cultura medieval ou segunda vida do povo, baseada no princípio do riso. 
O riso, realização plena da comicidade, expressão mais forte e mais pura do espírito carnavalesco medieval, é o traço mais acentuado na descrição das cenas rabelaisianas de que parte Bakhtin. A própria reversibilidade dos processos vitais, contrapartida biológica da inversão, está associada à experiência do riso, como desconstrução da verdade sisuda atribuída à natureza. Rir já seria, por si, opor-se à cultura oficial, à atmosfera séria, pesada, da civilização feudal. A fantasia - na acepção de traje - é para Bakhtin (1993) a renovação simultânea da roupa e da máscara social. Neste sentido é que se compreende, também, a permutação do superior e do inferior na hierarquia, quando o bufão é coroado rei.

A afirmação mais frequente nos textos que se referem diretamente ao carnavalesco é o poder que têm as festas populares - sobretudo o Carnaval, que as recapitula histórica e conceitualmente - de manifestar a reversibilidade entre a vida e a morte, o novo e o velho. É provável que nenhum outro item do seu pensamento seja tão controvertido e malversado quanto este. Algumas expressões da obra sobre Rabelais tornaram-se paradigmáticas para a discussão sobre inversão e mudança, tanto no âmbito da teoria literária como naquele nas ciências sociais. É o caso de "o mundo às avessas”. A reversibilidade entre a morte e a vida - a permanente vitória da vida, constantemente recriada - é a razão nuclear da alegria característica do carnavalesco.

O grotesco carnavalesco faz sentido enquanto inventividade, associando elementos heterogêneos e aproximando polos distantes, libertando-se assim dos hábitos convencionais. É como uma lente que permite mirar o mundo diferentemente, relativizar sua ordem instituída e, sobretudo, intuir e formular a própria possibilidade de uma ordem diferente daquela que se experimenta como regra. Mostra um mundo inteiramente outro, uma ordem diversa, relativizando a imobilidade aparente das formas experimentadas na estética convencional. Bakhtin vê aí a tendência e o 
desejo de retornar, pela via da carnavalização, aos tempos áureos de Saturno.

Ambivalência, revés, inversão, incompletude, relatividade, transformações, metamorfose, alternância, renovação, avesso, permutação... designação numerosa para o devir carnavalesco. Este é, sem dúvida, o aspecto de sua obra mais conhecido entre nós. Há, contudo, o contracanto desta ode ao revés. Trata-se daquilo que poderíamos chamar de acomodação entre o reverso e o seu próprio verso, entre o avesso e o direito.

Bakhtin (1993) diferencia radicalmente a festa medievalrenascentista e a festa moderna quando afirma que o século XVI assiste ao clímax e declínio da cultura carnavalesca, que perde seu caráter público, vendo diminuir seu papel na vida cotidiana e se empobrecerem suas formas. O próprio contato familiar ordinário estaria muito distante daquele tipo de convivência que se estabelecia em praça pública durante o Carnaval. Faltaria justamente o caráter universalista, o clima totalizante da festa e a concepção profundamente carnavalesca da vida.

O Carnaval é o tempo alegre, da relatividade, da ambivalência, experimentado como um tempo leve, associado à ligeireza. Este tempo alegre é completado com a noção de relatividade. Daí a importância da máscara, inclusive como estratégia no sentido de relativizar os polos dos binômios existenciais como morte/ vida, velhice/infância, cotidiano/fantasia, etc. Quando uma festa popular tradicional decaía ou desaparecia, suas máscaras se refugiavam no Carnaval, passando a ser, neste sentido, carnavalescas. O próprio Carnaval, como evento, é um desaguadouro de máscaras, brincadeiras, gozações, efígies, etc. de outras festas, constituindo-se como acervo em que se mantinham as formas que não apresentavam mais figuração própria, vindo também a ser chamadas Carnaval. 
Quando discorre sobre o sentido do Carnaval, ao falar da experiência da unidade popular, o autor diz que o corpo individual, no todo vivenciado na festa, deixa até certo ponto de ser a si mesmo, inclusive mediante uma dinâmica de máscaras. Somente com as máscaras do bufão e do bobo foi possível revelar o humano no que tem de mais íntimo. Somente o (literalmente) excêntrico tem a força de fazer passar ao mundo da visibilidade, em que os traços se organizam em perfis, o que está oculto, reprimido, velado. Estes personagens nos franqueiam a passagem ao humano sufocado nos papéis oficiais. É a exotopia radical que nos permite ver a nós mesmos, em contrapartida.

Outro autor fundamental para a construção da metodologia deste trabalho é Julio Caro Baroja $(1965,1985)$. Não se encontra em seus escritos a expressão "inversão carnavalesca”; entretanto, enfatiza-se aí a dimensão desta festa como a ocasião em que os mais pobres viam-se realçados. Os servos, doentes, desvalidos, enfim, os periféricos ocupavam o centro da cidade com humor e desenvoltura, o que seria impossível em outro momento.

No que diz respeito à passagem do Carnaval medieval-renascentista para o moderno, a contribuição de Baroja coincide em vários aspectos com aquela de Bakhtin. Diferentemente deste último, entretanto, Baroja insiste na singularidade do traço carnavalesco em cada época e mesmo de cada lugar. O que lhe parece mais geral é o caráter de rito de calendário; o Carnaval é uma herança da temporalidade cristã medieval e nisto reside sua força enquanto erupção daquilo a ser disciplinado em outras épocas do ano.

Na Idade Média, na Renascença, no Barroco, no Romantismo... Em cada época, o Carnaval encenaria formas diferentes de mudar o cotidiano. Para ambos os autores, o tempo carnavalesco é aquele da alegria, do diferente, incompatível com a racionalização moderna. Com a imperiosidade da razão, teriam se acabado os exageros e turbulências e, com isto, o encanto da festa. Comen- 
tando o esforço da Prefeitura de Madri no sentido de ressuscitar o Carnaval, nos anos 8o, Baroja se mostra radicalmente cético. O espírito do Carnaval não sobrevive no meio propriamente urbano, não pode florescer em meio à racionalidade técnica e produtivista, que padroniza inclusive o "bom gosto". O autor descrê da simples possibilidade de o Carnaval vicejar em grandes cidades, em virtude do controle do Estado e outras instâncias repressoras sobre o comportamento das pessoas, sobretudo no que diz respeito à invenção explosiva e hilariante do inédito e do cômico.

Tomemos também Peter Burke (1989), que encontra nos séculos XVIII e XIX praticamente os mesmos estilos de festa que esses autores preferiram circunscrever ao período medievalrenascentista. Mesmo assim, coloca já desde o século XVI a tensão entre o vetor do Carnaval, que podemos entender como realização do que Bakhtin chama de cultura cômica popular, e o vetor da Reforma, que podemos ler, em contrapartida, como definição dos padrões estéticos e morais da modernidade. Aponta uma tipologia diversificada na atuação dos agentes reformadores e modernizadores e considera o Carnaval o alvo predileto dos guardiões dos bons costumes. As festas que continham elementos da tradição popular cristã eram acusadas de deturpação, irreverência ou infidelidade. Havia um cuidado especial em separar drasticamente sagrado e profano, seguindo-se uma infinidade de prescrições, proibições e mutilações de formas populares de lazer e religião. Os reformadores - católicos e protestantes - declaram guerra ao Carnaval, sendo muito significativo aquilo do que o acusam: desperdício, volúpia, lascívia, preguiça, culto ao supérfluo.

Burke (1989) lembra que, em algumas cidades, podia-se dizer impunemente qualquer coisa durante o Carnaval. Em várias delas, o Carnaval estendia-se desde as festas do Natal até as vésperas da Quaresma. As pessoas se fantasiavam com trajes coloridos, pesados e mesmo incômodos, inclusive travestis. Nas ruas principais 
de várias cidades, usavam-se carros alegóricos. O autor evidencia a preponderância de três temas carnavalescos principais: a comida, o erotismo e a violência. Abundavam as letras de canções com duplo sentido, bem como alegorias fálicas em máscaras, carros e imagens. Falava-se aberta e jocosamente dos maridos traídos e espancados pelas esposas. Brigava-se e matava-se mais que de costume.

Enfim, relaxavam-se as normas da vida cotidiana normal, vivenciando-se um período de permissividade e tolerância. O Carnaval não apenas opunha-se à Quaresma; era a antítese da vida cotidiana durante o resto do ano. $\mathrm{O}$ autor retoma a noção de carnavalização de procedimentos como as execuções de criminosos ou o castigo público dos acusados de bruxaria. Estas colocações levam a relativizar o alcance da inversão carnavalesca, tema tão caro a Bakhtin. Por outro lado, os historiadores mostram como certas formas de protesto terminam transpondo a vigilância e a repressão, donde a proibição, em circunstâncias mais tensas, do Carnaval e das festas religiosas. Ou seja, as próprias elites viam que as manifestações populares não estavam apenas no campo do simbólico. Um número considerável de revoltas aconteceu por ocasião da Terça-Feira Gorda e de festas religiosas, como também observou Natalie Davis (1990).

Podemos verificar, na historiografia, como as elites modernas procuram cercar a festa, o Carnaval, o folguedo, o teatro popular - enfim, a cultura lúdica tradicional - procurando restringir seu alcance e, precisamente, sua duração e sua frequência. Isto é importante aos efeitos de compreender melhor as dimensões do Carnaval. No caso do Brasil do século XIX, tanto os viajantes que nos presentearam com suas crônicas como os representantes das próprias elites brasileiras dão testemunho da contradição que lhes parecia a própria extensão temporal das práticas musicais e coreográficas dos negros. Não seria festa em demasia, seja em quantidades, seja em qualidades? 
Le Roy Ladurie (1979) também pode ser tomado como paradigma desta reflexão. Trata-se de um estudo de caso do Carnaval de Romans, uma pequena cidade ao pé dos Alpes franceses, em 1580. O autor toma como pano de fundo de toda a narrativa a extraordinária tensão entre os diversos setores sociais naquela região, no final do século XVI. O campo se revolta contra a cidade, mas também os plebeus se revoltam contra os privilegiados e os católicos tentam deter os huguenotes.

Cada setor social costuma organizar, nestas ocasiões, a reynage, festa popular em que se elege um rei. Não é difícil perceber o quanto isto está próximo dos rituais carnavalescos de inversão... O rei eleito em 1579 é um mestre/artesão. A confrontação dos poderes locais se visualiza com todas as arestas na capacidade extraordinária de aglutinação do rei carnavalesco de Romans entre os mais pobres. O clima é de franca hostilidade. As lutas contras os bandidos se avolumam, incluindo numerosas matanças, incêndios, fome e toda sorte de privações. O Terceiro Estado se polariza entre as oligarquias urbanas, os artesãos e os camponeses. Às vésperas do Carnaval, a cidade é um caldeirão fervilhante. Sucedem-se as "greves", relacionadas às dívidas de impostos majorados, envolvendo setores como os açougueiros, vinhateiros, padeiros e leiteiros. Sua expressão inclui cortejos impressionantes, celebrações da emulação crescente, configurando um clima de permanente desafio.

Mais que os outros autores, Ladurie incorpora o instrumental estruturalista de análise socioantropológica, acentuando as manifestações de inversão na coreografia, na música, nos trajes e nas expressões plásticas, sobretudo as máscaras. Organizam-se diversos grupos, chamados reinos. O reino do galo de terreiro, da perdiz, da lebre e do galo capado, que se somam ao reino do carneiro, já tradicional. Para Ladurie, como para Bakhtin, o Carnaval pode ser lido como uma imitação minuciosa dos ritos da 
realeza no contexto do ciclo cosmológico das celebrações pagãs cristianizadas. O reino da lebre é dos huguenotes e também, de certa forma, dos artesãos; o da perdiz, dos notáveis católicos; o do galo capado, dos artesãos e camponeses; este é oposto ao da perdiz, católico e papista. Na véspera da Terça-Feira Gorda, são dois os Carnavais na mesma cidade: um deles capitaneado pela águia, pelo galo e pela perdiz, animais nobres, associados à virilidade, habitando os ares, logo superiores; o outro caracterizado por animais terrestres e vulgares, como a lebre (de mau agouro), o carneiro e o capão... passando pela mediação do urso. Na noite da véspera da Terça-Feira Gorda, a perdiz passa a matar o capão, eliminando bruscamente o líder popular. A águia e a perdiz passam em cortejo triunfante para realizar um baile em ambiente privado. Espalha-se o terror pelos arredores rurais de Romans.

Segundo Ladurie (1979), o Carnaval de Romans lançou mão abertamente da fórmula das reynages e tem suas raízes na tradição católica paroquial da época. Deixando de ser uma festa fundamental ou exclusivamente agrária, o Carnaval se constitui como palco em que se expressam os conflitos sociais, aportando uma gramática simbólica com que se pode dizer a desigualdade e o descontentamento, donde a polarização verificada na experiência de Romans. O Carnaval da pequena cidade ocasiona a expressão de várias polarizações, participando assim da dinâmica de movimentos sociais. O tema da inversão carnavalesca recebe de Ladurie (1979) uma contribuição que permite alargar o paradigma bakhtiniano: o Carnaval é mais que uma inversão dualista momentânea da sociedade, com o sentido de justificar sua normalidade. O recurso aos animais como máscaras totêmicas, bem como outras estratégias artísticas, permite expressar, pela gramática da diversidade zoológica, a própria diversidade e complexidade da sociedade dos homens.

Em Bakhtin, inversão é botar o mundo pelo avesso, tal como aponta a literatura medieval e renascentista, sobretudo Rabe- 
lais. Em Baroja, é representar o mundo tendo no centro aqueles que normalmente aí não estão. Já Ladurie tem uma abordagem mais política e localizada, desenvolvendo um estudo de caso. A interlocução com estes autores se orienta propriamente como uma intrigação, posto que, para Bakhtin, a inversão carnavalesca não acontece mais no século XX e, para Baroja (1965), o próprio Carnaval acabou.

Ora, nossos autores referem-se sempre a formas carnavalescas anteriores ao século XX. Encontro razões para pleitear que a construção do conceito de inversão na obra desses autores pode ser reconfigurada como descontinuidade do cotidiano. Tal descontinuidade, por sua vez, pode tornar o cotidiano tão desvelado e nu que, aos seus próprios sujeitos, só pode existir transfigurado como numa alegoria, através da assimilação, identificação ou incorporação de referências fantásticas. $O$ fantástico descontinua a vida considerada normal através da apropriação de elementos de outros mundos. É nesta perspectiva que tomo as contribuições acima, voltando seus recursos interpretativos para o estudo do Carnaval do século XX em uma cidade como Salvador.

\section{A FANTASIA NO CARNAVAL DE SALVADOR}

A historiografia do objeto desta reflexão, de modo geral, é modesta. Nos últimos vinte anos, um número expressivo de pesquisas históricas tem sido desenvolvido sobre o Carnaval de Salvador, especialmente no que diz respeito à afirmação de grupos que se identificam como negros. Percebe-se, contudo, uma lacuna no que concerne à formação histórica das referências fantásticas do Carnaval de Salvador em sua diversidade. Parte considerável de outras experiências de criação carnavalesca anteriores aos anos 80 ainda não foi colocada como objeto de pesquisa. 
Os pontos de corte do período realçado neste texto são o despertar do afoxé Filhos de Gandhi, inaugurando uma linguagem carnavalesca, em 1949, e o sucesso da banda Pimenta de Cheiro, com o bloco Cheiro de Amor, no final dos anos 1980. A chave de sua compreensão é a consideração comparada das referências fantásticas, tanto na sua diversidade como naquilo que nos permite unificá-las num texto: um metacortejo fantástico de mundos. Trata-se de identificar como diversos grupos que fizeram o Carnaval nesse período reconstituíram os seus e outros mundos na forma de uma iconografia carnavalesca. Constrói-se assim o metacortejo no plano metodológico. É o olhar do pesquisador que alcança a diversidade das formas musicais, coreográficas e plásticas como uma unidade do cortejo de cortejos, tanto em termos sincrônicos quanto diacrônicos, resultando na percepção de um cortejo múltiplo. A própria sucessão do Carnaval no espaço de quatro décadas demanda uma estratégia de captura de seu sentido enquanto elaboração estética de alteridades e diversidades. Esta metodologia guarda, portanto, proximidade com a construção weberiana dos tipos ideais.

Vamos então ao metacortejo, acentuando a importância de algumas experiências.

A partir de 1870, os membros do grupo carnavalesco Cavaleiros da Noite passaram a frequentar uniformizados os bailes de Carnaval, no que foram seguidos por vários outros. Os cortejos das elites seguiam o modelo que, no final do século XIX, tinha em Nice sua referência máxima ${ }^{1}$. Já os bailes de máscaras remontavam explicitamente ao modelo de Veneza. Pelas ruas, circulavam os foliões mais pobres e mais escuros, em batucadas que a imprensa da época chamava frequentemente de Entrudo.

1 O modelo de Nice como emblema do Carnaval moderno é cuidadosamente estudado por Felipe Ferreira (2005). 
Em 1883, teve início o Carnaval do Fantoches da Euterpe, então um clube de elite. No ano seguinte, já se fazia o cortejo do carro de ideia, novidade seguida pelos grupos semelhantes. O destaque do Carnaval passava a ser o luxo dos préstitos e, em versão mais modesta, das pranchas, que podiam não passar de um tablado de madeira com alegorias temáticas deslizando sobre os trilhos do bonde. As ruas da Cidade Alta eram domínio das grandes sociedades, sendo as mais brilhantes o Fantoches da Euterpe e o Cruz Vermelha, seguidos pelo Innocentes em Progresso, Tenentes do Diabo e Democrata. Os jornais não poupavam elogios a essas sociedades, ao tempo em que criticavam a presença de foliões "sujos" e "maltrapilhos" pelas ruas. Seu repertório era composto de marchinhas e operetas. O Fantoches chegou a executar a abertura da ópera Aída, de Verdi, no início do cortejo. No mais, a apresentação do corso não era muito diferente do que se via nos bailes dos clubes das boas famílias. As fantasias eram usadas fundamentalmente para serem vistas, sendo que algumas delas inviabilizariam a dança.

Todos os autores que se debruçaram sobre este período atestam a ligação estreita entre afoxé e Candomblé. Vejamos o que dizem sobre o afoxé os eminentes Nina Rodrigues e Edison Carneiro:

O seu sucesso popular está em constituírem eles verdadeiras festas populares africanas [...] compacta multidão de negros e mestiços que a ele, pode-se dizer, se haviam incorporado e que o acompanhavam cantando as cantigas africanas sapateando as suas danças e vitoriando os seus ídolos ou santos que lhes eram mostrados no carro do feitiço. Dir-se-ia um candomblé colossal a perambular pelas ruas da cidade. E de feito, vingavam-se assim da polícia, exibindo em público a sua festa. (RODRIGUES, 1977, p. 182)

[...] esse estranho cortejo de negros que tocam atabaques e entoam canções em nagô, em louvor das divindades do Candomblé. (CARNEIRO, 1991, p. 101) 
No final do século, encontramos já os blocos de negros organizados como préstitos e grandes sociedades. Raphael Vieira Filho (1995) lembra que esses grupos eram também chamados afoxés, mas não lhes agradava ser chamados de tribais ou candomblés. Referiam-se aos mouros, aos egípcios e aos etíopes - guerreiros africanos gloriosos, não associados à escravidão ou à pobreza. Os mais fortes eram a Embaixada Africana, de 1895, e os Pândegos da África, de 1897, ambos de cortejo “bem organizado”, sem nada que desabonasse a ordem e o asseio dos associados. Eram negros candidatos a cidadãos de uma Bahia de bons costumes, bem comportada... Tanto quanto para os préstitos da burguesia, era importante a pompa no cortejo, bem como a alegoria da elegância e da limpeza. A busca do luxo na expressão carnavalesca levou a Embaixada Africana a ostentar um carro de madrepérola trazido de Paris.

Com o advento do rádio, a temática da nacionalidade brasileira associada ao samba legitima recursos estéticos de origem africana, que passam a povoar os bailes das elites, como instrumentos e pontos de samba. Em 1918, o bloco Troça Carnavalesca Mamãe em Romaria leva uma cantiga para Oxalá à rua. Enquanto isto, o maxixe era adotado pelas famílias de classe média, desbancando a polca e outros gêneros, e chegava a ser adotado em algumas pranchas.

Não é comum atentar para a importância da manutenção e renovação de contatos comerciais e culturais entre a Bahia e o continente africano após o final da escravidão. Não somente o que se passava no Golfo de Benin repercutia no Recôncavo, como os acontecimentos políticos mais destacados em outras regiões africanas, entre elas a Etiópia. Um documento da Embaixada Africana se refere a vários reinos de África, que desfilam orgulhosamente numa cena simétrica àquela dos préstitos dos moradores mais claros da cidade do Salvador. (VIEIRA FILHO, 1995) É outra par- 
te do mundo que chega, num confronto alegórico de referências identitárias, da mesma forma como as elites de pele clara traziam os préstitos de Nice para o cortejo na Avenida Sete.

Ora, nas décadas de 20 e 30, temos o estabelecimento do samba como o ritmo brasileiro por excelência. Na complexa dinâmica de organização do texto da identidade brasileira no Rio de Janeiro, então, são aproveitados elementos de origem africana num padrão mais "civilizado", o que significa moldes que possam aparecer receptivos diante das elites mais claras.

Pequenos grupos carnavalescos aparecem aqui e ali nos registros da imprensa e nas memórias de antigos foliões. Anísio Félix e Moacir Nery (1994) chegam a elencar vários deles só no bairro do Garcia, como As Cozinheiras e As Gueixas. Em 1937, o grupo Gueixas em Folia, do bairro do Binóculo, solicitava à prefeitura dinheiro para uma gambiarra, necessária para abrilhantar seu grito de Carnaval.

Os mesmos anos 30 viram o aparecimento das caretas nas ruas da Cidade Alta, na hora dos desfiles das grandes sociedades. Não mais os máscaras de que fala Nina Rodrigues (1977), com figuras grosseiras e artesanais; temos agora máscaras simétricas, de "boa aparência", ou mesmo aterrorizantes, mas sem a conotação de pobreza ou sujeira. Em grupos uniformizados ou solitários, os mascarados enchiam as ruas de movimentos, com fantasias de tecidos brilhantes e coloridos e guizos barulhentos. $\mathrm{O}$ aparecimento dos mascarados acontece em ondas; dos anos 50 aos 80, voltam a aparecer as máscaras artesanais, ao lado daquelas de fabricação industrial.

O repertório mais cantado passava a ser aquele divulgado pelo rádio, ou seja, as marchinhas do Carnaval carioca; alguns sucessos ficavam por anos ou décadas. O predomínio das marchas de Carnaval, em andamento variável, manter-se-ia até a disseminação do trio elétrico, nos anos 60. 
As novidades em termos de modelos organizacionais carnavalescos começaram a se tornar visíveis no final dos anos 40. Em 1949, temos o aparecimento do afoxé Filhos de Gandhi, formado, na sua maioria, por trabalhadores do porto e fortemente vinculado à sociabilidade desenvolvida em torno das docas. Algumas de suas fantasias eram feitas com lençóis cedidos pelas prostitutas que exerciam sua profissão na Ladeira do Julião. O ritmo levado pelo Gandhi, o ijexá, é praticado na liturgia de vários orixás, sendo emblemático de Oxum - um toque lento e harmonioso, ao qual corresponde uma coreografia de gestos delicados, bem distante de um golpe.

De acordo com depoimentos recolhidos por Anísio Félix (1987) junto aos fundadores e outros líderes, ao mesmo tempo em que o Mahatma Gandhi era admirado pela sua militância política, a temática orientalista se estabeleceu em virtude do impacto dos filmes que divulgavam motivos orientais. No verão de 1948-49, fazia sucesso em Salvador o filme Guga Din², que, segundo esses mesmos depoimentos, detonou a formação de um afoxé... de contornos orientalistas.

Os Filhos de Gandhi são o mais conhecido de uma legião de blocos que se formaram em torno de uma categoria profissional; no mesmo período, outros doqueiros formaram os Filhos do Porto; marinheiros formaram os Filhos do Mar e os Filhos de Obá; e bombeiros fundaram os Filhos do Fogo. No início dos anos 50, os Mercadores de Bagdá contavam com uma participação significativa de petroleiros. Entre estes últimos, era notável o projeto de distinguir uma elite de trabalhadores: a indústria da extração e refino do petróleo teve início em 1953, no Recôncavo, produzindo uma classe média negra operária. Uma dissidência, em 1959, faria com que surgissem também os Cavaleiros de Bagdá. 
Alguns ex-associados dos Mercadores e dos Cavaleiros de Bagdá afirmam ainda hoje, com muito orgulho, que "bloco nenhum no Carnaval de Salvador se vestiu com tanta gala". Os motivos das roupas e alegorias correspondiam ao Oriente; não apenas a Índia, como também o mundo árabe, compreendido como o mundo dos califas, sheiks e paxás que causavam admiração, em filmes ingleses e norte-americanos da época, pelos seus palácios, haréns, figurinos, adereços e montarias. Os associados envergavam camisas bem acabadas de cetim, turbantes, colares, pulseiras e adereços de plumas, sapatos de ponta volteada... Alguns poucos montavam cavalos ataviados. Não era considerada importante a sua forma física; as fotografias mostram homens de várias idades que jamais constariam, hoje, numa edição turística... Ao mesmo tempo em que arrancavam efeitos magníficos combinando sopros, percussão e luzes, os blocos de inspiração orientalista não se ocuparam em produzir peças como marchas ou batucadas. Usavam indistintamente sambas tradicionais e marchinhas do rádio que chegavam do Rio de Janeiro. À frente, costumavam vir os arautos tocando clarins, como se fazia também em outros blocos da época e era praticado pelas grandes sociedades. Tanto os Filhos de Gandhi como os Mercadores e Cavaleiros de Bagdá portavam alegorias de camelos e elefantes, presentes com frequência nos filmes sobre o Oriente. A saída deste bloco, como de outros, era carregada de solenidade, recriando cenas do cinema, com destaque para o som dos clarins.

O criador mais lembrado, tanto dos Mercadores como dos Cavaleiros de Bagdá, é Nelson Maleiro, mestre de muitas artes e artesanatos, nascido em Saubara, então um vilarejo de pescadores e marisqueiras no fundo da Baía de Todos os Santos. Ouvi dizer, de vários admiradores dos dois blocos, que "Maleiro parecia um Buda”. Um Buda mestiço, de pernas cruzadas sobre uma almofada, em meio a lanças e escudos enfeitados, insígnias de guerra 
do Islã... que gostava de apreciar Candomblé e cantava o Hino do Senhor do Bonfim antes da saída da sua obra suprema.

Os personagens do Carnaval de Salvador desse período facilmente misturam e recompõem os ícones do maravilhoso, brincando com os tempos e lugares, ou seja, administrando esteticamente a temporalidade e a espacialidade. Da mesma forma, convém não perder de vista a fascinação que sempre exerceram, sobre seus artistas e consumidores, as modas musicais chegadas de outros países. Nos anos 50, quando os ritmos caribenhos começaram a aparecer no cinema, os músicos dos blocos e casas noturnas assistiam atentamente - e várias vezes seguidas - aos filmes para assimilar o repertório. Alguns músicos das casas noturnas Rumba Dance, Montenegro e Tabaris, que costumavam tocar nesses blocos, chegaram a visitar navios para copiar partituras e ouvir - várias vezes, até aprender de cor - alguns artigos mais recentes que a indústria fonográfica norte-americana fazia divulgar pelo mundo inteiro. Os mais apreciados eram aqueles que traziam os ritmos do Caribe: bolero, rumba, merengue, chachachá... Talvez isto explique o aparecimento de blocos como a Embaixada Mexicana, nessa mesma década.

Sobre um velho Ford bigode 1929 - a fobica -, a dupla Dodô e Osmar sai pela primeira vez em 1950, um ano depois do primeiro cortejo do Gandhi; é uma coincidência, sendo bem diversas as condições e motivações para os dois surgimentos. Aquilo que veio a se constituir como trio elétrico e como tal ser conhecido aconteceu, inicialmente, como uma banda elétrica tocando frevos. O cortejo de uma orquestra de Pernambuco sobre um caminhão havia encantado o público meses antes do Carnaval, e a novidade foi incorporada por esses foliões baianos. Todos podiam dançar em torno; não havia associados, era uma folia no sentido mais próprio. A vinheta de partida do cortejo até hoje executada pelos descendentes de Osmar Macedo é a mesma que, nos anos 50 e 
60, ouvia-se em diversos blocos. Se hoje é mais conhecida pela sua referência ao Trio Elétrico Armandinho, Dodô e Osmar, era naquelas décadas associada sobretudo aos blocos de inspiração orientalista.

Sua trajetória é muito rica em transformações e desdobramentos. Em 1951, a fobica foi substituída por uma caminhonete iluminada, com o patrocínio da fábrica de refrigerantes Fratelli Vita. Já era o trio elétrico, com Dodô, Osmar e Aragão. Outros conjuntos de cordas elétricas apareciam e eram também chamados trio elétrico. Em 1957, surgem os trios Tapajós, Marajós e Tabajaras. O modelo da banda sobre um caminhão enfeitado para o Carnaval - o trio - foi delineado por Orlando Campos de Souza, do Tapajós, que passa a atuar em Micaretas (Carnavais extemporâneos) e campanhas políticas a partir de 1963, com o patrocínio da Coca Cola. As aguardentes Jacaré e Saborosa também passavam a patrocinar os trios, que ano a ano cresciam de tamanho e complexificavam-se tecnicamente. É a cara do Carnaval moderno em Salvador. O evento do trio misturava os foliões mais desiguais entre si, na coreografia envolvente de sua música elétrica e eletrizante.

Fred Góes (1982) destaca as modificações que a entrada do trio elétrico no grande circuito da mídia e do mercado fonográfico vai acarretar. A princípio, o trio elétrico tocava frevo, dobrado, marcha e passo doble. Com a introdução de recursos do rock no instrumental e no repertório, e em seguida do canto, ampliaramse consideravelmente as possibilidades de sucesso e a demanda de consumo da banda. O autor também sublinha, já naquele momento, a importância da dinâmica de interpenetração dos diversos estilos musicais e seus respectivos ritmos, como o frevo, o rock e o ijexá, associada à dinâmica de integração do trio ao que seria chamado, a partir do final dos anos 70, de baianidade. 
A década de 60 é o período em que o Carnaval de Salvador conheceu a maior variedade de formas estéticas e modelos organizativos. Aos afoxés, trios elétricos e blocos de inspiração orientalista, acrescentaram-se três novos itens: os blocos de embalo, as escolas de samba e os blocos de índio.

Os blocos de embalo não foram ainda objeto de estudo, quem sabe por não veicularem propostas temáticas convencionalmente classificadas como étnicas. Arrebatavam multidões. Foi junto ao porto que se formou o Vai Levando, o bloco que reuniu um número maior de componentes no seu tempo - cerca de 4 mil -, congregando trabalhadores comuns como prestadores de toda sorte de serviços, biscateiros, empregados nos transportes, vigilantes, etc. Os blocos Secos e Molhados e Deixa a Vida de Quelé ainda hoje são lembrados pelos moradores idosos de seus bairros respectivos, o Tororó e a Federação, como muito originais. Diz-se do Quelé que foi o primeiro bloco a usar saieta e sombrinha; antes de ir às ruas do centro da Cidade Alta, fazia um arrastão, levando consigo os moradores de cada trecho. De repente, os becos e ruas do bairro da Federação e do Garcia transformavam-se em palcos carnavalescos.

As escolas de samba nasceram de uma modesta imitação do modelo carioca. A Juventude do Garcia teve origem na batucada Filhos do Garcia, que em 1956 se apresentava como bloco sem categoria definida e três anos depois já mostra nítida influência das escolas do Rio de Janeiro. Em 1960, já temos os Ritmistas do Samba, da Ladeira da Preguiça, no centro. Em 1961, a Juventude do Garcia já é de fato uma escola de samba, vindo a se oficializar como tal em 1963, quando também surgem os Amigos do Politeama e os Filhos do Tororó, por sua vez descendente do Cordão Carnavalesco Filhos do Tororó, de 1953.

Nos anos seguintes, temos a mais os Filhos da Liberdade e os Diplomatas de Amaralina. Estes nomes mostram como a 
territorialidade permanece experimentada e conceitualizada em termos geográficos. Menos famosas foram os Calouros do Samba, os Acadêmicos do Ritmo e os Independentes da Mangueira. De modo geral, as escolas não tiveram tanto impacto sobre a cena do Carnaval em termos de forma estética. Nem por isso, contudo, se deveriam desprezar alguns aspectos de tão breve aparição. Os bairros que as produziram - sobretudo Garcia e Tororó, próximos do Campo Grande, e o grande complexo da Liberdade, abrangendo Lapinha, Barbalho, Caixa d'Água e IAPI - seriam os celeiros de várias outras entidades, correspondendo a diferentes modelos organizativos que nasceriam sempre pela iniciativa de foliões advindos dos modelos anteriores. Tendo brotado de uma imitação, as escolas de samba se desenvolveram como um espaço que favoreceu a criatividade de inúmeros músicos, coreógrafos, dançarinos e artistas plásticos de seus bairros.

Figurantes da Juventude do Garcia vieram a constituir, em 1966, o Cacique do Garcia, o primeiro bloco de índio de Salvador, influenciado pelo Cacique de Ramos, do Rio de Janeiro. Da mesma forma, associados dos Filhos do Tororó vieram a formar, em 1968, os Apaches do Tororó. Estava deflagrada uma página especialmente vibrante da história do Carnaval de Salvador. Quase todo o movimento dos blocos de índio se deu na área correspondente ao eixo Garcia-Federação-Tororó. Outros blocos de índio, com presença de menor impacto, foram os Guaranis, os Penas Brancas, os Peles Vermelhas, os Xavantes, os Tamoios, os Cheyenes e os Moicanos. Só em 1974 seriam formados os Comanches do Pelourinho. Seguiram-se os Sioux e os Tupis, em 1977, na Federação.

As fantasias dos modernos blocos de índio remontavam nitidamente aos ícones dos adversários dos cowboys e soldados nos filmes norte-americanos. Esparadrapos imitando as pinturas de guerra, calças compridas com espelhos e franjas, cocares, apitos e, no caso dos Apaches, uma machadinha que despertava temor 
em quem sabia como era incômodo o seu golpe à passagem dos índios, alguns deles a cavalo. Seu repertório misturava a batucada comum no meio popular, canções de sucesso no rádio e os hinos próprios, que exaltavam o poder do índio, ao lado de referências frequentes à paz e à confraternização.

Permanece a importância da territorialidade na plasmação dos modelos organizacionais do Carnaval de Salvador. Melhor dizendo, é a própria experiência e concepção de território que se modifica. Com o aumento da frequência e intensidade com que a mídia alcança a população soteropolitana, o que se oportuniza é a reelaboração mais rápida e mais plástica da espacialidade e da temporalidade. Em uma palavra, o mapa-múndi torna-se objeto de manipulação quase cotidiana, sujeito à moda que se instala pela sedução diante dos enunciados da mídia. Esta percepção da relatividade da geografia existencial coincide com a experiência de radical reformulação do traçado urbano de Salvador a partir do final dos anos 6o. A construção das avenidas de vale e viadutos correspondeu à remoção de dezenas de comunidades populares tradicionais, várias delas contíguas aos bairros onde emergiram os blocos de índio, justamente o Garcia, a Federação e o Tororó. Era a contiguidade entre Carnaval e vida urbana que se redimensionava, diante das transformações impactantes da modernização.

No início dos anos 70, vamos encontrar, nos complexos populares de Salvador acima referidos, uma notável proliferação de grupos carnavalescos de diversos perfis. Estava em plena vigência o modelo do bloco de índio e mesmo assim jorrava continuamente o manancial de cultura popular acicatado pelos estímulos cotidianos da mídia. Eram afoxés? Já seriam blocos afro? Grupos de reggae? Ainda eram batucadas? Seriam arrastões? Este esforço de classificação oferece o risco de dispor as diferentes experiências numa categorização estanque que não comportaria o próprio trânsito de elementos entre os modelos. 
Os mesmos jovens e adolescentes frequentavam blocos de embalo e arrastões, afoxés, blocos de índio e alguns outros em que podemos identificar características de vários modelos. É o caso do Gangazumba Dengo Negro, fundado em 1973, em Pau da Lima, bairro distante do centro, e do Viu Não Vá e Puxada Axé, ambos da Federação, bem como do Melô do Banzo, próximo ao Tororó, cuja fundação deve se situar entre 1972 e 1974; alguns depoimentos que recolhi apontam estes blocos como sendo pelo menos tão antigos quanto o Ilê Aiyê.

O que há de comum a quase todos esses grupos que alcançaram legitimidade nos seus próprios ambientes originários é a forte presença do Candomblé como referência identitária, não necessariamente como culto ou vinculação litúrgica direta. É interessante o nome Amigos de Alá. Este grupo nada tinha de islâmico; dava continuidade à vertente tradicional de recorrer aos motivos orientalistas, assimilando com muita desenvoltura as novidades no universo do samba e do reggae, e referia-se eventualmente aos orixás. O bloco Amantes do Reggae tomou este nome como contraponto a um outro bloco, bem menos possante, Amantes do Samba. De Cosme de Farias, veio o bloco Alafin Rei de Oyó, numa alusão a Xangô, homenageado em seus hinos. O Olorum Babá Mi, da Caixa d'Água, é chamado de bloco afro por alguns, de afoxé por outros e simplesmente de levada ou arrastão por outros ainda.

Observa-se nesse período uma configuração múltipla e plástica de modelos carnavalescos nos bairros populares de Salvador. Alguns traços são lembrados como emblemáticos do modelo de afoxé mais tradicional, como o Império de África, liderado desde 1960 pelo pai-de-santo Badu e com sede no bairro de Cosme de Farias $^{3}$. Seu cortejo pelo bairro levava horas com um único hino constando apenas de um único verso, justamente o nome do seja, o Candomblé no Carnaval, no dizer de Nina Rodrigues (1977). 
grupo. Em 1996, último ano em que saiu, era certamente o grupo carnavalesco mais antigo de Salvador. Outros blocos, como o Alafin, também de Cosme de Farias, e o Omolu Ilê, da Barros Reis, tinham um repertório mais eclético. Parece fazer sentido pensar numa correspondência entre tal plasticidade e a própria fragilidade institucional desses grupos: suas sedes mudavam-se com notável facilidade, a depender da facilidade de encontrar uma quadra ou um terreiro, ou seja, um local para os ensaios.

$\mathrm{O}$ adjetivo afro surge com frequência nos depoimentos, às vezes substantivando-se simplesmente como o afro - o clima, o enlevo, a motivação, o motivo e o enredo, tanto como a entidade, o bloco. Compositores, líderes ou simples foliões que transitavam de uma denominação a outra no universo dos blocos negros de então referem-se indefinidamente a qualquer deles dizendo: "era um afro maravilhoso" ou "eu gostava muito daquele afro, não devia ter acabado".

O afro é um vetor estético que alcançou visibilidade em Salvador nesse momento, no qual a Negritude aparece associada à beleza, à força, ao brilho, ao prazer e à novidade. Por um lado, a força do afro repousa sobre o lastro da tradição do Candomblé, sendo também cumulativo com relação a outros vetores, como aquele que se configurou nos blocos de índio. As batucadas ou bandas costumam preceder historicamente os blocos que as adotam ou contratam. Além disso, a plasticidade de seus padrões rítmicos lhes faculta a adaptação aos modelos sucessivos de bloco. Por outro lado, o afro realiza uma descontinuidade na história da música e do Carnaval em Salvador.

O impacto da informação, agora chegando de forma rápida e múltipla, é fundamental neste processo. A própria disponibilização de tecnologias como o gravador portátil constituiu uma novidade considerável. Podia-se facilmente capturar um registro sonoro e manipulá-lo em outro momento e lugar. Circulavam de forma 
palpitante informações sobre a cena política africana, grupos musicais e movimentos políticos negros norte-americanos e a cultura rastafari, que aqui chegava clandestinamente na forma do reggae, do ska e outros ritmos, associados ao consumo da maconha.

Isso correspondeu a uma excitação vigorosa dos padrões estéticos negros tradicionais na Bahia, armando-se uma teia de legitimação recíproca entre esses e as novidades que chegavam pela mídia. A influência do conjunto Jackson Five na onda da discoteca e de inúmeros outros cantores negros, norte-americanos e caribenhos; as notícias sobre a independência dos países africanos, com sabor de vitória e libertação; a formação do Movimento Negro Unificado (MNU), na mesma esteira que originaria também o Partido dos Trabalhadores; a multiplicação dos chamados grupos de jovens negros nas paróquias, associadas a alguns movimentos de pastoral de conjunto - todos estes vetores atuavam na produção de um fecundo caldo de cultura que tomaria forma justamente no que chamo aqui de afro.

Observa-se também um traço de secularização na relação entre as entidades propriamente religiosas e aquelas que se definiam como carnavalescas. A partir dos anos 70, os afoxés foram formados sem ligação institucional estreita com uma casa de Candomblé, como o Oju Obá. Aquele que viria a alcançar maior divulgação foi o Badauê. Em 1978, esse afoxé integrava elementos cênicos novos, como evoluções com leques numa homenagem a Oxum, por exemplo.

Enfim, uma onda estética ao mesmo tempo tradicional e moderna engolfava a cidade, continuando a onda anterior dos blocos de índio; no início, de forma autônoma com relação a qualquer iniciativa das agências da mídia.

Em 1975, o primeiro cortejo do Ilê Aiyê manifestou, diante de um público entre maravilhado e chocado, a força e magnitude do que viria a ser chamado cultura afro. A modernização da cidade, 
com avenidas de vale, shopping center e polo petroquímico, havia oportunizado e fomentado a enunciação de suas origens africanas em linguagem moderna. Suas principais lideranças eram operários do polo. O Ilê também consolidou, na avenida, uma novidade em termos de estilo musical. No seu repertório, observa-se uma forma de samba mais próxima da batucada e outra forma que corresponde à levada de que se tratou acima. Sua iconografia aponta uma África ao mesmo tempo rústica, heroica e brilhante, cheia de chefes militares e religiosos que apareciam pomposamente, donde a abundância de objetos artesanais em corda, cerâmica, sisal, plumagens e peles, que acentuavam o apelo ao primitivo. Ao contrário dos afoxés e pequenos blocos, em que as alegorias percorriam as ruas em caminhonetes, o Ilê trazia um caminhão, como no trio elétrico. As alegorias e adereços afro que se costumavam ver próximos do chão haviam se elevado.

A excitação e reforço do afro com o cortejo polêmico dos primeiros grupos levou à criação de mais quatro blocos nos anos seguintes. As diferentes circunstâncias de seu nascimento, bem como as diferentes vertentes de seu itinerário, ajudam a compreender a nuclearidade do afro. Em 1978, o Malê de Balê surgiu como um bloco de Itapuã, alcançando um sucesso restrito. Em 1979, o Olodum nasceu no Maciel-Pelourinho ao tempo em que o Centro Histórico se encontrava consideravelmente degradado e apenas algumas de suas áreas eram identificadas como ícones turísticos. É provável que aí se encontre pelo menos parte da motivação do Olodum em acentuar em sua apresentação pública a temática do brilho, do esplendor. O Araketu foi gerado em 1980 no subúrbio ferroviário de Periperi. No ano seguinte, o Muzenza, dissidência do Olodum, especializou-se, desde o início, como relicário da cultura reggae, num culto fervoroso à figura de Bob Marley. Este foi o tempo forte de formação dos blocos afro. Vieram ainda o Tenda de Olorum, da Massaranduba, em 1982, e o Afreketê, da 
Liberdade, em 1986, sendo que cada um deles só se faria presentes em dois Carnavais.

Ainda nos anos 70, consolidou-se o conjunto Os Novos Baianos, que plasmou o gênero do trio elétrico vocalizado e eclético. $\mathrm{O}$ trio elétrico dos Novos Baianos apresentou-se pela primeira vez em 1976, tendo à frente Pepeu Gomes, Baby Consuelo e Paulinho Boca de Cantor, quando Moraes Moreira já não integrava o grupo. Era de certa forma uma família sobre o caminhão, porquanto a comunidade zen que se formara no Rio de Janeiro, sob a liderança de Luiz Galvão, permanecera unida no Carnaval. Foram eles que introduziram o teclado e a voz no trio elétrico. Os encontros entre sua geração de músicos e aquela de Dodô e Osmar são até hoje lembrados por muitos foliões dos anos 70 e 80 . A própria interface que se encenava nessas ocasiões em termos de repertório apontava para uma abertura em termos de estilos musicais. Foram veiculadas, então, as primeiras versões trieletrizadas de peças chamadas clássicos, como as Czardas, de Monti, e Brasileirinho, de Valdir Azevedo. A partir de então, estas peças, quando executadas por instrumentistas extraordinários como Pepeu Gomes e Armandinho, passavam a integrar normalmente a cena do Carnaval.

Essa vereda seria percorrida por inúmeros artistas a partir dos últimos anos 70. A referência a ícones do afro acontece continuamente a partir daí. Moraes Moreira, em parceria com Antônio Risério e Fausto Nilo, levou o ritmo ijexá para cima do trio, inaugurando uma configuração singular de ritmos e estilos no Carnaval de Salvador.

A novidade que se seguiria aos blocos afro é comumente chamada axé music, uma interface de repertório musical e coreográfico que se desenvolveu basicamente a partir do encontro entre a tradição do trio elétrico e o evento do afro, que recapitula a tradição da musicalidade negra do Recôncavo em conexão com outras vertentes estéticas da Diáspora. Não se trata propriamente 
de um estilo ou gênero musical, pois não há uma unidade formal interna a esse denominador comum. Não se trata tampouco de um somatório do repertório de determinado tipo de artista ou grupo musical. É uma interface, no sentido de que recursos de composição e interpretação ou aspectos formais de diferentes grupos ou artistas são compatibilizados e/ou identificados entre si, criando-se uma ambiência de que são mais emblemáticos alguns ritmos e coreografias, algumas bandas e intérpretes, sem que se possa observar contornos precisos do estilo, como no caso do tango ou do jazz.

Vemos em cascata a formação de inúmeros blocos de trio, cujo modelo já estava presente nos Internacionais do início dos anos 60. Da mesma forma como o Ilê e os outros blocos afro se identificavam como negros na cena do Carnaval, esses blocos passavam a produzir um padrão próprio do público de classe média, tão entediado dos salões quanto ávido por ganhar a rua. Em 1975, os jovens e adolescentes que frequentavam a Associação Atlética começavam a preferir, ao tradicional bloco Jacu, o novo Traz os Montes, que costumava animar eventos como festas de formatura com o som da Banda Skorpios, interpretando inclusive os sucessos norte-americanos que correspondiam, então, ao repertório mais executado no rádio. Reformulada, essa banda veio a se chamar, na virada dos anos 80, Chiclete com Banana. A maior novidade era a presença da percussão no piso superior do caminhão, junto às cordas. O destaque musical das bandas dos blocos afro era agora entronizado também numa banda de trio...

Entre os blocos de trio formados a partir do final da década de 70, os mais visíveis, além do Papa Léguas, são o Camaleão, de 1978; o Cheiro de Amor e o Eva, de 1980; o Pinel, de 1981; o Beijo, de 1982; e o Mel, de 1983. Numa segunda geração, constariam o Pike, de 1985; o Crocodilo, de 1986; o Frenesi, de 1987; o Patropi, de 1989; e o Pinote, de 1991. Suas sedes passaram a se estabelecer 
na Barra ou adjacências, com caráter nitidamente empresarial. As diretorias, que eram resultado quase sempre de grupos de amigos, colegas de faculdade ou vizinhos, quando não parentes, procuravam incorporar recursos modernos no sentido de administrar o patrimônio e planejar a participação no Carnaval. Nesse conjunto, o Tiete Vips, de 1982, tem associados de classe média mais modesta, mantendo-se ao lado dos grandes blocos sem a primazia do modelo. Na mesma dinâmica, alguns blocos que alcançaram boa visibilidade, como o Joia, são desfeitos; em contrapartida, nascem outros, como Eu Vou, Nú Outro e Bizu, desdobramentos de blocos já consolidados ou suportes para o sucesso de artistas consagrados. As bandas Jheremmias, Jammil e Uma Noites, Pinote e Pimenta n'Ativa encontrariam aí a ocasião para se firmar.

A expressão estética mais própria desse modelo é Luiz Caldas. Tendo iniciado sua carreira no trio elétrico Tapajós, incorporou o merengue, ritmo originário da República Dominicana que chegou à Bahia através da radiofonia de Belém do Pará, sob a denominação genérica de lambada. A partir de 1980, destacou-se com a banda Acordes Verdes, que cativou de imediato o público jovem e adolescente. Luiz Caldas expandiu as possibilidades de criação da música do trio, inaugurando um estilo menos identificado com o frevo elétrico e com o afro, caracterizado justamente pela mixagem ainda mais múltipla, fazendo um sucesso extraordinário já em 1984.

Em 1984, a Banda Furta Cor causou frisson com a execução, no Carnaval, de peças como a Quinta Sinfonia de Beethoven e a Ave Maria de Gounod. A adoção de repertório eclético se ligava à familiaridade com um acervo maior de recursos musicais e tecnológicos. Desponta aí o tecladista e vocal Ademar, que vinha de participar de diversas bandas de trio. O bloco Papa Léguas, de 1978, havia empresarizado esta novidade, que passou a ser então sua marca. 
Outro nome fundamental para compreender esse período é Gerônimo, morador do Centro Histórico. Não tão alinhado com a tradição do frevo elétrico, insiste na junção do ijexá - o afro, falando em termos gerais - com os ritmos de referência caribenha, sobretudo a salsa. Sua apresentação na rua, entretanto, é feita com os recursos do trio elétrico; neste sentido, pode-se afirmar que Gerônimo é um transformador da tradição do trio.

Ao sucesso estrondoso dessa música, veio se somar, no mesmo segundo semestre de 1986, a explosão do Olodum com a temática do Antigo Egito. O bloco realizava ensaios com a quadra lotada às terças e domingos, tendo que transferir os ensaios para o Largo do Pelourinho, pois o pátio do antigo Teatro Miguel Santana não comportava mais tantos admiradores, curiosos e jornalistas. As canções e hinos do Olodum eram ouvidas nas praias, nos sambas dos bairros e nos bares do Pelourinho. Era o ápice a que havia chegado o afro como estilo. Esses eventos eram ocasião de mostras de roupas, broches, cabelos, pormenores como maneiras de amarrar os cadarços, enfim, toda sorte de indumentária exposta e reconhecida como afro. A remissão aos faraós e ao apogeu do império das pirâmides embriagava os músicos e frequentadores.

O Ilê Aiyê havia gravado seu primeiro disco em 1983. O Olodum lançou o seu em 1987, em plena era Faraó, quando já explorava o tema Madagascar. Ainda nesse ano, diversas bandas arregimentadas de forma artesanal gravavam facilmente discos. Um único empresário montou as bandas Raízes do Pelô, Terceiro Mundo e Reflexu's, cuja proposta se definia como entretenimento associado ao afro. Esta demanda excitou sobremaneira pequenos compositores dos bairros populares que frequentavam diariamente o Centro Histórico em busca de canais de sucesso. No mesmo ano, o Araketu também lançou seu primeiro disco. Para os artistas e demais componentes desses blocos e bandas, isto significava uma 
extraordinária legitimação; um reconhecimento que, mesmo parcial, representa como que uma certa oficialidade alcançada.

A expressão axé music - um termo ioruba, outro inglês - torna-se emblemática da vocação e/ou desejo de ocupar um lugar ao sol no grande caleidoscópio da world music, como já acontecia com o regueiro Alpha Blondi, da Costa do Marfim, entre tantos outros. A axé music não tem um enunciador nitidamente demarcado, como no caso do bloco afro e do afoxé. Não procede afirmar, de forma simplificada, que é uma resposta do mundo do trio elétrico e dos soteropolitanos de classe média ao sucesso do afro. Apresenta-se como narrativa identitária difusa e com forte apelo a uma leitura da sociedade soteropolitana como consensual, referindo-se à Bahia como um todo, já desde o início contando com a participação de músicos de várias origens e estilos, inclusive oriundos dos ambientes dos blocos afro.

Foi relevante neste processo a articulação do Olodum com Paul Simon em 1988. A banda participou das gravações do disco Graceland, com o fundo percussivo da faixa Obvious Child, o que valeu ao bloco a primeira viagem à Europa. O Olodum cresceu com a internacionalização. A conexão com Michael Jackson, em 1997, foi ainda mais explosiva. Produziu-se um clipe em duas versões. A que se exibiu no Brasil destaca a arquitetura do Centro Histórico e o ambiente de euforia em torno do Olodum; a outra, de ampla repercussão internacional (cerca de 140 países), mostra também cenas violentas (inclusive de prisões norte-americanas) e fotografias de lideranças negras. Outras viagens - à Europa, ao Japão e aos Estados Unidos - seguiram-se então. A partir daí, observa-se também a conexão do Olodum tanto com estrelas do reggae, organizações não governamentais como a Amnesty International e cineastas como Spike Lee. Destaca-se também a importância do bloco no desenvolvimento do turismo em Salvador, o que configura uma aliança tácita com o governo estadual. No âmbito propria- 
mente musical, a inovação é a incorporação de outros recursos, como instrumentos de sopro e elétricos.

A presença dos rastas foi sempre muito forte no Muzenza, com o objetivo de imprimir certa direção política à sua apresentação em termos de música, coreografia e indumentária. Importa ressaltar que o culto a Bob Marley pode coincidir ou não com a adoção da filosofia rastafari, mesmo porque os ensaios e reuniões se davam em ambiente pouco compatível com os rigores dessa filosofia/ religião. São notas que colocam em cheque a noção convencional de territorialidade. Um rasta que preferiu não dizer seu nome referiu-se assim ao Muzenza: “O território do Muzenza é a cabeça de Marley, velho”. ${ }^{4}$ O Muzenza lançou discos e consagrou certo estilo coreográfico, entre afro e aeróbico, com evoluções diante dos camarotes do Campo Grande e rasgados elogios de personalidades famosas. O que se percebe, no último disco, é que o apelo do reggae se tornou menos imperioso. O bloco afro buscou tornar-se uma banda de axé music e ficou a meio caminho.

Podemos ver no Araketu alguns aspectos semelhantes àqueles encontrados no Olodum. O Ara ou o Ketu, como também passou a ser chamado, empreendeu uma mudança radical de suas formas musicais e coreográficas, aproximando-se do modelo de um bloco de trio, sem manter a referência aos temas explicitamente afro, no que se difere do Olodum.

Enfim, trata-se de um trânsito muito vigoroso, envolvendo afetos os mais diversos. Soteropolitanos (assim como também adventícios) muito desiguais entre si agenciam suas extremidades, suas beiradas, e entram em interação íntima e vibrante. Sem a consideração desta interface de diferentes colorações da epiderme no mundo do Carnaval, estaríamos renunciando a compreender a própria cena do Carnaval como interface em que se encontram os desiguais. Reúno elementos para tomar a dimensão étnica da 
sociabilidade, neste contexto, como a gramática da diferença e da desigualdade. Na mesma esteira de reflexão, considero a dimensão erótica o dialeto principal para enunciar e interpretar o próprio trânsito interétnico, pelas conotações associadas a diferentes formas de sensualidade associadas aos diferentes grupos étnicos.

Ouvi de diversos desses profissionais que, para compor axé music no período coberto por este capítulo, que vai até 1990 , era preciso estar sintonizado com os ícones de baianidade que faziam com que a composição fosse reconhecida como a cara da Bahia. Tratava-se de um repertório que se referia explícita e reiteradamente à Bahia como seu lugar. Este traço é fundamental para a compreensão de como se relacionava a axé music, o meio empresarial e midiático em que se insere e a dinâmica políticoinstitucional baiana.

No encadeamento desses processos históricos, torna-se fundamental compreender o vigor com que se estabeleceu, até o final do século XX, a narrativa da baianidade. Em que consiste sua trama? Ora, na representação da sociedade baiana - tomando-se quase sempre como referência a cidade do Salvador - a partir dos valores da familiaridade, religiosidade e sensualidade. Neste sentido, sua eficácia pode ser melhor compreendida se a dispomos em continuidade com a contribuição de artistas e escritores consagrados como Dorival Caymmi, Jorge Amado, Carybé, Pierre Verger, Caetano Veloso e Gilberto Gil, além de intérpretes que alcançavam muito sucesso já nos anos 60, como Gal Costa e Maria Bethânia.

Uma interpretação facilitadora que se divulgou entre os opositores do líder político Antônio Carlos Magalhães é que o crescimento da axé music pode ser explicado mediante o reforço mútuo entre os governos desta liderança - e de seus comandados - e os artistas da axé music que fizeram sucesso. Ora, por um lado, parece não haver dúvidas acerca da legitimação recíproca entre 
os artistas da axé music e o poderio carlista. Por outro lado, isto é insuficiente para explicar, por exemplo, que o maior crescimento da axé music se deu justamente durante o governo de Valdir Pires e Nilo Coelho, entre 1987 e 1991. Muitos outros fatores compõem a intrincada equação do sucesso, entre os quais não poderia deixar de constar a montagem de condições tecnológicas para a gravação, em Salvador, de um repertório local, a partir da reformulação da gravadora WR em 1984. Não poderia faltar tampouco, nesta equação, o crescimento da indústria do turismo. Eram levas de estrangeiros e brasileiros de outros estados convivendo com pessoas comuns nas ruas, nas praias e no Centro Histórico, compartilhando com os baianos - então mais ufanistas que hoje - o maravilhamento diante de uma cidade que se pensava e se sentia fantástica.

O apogeu desta enunciação da sociedade baiana se dá com a Banda Mel e sobretudo com a Banda Pimenta de Cheiro, esta última em simbiose com o bloco de trio Cheiro de Amor. Sua intérprete Márcia Freire, na virada dos anos 90, alcançaria o máximo em termos de glorificação do ser baiano e realização do nosso narcisismo fantástico ${ }^{5}$. Foi a última intérprete a alcançar grande sucesso no Carnaval de Salvador antes de se configurar a era das estrelas ${ }^{6}$. Ao lado de remissões à história da escravidão e elogios à Negritude, ouvia-se Márcia Freire cantar versos como "Viver a minha vida é o ouro". Nada mais próximo do narcisismo baiano daquele período. Era a própria cidade do Salvador que se transfigurava diante de si própria, dos visitantes e turistas como terra da felicidade, arrematando referências que vinham de muitas décadas atrás.

5 Uma apresentação mais cuidadosa destas dinâmicas não poderia dispensar a consideração do repertório dos diferentes setores do Carnaval de Salvador, o que seria inviável nos limites de extensão deste capítulo.

6 Marilda Santanna (2009) analisa minuciosamente como a formação e consolidação das carreiras de Margareth Menezes, Daniela Mercury e Ivete Sangalo já corresponde a um outro modelo de relação com o público e o empresariado, inserido no circuito pop. 
A conexão da narrativa da baianidade com a vida social e política que se experimentava na Bahia é que tensionava seu enunciado e lhe conferia sentido diante dos baianos. Seja para aqueles que se deleita(va)m com esse texto, seja para aqueles outros que o detesta(va)m, a baianidade fazia sentido como válida ou inválida enquanto referida à vida dos baianos. Esta narrativa procurava justamente organizar essa teia na forma de um consenso sedutor. Para os grandes públicos baianos, as referências do pagode baiano e da axé music são locais e, ao mesmo tempo, articuladas ao nacional e ao internacional; o local é reconfigurado como nacional e internacional, sem deixar de ser local.

No contexto da axé music, como da narrativa da baianidade, não há Bahia sem esta conexão. A própria referência de Bahia, seja para os baianos, seja para os outros brasileiros, é articulada com a referência à relação da Bahia com o mundo, por razões que os historiadores costumam revisitar. A cidade do Salvador foi, desde o início, fortemente marcada pela internacionalidade, o que não nos dispensa de considerar que a internacionalização não acontece da mesma forma em nichos geográficos diferentes, nem da mesma forma em todas as épocas. A configuração imagética dos diversos modelos carnavalescos tratados acima já aponta para esta intimidade com o mapa-múndi.

\section{UM CORTEJO DE CORTEJOS}

Cabe colocar, então, a pergunta pelo que poderia ser a percepção ou a experiência da territorialidade relacionada à fantasia na história do Carnaval de Salvador. A partir das leituras dos autores comentados no início deste texto, insisto em que Carnaval é fantasia. Não apenas fantasia; contudo, em se retirando esta marca, perde-se do Carnaval aquilo que lhe é mais próprio. A referência a 
territórios próximos ou distantes configura, alegoriza, esteticiza a reflexão sobre este ou aquele tema. A linguagem do Carnaval não se identifica com aquela da academia, do jornalismo ou da crônica, pois é linguagem fantástica. A desconsideração desta especificidade exime o observador de captar o Carnaval propriamente dito como objeto de sua apreciação.

Procurei mostrar, rapidamente, a força das imagens de outros mundos na formação de grupos como os Filhos de Gandhi e os Mercadores de Bagdá. Mesmo no caso da Embaixada Africana e dos Pândegos da África, se havia ainda africanos idosos entre os associados, a quantidade de informações veiculadas pelo seu cortejo aponta para uma África fantástica e, ao mesmo tempo, uma África que chegava pelas informações dos viajantes e dos jornais. É o território ancestral próximo que se completa com uma territorialidade alegórica, numa maravilhosa estetização carnavalesca.

Cabe tomar cuidado, contudo, quando se fala de território no Carnaval. Não se trata necessariamente de um país, o campo geográfico correspondente a uma etnia, uma cidade ou pátria distante; não é necessário que corresponda àquilo que tem o mesmo nome na cartografia, na geografia e na historiografia. No modelo dos afoxés formados antes dos Filhos de Gandhi, era o terreiro que saía à rua, como bem reconheceram os etnólogos da primeira metade do século XX. No modelo da mudança, que vicejou até recentemente, o território era o próprio bairro levado sobre as carroças e despejado no centro da cidade.

Os Filhos do Fogo levavam alegorias que identificavam a corporação dos bombeiros e envergavam fantasias de cetim vermelho. No caso dos Filhos de Gandhi, o porto não era visível como alegoria, mas quem via passar o afoxé sabia que eram doqueiros muitos de seus associados. Já os Filhos do Porto levavam às mãos ou à cabeça ícones emblemáticos da profissão, como pequenas alegorias de guindastes, embarcações, armazéns, etc. Na linguagem 
do Carnaval, a profissão era espacializada na referência ao porto, contínuo à zona comercial modesta, às casas de prostituição, às casas noturnas de shows e aos castelos. Os Filhos do Mar não se referiam diretamente ao porto, mas precisamente à navegação, daí as alegorias de âncoras, velas, salva-vidas, sinaleiras de mar e navios. O mar é como a beirada do mundo, numa cidade que tem sua história quase sempre ligada ao comércio com terras distantes.

A partir de um contato mais frequente com outro tipo de cinema, aparecem modelos como o bloco de índio, que combina a localização dos associados em um bairro com a referência imagética alegórica a um tipo, o índio adversário dos cowboys e soldados yankees; dois vetores complementares de territorialização, portanto. Para quem morava nos bairros que sediavam os blocos de índio, era tão importante ser Cacique como ser do Garcia; tão importante ser Apache como ser do Tororó.

Com a fundação dos blocos afro, a referência a outros mundos torna-se mais complexa e diversificada. Era costume o bloco adotar um país africano a cada Carnaval e divulgar hinos sobre alguns motivos desse país colhidos nas apostilas preparadas pela Diretoria. Isto começou a mudar quando, em 1986, o Olodum escolheu Cuba como tema. Foi a partir dessa novidade que a noção de Diáspora Negra começou a excitar o imaginário dos compositores e, de modo geral, dos frequentadores das quadras do bloco. O impacto maior viria mesmo em 1987, quando o Olodum anunciou que o Egito, com todo o esplendor de seus faraós e pirâmides, era negro. O impacto se manteve em 1988, quando o bloco anunciou como motivo a ilha de Madagascar, país africano de iconografia muito singular. Os aficcionados se deleitavam com as reportagens trazendo fotografias de animais e plantas exóticas, ontem estranhas, como se não apenas outro país, mas outra época da Evolução se fizesse presente na quadra. Pouco depois, os dirigentes dos blocos afro se deram conta de que a simples remissão à 
meia centena de países africanos já se esgotara, sendo necessário apelar para temas carnavalescos independentemente de contornos geopolíticos convencionais. Em 1989, o mesmo Olodum escolheu a Índia como tema.

Dizia-se do Ilê, entre outros predicados, que era um bloco do bairro da Liberdade. Ora, o maior bairro negro da Salvador dos anos 70 já era referido à importância da Negritude, por sua vez compreendida como Diáspora7, na configuração moderna da cidade. O Ilê era também associado ao que se passava nos Estados Unidos, no Caribe e na África como desempenho estético e político de grupos negros. Do Olodum, dizia-se que era o bloco do Maciel-Pelourinho. Ora, este nunca foi um bairro pobre a mais; era o Centro Histórico visitado por turistas de todo o mundo e cartão postal da cidade e do país. Na própria referência ao lugar originário do Olodum, já está contida sua conexão com o mundo, forte marca de seu perfil. O Muzenza era uma Jamaica itinerante. Como os regueiros mais identificados com o Rastafarianismo, não se identificava com um bairro; seu mundo era aquele de Marley, pontuando entre a Babilônia e a Jerusalém das letras do reggae. A inauguração do Candeal Gueto Square, casa de shows da Timbalada no próprio bairro onde nascera Carlinhos Brown, sinalizaria, nos anos 90, a articulação entre as duas dimensões de territorialidade fortemente cultivadas sob a égide do fundador: a pretensão de ser world music e a localização no bairro popular tradicional do Candeal. O próprio Brown afirmava que sua criação não cabia mais no modelo do bloco afro; era afropop. Ou seja, já inserido em outra dinâmica do sucesso, planejada e praticada em larga escala.

7 Este termo não é corrente em Salvador. Refiro-me à percepção da presença negra na Bahia como vertente de um movimento muito mais amplo, a que Gilroy (1996) chama êxodo atlântico. 
O que se deu a partir do boom de Faraó foi uma notável aceleração do ritmo com que a cidade - aqui representada pelos seus artistas - apropriava-se do mapa-múndi, com uma lógica muito diferente daquela da geografia convencional. Centenas de artistas passaram a compor canções misturando e/ou associando magicamente países, cidades, personagens, eventos, datas, etc. Poderíamos dizer que sua grande mensagem é o desejo e o poder de manipular o mapa, de revertê-lo a nosso favor, de fazer com que atenda a nossos desejos? A manipulação das referências de espaço geográfico e sua recomposição na forma de um quadro em que faça sentido a existência como algo desejável e belo encontra assim, na cultura de Carnaval, a ocasião mais propícia.

O destino da maioria dos habitantes de Salvador está marcado por um deslocamento forçado e terrível, a captura e o tráfico de cativos africanos. A partir da elaboração e enunciação deste traço pela mídia e pelos diversos tipos de movimentos negros que lograram se estabelecer como matrizes discursivas, os afrodescendentes mais jovens foram chamados a se colocar diante deste deslocamento. Convido o leitor a tomar a Diáspora não apenas como uma migração localizada cronologicamente, que seria o processo histórico fundante. Diáspora, aqui, é dito também como a condição existencial de grande parte da população, que experimenta desfavoravelmente sua inserção nesta sociedade em virtude da forma como seus ascendentes foram aí integrados. Em contrapartida, Diáspora é ainda o conjunto das estratégias que, nestes séculos, os afrodescendentes vêm empreendendo no sentido de construir continuamente sua existência com sentido.

É oportuno, neste momento, colocar o problema das diversas formulações identitárias, às vezes antinômicas entre si, no período comentado. Os textos identitários colocados no âmbito do Carnaval podem ser entendidos como enunciados da dramática busca de identificação que envolve diversos setores sociais da mesma cida- 
de. Estes setores, por sua vez, remetiam-se a dinâmicas estendidas globalmente. Neste complexo sistema de textos identitários, a referência ao lugar e ao mundo ocupava um lugar especial, e isto se fazia ao mesmo tempo em que se estabelecia um trânsito contínuo de épocas e momentos. Todos precisamos ser de algum lugar e, para quem é des-locado, ser de algum lugar numa sociedade nova e desigual demanda inclusive vir de algum lugar.

Nesta perspectiva, a mistura de referências geográficas, ritmos e temáticas na música de Carnaval de Salvador pode ser lida como expressão de uma autopercepção da cidade que se colocava como écran da multiplicidade flagrante do mundo e procurava se situar nesta multiplicidade, assumindo-a na elaboração de seu(s) texto(s) identificador(es). Na dinâmica de enunciação destas narrativas identitárias, ora prevaleciam as arestas, ora as curvas. Podia ser que um modelo já estabelecesse as curvas de seu modelo exitoso quando um outro modelo estivesse ensaiando, vigorosamente, as arestas de sua novidade. A tensão do Carnaval se fazia pela coreografia dos dois vetores.

Quem dizia "o trio do Olodum" percebia que o bloco afro soubera captar, do modelo do bloco de trio, um recurso, um poder. Da mesma forma, quando se vibrava com uma canção falando de ícones do afro na voz de Ricardo Chaves, reconhecia-se que o cantor branco, de classe média, soubera captar o charme do afro; dito de outra forma, capturar o axé do bloco afro. O senso comum divisava aí o hipercortejo na forma de um cortejo no evento de outro cortejo; o cortejo de um modelo de Carnaval no cortejo de um outro modelo de Carnaval. Como a vinheta de metais executada na partida do cortejo das grandes sociedades e dos blocos de inspiração orientalistas, que logo foi assimilada ao trio elétrico. A cada experiência de Carnaval, quem passava em cortejo era o próprio fluxo dos cortejos, na sua diversidade de modelos, épocas e temáticas. E era precisamente esta mirada que, em se radicali- 
zando, levava ao metacortejo, ou seja, o cortejo do próprio cortejo. O que estava passando cedia a primazia a que estivesse passando. O predicado se faz sujeito, porquanto englobante da dinâmica espetacular do Carnaval. Quem passava, antes de ser esta ou aquela formulação fantástica, era a própria fantasia.

No contexto do Carnaval, a fantasia tinha o poder de transformar os dias de folia em algo radicalmente distinto dos outros dias do ano. Mesmo que o folião não soubesse bem o que era um barco viking, era em êxtase que o levava como alegoria de um mundo diferente, como mostram tantas fotografias dos anos $50 \mathrm{e}$ 6o. Fazer-se fotografar fantasiado, prática muito comum nos dias de Carnaval, era como perenizar, para si e para os outros, o poder de reverter a ordem normal do tempo.

Aos efeitos de uma caracterização contrastiva, permita-me o leitor uma breve referência ao Carnaval soteropolitano do início do século XXI, quando esta dinâmica fantástica entraria em refluxo. O êxtase de se perder na multidão, bem como a alegria radiante de viver um personagem, cederia espaço diante da excitação provocada pela passagem das estrelas, tão regulada pelas empresas que promovem a festa - seja a excitação dos mais pobres, mais escuros e menos letrados, no chão e nos cantos das ruas, seja a excitação dos mais ricos, mais claros e mais esclarecidos, no centro das ruas e nos camarotes, para recapitular a disposição dos setores sociais na pequena cidade francesa de 1580 , estudada por Ladurie.

O Carnaval de Salvador continuaria sendo espetacular, mas não mais fantástico, pois a Bahia deixaria de ser cultivada como uma terra mágica, encruzilhada de mundos e tempos. A intensidade com que os fãs clubes fruem a passagem de Ivete Sangalo e Daniela Mercury, do Olodum e do Ilê Aiyê, do Asa de Águia e do Chiclete com Banana, do Parangolé e do Psirico, bem como de outros artistas e grupos, não permite duvidar da vitalidade da festa enquanto cultura de entretenimento e paixão e realização de 
expectativas ansiosamente acalentadas. $\mathrm{O}$ mesmo se pode dizer das multidões que praticam a música e a coreografia, renovadas a cada ano, das bandas de pagode. Entretanto, não seria mais o momento por excelência de uma segunda vida do povo, na leitura de Bakhtin.

A narrativa da baianidade, última formulação de referências fantásticas no Carnaval de Salvador, conheceu seu desgaste e diluição. A cidade que tirou de sua relação com o mundo o motor de sua vitalidade cultural agora parece ter perdido o passo desta relação. Ao contrário do que pensava Baroja, talvez o Carnaval não tenha terminado de todo. É possível que o futuro venha colocar, no palco da história da festa nesta cidade, novas fantasias de lugar. E assim, pode ser que a Baía volte a ser vivida como uma rota. Quem sabe será possível afirmar, de outra forma, que o Oriente é aqui, como fez Nelson Maleiro no seu tempo... Que bagagem estaria presente nas praias da Baía, lugar de trânsito intenso de tantos mundos?

\section{REFERENCIAS}

BAKHTIN, Mikhail. A cultura popular na Idade Média e no Renascimento: o contexto de François Rabelais. Tradução por Yara Frateschi. São Paulo: Hucitec; Brasília: EDUNB, 1993.

BAROJA, Julio Caro. El carnaval, Madrid: Taurus, 1965. . Disposiciones antropológicas. Madrid: Istmo, 1985. BURKE, Peter. Cultura popular na Idade Moderna. Tradução por Denise Bottmann. São Paulo: Companhia das Letras, 1989.

CARNEIRO, Edison. Religiões negras: notas de etnografia religiosa. 3. ed. Rio de Janeiro: Civilização Brasileira, 1991.

DAVIS, Natalie. Culturas do povo. Tradução por Mariza Correa. Rio de Janeiro: Paz e Terra, 1990. 
FÉLIX, Anísio. Filhos de Gandhi: a história de um Afoxé. Salvador:

Gráfica Central, 1987.

FÉLIX, Anísio; NERY, Moacir. Bahia, Carnaval. Salvador: [s.n.], 1994. 293p.

FERREIRA, Felipe. Inventando carnavais: o surgimento do carnaval carioca no século XIX e outras questões carnavalescas. Rio de Janeiro: Editora UFRJ, 2005.

GILROY, Paul. The black atlantic: modernity and double consciousness. Cambridge: Harvard University Press, 1996.

GÓES, Fred de. O país do carnaval elétrico. Salvador: Corrupio, 1982. (Coleção Baianada, 4).

LADURIE, Emmanuel Le Roy. Le carnaval de romans: de la chandeleur au Mercredi des Cendres - 1579-1580. Paris: Gallimard, 1979.

RODRIGUES, Nina. Os africanos no Brasil. 5. ed. Revisão e Prefácio de Homero Pires. São Paulo: Nacional, 1977.

SANTANNA, Marilda. As donas do canto: o sucesso das estrelasintérpretes no carnaval de Salvador. Salvador: Edufba, 2009.

VIEIRA FILHO, Raphael Rodrigues. A africanização do carnaval de Salvador, BA: a recriação do espaço Carnavalesco (1876-1930). 1995. 228 f. Dissertação (Mestrado em História) - Faculdade de Filosofia e Ciências Humanas, Pontifícia Universidade Católica de São Paulo, São Paulo. 


\section{Capoeira Angola}

africana, baiana, internacional

CHRISTINE NICOLE ZONZON 


\section{DO ÍCONE DA IDENTIDADE BRASILEIRA AO RESGATE DA AFRICANIDADE}

A imagem da capoeira, hoje associada à representação de uma Bahia africana, étnica e tradicional, recebeu ao longo da história múltiplas interpretações, seja nas vozes dos próprios protagonistas, praticantes dessa arte, seja naquelas dos comentadores que se interessaram por essa temática desde os primórdios do século XX.

Os debates e reflexões sobre o que seria a verdadeira natureza e origem da capoeira passaram a intensificar-se na época da legitimação da prática, no final dos anos de 1930, chegando a levantar duras polêmicas entre os diversos comentadores. Nas matérias publicadas em jornais, nos escritos dos mestres, nos trabalhos acadêmicos que se dedicaram ao estudo da capoeira, vemos reiterado o esforço em captar a singularidade dessa manifestação, cuja natureza complexa dificulta que seja classificada através de expressões tais como jogo, dança, esporte, luta tradicional ou arte marcial. 
Os questionamentos relativos a seu local de surgimento despertaram debates mais acirrados ainda. Foi criada no Brasil pelos escravos? Nasceu na África? Teria recebido influências de rituais indígenas e/ou de elementos oriundos de elementos culturais europeus ${ }^{1}$ ?

As argumentações a favor de uma ou outra dessas versões recorriam a fontes múltiplas como pesquisas historiográficas ou etnográficas e estudos etimológicos da palavra capoeira ${ }^{2}$, além da investigação da tradição oral. Conferia-se uma grande relevância à resposta a essas interrogações, pois subjacente à questão da origem da capoeira, estavam em jogo o valor a ser atribuído a essa manifestação, bem como a legitimidade dos grupos que poderiam, com direito, reivindicar-se como representantes da sua tradição.

No processo de legitimação da capoeira, a temática da identidade nacional passou a orientar argumentações que visavam a dar à antiga capoeiragem um novo status. Após terem perseguido, condenado e deportado seus praticantes - pois os capoeiras foram considerados como vadios, vagabundos e desordeiros durante mais de um século ${ }^{3}$ - a capoeira tornou-se então um dos ícones da identidade brasileira. A capoeira é nossa. O americano tem o boxe. Japonês tem o judô. E nós? intitulava um jornal baiano de $1946^{4}$, numa época em que os capoeiristas enfrentavam no ringue lutadores de outras artes marciais como jiu-jítsu, judô, luta livre ou boxe. Essa mesma representação enquanto "luta brasileira", competindo no mercado das artes marciais com outras modali-

\footnotetext{
1 Notadamente do fadista português com o uso da navalha. (SOARES, 1994)

2 Mais particularmente, no estudo de Waldeloir Rego, que dedica um capítulo ao estudo etimológico da palavra capoeira. Associa ao termo tupi caa-puera, que designa um mato ralo, onde possivelmente os escravos teriam exercitado a luta. (REGO, 1968)

3 A criminalização da capoeira entra no código penal em 1890, mas os capoeiristas já sofriam repressão por crime de vadiagem desde 1821. Sobre a história da capoeira no século XIX, ver o trabalho de SOARES (1994). Jornal A Tarde, 7 de fevereiro de 1946.
} 
dades orientais ou europeias, fundamentou a criação da capoeira regional, uma iniciativa muito bem sucedida de Mestre Bimba no sentido de dotar essa prática tida como "coisa de preto", ou seja, marginalizada e estigmatizada, de um sistema de ensino sistemático visando a tornar a luta mais eficiente. (ABREU, 1999)

Por sua vez, a (re)criação da capoeira angola - nos anos 40 constituiu-se em resposta e numa dinâmica de concorrência com relação ao sucesso obtido pela capoeira regional de Bimba, que vinha ganhando visibilidade e reconhecimento graças à confiança $\mathrm{e}$ ao apoio das classes média e alta. (ABIB, 2005; REIS, 2000; ZONZON, 2001) Tratava-se de outra estratégia no sentido de construir uma nova imagem da capoeira que pudesse ser mais bem aceita socialmente. Nessa segunda sistematização, foram destacados os elementos religiosos e lúdicos da capoeira, a temática da identidade nacional dando lugar a um resgate da herança africana. Enquanto, segundo Mestre Bimba, a capoeira tinha nascido dos negros escravos nas senzalas do Recôncavo, a capoeira angola reivindicava sua origem na mãe África, afirmando-se como continuum de uma tradição com forte identidade étnica.

Elaborada por mestres baianos, entre os quais se destaca a figura de Mestre Pastinha como maior liderança, a capoeira angola recebeu a adesão de uma parcela importante da intelectualidade baiana, que a escolheu como capoeira "pura", valorizada enquanto autêntica herança cultural africana ${ }^{5}$. Em paralelo, estudos antropológicos desenvolvidos nos anos 60 revelavam a existência de um rito de passagem consistindo numa luta entre dois rapazes, observado em Angola e chamado de dança da zebra ou N'golo. Semelhanças notáveis entre os movimentos desempenhados em tal luta ritual e aqueles que caracterizam a capoeira brasileira, ressal-

$5 \quad$ Entre os artistas que desempenharam um papel significativo para o reconhecimento da capoeira angola, destacam-se Jorge Amado, Carybé e Pierre Verger, sendo os três grandes amigos e admiradores de Mestre Pastinha. 
tadas pelo autor do estudo, forneceram o insumo para pesquisas ulteriores argumentando a favor da origem banto da capoeira ${ }^{6}$. A descoberta dessa provável matriz da capoeira foi decisiva para os futuros rumos da capoeira angola: a dança do N'golo como possível origem da capoeira é retomada em praticamente todos os trabalhos acadêmicos enfocando este tema dos últimos 30 anos. Mais tarde, a imagem da zebra seria escolhida como emblema de vários grupos que a estampam em suas fardas.

Contudo, a versão africana da capoeira não exercia o mesmo poder de sedução do que suas aplicações no universo esportivo, e, na disputa entre capoeira regional e capoeira angola, a primeira levou uma inegável vantagem. Praticamente ameaçada de extinção, nos anos 60/707 , a modalidade angola só iria encontrar um segundo fôlego junto ao crescimento da "consciência negra" e dos movimentos de reivindicação identitária conhecidos como "movimentos negros", no cenário dos anos 80/90.

Essa trajetória de revitalização da capoeira angola nos interessa particularmente por definir-se a partir de conceitos como resgate, reafricanização e ritualização. Assim, se, na sua interpretação esportiva associada à identidade brasileira, a capoeira de Bimba se mostrava à altura dos valores da modernidade - pois, como os demais esportes, repousava sobre um sistema de ensino e disciplina sistemático visando à eficiência -, na reconstrução da capoeira angola, são os elementos que traduzem um passado tradicional, ancestral, pré-moderno que norteiam os discursos e os fazeres.

6 A primeira referência ao trabalho deste antropólogo é encontrada em Câmara Cascudo (1967, p. 184). Diz ele: "Albano de Neves e Sousa, de Luanda, poeta, pintor, etnógrafo, encarregou-se de elucidar o lado de lá; as fontes da capoeira".

7 A morte da capoeira angola é anunciada pelo etnólogo Waldeloir Rego em 1968, na sua obra clássica. O autor atribui a morte da prática à descaracterização da "pureza" do jogo sob os efeitos das políticas de turismo empreendidas em Salvador. (REGO, 1968) 
As raízes africanas da manifestação são enfatizadas através de processos que afetam, na prática, os modos de aprendizagem e de execução. A realização da roda de capoeira é um elemento que acaba se tornando fundamental na ressignificação do jogo: passa a ser encenada conforme um roteiro ao mesmo tempo definido e flexível em que as formas expressivas, corporal e musical, os papéis dos protagonistas, as configurações espaciais e temporais da performance são formalizados e ritualizados.

No âmbito discursivo, isto é, dos ensinamentos transmitidos através da tradição oral, de mestre para aluno, e das declarações das figuras de liderança na ocasião dos encontros, eventos e workshops de capoeira que se multiplicam a partir dos anos 90, a reafricanização da capoeira angola passa por releituras da história da antiga capoeiragem que tendem a omitir alguns episódios mais ambíguos do seu passado ${ }^{8}$.

Esquece-se do envolvimento dos capoeiristas na marginalidade urbana e na capangagem política do fim do século XIX, ao passo que são ressaltadas as analogias entre capoeira e quilombos e privilegiadas as suas semelhanças com o candomblé, reforçando assim as dimensões "espirituais" do ritual. A afirmação de Mestre Pastinha ("capoeira tem fundamento"), que vincula implicitamente a luta com o universo da religiosidade afro-brasileira, torna-se o mote dos angoleiros e o marco distintivo em relação à capoeira regional.

A associação da capoeira com um passado mítico e a identificação com uma África imaginada tem orientado o processo de reestruturação e de expansão da capoeira angola nas últimas décadas do século XX. A multiplicação dos grupos na Bahia, no Brasil e no mundo, ao mesmo tempo em que põe em evidência o sucesso dessa interpretação, traz à reflexão um segundo aspecto

8 O fenômeno de seleção de memórias em função dos critérios do presente é tratado por Hallbwachs (1990). 
ligado à africanização da capoeira. Há uma mudança significativa na composição desses grupos que passam a atrair membros de origem social, geográfica e étnica extremamente diversificada, e, intimamente vinculada a essa heterogeneização, uma ampla adesão de mulheres à prática.

A ressignificação da capoeira na sua modalidade "angola", também chamada de capoeira raízes e/ou tradicional, ocorre, portanto, através de um duplo movimento: por um lado, a prática se define como autêntica manifestação da cultura negra, ancorada numa tradição ancestral africana banto; por outro, abre-se a um público que rompe com o perfil tradicional do capoeirista - o de um homem, negro, oriundo das camadas populares da Bahia -, além de expandir-se por novos territórios dentro e fora do Brasil.

Dito de outra forma, pode-se falar numa miscigenação dos grupos em termos de origem étnica ou social e de gênero, concomitante a um reforço da identidade africana associada aos atributos de autenticidade e de pureza. Ou ainda, quanto mais a capoeira se configura como vínculo ou resgate de valores pré-modernos (como religiosidade, espiritualidade, ancestralidade, ritualidade, comunidade) que implicam modos de se relacionar com o tempo, o espaço e o outro, remetendo a tradições africanas, mais atrai e acolhe um público diversificado cuja adesão à prática só se tornou possível em função de processos próprios à contemporaneidade, entre os quais o desenvolvimento das tecnologias das comunicações aparece como o mais evidente.

Essa capoeira africana e internacional, tradicional e moderna encontra na Bahia seu território, seu centro e seu destino. De fato, se a sua origem imaginada remete a terras e tempos perdidos do continente africano, a cidade de Salvador e, em proporções menores, a região do Recôncavo têm se consolidado como principal referência da capoeira no Brasil e no exterior, literalmente - nos termos dos grandes mestres da Arte - uma "fonte" onde todos, 
algum dia, hão de beber ${ }^{9}$. Assim, a imagem étnica da capoeira, particularmente enfatizada na sua vertente angola, passa a compor uma certa narrativa da Bahia e a integrar as representações de uma cultura baiana tradicional em que a música e a religiosidade se constituem como atrativos para a indústria turística.

O objetivo deste capítulo é ponderar em que medida o contexto contemporâneo que propicia uma abertura do universo até então bastante estreito e uniforme da capoeira para o mundo moderno e cosmopolita orienta algumas releituras que enfatizam o seu caráter tradicional e étnico. Procura-se encontrar na singularidade da prática os elementos que permitem acolher essa alteridade étnica e cultural, o que nos leva a focar mais detalhadamente os jogos de interação com um "outro" que caracterizam o savoir faire do angoleiro. Atenta-se particularmente aos critérios de excelência que norteiam a transmissão, destacando-se, entre os princípios práticos da capoeira angola, o desenvolvimento de habilidades e competências para elaborar um jogo, ou seja, uma comunicação corporal, com qualquer tipo de adversário. A hipótese sobre a qual repousa a nossa trajetória analítica é que os agentes responsáveis pela perpetuação dessa prática recorrem ao repertório tradicional para estabelecer uma dinâmica de relação com o "diferente" que constrói ou consolida a identidade própria em termos de pureza e autenticidade.

Tal perspectiva implica apreender os modos práticos de agir desempenhados no jogo de capoeira angola em sua dimensão inseparavelmente física/corporal e ética, entendendo a movimentação corporal como uma linguagem, expressando e gerando valores, julgamentos, posições e relações de poder além de, é claro, conflitos. Consequentemente, desenvolveremos uma apresentação das

9 Outra imagem geralmente usada pelos capoeiristas para falar de Salvador é a metáfora do "berço". Assim, a Bahia seria simultaneamente o berço do Brasil e o berço da capoeira. 
modalidades de aprendizagem/transmissão e de execução do jogo da capoeira angola no intuito de trazer à tona as permanências e as mudanças decorrentes da heterogeneização dos praticantes. Tratar-se-á de examinar os vínculos entre as alterações que afetam o campo (idealmente, o conjunto dos praticantes que compõem o universo da capoeira angola), as práticas corporais e rituais e as narrativas identitárias.

Num segundo momento, pergunta-se de que maneira as estratégias que desempenham um papel no processo de um enraizamento ainda mais profundo e sólido na tradição dita ancestral da capoeira angola estariam atuando num universo mais amplo. A questão que propomos levantar é de uma possível analogia entre as dinâmicas de identidade étnica que organizam as narrativas da capoeira e as atuais versões de uma baianidade negra e tradicional, com fortes apelos a conotações místico-religiosas. Trata-se aqui de aprofundar os elementos subjacentes a um estereótipo que faz do capoeirista um emblema da dita "baianidade", ou seja, indagar o que o jogo da capoeira pode expressar sobre a identidade baiana ou, mais especificamente ainda, sobre os modos de relação entre uma baianidade que se define pela sua especificidade étnica e se espelha na sua origem africana e o mundo de fora que se faz cada vez mais presente no contexto contemporâneo da Bahia.

\section{ABERTURA E EXPANSÃO DO UNIVERSO DA CAPOEIRA ANGOLA}

Como foi brevemente evocado acima, o universo da capoeira abriu-se para camadas sociais não tradicionais e expandiu-se em novos horizontes geográficos no decorrer dos processos de legitimação e de ressignificação da prática que se estendem praticamente do final dos anos de 1930 até os dias de hoje. É preciso 
lembrar que até o início desse período, era muito difícil - se não impossível ${ }^{10}$ - encontrar, entre os capoeiristas, pessoas brancas oriundas da classe média.

Esquematicamente, poder-se-ia dizer que a esportização propiciou a adesão da burguesia branca à capoeira e com a folclorização, a partir dos anos 50/60, iniciou-se a internacionalização da manifestação quando capoeiristas baianos passaram a viajar para o exterior apresentando seus espetáculos. Alguns dentre eles, inclusive, resolveram ficar por lá, abrindo as primeiras academias de capoeira na Europa e nos Estados Unidos. Esse processo de miscigenação do público da capoeira intensifica-se no seio dos grupos de capoeira angola que surgem a partir dos anos 80, em Salvador, e nas décadas seguintes, nas grandes cidades de outras regiões do país, assim como em inúmeras cidades dos cinco continentes.

A internacionalização da capoeira tem como efeito engendrar um movimento de vai e vem de mestres e alunos viajando ao redor do mundo: os mestres se deslocam para regiões e países onde pretendem implantar ou já implantaram antenas de seus grupos, ao passo que os alunos que se iniciam à capoeira nesses locais vêm passar temporadas na Bahia para aperfeiçoar-se na prática da capoeira e conhecer as verdadeiras fontes e as formas autênticas da arte. Eventos, encontros, workshops internacionais são organizados pelos grupos que chegam a reunir, nessas ocasiões, centenas de capoeiristas brasileiros e estrangeiros, todos eles motivados pela busca de um saber que só se encontraria no contato com os grandes mestres da Bahia.

Observa-se também uma diversificação dos praticantes da capoeira angola no que diz respeito à faixa etária e ao gênero. $\mathrm{O}$ ensino da capoeira passa a ser percebido como um instrumento de

10 Em depoimento, alguns dos ex-alunos de Mestre Bimba relataram que com a criação da sua academia de capoeira regional surgiu, enfim, a possibilidade de eles se iniciarem à capoeira apesar de serem jovens universitários brancos. 
educação e cidadania e é adotado em projetos sociais que atendem crianças e adolescentes.

Junto a essa população infantil de ambos os sexos, o universo da capoeira vai acolher um número cada vez maior de mulheres. Entre os diversos fatores que podem ajudar a explicar tal feminilização da capoeira, vale ressaltar que esse fenômeno está estreitamente vinculado à diversificação dos praticantes em termos de origem geográfica, pois a proporção de mulheres mais significativa é encontrada entre os capoeiristas estrangeiros e entre aqueles que vêm de outras regiões do Brasil ${ }^{11}$. Percebe-se, portanto, que o ingresso de um público não nativo - não baiano - potencializa uma heterogeneização mais ampla que resulta, por sua vez, numa diversificação ainda maior dos componentes dos grupos em termos de gênero e nível sociocultural.

Estudantes, professores, artistas, funcionários públicos, profissionais liberais, jovens em situação de risco, homens, mulheres e crianças, de diferentes grupos étnicos e/ou sociais partilham o dia-a-dia dos grupos de capoeira. A mudança de perfil também passa a afetar paulatinamente os mestres encarregados da transmissão da capoeira tradicional.

Enquanto a maioria dos velhos mestres era de pessoas de origem muito humilde com um nível mínimo de escolaridade, é cada vez mais comum encontrar universitários e/ou militantes políticos com sólidos conhecimentos formais entre as figuras de lideranças da nova geração. Com efeito, trata-se de capoeiristas formados durante o período posterior aos anos 80, quando a capoeira assume suas vocações éticas e políticas em consonância com o movimento negro e com o resgate da africanidade na narrativa identitária baiana ${ }^{12}$.

11 Dados recolhidos em pesquisas de campo nos grupos Nzinga e Fica (ZONZON, 2001) e em grupos de capoeira angola no exterior. (ARAUJO, 2004)

12 É muito relevante a atuação do Grupo de Capoeira Angola Pelourinho - GCAP na formação dessas novas gerações de capoeiristas e mestres, uma vez que foi através 
A partir dos anos 90, o universo da capoeira angola começa também a incorporar em seu repertório ideológico a temática feminista. Ocorrem os primeiros encontros de mulheres angoleiras ${ }^{13}$ e a maioria dos grupos integra no seu calendário de eventos o dia 8 de março, comemorando o dia internacional da mulher com rodas femininas, palestras e debates.

Se os dados quantitativos e os marcos cronológicos desse fenômeno de heterogeneização dos grupos de capoeira da Bahia (capital e Recôncavo) atestam a dimensão desse processo e seu crescimento rápido, faz-se, no entanto, necessário um conhecimento aprofundado e minucioso da ressignificação da capoeira angola para que possamos associar tais alterações às mudanças que acontecem simultaneamente no âmbito dos valores veiculados pela prática.

É relevante ressaltar que as características das novas gerações de capoeiristas se encontram amenizadas, quando não omitidas, nas proclamações identitárias que sustentam o processo de recriação de uma capoeira negra e ancestral. Tanto nos discursos elaborados pelas lideranças - que associam cada vez mais a prática da capoeira angola a suas raízes culturais e religiosas africanas ou afrobrasileiras - quanto nos estudos que abordam a temática da capoeira, as discussões se concentram nas questões de origem e de herança.

Procura-se enfatizar uma continuidade e a associação entre capoeira e tradições culturais africanas constitui-se como principal argumento e eixo para a identidade étnico-política proclamada. $\mathrm{Ou}$ ainda, no caso das pesquisas desenvolvidas no âmbito acadêmico,

da criação desse grupo que se deu início ao processo de revitalização da capoeira angola em Salvador e à dimensão de resistência cultural assumida desde então pelos grupos.

13 Os principais eventos internacionais reunindo mulheres praticantes da capoeira angola foram: I Encontro de Angoleiras em Washington - 1997; I Encontro de Angoleiras do Rio de Janeiro - 2002; I Encontro Europeu de Angoleiras - março de 2006. 
conceitos tais como os de descendência, de matrizes e de resistência norteiam as abordagens e justificam a escolha das fontes.

Ora, a hipótese à qual aderimos na reflexão aqui proposta é que a identidade étnica do capoeirista "angoleiro" é o fruto de uma construção complexa, que não se deixa encerrar nos aspectos lineares conotados na argumentação da continuidade ou sobrevivência de uma "tradição".

No atual contexto em que se encontra reunida tamanha diversidade de praticantes, uma análise da ressignificação da capoeira angola precisa levar em conta o papel das diversas agências na reconstrução das estruturas organizacionais e dos valores que sustentam a prática, isto é, deter-se nas mudanças que afetam a dinâmica dos modos de transmissão e de execução do jogo.

\section{SER ANGOLEIRO: A FORMAÇÃO DE UM ETHOS}

O enfoque proposto neste capítulo põe em destaque os fazeres, o corpo e o movimento como principais instâncias de conhecimento da prática e de suas mudanças. Entende-se que, por se tratar de uma prática intensamente corporal, de um universo no qual o mais nuclear transmite-se, adquire-se e desdobra-se também para aquém da linguagem articulada por meio de palavras e da percepção reflexiva, o recurso ao dito não esclarece a lógica prática desempenhada nos modos de agir dos atores. (BOURDIEU, 1980, 2000; WACQUANT, 2002)

É preciso lembrar que são principalmente os aspectos idealizados da prática que fundamentam o que os mestres - e os capoeiristas em geral - costumam designar como "filosofia" ou "fundamentos" da capoeira, ou seja, elaborações discursivas que abrangem desde a sua história até seus princípios e significados. São construtos que apresentam a capoeira como uma comunidade 
simultaneamente mítica, histórica e política e que também alimentam grande parte dos estudos enfocando essa temática.

Contudo, ao levar em conta os dados empíricos concernentes à composição heterogênea dos grupos, abre-se uma nova possibilidade de abordagem desse universo que põe em destaque o trabalho contínuo, sistemático e progressivo de incorporação de valores e sentidos tidos como herdados de determinados grupos étnicos e sociais.

Pode-se, assim, desnaturalizar o fenômeno de transmissão tradicional, detendo-se sobre os processos de transmissão e de realização da prática da capoeira em grupos estruturados e estrategicamente articulados com os contextos local e global de nossos dias. Nessa perspectiva, procura-se trazer à luz os aspectos da prática que apontam para modos específicos de se relacionar com o outro e fornecem, nesse sentido, algumas pistas para o entendimento do reforço de uma identidade étnica coesa num contexto tão marcado pela convivência com a alteridade.

Através de uma pesquisa participante em grupos de capoeira angola de Salvador ${ }^{14}$, foi possível observar alguns dos mecanismos de incorporação de valores inerentes ao processo de aprendizagem que propiciam um entendimento da formação de um ethos do capoeirista, ou seja, de aspectos morais e éticos que produzem (e são produzidos) pelas escolhas práticas. (BOURDIEU, 2002) Uma análise minuciosa ${ }^{15}$ da dinâmica dos "treinos" ou "aulas de movimentos", retomando expressões usadas no meio, assim como das rodas e outros momentos/espaços de iniciação do capoeirista,

14 Trata-se da Dissertação de Mestrado em Ciências Sociais de Christine Nicole Zonzon, intitulado A roda de capoeira angola: os sentidos em jogo.

15 A metodologia adotada na pesquisa acima citada inspirou-se da técnica da "participação observante" de Wacquant. A autora, que se iniciou à capoeira desde o fim da década de 80, lançou mão de uma observação em dois grupos em que pratica ou já praticou a capoeira. Procurou, assim, somar perspectivas internas e externas no sentido de alternar o "fazer" com o "ver" e de interpretar o visto e o dito no "campo" através dos conhecimentos elaborados na própria experiência, submetidos a uma análise inspirada da sociologia da ação prática de Bourdieu. 
traz à tona a profundidade e a abrangência dos saberes adquiridos ao longo desse processo. Não se trata apenas de aprender golpes de ataque e defesa ou habilidades puramente físicas e técnicas, mas sim de incorporar modos de ser, sentir e interagir com o mundo ${ }^{16}$.

Por esse motivo, a iniciação à capoeira angola se dá através de um processo de aprendizagem de longa duração $0^{17}$ em que os aprendizes capoeiristas concentram seus esforços em romper com disposições já constituídas: reflexos instintivos, condicionamentos e limitações físicos e emocionais, etc. Com efeito, tornar-se capoeirista consiste num primeiro momento em desconstruir hábitos e costumes; abrir mão de referências, certezas e seguranças; perder competências, status, posições.

Tanto os aspectos que dizem respeito às técnicas corporais quanto os modos de transmissão da capoeira pouco (ou nada) têm a ver com outros processos de aprendizagem (esportivos, escolares, formais) que o aluno possa ter vivenciado anteriormente. Os movimentos e posições que se dedica a executar nunca foram experimentados antes e dependem de uma reorganização física e perceptiva. O jogo de angola envolve uma movimentação do corpo "rente ao chão", muitas vezes em posição invertida (ponta-cabeça), em que braços e cabeça passam a ser ponto de apoio e sustentação do corpo no lugar dos membros inferiores. Deslocar-se, perceber o espaço e o outro nessas posições envolve uma reorganização do próprio corpo e das funções associadas a determinadas partes ${ }^{18}$,

16 Nessa mesma perspectiva inspirada da fenomenologia, pode ser consultado o estudo do antropólogo e capoeirista americano Greg Downey (2005), que analisa as mudanças do ser ocorrendo através do processo de iniciação à capoeira.

17 É característica da capoeira angola a lentidão do ritmo de aprendizagem, também associado à lentidão do ritmo musical e da execução dos movimentos. Um capoeirista demora em torno de 20 anos para tornar-se mestre; um aluno novo pode passar de 3 a 6 meses treinando apenas os primeiros movimentos, e são geralmente necessários anos para aprender a tocar berimbau com destreza.

18 Nesse conjunto de novas atribuições corporais, é notável a ressignificação dada à cabeça, que deixa de ser a parte "alta" do corpo, nos sentidos físico e simbólico. 
assim como a aquisição de novos hábitos de percepção - notadamente do olhar -, além, é claro, da agilidade e do equilíbrio.

As "aulas de movimentos" prescindem de explicações sistematizadas concernentes ao modo de realização correto ou eficiente das posições e dos golpes, restando ao aprendiz o recurso à imitação de múltiplos modelos que vê em sua volta, mas cujas execuções aparecem, num primeiro tempo, como resultado de operações múltiplas e complexas que ele não consegue decifrar.

$\mathrm{Na}$ roda, percebe que existem certas modalidades de comportamentos a serem seguidas e que regem tanto as interações de jogo em dupla quanto a atuação na bateria musical, porém não são enunciadas regras a respeito do que ele deve ou não deve fazer. Ou ainda, as regras enunciadas são contraditórias entre si ou destoantes com as atitudes que ele observa entre os demais componentes.

A opção entre modos de interagir reflexivos ou espontâneos nas interações com o adversário ilustra bem esse conflito, pois suscita conselhos e orientações contrários dos mestres, seja durante o treino, seja durante o próprio jogo: "Pense! Pare para pensar no que você está fazendo!” versus "Não pare, não!, Não dá tempo para pensar!”.

Quanto às inúmeras regras restritivas ou proibitivas que o iniciante ouve ao longo da sua aprendizagem (jogar apenas na sua vez e sem escolher o seu par; "mostrar" o golpe em vez de aplicálo; ou o próprio uso obrigatório da "farda"), aplicam-se de forma diferenciada em função do status de cada capoeirista, status esse que não é evidenciado por qualquer marco distintivo, além de ser relativamente flutuante ao favor de configurações de posições no espaço simbólico.

Rompendo com a oposição corpo versus cabeça, passa a assumir, além do papel de sustento do corpo, a função de uma "massa corporal" a ser projetada contra o adversário no famoso golpe da cabeçada, tido pelos angoleiros como um dos mais nobres do jogo. 
Percebe-se assim que se trata de um tipo de aprendizagem por imersão e convivência numa coletividade, ou seja, é através das experiências corporal e sensorial propriamente ditas, partilhadas num meio em que todos se dedicam a aprender e praticar a capoeira, que se constituem novos habitus. As alterações e ressignificações dos esquemas corporais e perceptivos resultam em uma nova "crença prática"19, as mudanças afetando os comportamentos e valores dos praticantes de modo relativamente independente das suas convicções ideológicas. Sendo assim, a identidade de capoeirista extrapola o universo restrito do exercício da prática propriamente dita, fazendo com que um capoeirista - ou, no caso, um angoleiro - não deixe de sê-lo nos demais ambientes e momentos do cotidiano. Dito de outra forma - na própria linguagem dos mestres - "ser angoleiro não é apenas ser um jogador de capoeira, ou ainda não é só jogar as pernas para cima” ${ }^{20}$.

A pesquisa citada permitiu esquematizar alguns princípios fundamentais transmitidos implícita ou explicitamente no processo de iniciação à capoeira e que delineiam o ethos do capoeirista: a inversão; a circularidade; a alternância entre distância e aproximação, entre outros. Esses princípios práticos aparecem sob diversas formas nas também diversas vertentes da aprendizagem que compõem o universo da capoeira angola: as aulas de movimentos; a aquisição do repertório musical das cantigas e dos modos de tocar os instrumentos; os comportamentos, os papéis e seu revezamento na hora da roda; o jogo com o outro; além dos ensinamentos orais que pontuam cada um desses momentos.

19 “A crença prática não é um estado d'alma ou, menos ainda, uma sorte de adesão decisória a um corpo de dogmas e doutrinas instituídas ('as crenças'), mas, se me permitem a expressão, um estado de corpo. A doxa originária é esta relação de adesão imediata que se estabelece na prática entre um habitus e o campo ao qual está acordado, esta experiência muda do mundo como que evidente [allant de soi] que o senso prático propicia” (BOURDIEU, 1980, p.115, tradução nossa, grifo do autor).

Ambas as formulações são motes da transmissão oral de mestre a aluno. 
Um mesmo princípio como a inversão opera no campo prático físico (no movimento da bananeira, por exemplo); no nível perceptivo do olhar (que vê o mundo de baixo para cima); no domínio das emoções (sentir medo/expressar valentia); no jogo entre dois capoeiristas (o fraco derruba o forte); no sentido conotado de uma cantiga (grande pequeno sou eu) e no manejo prático de um instrumento (o dedo mínimo sustenta o berimbau, maior instrumento em termos de poder simbólico), etc.

Assim, podemos falar de um ethos do capoeirista no sentido de valores que são incorporados sob a forma de um repertório físico e moral, ético e estético e que estruturam o jogo da capoeira. Esses princípios práticos, que não são necessariamente escolhidos ou percebidos reflexivamente, delineiam modos prático e simbólico de se relacionar com o outro e com o mundo. Também correspondem àquilo designado, nos termos próprios aos capoeiristas, como "malandragem" ou "mandinga", que se traduzem, na prática do jogo da capoeira, por expressões lúdicas e estéticas, pela imprevisibilidade das ações e a capacidade de iludir.

\section{DA MALANDRAGEM À MANDINGA}

Ao introduzir esses dois termos, entramos em contato com a diversidade de conotações que podem ser associadas a esses princípios, ou seja, abordamos a dimensão ética que permeia essa (e qualquer) prática. Com efeito, se essas designações evocam atributos que em outros contextos eram (ou são) associados a uma falta de caráter ou ao uso de procedimentos legalmente ou moralmente repreensíveis ${ }^{21}$, servem, no universo dos grupos

21 Os artifícios dos capoeiristas eram também designados pelo nome de traição pelos "capoeiras" de outrora, o que evidencia mais ainda a conotação de imoralidade subjacente aos critérios de excelência do capoeirista. Sobre a terminologia dos capoeiristas de outrora, ver os manuscritos de Mestre Noronha. (COUTINHO, 1993) 
de capoeira angola, para caracterizar as figuras de excelência do angoleiro. Usados pelos capoeiristas quase como sinônimos, originam-se em universos particulares. $\mathrm{O}$ da malandragem, que remete diretamente a sujeitos sócio-historicamente situados ${ }^{22}$, e o da mandinga, cujas conotações são mais misteriosas, vinculadas a práticas mágico-religiosas ${ }^{23}$.

Em muitos estudos históricos ou antropológicos sobre a capoeira, assim como nas elaborações discursivas dos capoeiristas sobre a sua própria prática, mandinga e malandragem são entendidos como heranças das tradições passadas e explorados no sentido de vincular as formas modernas da capoeira com seus antepassados africanos, afro-brasileiros e/ou com formas de resistência dos segmentos marginalizados da população. Estas abordagens ressaltam as origens dos ritos da capoeira e evidenciam as permanências e ressignificações das suas práticas e símbolos nas realizações contemporâneas.

Do ponto de vista dos processos e códigos de aprendizagem do corpo, das percepções e das emoções que constituem o eixo da presente investigação, os legados da malandragem, enquanto modo de sobrevivência de camadas marginalizadas da sociedade brasileira do início do século XX, ou ainda da mandinga, compreendida no sentido de práticas mágicas de origem africana, constituem elementos importantes enquanto criações e representações que canalizam os valores experimentados no universo da capoeira.

Ora, embora os jogos representativos - que os capoeiristas costumavam chamar de falsidade, maldade e malandragem e que se constituem como heranças da capoeira marginalizada de outrora - estejam presentes na linguagem corporal do capoeirista de hoje, observa-se uma reiteração cada vez maior do uso do termo e

22 Para uma análise do malandro como personagem paradigmático da sociedade brasileira, ver Da Matta (1997)

23 Sobre a origem do termo mandinga, ver Zonzon (2001). Sobre relações históricas entre malandragem e mandinga nas práticas da capoeira, ver Dias (2006). 
das figuras da mandinga como valor ético e estético proclamado e realizado nos grupos da capoeira angola contemporâneos.

Tal deslocamento - da malandragem para a mandinga - inserese entre os elementos que configuram a ressignificação da capoeira angola no sentido de uma (re)africanização e de uma ritualização da prática. De fato, tem-se observado, ao longo dos últimos anos, algumas alterações no processo de aprendizagem e na realização do ritual da roda que tendem a pôr em destaque o vínculo tradicional entre capoeira e religiosidade africana. Entre outros elementos, pode-se citar a incorporação mais sistemática, no âmbito do repertório corporal, de posturas e gestos inspirados do candomblé; a inclusão no repertório das cantigas de um número significativo de cantos em língua banto; o recurso ao conceito de "linhagem" para representar as gerações sucessivas de mestres; a promoção da participação de especialistas religiosos do candomblé nos eventos de capoeira e, de modo geral, uma maior ênfase, nos discursos, sobre as ligações entre capoeira angola, tradição africana e espiritualidade.

As representações construídas em torno do berimbau ilustram bem essa vertente interpretativa. A afirmação do valor simbólico do berimbau enquanto instrumento sagrado vem paulatinamente substituir-se a outra narrativa a seu respeito, que retratava o seu uso enquanto arma, na época da repressão à capoeira, quando capoeiristas revidavam às investidas da polícia com vigorosas berimbadas ${ }^{24}$.

$\mathrm{Na}$ contemporaneidade, todos os cuidados que rodeiam o manejo do instrumento - armar ou desarmar o berimbau sem nunca inverter a posição vertical com a cabaça para baixo, reservar as tarefas de afinação dos berimbaus e de substituição desses

24 Segundo relato de Mestre Noronha, a verga do instrumento podia virar um cacete e a vaqueta, varinha com a qual é percutido o arame - servia para furar o inimigo. Mestre Pastinha, por sua vez, conta que usava uma foicezinha encaixada no cabo do instrumento "praqueles que quisesse me ofender". (COUTINHO, 1993; PASTINHA, 1988 apud DIAS, 2006) 
instrumentos durante a roda à carga dos alunos de maior prestígio, etc. - enfatizam a sua função simbólica e tendem a fazer esquecer seus antigos aproveitamentos práticos. Os relatos da capoeira de antigamente, retratos da malandragem, que até recentemente compunham a história oral da capoeira transmitida pelos velhos mestres, cedem hoje diante das representações da capoeira numa conotação cultural ou espiritual.

Por outro lado, a africanização da capoeira, o reforço da mandinga em detrimento da malandragem como valor ético e estético dos jogos pode ser associado à alteração das composições dos grupos caracterizado pelo ingresso de categorias não tradicionais no universo da capoeira.

É relevante lembrar que a imagem da malandragem evoca o modelo masculino do "valentão" - traduzido na gestualidade do desafio - que apresenta características dificilmente conciliáveis com a identidade moderna da capoeira. O público infantil e juvenil recentemente incorporado nos grupos de capoeira através de programas educativos e socioculturais, por um lado, e a feminilização dos grupos (associado também, como já ressaltado, à internacionalização) parecem impulsionar um arrefecimento das figuras do machismo e da violência vinculadas historicamente ao ethos da malandragem.

Isso não significa que os velhos valores tenham sido erradicados da capoeira angola. É preciso lembrar que os gestos, posturas e expressões que constituem a forma prática designada aqui como ethos não se transformam na mesma medida ou no mesmo ritmo que os princípios teóricos ${ }^{25}$, o que tem garantido uma inegável vitalidade do ethos masculino nas práticas ritualizadas da roda de capoeira angola.

25 Segundo Bastide, é o fenômeno da prevalência da memória corporal, ou memória motora, sobre a memória intelectual que explica a permanência e a ressignificação de ritos e práticas de origem africana no contexto de transformações das estruturas sociais. (BASTIDE, 1995) 
Contudo, é notável o crescimento de uma eufemização e simbolização da violência na roda de capoeira, assim como uma certa descontração do machismo à medida que as mulheres assumem um papel cada vez mais significativo em termos de número e de participação e acessam a posições de lideranças ${ }^{26}$.

Com o ethos da mandinga e o apelo à africanidade, o espaço da mulher no universo da capoeira adquire novas conotações. De fato, as representações vigentes a respeito do universo cultural africano destacam a importância do papel feminino em termos de lideranças nos âmbitos religioso e comunitário (notadamente o destaque conferido ao matriarcado). Dessa forma, fica delineado um dos percursos de ressignificação da capoeira no sentido de encontrar na identidade africana uma narrativa que possa reinterpretar os valores contemporâneos trazidos pelos novos entrantes no meio.

Nessa perspectiva, o mote da mandinga parece capaz de transcender a aparente oposição entre a ética moderna do direito e da igualdade (das mulheres, entre outros) e os legados de uma tradição em que se fundamenta no poder masculino. A narrativa identitária da "africanidade" da capoeira abre, portanto, nos discursos e na prática, uma possibilidade de sintetizar traços de gênero e de etnia, no âmbito de uma representação que permanece tradicional ou, de certa forma, se torna mais tradicional ainda.

Com o caso da inserção da mulher no universo da capoeira, apresentamos uma interpretação da ressignificação da identidade ocorrendo na contemporaneidade, nos grupos de capoeira angola

26 No decorrer da pesquisa em dois grupos de capoeira angola, vindo da mesma linhagem e cujos mestres foram formados na mesma época, observou-se que os jogos mais violentos, as práticas de discriminação à mulher e de machismo persistiam com mais vigor no grupo liderado por um homem, enquanto, no grupo em que a liderança era partilhada entre mestres de ambos os sexos, essas atitudes tendiam a desaparecer. Em ambos os grupos, tendo uma ampla participação feminina entre seus membros, destaca-se a importância do acesso da mulher à posição de mestre como principal fator de mudança. 
de Salvador. É preciso ressaltar, mais uma vez, que muitos dos grupos continuam, mesmo assim, transmitindo sua filosofia, ou seus fundamentos, interpretados através de uma leitura da tradição que preserva o poder e a autoridade masculinos; entretanto, a questão feminina consta entre as pautas de discussão dos grupos e suscita acirrados debates e reflexões sobre tradição, autenticidade e poder. Assim, percebe-se que a inserção de novos atores reivindicando novos valores cria uma situação de conflito que pode ser entendida em termos de luta entre postulantes e dominantes, conforme a análise de Bourdieu a respeito da estrutura e da dinâmica dos campos ${ }^{27}$.

A perspectiva de uma luta pelo poder é pertinente e esclarecedora nessa reflexão, já que os grupos de capoeira angola são estruturados verticalmente - em termos de saber e de poder - da posição mais alta à mais humilde em função do tempo de permanência e da consequente experiência dos seus componentes. Dito em outras palavras, no topo da hierarquia encontra-se o mestre ("os mais velhos”), enquanto o nível mais baixo está ocupado pelos novos entrantes ("os mais novos"), entre os quais encontramos, quase sistematicamente, os capoeiristas dos estratos não tradicionais. Assim, nesse tipo de organização, mulheres, estrangeiros, crianças e outros participantes que aderiram mais recentemente à prática da capoeira encontram-se afastados das instâncias de poder e decisão dos grupos (compostos não só pelo mestre como também pelos alunos que contam mais tempo de permanência no grupo).

Como vimos acima, esse sistema sofre certo abalo à medida que os novos entrantes oriundos de outros espaços geográficos e sociais exercem uma pressão no sentido de os grupos contemplarem valores inerentes à modernidade. A sobrevivência da capoeira

27 Nos termos de Bourdieu, o campo é definido como "um espaço estruturado de posições cujas propriedades dependem da sua posição nestes espaços; em que agentes ou instituições lutam pela conservação ou a subversão da estrutura de distribuição do capital específico". (BOURDIEU, 2002, p. 114, tradução nossa) 
e sua expansão no contexto contemporâneo estão atreladas à possibilidade de esse novo público se identificar com as representações éticas e estéticas proclamadas no meio, uma vez que a quase totalidade dos grupos depende hoje da participação desse público diversificado. Por outro lado, esses capoeiristas originários de categorias não tradicionais na capoeira baiana, que até uma época muito recente ocupavam uma posição de outsider ${ }^{28}$ nesse universo, acessam progressivamente a posições de mais status, pelo simples passar do tempo, sinônimo de ascensão na escala dos saberes e poderes.

Nesse contexto também afetado pela intervenção do Estado através das políticas culturai ${ }^{29}$, os grupos enfrentam o desafio de se modernizar sem abrir mão daquilo que consideram nuclear e essencial na sua prática e que garante o poder das suas lideranças: a tradição. Trata-se, assim, de desenvolver uma dinâmica de relação com a alteridade, e é dentro da lógica da capoeira e recorrendo aos próprios princípios básicos do jogo que vai ser buscada uma resposta no modo de uma negociação de espaço.

28 Utilizamos o termo de outsider emprestado de Norbert Elias (2000) para qualificar os capoeiristas forasteiros, isto é, oriundos de grupos sociais não tradicionais no universo da capoeira (mais especificamente mulheres, jovens de classe média, intelectuais e estrangeiros). Cunhada pelo sociólogo em oposição ao termo de estabelecidos, a designação outsider põe em destaque as relações de poder associadas ao critério de anterioridade da inclusão no meio.

29 Pesam também significativamente, nesse processo, as políticas públicas implementadas nas últimas décadas, quando a valorização e o reconhecimento da capoeira como patrimônio cultural implicam a adesão a valores democráticos da cidadania, da não violência e da igualdade. Essa vertente da patrimonialização da capoeira vinculada às políticas na área do turismo mereceria uma análise específica cujo foco escapa à abordagem desenvolvida neste capítulo. 


\section{O JOGO COM A ALTERIDADE}

Voltando aos princípios práticos que subtendem o jogo de angola e, simultaneamente, fundamentam o ethos do capoeirista, encontramos uma série de instrumentos estratégicos que visam a mediar um confronto entre dois jogadores num espaço físico reduzido, qual seja o círculo desenhado pela roda de capoeira. A inversão, a circularidade (ou modos indiretos de aplicar golpes e de elaborar estratégias) orientam o desempenho corporal da dupla, conferindo seu formato peculiar ao movimento dos corpos e caracterizando também suas atuações morais, suas expressões emocionais, em suma, conferindo um sotaque singular à interação, o qual, como vimos, pode ser designado pelos termos "malandragem" e "mandinga".

A capoeira angola não é um esporte e consequentemente a luta na roda não termina com a vitória de um dos capoeiristas. Não existem ganhador e perdedor; na realidade, nem mesmo existe uma "luta", pois fala-se em jogo ou, nos termos mais antigos, em "brincadeira" ou "vadiação"30. Mesmo assim, cada um dos jogadores e o conjunto dos participantes à roda tem a percepção de quem está "levando" ou "dominando" o jogo.

Vale a pena deter-se mais detalhadamente sobre essa interação em que se encontram metaforizadas as modalidades e os critérios de uma disputa pela dominação dentro dos parâmetros práticos, éticos e estéticos, dos angoleiros. Na terminologia própria ao campo, os modos de interagir no jogo através de movimentos

30 Em contrapartida à natureza lúdica expressa nessas designações, é ressaltado o caráter de seriedade do jogo quando se alude à sua periculosidade através de constantes advertências dirigidas pelos mestres a seus alunos, notadamente nos versos improvisados, incorporados às cantigas: jogue com muito cuidado; quem não pode com mandinga não carrega patuá, etc. Trata-se portanto de uma brincadeira que pode desencadear consequências reais: ferimentos do corpo (os mais frequentes sendo torções e fraturas, mas alguns golpes podem ser mortais) ou da alma (a ridicularização, a perda de status). 
corporais são designados como "diálogo corporal", tendo cada movimento da interação entre os dois adversários o valor de "pergunta" e/ou "resposta" (em vez de golpes de ataque e defesa e/ou contragolpes).

Numa outra formulação frequente, a capoeira angola, no seu conjunto, seria uma linguagem diferente de outras - a da capoeira regional sendo o contraponto mais explorado na argumentação. Ainda no mesmo campo lexical, fala-se, por sua vez, do "estilo" herdado de cada jogador, que é herdado, por sua vez, do "estilo" de cada grupo.

O encontro com o "outro" comporta como duplo desafio conseguir dialogar com uma linguagem diferente sem deixar de conservar a sua própria "linguagem de jogo". Trata-se de "fazer seu próprio jogo", "não entrar no jogo" ou no ritmo do outro, independentemente das incitações ou provocações do adversário.

Essa complexa linguagem do corpo que associa técnicas como golpes e acrobacias, o ritmo dançado da ginga e expressões teatrais e que varia de pessoa para pessoa e de grupo para grupo deve então reunir os atributos aparentemente contraditórios de expressar uma identidade própria (ao jogador ou ao grupo) e habilitar o capoeirista para que se comunique com qualquer adversário. Com efeito, a excelência do angoleiro repousa fundamentalmente na sua aptidão para interagir com qualquer outro jogador. Uma das características mais surpreendentes do jogo da capoeira angola reside justamente na capacidade de adaptação do jogador a cada nova interação em dupla. O parceiro/adversário do jogo na roda pode ser grande ou pequeno, homem ou mulher, um novato experimentando sua primeira roda ou um exímio jogador, uma criança ou ainda um senhor de idade. Ao contrário das modalidades esportivas ou das artes marciais que organizam suas competições conforme categorias de participantes visando a propiciar uma igualdade das chances, é justamente a aleatorieda- 
de das duplas de jogadores que alimenta os princípios práticos e éticos da roda de capoeira.

Nessa perspectiva, a excelência do angoleiro envolve uma competência em se relacionar com a alteridade sem perder suas referências e valores próprios, o que, na atual situação de extrema diversificação dos componentes dos grupos, garante a possibilidade de interagir com uma alteridade mais exacerbada do que no contexto tradicional.

Se adotarmos como ponto de vista os princípios e fundamentos do jogo de angola, o confronto entre capoeiristas tradicionais e outsiders que compõem os grupos de capoeira de nossos dias reproduz os formatos da própria interação na roda: é uma luta indireta, disfarçada e ambígua. À imagem das estratégias corporais do angoleiro, as relações e interações entre detentores da tradição e do poder e as novas categorias de capoeiristas seguem uma dinâmica de avanços e recuos, de aproximação e distância.

É o “jogo de dentro/jogo de fora”, expressão que caracteriza o modo específico de negociação de espaços entre jogadores, quando estes alternam recuos com invasões do espaço corporal do adversário. Essa imagem retrata, a nível simbólico, o jogo de inclusão/ exclusão das categorias de pertencimento dos grupos.

No decorrer da investigação, observou-se que os capoeiristas designam seus pares, membros de outros grupos através do termo “irmãos" por se tratar de angoleiros de uma mesma linhagem (no caso, descendentes de Mestre Pastinha), porém também são chamados de "visitantes de fora" quando se quer acentuar a singularidade e a coesão do grupo. Igualmente, a depender dos contextos e das situações, os outsiders ocupam uma posição de exterioridade ou, pelo contrário, são incluídos na identidade comum. Esta aparente contradição entre a afirmação de um vínculo marcado pelo pertencimento a uma mesma "família" (termo também usado para falar do grupo ou do conjunto de grupos liderados por mestres 
“irmãos”) e, em paralelo, o uso da designação "visitantes de fora”, que remete a uma relação de exterioridade, traduz a instabilidade das categorias de referência das quais se lança mão no universo da capoeira.

Se enfocarmos a organização "política" dos grupos de capoeira angola, notamos que, embora apresentem uma estrutura hierarquizada aparentemente irreversível, já que é o critério de antiguidade que estrutura a escala dos poderes, e que o título de Mestre é concedido pelo mestre do postulante, existem, concomitantemente à rigidez do esquema, alguns mecanismos de alternância do exercício do poder.

O momento/espaço da roda propicia a possibilidade de deslocamento dos capoeiristas entre posições e papéis, quando todos se revezam para ocupar os diferentes ofícios na bateria musical, no coro e no jogo, assumindo consequentemente os valores simbólicos inerentes a esses postos ${ }^{31}$.

Nesse sentido, a movimentação no espaço físico da roda, percebida como metáfora das configurações de posições simbólicas, ajuda a compreender as variações afetando o status dos membros ou das categorias de membros no grupo. Retomando o exemplo da participação da mulher, observa-se que o trato dado às capoeiristas oscila entre manifestações de desprezo ou mesmo de violência (simbólica ou real) e uma valorização da presença e da atuação femininas. É o conjunto dos participantes e a configuração de suas posições respectivas que condicionam o espaço que lhe será reservado, em cada roda ou mesmo em cada jogo.

31 Em paralelo à escala hierárquica do grupo que vai (de cima para baixo) do mestre ao mais recém-chegado, a bateria musical associa posições de poder ao manejo dos instrumentos, sendo os berimbaus os mais prestigiosos e poderosos e, entre eles, o berimbau mais grave, o gunga, também chamado de "berimbau mestre". Quem estiver tocando este berimbau está comandando a roda. Vale ressaltar que a partilha da autoridade propiciada por esse formato encontra seu limite na exigência de uma competência específica para se tocar esse instrumento, o que reduz o leque de capoeiristas que se propõem, no decorrer da roda, a assumir essa posição. 
As fronteiras que delimitam o pertencimento à comunidade se estreitam ou alargam em função das figuras de lideranças que se encontram presentes e de suas interpretações mais ou menos flexíveis da tradição. Esse movimento de contração/expansão da identidade não deixa de lembrar aquele que afeta os contornos da roda no espaço físico: a pedido do mestre, o círculo se aperta para diminuir a área do jogo e propiciar assim um estilo mais fechado (o jogo de dentro); em seguida, com a chegada de mais participantes à roda, a circunferência se estende, abrem-se lugares para os recém-chegados sentarem, expandindo-se a superfície em que ocorre o jogo...

Por certo, esses atributos de flexibilidade, as habilidades no âmbito da negociação e o famoso "jogo de cintura" do capoeirista asseguram a capacidade de adaptação dos grupos e da prática aos contextos da contemporaneidade, como já garantiram a sobrevivência da capoeira em épocas de repressão e perseguição. No mundo da ambiguidade e do faz de conta, nada se delineia com contornos claramente definidos nem se pretende um valor de verdade definitiva.

Daí também decorre a dificuldade em definir precisamente quais seriam seus valores ou mesmo seu formato próprio. A capoeira se mostra tão escorregadia quanto o próprio angoleiro. Joga prá lá e prá cá, ginga ao favor das circunstâncias e das necessidades: é arte, luta de resistência, religião, educação, pesquisa; é banto, africana, baiana, internacional.

\section{ANGOLEIRO NA PEQUENA RODA E BAIANO NA GRANDE RODA}

O exposto acima permitiu esboçar alguns traços do ser "angoleiro" em que se destaca uma extrema vitalidade sustentada 
por uma estrutura de grupos organizados e hierarquizados e por um sistema de ensino iniciático de longa duração. Esse formato tem se mostrado eficiente na tarefa de assegurar a transmissão de saberes nos contextos diversificados decorrentes da expansão da capoeira. Como se viu, as ressignificações da prática, exigidas por essas mudanças, inserem-se na própria lógica do sistema, sendo os valores "modernos" traduzidos na linguagem do universo da capoeira, isto é remetidos sempre a uma tradição.

Também é relevante destacar que a dimensão simbólica e ideológica da capoeira se encontra estreitamente imbricada numa dimensão corporal e prática, a qual gera modelos e ações que se situam, se não em oposição, digamos, em margem dos quadros lógicos da racionalidade moderna.

De fato, trata-se de um universo cuja compreensão escapa às polaridades do pensamento convencional, pelo modo singular com que desconstrói as oposições entre categorias geralmente tidas como antitéticas: adversário/parceiro; forte/fraco; dentro/fora; em cima/embaixo, etc. Enfim, é bastante esclarecedor lembrar que, para o angoleiro, o critério máximo de excelência é o faz de conta, qual seja, a habilidade em transcender as fronteiras entre real e representação!

Não há de surpreender, então, que os capoeiristas encontrem na representação de uma África imaginada, fora do espaço e do tempo e envolta na magia da mandinga, uma fonte de inspiração e de identificação. Na contramão das tendências à uniformização dos costumes e dos sentidos desencadeadas pelo processo de globalização da cultura, o recurso a uma africanidade mítica vem dar consistência e conceder suas letras de nobreza a uma manifestação cujas formas ainda são marcadas pela discriminação de um passado recente e que se torna cada vez mais vulnerável diante das ideologias do politicamente correto. 
Assim, a reatualização da memória dos antepassados africanos permite situar a capoeira num outro sistema de referências e representações, imune às pressões da contemporaneidade global. A África dos angoleiros aparece, nesse sentido, como possibilidade de ser e fazer diferente (da norma e dos valores dominantes modernos), como expressa uma cantiga, criada nos anos 80 por Mestre Moraes, um dos principais atores da revitalização da capoeira angola na Bahia: Angola, Angola/tudo é diferente em Angola.

Sob esse ponto de vista, ser negro, ser africano, ser tradicional são atributos que se apresentam como elementos de legitimação de uma diferença, o que se traduz nos discursos políticos e ideológicos das lideranças dos grupos pela proclamação de uma resistência. É pertinente pensar que os processos de expansão e de internacionalização da capoeira, assim como as novas políticas públicas na área da cultura que resultaram no seu tombamento como patrimônio cultural do Brasil ${ }^{32}$, tiveram como contrapartida uma ênfase nas narrativas identitárias africana e baiana. Com a reivindicação dessas duas territorialidades, quais sejam, o pertencimento à África, por um lado, e o reconhecimento da Bahia como berço e referência da capoeira, por outro, a capoeira vem se

32 Em algumas vertentes dos discursos oficiais, a capoeira aparece no seu devir internacional/universal como "instrumento de paz entre os povos", ao mesmo tempo em que se procura destacar sua identidade baiana e brasileira. Assim, no discurso do ministro Gilberto Gil em Genebra, em 19 de agosto de 2004, na ocasião de uma homenagem ao embaixador brasileiro da ONU morto em Bagdá, com a presença de vários mestres de Capoeira, encontra-se expresso o esboço inicial das futuras políticas de apoio à capoeira que iriam ser desenvolvidas nos anos ulteriores. "Realizaremos ainda este ano uma reunião com os capoeiristas brasileiros e estrangeiros para delinearmos uma grande ação para a capoeira. Queremos ouvir e assimilar as necessidades e demandas dos diversos capoeiristas: do Brasil e do mundo. [...] Queremos construir um calendário anual, nacional e internacional da capoeira. Criar um Centro de Referência no Pelourinho, em Salvador, que servirá não só de acervo de pesquisas, livros, adornos e imagens, mas também de espaço para atividades. A Bahia, assim, deve se afirmar como uma espécie de 'Meca da Capoeira”'. E depois de chamar os mestres baianos, brasileiros e estrangeiros para o palco, termina o discurso com essas palavras: "Todos esses são provas de que a capoeira pode ser globalizada num mesmo tom... Hehêê: é Paz no Mundo, Camará...”. (GIL, 2004) 
inserir na representação da Bahia como enclave africano no Brasil, sendo, junto com o candomblé, um dos principais ícones de uma baianidade negra e ancestral.

Esse estereótipo, no qual a capoeira ilustra e reforça a narrativa de uma singularidade de traços tais como o predomínio do corpo, da musicalidade e da religiosidade, pode ser interpretado à luz da análise do campo mais restrito da capoeira, isto é, levando em conta as interdependências dos atores e dos grupos postos em contato no contexto contemporâneo. Em tal perspectiva, esses elementos não são mais atribuídos a uma essência natural do baiano, mas sim apreendidos numa dinâmica de resistência diante da imposição de valores modernos decorrente de uma maior abertura da Bahia para o mundo.

Inspirando-se na análise do universo da capoeira angola na Bahia e estendendo a reflexão para o âmbito da construção de uma identidade baiana, os processos de reafricanização e de enraizamento na tradição não retratam um continuum nem se constituem como uma invenção visando a satisfazer e encantar o olhar do outro; integram uma narrativa elaborada pelos próprios protagonistas da cultura baiana para dar legitimidade a suas formas de ser e de agir. Em outras palavras, a baianidade negra e ancestral seria uma vertente de reinterpretação das disposições incorporadas ao longo de um processo histórico em consonância com as configurações éticas e políticas da atualidade.

A hipótese exposta acima toma consistência se retomarmos para nossa conta a analogia entre mundo da capoeira e mundo de fora, que constitui uma das chaves dos ensinamentos incorporados pelo capoeirista. Na visão de mundo do angoleiro, os saberes adquiridos no ambiente restrito da roda de capoeira são estendidos para outras áreas da vida social, sendo a identificação da roda com o mundo real traduzida pelo uso dos dois termos: "pequena roda" (da capoeira) e "grande roda" (da vida real). 
O que se aprende e vivencia na roda de capoeira teria, assim, validade nos demais domínios da experiência, pois o capoeirista passa a recorrer à esperteza adquirida no jogo para orientar seus comportamentos nas mais variadas situações de interação do dia-a-dia ${ }^{33}$.

Detendo-nos sobre as autorrepresentações corriqueiras na caracterização do baiano, observamos que os princípios práticos subjacentes à formação do ethos do capoeirista em nada são estranhos aos hábitos e costumes em vigor na Bahia ${ }^{34}$. Atributos como aquele de se ter "jogo de cintura" que remete, no seu sentido literal, à movimentação corporal da ginga e de muitos outros movimentos característicos do jogo, extrapola o mundo restrito dos praticantes da capoeira para caracterizar certas habilidades de negociação em situações de conflito ou de perigo, atribuídas mais particularmente ao baiano. Ou ainda, a expressão "levar uma rasteira" traduz, na linguagem comum de Salvador, o sentido de ser frustrado na realização das expectativas com relação àquilo que se tomava como garantido, ou colocado numa situação de perda ou insegurança inesperadamente.

Esses exemplos que ilustram a convergência das representações entre o baiano e o capoeirista dão a dimensão das possibilidades de se explorar a análise do caso da capoeira como metáfora de formas singulares de ser cultivadas na Bahia. Essa démarche pode ser expressa, nos termos da sociologia de Bourdieu, no sentido

33 Essa expansão das competências da pequena roda para grande roda nos remete diretamente ao fenômeno bourdieusiano de transferência do habitus, explicitado por Wacquant nos termos seguintes : “[...] uma competência prática [...], transferível para vários domínios da prática, o que explica a coerência que se verifica, por exemplo, entre vários domínios de consumo - na música,desporto, alimentação e mobília, mas também nas escolhas políticas e matrimoniais - no interior e entre indivíduos da mesma classe e que fundamenta os distintos estilos de vida". (WACQUANT, 2004, p. 35)

34 Estamos aqui referindo à Bahia no sentido estrito que é concedido à palavra nas narrativas identitárias da baianidade, qual seja, enfocando apenas a capital e o Recôncavo. 
de aproximar o habitus do capoeirista do habitus do baiano e de interpretar as analogias em termos de transferências de competências práticas ${ }^{35}$.

Mais particularmente, os modos de agir indiretos que constituem uma alternativa ao conflito aberto, o jogo de alternância entre distância e proximidade no trato com a alteridade, uma percepção do tempo que ignora os ritmos apressados da modernidade apontam para uma convergência de ambos os entendimentos do mundo. Também seria esclarecedor elaborar cruzamentos com conhecimentos a respeito de outros universos culturais tradicionais da Bahia em que as mesmas disposições práticas podem ser encontradas. Pensamos notadamente no benefício de se recorrer a estudos do candomblé cujo sistema de transmissão e iniciação evidencia diversos traços comuns com a capoeira angola, além de as duas tradições partilharem, quase simultaneamente, um processo de reafricanização.

Em suma, levando a sério a metáfora da pequena e da grande roda, tratar-se-ia de investigar em que outros ambientes e circunstâncias os baianos jogam esse mesmo jogo: fazendo do encontro com o outro, negociado entre conflito e harmonia, uma oportunidade de recriar-se sob uma face mais autêntica, entendendo-se aqui a autenticidade como aquilo que o corpo vivencia, pois, retomando uma bela formulação de Bourdieu (1980, p. 123): “o corpo acredita no que faz". 


\section{REFERÊNCIAS}

ABIB, Pedro Rodolfo Jungers. Capoeira Angola: cultura popular e o jogo dos saberes na roda. Campinas, São Paulo: UNICAMP/CMU; Salvador: Edufba, 2005.

ABREU, Frederico José de. Bimba é bamba: a capoeira no ringue. Salvador: Instituto Jair Moura, 1999.

ARAUJO, Costa, Rosângela. Iê viva meu mestre: a capoeira angola da "escola pastiniana" como práxis educativa. 2004. Tese (Doutorado em Educação) - Faculdade de Educação, USP, São Paulo.

BASTIDE, Roger. Les amériques noires: les civilisations africaines dans le nouveau monde. Paris: L'Harmattan, 1996.

. Les religions africaines au Brésil: contribution à une sociologie des interpénétrations de civilisations. Paris: Presses Universitaires de France, 1995.

BOURDIEU, Pierre. Esquisse d'une théorie de la pratique: précédé de trois études d'ethnologie kabyle. Paris: Du Seuil, 2000.

. Le sens pratique. Paris: Les Editions de Minuit, 1980.

. Questions de sociologie. Paris: Les Editions de Minuit, 2002.

CASCUDO, Luis da Câmara. Folclore do Brasil. Rio de Janeiro: Fundo de Cultura, 1967.

COUTINHO, Daniel. O ABC da capoeira de Angola: os manuscritos de Mestre Noronha. Brasília: DEFER, Centro de Informação e Documentação sobre a Capoeira, 1993.

DA MATTA, Roberto. Carnavais, malandros e heróis: para uma sociologia do dilema Brasileiro. Rio de Janeiro: Rocco, 1997.

DIAS, Adriana Albert. Mandinga, manha e malícia: uma história sobre os capoeiras na capital da Bahia (1910-1925). Salvador: Edufba, 2006.

DOWNEY, Greg. Learning capoeira: lessons in cunning from an afrobrazilian art. New York: Oxford University Press, 2005.

ELIAS, Norbert. Os estabelecidos e os outsiders: sociologia das relações de poder a partir de uma pequena comunidade. Rio de Janeiro: Zahar, 2000. 
GIL, Gilberto. Discurso do ministro Gilberto Gil em Genebra: Brasil, paz no mundo. Genebra: [s.n.], 19 de agosto 2004. Disponível em: $<$ http://capoeirangolaareiasul.blogspot.com/2007/12/discursoministro-gilberto-gil-em.html>. Acesso em: 5 fev. 2011.

HALLBWACHS, Maurice. A memória coletiva. São Paulo: Vértice, 1990.

REGO, Waldeloir. Capoeira angola: ensaio sócio-etnográfico. Salvador: Itapuã, 1968.

REIS, Letícia Vidor de Souza. O mundo de pernas para o ar: a capoeira no Brasil. São Paulo: Publisher Brasil, 2000.

SOARES, Carlos Eugênio Líbano. A negregada instituição: os capoeiras no Rio de Janeiro 1850-1890. Rio de Janeiro: Secretaria Municipal de Cultura, 1994.

WACQUANT, Loïc. Corpo e alma: notas etnográficas de um aprendiz de boxe. Rio de Janeiro: Relume Dumará, 2002.

. Esclarecer o habitus. Revista da Faculdade de Letras :

Sociologia, v. 14, 2004. série I,

ZONZON, Christine Nicole. Capoeira Angola, construção de identidades: uma investigação sobre as identidades construídas por grupos de capoeira angola em Salvador. 2001. Dissertação (Mestrado em Línguas e Civilização) - Université Stendhal, UFR de Langues, Littératures et Civilisations Etrangères, Grenoble, França. . A roda de capoeira angola: os sentidos em jogo. 2007. Dissertação (Mestrado em Ciências Sociais) - Faculdade de Filosofia e Ciências Humanas, Universidade Federal da Bahia, Salvador. 


\section{Musique baianaise?}

Representações da Bahia e do Brasil entre produtores musicais franceses

LUCIANA VASCONCELOS 


\section{INTRODUÇÃO}

A música popular brasileira é considerada, fora do Brasil, o cartão de visitas do país. Tal reconhecimento ganhou força, em termos mercadológicos, com o surgimento do termo world music, na década de 1980. Essa expressão vai designar, na Europa e nos Estados Unidos, uma categoria musical que engloba tudo aquilo que não é originário do espaço linguístico anglo-americano e/ou tudo aquilo que se apresenta como música tradicional e/ou música popular produzida nas diferentes regiões do mundo, incluindo, também, as músicas tradicionais da Europa e dos Estados Unidos. A designação world music se popularizou a partir de uma campanha de marketing organizada por selos independentes na Inglaterra, em 1987, capitaneados pelo músico inglês Peter Gabriel, fundador do selo Real World Music. (WORLD..., 2005)

Para Christopher Dunn (2007, p. 42), trata-se “de um rótulo inventado por um grupo de produtores no final dos anos 80 como estratégia mercadológica para vender música pop produzida fora do eixo Londres - Los Angeles”. O músico norte-americano David 
Byrne, criador do selo Luaka Bop, que lançou mundialmente, em 1989, o CD Beleza tropical, com gravações de artistas consagrados da MPB, revisaria, anos depois, o conceito escondido por trás do termo world music, "uma forma de relegar essa 'coisa' à esfera do exótico e, portanto, do 'bonitinho', estranho, mas seguro, porque o exótico é irrelevante”. (BYRNE apud DUNN, 2007, p. 42) Com o surgimento deste novo "rótulo", a música popular brasileira, associada no exterior à bossa nova e, por isso, abrigada na seção de jazz das lojas de discos, passou a ocupar as prateleiras dedicadas a esta nova categoria musical.

A França acompanhou a explosão da world music nos anos 8o, traduzindo a expressão para musique du monde $e^{1}$, e tornouse um dos mercados mais dinâmicos para esse tipo de produto cultural. Na Europa, é considerado um dos países pioneiros na descoberta e desenvolvimento de carreiras de artistas estrangeiros, tendo desempenhado um importante papel na produção e consumo de estilos musicais de diversas partes do mundo, principalmente a partir do trabalho dos produtores franceses junto aos artistas oriundos da África francófona.

Um estudo realizado por François Bensigor (2005), a pedido do Bureau Export de la Musique Française ${ }^{2}$, apontava que, em 2003, as músicas tradicionais e a musique du monde representavam entre $5 \%$ e $6 \%$ das vendas do mercado fonográfico francês, colocando-se à frente das vendas de música clássica (5\%) e do jazz e blues (4\%). Informa, ainda, que, apesar de não ter os instrumentos específicos para medir esta atividade, a fatia do mercado aumenta quando se trata dos espetáculos ao vivo. Segundo Bensigor, o fenômeno pode ser explicado do ponto de vista sociológico, tendo

Termo utilizado neste capítulo como equivalente a world music.

2 Escritório de Exportação da Música Francesa, instituição ligada ao governo francês responsável pela promoção da música francesa no exterior e pelos intercâmbios musicais entre os diversos países e a França. O Bureau tem uma representação no Brasil, sediada no Consulado da França em São Paulo. 
em vista a grande diversidade cultural da população francesa e os resultados de políticas públicas que visavam integrar os imigrantes no país. Outra razão apontada é que muitos artistas de diferentes origens culturais residem na França ou tem sólidas ligações profissionais com o país, o que facilita a divulgação de suas produções.

O fenômeno musique du monde incrementou a presença da música brasileira e, consequentemente, de artistas baianos na cena francesa. Além dos consagrados João Gilberto, Gilberto Gil e Caetano Veloso - detentores de um público fiel, artistas residentes na Bahia como Carlinhos Brown, Daniela Mercury e Margareth Menezes, e grupos como Ilê Aiyê, Olodum e Araketu já se apresentaram em festivais, teatros e casas de espetáculos franceses.

Apesar de este fato apontar para a potencialidade de mercado aos artistas, produtores e técnicos envolvidos com shows musicais na Bahia, a presença dos artistas residentes no estado, citados acima, não foi consolidada. Além disso, os artistas baianos emergentes continuam fora desse circuito. Podemos explicar essa ausência, em parte, por sua falta de acesso à rede de profissionais franceses envolvidos com essa categoria musical e, em parte, pela falta de apoio das instituições públicas brasileiras: os programas institucionais federais - assim como os estaduais - de apoio à exportação de música são ainda incipientes. Na Bahia, a exportação de shows vem se desenvolvendo de maneira informal, geralmente impulsionada por uma rede contatos pessoais desenvolvidos ao longo dos anos pelos artistas e produtores.

Esta constatação é fruto de minha experiência como produtora de shows musicais, principalmente em trabalhos de intercâmbio cultural, a maioria deles no âmbito franco-brasileiro, quando pude perceber o interesse e admiração que os franceses têm pela música produzida na Bahia. Porém, sempre me intrigou o fato de a atração dos franceses pela música baiana não refletir uma 
sistematização da atividade de exportação deste produto artístico para a França.

Decidi então investigar o assunto, por meio da pesquisa $\mathrm{Musi-}$ que baianaise? Um estudo do processo de compra de espetáculos musicais baianos na França ${ }^{3}$, que teve como principal objetivo inquirir, junto aos produtores e gestores culturais envolvidos com espetáculos de música estrangeira, como tais processos se davam na França em relação à música brasileira, fazendo, em um segundo momento, um recorte para a música produzida na Bahia.

Neste capítulo, apresento parte dos resultados desta pesquisa, no que tange às representações que os agentes culturais franceses elaboram da música brasileira e da música baiana, uma vez que, ao investigarmos processos de compra de espetáculos, é fundamental partirmos da imagem que o comprador faz daquele produto artístico. Foram realizadas entrevistas semiestruturadas com 14 profissionais envolvidos com a comercialização de shows de musique du monde, como agentes e produtores artísticos, diretores de festivais, diretores de programação de espaços culturais públicos e proprietários de espaços culturais privados. O critério de escolha destes profissionais foi sua atuação como contratantes ou agentes de artistas brasileiros em anos recentes. O seu nível de conhecimento sobre a música produzida no Brasil é bastante variado: vai desde especialistas em música brasileira até programadores de festivais e casas de espetáculos, com um mínimo de conhecimento sobre o assunto.

3 Dissertação de Mestrado realizada no Programa Multidisciplinar de Pós-Graduação em Cultura e Sociedade da Universidade Federal da Bahia, com orientação da Profa. Dra. Elaine Norberto, entre 2006 e 2008. 


\section{IMAGENS DO BRASIL NA FRANÇA}

Para uma compreensão de como se dão as representações da música brasileira na França atualmente, optei por abordar alguns momentos das representações sobre a cultura brasileira, em geral, construídas ao longo da história de intercâmbios entre esses dois países. Não se trata de fazer uma reconstituição histórica, e sim de ressaltar alguns pontos de interseção artístico-cultural que contribuíram para a formação das imagens da música brasileira na França.

Antes mesmo da chegada dos franceses ao novo continente, de certa forma, o Brasil já habitava o imaginário francês, que sonhava com o paraíso lendário do "novo mundo". Rabelais foi o primeiro autor francês a se referir ao Brasil. Numa passagem de La vie inestimable du grand Gargantua, père de Pantagruel ${ }^{4}$, o Senhor Nausiclète, personagem do livro, fala dos navios vindos "das Ilhas das Pérolas dos Canibais (Brasil) carregados de lingotes de ouro, seda crua e pedras preciosas”. (RABELAIS, 1534 apud CARELLI; THÉRY; ZANTMAN, 1987) É nesse livro que aparece pela primeira vez a palavra exotique.

As primeiras incursões francesas às costas brasileiras despertaram sentimentos ambivalentes, próprios de quem se depara com o Outro, o desconhecido. O medo e a repulsa misturavam-se à atração pela lenda do paraíso terrestre, existente antes do pecado original. Essas sensações foram experimentadas por Henrique II, que, em 1550, ofereceu aos habitantes de Rouen uma exibição dos vrais sauvages, encenando uma tribo de 300 índios, todos nus. Na verdade, apenas 50 deles eram originários da América; os outros eram marinheiros imitando seus gestos. Podemos dizer que este foi o primeiro "espetáculo" brasileiro apresentado na França. A 
exibição fez tanto sucesso que os "verdadeiros selvagens" foram apresentados novamente em Troyes, em 1564, e em Bordeaux, em 1565 .

Os contatos entre a França e o Brasil colonial também geraram vários relatos de viagem, como o publicado por Ferdinand Denis, na França, entre 1821 e 1822. Esse autor viveu em Salvador e sua descrição sobre a presença africana na cidade é mais uma contribuição para a construção da imagem étnica da Bahia no exterior, ao ressaltar a importância do papel da música na vida dos negros da cidade.

[...] Eu vi algumas vezes homens vergados pelo peso da servidão encontrarem uma espécie de liberdade através de seus cantos. Os escravos não fazem nada sem cantar; aqueles que carregam os fardos regulam seus passos na medida em que repetem um canto monótono e lento ao qual se juntam, às vezes, canções cujas letras são quase sempre improvisadas. (DENIS apud CARELLI; THÉRY; ZANTMAN, 1987, p. 138, tradução nossa)

Ainda na Bahia, ao observar um negro tocando um instrumento rudimentar, Denis descreve:

Todas as pessoas do bairro vêm escutar nosso músico cantando letras doces em sua língua. Pouco a pouco, ele revira os olhos com uma expressão singular. O entusiasmo mais delirante se reflete em toda sua fisionomia e, se ele continua seus cantos, ninguém pode resistir aos charmes potentes da harmonia: as pessoas se aproximam, se voltam para ele imitando seus gestos, lhe respondem com letras entrecortadas e pelo som de diversos instrumentos. Então a embriaguez atinge seu auge e não se pode exprimir o prazer, as palavras são insuficientes. Um europeu não entende muito isto tudo, nem pode mesmo adivinhar o motivo que comove extraordinariamente cinco ou seis pessoas e, entretanto, ele não é insensível a um espetáculo que nada tem de ridículo. (CARELLI; THÉRY; ZANTMAN, 1987, p.139, tradução nossa) 
Pode-se perceber que, apesar do caráter amador e cotidiano da cena descrita, o autor não hesita em considerá-la como um "espetáculo". Porém, neste caso, o estranhamento não implica o desrespeito ao Outro. Essa relação de respeito, aliada a um sentimento de indignação e de solidariedade diante do tratamento dado aos índios e negros, registrado pelo iniciador dos estudos brasileiros na França, pode ser considerada como prenúncio das ideias defendidas por um movimento de vanguarda, o Surrealismo Etnográfico, que ganharia força na França no início do século XX.

O fim da Primeira Guerra Mundial provoca uma mudança na forma com que os franceses se relacionavam com o Outro. Os artistas franceses, que passaram pelos horrores da guerra e viveram a barbárie, começaram a questionar o modelo da civilização europeia, concluindo que "[...] o mundo se tornava permanentemente surrealista”. (CLIFFORD, 2002, p.135) Os artistas da vanguarda parisiense passaram a olhar para a África (e, em menor grau, para a Oceania e a América) como uma possibilidade de novas formas de viver e crer. O Surrealismo Etnográfico considerava que as sociedades "primitivas" podiam ser usadas como fontes técnicas, cosmológicas, científicas e artísticas. Um novo olhar, inicialmente concentrado na vanguarda artística francesa, contamina Paris, fazendo com que a cidade seja tomada por espetáculos de artistas negros de todas as partes do mundo, fenômeno que recebe na França o nome de négrophilie:

Paris, 1925: a Revue Nègre faz grande sucesso em sua temporada no Théatre des Champs-Elysées, seguindo os passos da Southern Syncopated Orchestra de W. H. Wellmon. Os spirituals e o jazz arrebatam a burguesia de vanguarda, que toma de assalto os bares dos negros, vibra com os novos ritmos em busca de algo primitivo, selvagem e completamente moderno. A Paris da moda é levada pelo som pulsante dos banjos e pela sensual Josephine Baker [...]. (CLIFFORD, 2002, p.138) 
É nesta cena de efervescência da négrophilie que a França volta seus olhos mais uma vez para o Brasil. Artistas brasileiros começam a ser convidados para apresentar-se no país, como é o caso de Pixinguinha. O célebre músico brasileiro, junto com Donga e seu grupo Oito Batutas, apresentaram-se no clube Schéhérazade, em Paris, em 1922. Devido ao sucesso alcançado, a permanência do grupo, que tinha sido planejada para três semanas, acaba por estender-se por seis meses. (BASTOS, 2005)

O fenômeno originado pelo Surrealismo Etnográfico pode ser considerado uma das razões da presença de artistas brasileiros na França, como também pode ser a explicação para o desembarque de artistas franceses no Brasil, no início do século XX. O poeta suíço-francês Blaise Cendrars visita o Brasil pela primeira em 1924 e publica, logo depois, Feuilles de Route: le Formose ${ }^{5}$, livro de poemas ilustrado por Tarsila do Amaral, em que relata episódios e impressões de sua primeira viagem ao país. Seu interesse pela cultura popular brasileira transparece no livro e vai influenciar os próprios modernistas brasileiros. (VIANNA, 1995)

O compositor francês Darius Milhaud, amigo de Cendrars, foi outro artista francês que passou pelo Brasil nesta época e também sofreu influências da cultura brasileira. Secretário particular do poeta Paul Claudel, embaixador da França no Brasil, Milhaud morou no Rio de Janeiro entre 1914 e 1918. Tornou-se amigo de Villa-Lobos, que o levou para conhecer "macumbas" e choros. O músico francês encantou-se com a música carnavalesca. (VIANNA, 1995)

[...] Os ritmos desta música me intrigavam e me fascinavam. Havia nesta síncope uma imperceptível suspensão, uma respiração despreocupada, uma pausa breve que era difícil de apreender. Eu comprei, então, uma quantidade de maxixes e tangos; eu me esforçava para tocá-los com 


\begin{abstract}
suas síncopes que passavam de uma mão à outra. Meus esforços foram recompensados e eu pude enfim exprimir e analisar este "pequeno nada" tão tipicamente brasileiro. (MILHAUD apud CARELLI; THÉRY; ZANTMAN, 1987, p. 153)
\end{abstract}

De volta a seu país, Milhaud compôs várias peças sob a influência da música brasileira. Juntamente com o bailarino Nijinski e Paul Claudel, Milhaud criou o balé L'Homme et son désir, um pequeno drama ambientado na floresta brasileira. Milhaud utilizou temas brasileiros, o que gerou e ainda gera a polêmica sobre a possibilidade de esses "temas" serem, na verdade, plágios, como Le Boeuf sur le Toit (1920), inspirado em O Boi no telhado, de Zé Boiadeiro, uma das músicas que Milhaud incluiu na trilha sonora de um espetáculo de Jean Cocteau. Compôs também, já nos Estados Unidos, as três Danses de Jacaremim (1945). Os títulos Chorinho, Tanguinho e Sambinha atestam a influência que a música popular brasileira exerceu por longo tempo em sua criação.

\title{
A MÚSICA BRASILEIRA NA FRANÇA
}

Apesar de o público francês ter contato com a música brasileira, seja apresentada pelos próprios artistas brasileiros no país, seja através da sua influência em obras de artistas franceses, essa música não era distinguida de outras produzidas na América Latina, misturadas todas em um "caldeirão". Nos anos 40, Carmen Miranda, por exemplo, cantava músicas brasileiras vestida de baiana estilizada, acompanhada por tocadores de maracas cubanas, uma vez que, desde o início de sua carreira internacional, o propósito da cantora era representar os latinos de maneira geral, não apenas o Brasil, o que contribuiu para compor uma imagem unitária dos estilos musicais produzidos “do México para baixo”. 
A bossa nova foi o primeiro gênero musical a se consolidar no imaginário francês como especificamente proveniente do Brasil. Há algumas explicações para a ocorrência do fenômeno na França, sendo a primeira delas a aceitação de uma proposta inovadora de se fazer música popular integrada, de forma harmoniosa, a elementos do jazz e da música erudita. A segunda explicação, derivada da primeira, é a paixão que a bossa nova despertou nos músicos franceses, que se envolveram com ela a ponto de empreender viagens ao Brasil, realizando aqui parcerias musicais e, principalmente, difundindo não só a bossa nova, como também outros estilos musicais brasileiros para o grande público francês.

Parte do sucesso da bossa nova na França se deve às parcerias que aconteceram entre músicos franceses e brasileiros. Pierre Barouh foi um dos primeiros artistas franceses a conhecê-la e divulgála. Autor da trilha sonora do filme Um homem, Uma mulher, de Claude Lelouch, lançado em 1966, incluiu Samba saravah, uma versão do Samba da Benção (1962), de Vinícius de Moraes e Baden Powell. Segundo o próprio compositor, “[...] o Samba da Benção foi um sucesso enorme, com grande repercussão". (BAROUH apud DELFINO, 1988, p.131) Saravah é também o título de um documentário gravado por Barouh no Brasil, lançado em 1972, com cenas raras de Pixinguinha, João da Baiana, Maria Bethânia, Baden Powel e Paulinho da Viola. O músico francês fundou um selo e uma editora, também com o nome Saravah, existentes até hoje.

Georges Moustaki, músico egípcio radicado na França, conheceu a bossa nova por intermédio de Barouh e também veio a se apaixonar:

6 Lamentavelmente, a inclusão de Samba da Bênção na trilha do filme foi acompanhada de um gafe histórica: não colocaram o nome dos autores nos créditos do filme na cópia apresentada na avant-première, em Cannes (à qual estava presente Vinícius de Moraes), antes da abertura do festival. "Vinícius de Moraes nunca me perdoou”, declarou Pierre Barouh. (FRELAND, 2005) 
Pierre Barouh chegou com um disco de João Gilberto, Chega de Saudade, e eu fiquei fascinado. Não compreendia como ele conseguia colocar tudo aquilo junto, aqueles acordes, aquelas harmonias todas ao mesmo tempo. (MOUSTAKI apud DELFINO, 1988, p. 133)

A relação de Moustaki com a música brasileira, iniciada na década de 1960, dura até nossos dias. Aos 72 anos, o músico lançou, em 2006, o CD Vagabond, gravado em grande parte no Rio de Janeiro, com Francis Hime como produtor e diretor musical. $\mathrm{O}$ disco presta uma homenagem a Tom Jobim e tem uma das faixas intitulada Bahia.

A percepção de que o Brasil é um país musical, ressaltada por muitos entrevistados na pesquisa empírica, também é colocada por Georges Moustaki:

[...] o Brasil é música. Então, até quando os brasileiros buzinam, é sempre dentro de um ritmo. Quando eles batem o carro, têm ritmo. A modulação da voz deles, para lhe dizer uma frase, já é um desenho melódico. A música está na pele deles. (MOUSTAKI apud DELFINO, 1988, p. 133, tradução nossa)

A Bahia também está presente nas recordações de Moustaki na visita à casa de Vinícius de Moraes, em Salvador. O músico admira-se com uma outra forma de se relacionar com a vida, com o trabalho e com a música:

Tem uma bela imagem que eu guardo. Foi quando eu vi Vinícius de Moraes ensaiando na sua casa, na beira do mar. Eu estava na casa, muito simples, que ele tinha alugado. Cheguei, atravessei a casa e eles estavam lá na areia, fumando, tocando, bebendo, rindo. E era esse o trabalho deles. Porque é assim que vêem a música. Eles não tinham organização alguma e, entretanto, tudo se encaixava. À noite, nós íamos ao show e tudo dava certo, tudo nadava na felicidade. (MOUSTAKI apud DELFINO, 1988, p. 134, tradução nossa) 
O Tropicalismo será outro movimento musical brasileiro a ser percebido na França. A proposta tropicalista não é percebida como um movimento cultural organizado na França, mas as composições e performances de seus artistas são bem acolhidas. Quase todos os entrevistados, ao serem perguntados sobre que músicos brasileiros teriam hoje um público cativo na França, responderam que Gilberto Gil e Caetano Veloso são garantia de casa cheia.

O reconhecimento não é só do público e dos profissionais especializados. Em 1990, Gilberto Gil recebeu do Ministro da Cultura, Jack Lang, o título de Cavaleiro da Ordem das Artes e das Letras e, em 2005, já Ministro da Cultura do Brasil, as insígnias de Grand Officier da Légion D'Honneur, entregues pelo Ministro da Cultura e das Comunicações, Renaud D. Vabres. Na ocasião, o ministro francês aclamou o artista baiano, tanto por suas obras como por seu trabalho político.

O sucesso de Gilberto Gil na França e nos outros países da Europa deve-se, ainda, a uma estratégia de desenvolvimento de carreira que o cantor empreendeu ao longo dos anos. Segundo o testemunho do agente musical Jean-Michel Debie, Gil planejou a construção de sua carreira na Europa e, desde 1978, realiza regularmente turnês durante o verão europeu. Caetano Veloso também foi homenageado por uma importante instituição cultural francesa, a Cité de la Musique ${ }^{7}$, situada no Parc de La Villette, em Paris, recebendo, em 1999, carte blanche ${ }^{8}$ para programar, durante três dias, shows com convidados especiais. A imprensa francesa também está atenta ao trabalho dos dois artistas, mesmo quando as grandes gravadoras os boicotam, como no caso do

7 Estabelecimento público ligado ao Ministério da Cultura francês, que agrupa um conjunto de instituições dedicadas à música. Entre os espaços que compõem a Cité de La Musique, há uma conceituada sala de espetáculos com capacidade para mil pessoas.

8 Expressão usada quando a organização de um espetáculo permite ao artista convidar outro artista ou outros artistas para o show. 
lançamento do disco Tropicália 2 (1993), na França. Veronique Mortaigne (1994) faz uma crítica ao disco, no jornal Le Monde, ressaltando o fato:

TROPICÁLIA 2, uma das experiências musicais mais inteligentes destes últimos anos, foi lançado há um ano no Brasil. Seus autores, Gilberto Gil e Caetano Veloso, cantores mundialmente conhecidos, farão um show na França no início de julho. Mas a poderosa multinacional que produziu o álbum julgou que não seria bom lançar o disco aqui (na França), devendo suas filiais européias ignorar a existência dele. Importado a conta-gotas, encontrável em raros pontos de venda especializados, Tropicália 2 agora pode ser encontrado nas lojas da $\mathrm{FNAC}^{9}$, graças a seu serviço de importação. Devemos bradar pelo milagre ou pela infâmia?

Rémy Kolpa Kopoul, crítico musical e diretor da Radio Nova, em Paris, sempre que escreve sobre Caetano, termina os artigos com a seguinte frase, um pouco difícil de traduzir em português: "S'il ne reste qu'un au monde [...]"10 (KOPOUL, 2005, p. 201)

\section{VOZES DA FRANÇA}

Analisando os discursos dos entrevistados sobre as imagens que vêm construindo da música popular brasileira e da música produzida na Bahia, percebe-se que a alternância entre a atração e o estranhamento em relação ao outro - iniciada com as primeiras incursões francesas em terra brasileiras - que reconhece e nega, ao mesmo tempo, as diferenças culturais, persiste até hoje. As declarações de amor pelo Brasil e a fixação na ideia de música

9 Grande cadeia francesa de lojas de vendas de CDs, DVDs e aparelhos eletro-eletrônicos. Atualmente, a FNAC também vende ingressos para shows, o que pode sugerir uma opção do mercado em investir em espetáculos ao vivo face à queda das vendas de CDs.

"Se tivéssemos que escolher um, no mundo, seria ele". (tradução nossa) 
festiva, bem como as limitações impostas sobre os tipos de gêneros musicais aceitáveis como brasileiros, são exemplos de discursos que oscilam entre a admiração respeitosa e o estereótipo associado ao exotismo.

A simpatia dos franceses pelo Brasil parece ser uma das premissas básicas para entender como são construídas as diversas representações sobre a música brasileira, beneficiária deste sentimento que não é espontâneo e sim, fruto de um relacionamento desenvolvido ao longo da história. Um dos entrevistados, o agente artístico francês Frédéric Gluzman, especializado em música brasileira, não fala apenas de simpatia e sim de uma relação de amor entre o Brasil e a França:

FG: - Há um espaço para a música brasileira aqui, porque há uma história de amor entre o Brasil e a França. Esta história de amor [...] você pode ver que sempre existiu esta história, mas sempre vem em fases, temporadas. $[\ldots]^{11}$

O proprietário da casa de espetáculos parisiense Cabaret Sauvage, Mezaine Azaïche, sabe que terá garantia de casa cheia quando programa as Noites Brasileiras. Frédéric Mazzely, diretor de programação de espetáculos do Parc de la Villette em Paris, também tem certeza de que o público francês "lota o espetáculo" devido a um "amor verdadeiro dos franceses, em geral, pelas músicas brasileiras, no plural”. Olivier Delsalle, diretor do Festival Île de France, também debita à simpatia dos franceses pelo Brasil o sucesso dos shows brasileiros programados pelo festival durante o Ano do Brasil na França em 2005.

A diversidade aparece como um dos aspectos mais relevantes nas descrições da MPB. Quase todos os entrevistados iniciaram as descrições ressaltando esta qualidade, utilizando discursos, muitas vezes, idênticos entre si:

11 Depoimento concedido à autora em maio de 2008. 
Marc Régnier ${ }^{12}$ : - Não posso falar da música brasileira e sim das músicas brasileiras. Para mim, o Brasil é um caso único de riqueza de musicalidade, de criatividade [...] Então, o que simboliza para mim as músicas brasileiras é esta diversidade, é esta criatividade enorme e essa capacidade de assimilar estas influências exteriores e traduzir esta mistura de uma forma única. ${ }^{13}$

Stéphane Delangenhagen ${ }^{14}:-[\ldots]$ não podemos falar da música brasileira. Para mim, são as músicas brasileiras, as músicas do norte, do sul, as músicas ligadas ao samba, tem o rock brasileiro. ${ }^{15}$

A explicação mais frequentemente apontada pelos entrevistados para a diversidade da música do Brasil é a fusão das diferentes culturas e etnias. A mestiçagem, considerada a principal característica da brasilidade, é responsável pelo "doce amálgama” encontrado na MPB.

Ao lado da imagem de diversidade, que de certa forma representa um respiro, uma abertura para o acolhimento das diferentes produções da música brasileira, encontra-se, com a mesma frequência, a associação à festa, alegria e carnaval. $\mathrm{O}$ "espírito da festa” está colado à imagem da MPB. Essa percepção tem como base uma característica real: a presença e a vitalidade da festa nas manifestações culturais brasileiras. A questão se torna problemática quando a imagem é fixada e engessa outras possibilidades, operação que os próprios entrevistados chamaram de clichê.

Clichê e estereótipo são duas palavras derivadas da indústria gráfica que têm significados parecidos, qual seja, o de reprodução fixa, sem possibilidades de modificações. Homi Bhabha define estereótipo como um processo de representação ambivalente,

\footnotetext{
12 Agente artístico especializado em música brasileira.

13 Depoimento concedido à autora em maio de 2008.

14 DJ e Representante do selo brasileiro Biscoito Fino na França.

15 Depoimento concedido à autora em maio de 2008.
} 
apoiado no conceito de fixidez, conotando rigidez e verdades imutáveis, e, que, ao mesmo tempo, precisa ser repetido "ansiosamente" inúmeras vezes para adquirir status de verdade. A repetição em excesso acaba por produzir um efeito de "verdade probabilística" que poderia ser provada empírica ou logicamente como, por exemplo, "a licenciosidade dos negros" ou o "comportamento dissimulado do asiático”. (BHABHA, 1998)

O congelamento da ideia da música do Brasil como uma música festiva leva, por exemplo, Jean-Paul de Boutellier, o diretor do Festival Jazz à Vienne e um dos maiores festivais de jazz da França, a convidar apenas os artistas - mais restritivamente, cantores ou cantoras - de música popular brasileira, na acepção convencional de MPB, para garantir uma "noite de festa". Apesar de conhecer e admirar músicos brasileiros de jazz, Boutellier os exclui da Noite Brasileira por fazerem uma música "menos exuberante".

Além da associação à festa, alegria e carnaval, Frédéric Mazzely oferece uma pista sobre uma das motivações dos franceses para frequentar os shows brasileiros: a busca do exotismo. Segundo Mazzely, Brasil e Índia são os dois países que mais atraem o público francês, o que se deve em grande parte à dimensão exótica de que se veem revestidos.

Jean-Michel Debie confirma a atração do francês pela dimensão exótica da cultura brasileira, reproduzindo, ainda hoje, o discurso do mito do bom selvagem, criado a partir dos relatos dos primeiros viajantes descobridores do novo mundo, e que, segundo Todorov, representava, na verdade, uma crítica do europeu ao seu próprio modo de vida. (TODOROV, 1989)

Jean-Michel Debie: - Sim, certamente o francês, o europeu de maneira geral, os italianos certamente, os povos latinos, são muito atraídos pelo exotismo brasileiro e encontram sensualidade na música de carnaval, com certeza. É também uma procura inconsciente do estado do paraíso natural; nós todos temos 
a fantasia, e eu também, de estar lá em comunhão com os seres mais puros, mais virgens, mais em harmonia com o próprio corpo, com sua sexualidade, como se nós vivêssemos de uma forma mais intelectual, mais neurótica, enquanto o brasileiro vive de uma maneira mais animal ou mais instintiva. Isto também pode ser um clichê, é difícil separar o que é clichê, eu conheci brasileiros que estão muito longe deste clichê, claro, mas é a imagem geral, há sempre uma imagem que predomina. ${ }^{16}$

A descrição de Jean-Michel Debie também aponta a função de fetiche exercida pela música brasileira, ao associá-la à sensualidade. O mesmo acontece com o empresário, proprietário de casas de espetáculos em Paris, Stéphane Vatinel, que reafirma a imagem exótica associada ao Brasil - lembrando os gestos de Carmen Miranda -, sugerindo também o caráter sensual da música ao falar da forma de dançar das mulheres brasileiras. Mais uma vez, vemos claramente que a atração é pelo diferente, como podemos aferir na resposta de Frédéric Mazzely sobre os shows de Carlinhos Brown:

Frédéric Mazzely: - Acho que há uma forma de exotismo. Eu me lembro de quando Carlinhos Brown se apresentou aqui. Foi muito alegre, muito bom, as pessoas adoraram, se entusiasmaram, tinha muita gente. Acho que ele tem uma grande capacidade de manter uma relação forte com o público, tem uma presença em cena que é muito forte, mas é verdade que tem um lado de exotismo, que agrada muito ao público. É pela performance, pela apresentação, pela maneira de dançar, de se exprimir, o ritmo é muito diferente de nós. Eu acho que é isto que nos agrada. ${ }^{17}$

Tal atração pelo exótico na arte e cultura brasileira vem causando reações de artistas no Brasil há algum tempo. No início

16 Depoimento concedido à autora em maio de 2008.

17 Depoimento concedido à autora em maio de 2008. 
do Modernismo, o exotismo foi um dos temas fulcrais: os modernistas tiveram de enfrentar a difícil questão de assumir uma identidade nacional e, ao mesmo tempo, evitar cair na armadilha de fazer, como dizia Oswald de Andrade, "macumba para turista". Não se tratava apenas de uma crítica de âmbito doméstico, havia uma grande preocupação com a imagem da música do Brasil no exterior, particularmente na Europa. Mário de Andrade, em seu Ensaio sobre a Música Brasileira, publicado pela primeira vez em 1928, alertava que um dos fatores que contribuem para uma "falsificação da identidade brasileira" é a "opinião do europeu”. (ANDRADE, 1972, p.14) Para o autor, o interesse da Europa pela música nacional dizia respeito apenas à busca pelo exótico; qualquer tentativa de fazer uma música diferente do "batuque brabo" era considerada como um arremedo da música culta europeia e, portanto, indigna de apreciação.

A Europa completada e organisada num estádio de civilisação, campeia elementos estranhos pra se libertar de si mesma. [...] o que a Europa tira da gente são elementos de exposição universal: exotismo divertido. Na música, mesmo os europeus que visitam a gente perseveram nessa procura do exquisito apimentado. (ANDRADE, 1972, p. 15)

Pode-se compreender a bossa nova e o movimento tropicalista, também, como reações a esta tentativa de enquadrar a arte brasileira na categoria do exótico. Porém, como visto acima, esta operação continua a vigorar e, apesar de a pesquisa ter encontrado discursos elogiosos sobre a diversidade da música brasileira, esbarrou em uma pergunta concreta sobre que estilos não são considerados como música brasileira. Algumas respostas mostraram que a "diversidade" da música brasileira tem um limite. Apesar de reconhecerem que o rock, o jazz e o reggae são também produzidos no Brasil, encontraram-se afirmações enfáticas de que tais gêneros não são considerados música brasileira e, portanto, 
não provocam o interesse do público francês. Algumas afirmações podem surpreender os brasileiros, ou até mesmo causar uma certa vertigem, não apenas quanto às restrições em relação às produções artísticas brasileiras, mas também quanto à nossa localização no mundo. Observe-se o diálogo travado com Frédéric Mazzely:

Frédéric Mazzely: - [...] Mas, para voltar à questão em relação ao rock, intuitivamente, eu diria que, no momento, nos festivais de rock na França que vemos a torto e a direito, eu diria que é mais identificado a um estilo ocidental, americano, inglês, um pouco europeu e de fato só vai até aí. Todo o resto vai entrar no registro que é world music. Mesmo se fizéssemos um show de rock brasileiro, entraria neste gênero, acho difícil encaixar o rock brasileiro nos festivais de rock daqui.

\section{LV: Por quê?}

Frédéric Mazzely: - Porque há uma cultura, para nós ocidentais, nós nos banhamos numa cultura, depois dos anos 6o, numa cultura rock que é mais americana, inglesa, é a razão principal. E tudo que se faz em termos de criação, em termos de rock, nestes países continua ainda a dominar largamente o mercado e a ser apresentado nos festivais. Por exemplo, no próximo festival Villette Sonic deste tipo de música que eu vou fazer, $70 \%$ a $80 \%$ serão de produção americana e inglesa. ${ }^{18}$

Percebe-se que a própria noção Oriente-Ocidente é uma função cognitiva criada por um imenso complexo social que se autodenominou Ocidente. (MOURA, 2001) Alguns autores, como Edward Said e Homi Bhabha, tentarão desvelar o binômio Oriente-Ocidente mostrando como o aparato do poder colonial fixou a imagem do oriental como "um outro, mas ao mesmo tempo apreensível e visível”. (BHABHA, 1998, p.111) O que surpreende 
é que, enquanto brasileiros, nos consideramos simplesmente ocidentais ${ }^{19}$.

Porém, existem posicionamentos mais abertos em relação à questão, uma aceitação maior, desde que estes gêneros, considerados “ocidentais", tenham a "cor brasileira”. Neste sentido, o rock, a música eletrônica, o jazz e até mesmo o reggae são bem recebidos por parte dos entrevistados quando incorporam elementos identitários da música reconhecida como brasileira. Os ritmos, as melodias, os sons dos instrumentos típicos, os arranjos, a forma de tocar e de cantar considerados característicos do Brasil devem ser identificados pelo ouvinte, mesmo em se tratando de gêneros que tradicionalmente não são considerados brasileiros.

\section{MUSIQUE BAIANAISE?}

No desenvolvimento da pesquisa, ao questionar a imagem que os agentes culturais franceses cultivam da música produzida na Bahia, experimentei o receio de que esta pergunta parecesse um tanto pretensiosa. Afinal, trata-se de um estado não hegemônico em termos políticos ou econômicos de um país da América do Sul; país este não localizado, no imaginário francês, no Ocidente e tampouco no Oriente. No âmbito do mercado musical internacional, a música popular brasileira está enquadrada na categoria musique du monde, competindo com todo um continente, a África; com grupos de países, como a região dos Bálcãs e sua música cigana; com países como Cuba e Índia e ainda com regiões europeias como Catalunha e Andaluzia, para citar alguns exemplos. Desta forma, a pergunta "Como você descreveria o que chamamos de música baiana?”, mesmo endereçada a profissionais franceses

19 A questão é que, se nós não somos ocidentais, tampouco orientais somos (apesar de termos sido confundidos com a Índia, em 1500). Diante das declarações de Mazzely, cabe a pergunta clichê: quem seríamos nós, afinal? 
que trabalham no âmbito da musique du monde, pode parecer uma presunção.

Contudo, foi possível constatar que a palavra Bahia faz sentido para todos os 14 entrevistados, mesmo que alguns não tenham identificado um tipo específico de música ou possa citar um artista associado ao lugar. Para Stéphane Vatinel, esta palavra tornou-se uma expressão idiomática da "língua brasileira", por ser tantas vezes repetida nas composições. Em um estudo sobre a presença do nome da Bahia na música popular brasileira, o pesquisador Luiz Américo Lisboa Júnior, por exemplo, encontrou e transcreveu as letras de 272 sucessos em que se fala da Bahia. (LISBOA JUNIOR, 1998) O estudo engloba apenas o período entre 1904 e 1964, não alcançando o Tropicalismo e a axé music.

A maioria dos entrevistados, ao identificar a Bahia, vai associá-la diretamente à África e à influência na música baiana da cultura aportada pelos escravos. Stéphane Delangenhagen, quando pensa na Bahia, pensa em música afro-brasileira e cita Araketu, Olodum, Carlinhos Brown e a axé music como representantes. Benoit Thiebergien, diretor do Festival $38^{\text {ème }}$ Rugissants, percebe a presença da África em uma "música mestiça” e Olivier Delsalle reconhece vários elementos da cultura africana na música e na paisagem da Bahia.

A associação da Bahia à cultura africana no discurso dos entrevistados franceses confirma a tese de que o "texto da baianidade" apoia-se fortemente na etnicidade; entretanto, devemos estar atentos às observações feitas por Milton Moura: "[...] o étnico coincide normalmente com o outro, na acepção de bárbaro, estrangeiro, estranho, ou mesmo o simples diferente". (MOURA, 2001) Corremos o risco de cair novamente na simples atração pelo exótico. Entretanto, é possível individualizar discursos que vão além do exotismo, no caso, em relação à questão étnica: 
RKK: - [...] no Ano do Brasil na França, neste show que eles fizeram na Bastilha, [...] o momento mais comovente para mim foi quando o Ilê Aiyê subiu no palco e tocou com Daniela Mercury e, para mim, assistindo o Ilê Aiyê na Praça da Bastilha, na frente da coluna... O Ilê, que é um símbolo da cultura negra baiana, na Praça da Bastilha, que é um símbolo da Revolução Francesa. O símbolo foi muito forte. ${ }^{20}$

O discurso de $\mathrm{RKK}^{21}$ sobre a força da união de dois símbolos - a presença de um bloco fundado e mantido por descendentes de escravos na praça que representa, para a civilização ocidental, um símbolo da luta pela liberdade e cidadania - tem um conteúdo político que está longe de ser considerado uma imagem estereotipada.

A postura ambivalente - de um lado, um relativismo cultural com possibilidades de simetria e, de outro, a concepção de hegemonia do colonizador em relação ao colonizado - transpareceu ao longo de toda a pesquisa e, muitas vezes, na voz de um mesmo entrevistado. Marc Régnier, agente de artistas brasileiros, por exemplo, reconhece a questão étnica baiana falando do "orgulho da raça negra":

MR: - Há uma coisa que eu gosto muito na Bahia: é o orgulho das pessoas, especialmente o orgulho dos negros, a postura dos negros em Salvador me agrada muito. No Brasil, eu não vejo um racismo como que existe aqui, mas ele existe de fato. Há uma discriminação racial e social, é evidente. Tem mais negro na favela do Rio do que branco [...] O que eu gosto em Salvador é o orgulho do negro. ${ }^{22}$

20 Depoimento concedido à autora em maio de 2008.

21 É assim que Rémy Kolpa Kopoul assina seu nome, ou ainda com R2K.

22 Depoimento concedido à autora em maio de 2008. 
Entretanto, o mesmo Marc Régnier reproduz um discurso estereotipado ao descrever a imagem descontextualizada que faz das performances baianas:

- A partir do momento que vejo uns negões pintados com os tambores enormes, batucando e dançando, isto é muito [...] tem pinta de baiano. ${ }^{23}$

Junto à enfática presença da cultura africana como característica fundamental da música baiana, encontra-se novamente a associação à música de festa, de carnaval. Para alguns franceses, a música brasileira confunde-se com a música da Bahia, principalmente para os que frequentam o país e o carnaval baiano. $\mathrm{O}$ depoimento de Regina del Papa, produtora artística brasileira radicada na França, é contundente:

\begin{abstract}
RP: - [...] O DJ tocava Tim Maia, Adoniran Barbosa e havia franceses que chegavam e perguntavam: 'Quando você vai tocar música brasileira?’. Porque, para eles, música brasileira era música baiana, porque a referência é o carnaval da Bahia. Até hoje, há um público que vem nas Noites Brasileiras e vem aos shows e, quando o DJ faz a intervenção, ele pede a música baiana, porque, para esse público, a música brasileira é a música baiana. Até hoje, isso existe aqui. Há o público típico francês que vai todo ano ao Brasil, para o carnaval da Bahia, e que espera a música baiana. ${ }^{24}$
\end{abstract}

A associação da música baiana ao carnaval é corroborada por Bernard Aubert, diretor do Festival Fiesta des Suds em Marselha, um dos mais importantes festivais de musique du monde do sul da França, que convidou integrantes da associação carnavalesca Afoxé Filhos de Ghandy para participar de seu evento. Aubert também testemunha o interesse do público francês pelo carnaval baiano.

23 Depoimento concedido à autora em maio de 2008.

24 Depoimento concedido à autora em maio de 2008. 
Regina del Papa informa, ainda, que o tipo de música baiana que seu público pede, nas Noites Brasileiras que promove na França, é a axé music, e vai citar as bandas baianas de carnaval, Chiclete com Banana, Banda Eva, Cheiro de Amor e as cantoras Daniela Mercury e Ivete Sangalo como representantes de tal música.

Alguns dos especialistas em música brasileira entrevistados fazem restrições à axé music, tanto em termos de gosto pessoal quanto da possibilidade de conquistar uma posição estável no mercado de musique du monde, na França. Jean-Michel Debie considera a axé music muito efêmera, não correspondendo à qualificação que a imprensa especializada francesa faz da MPB. Stéphane Delangenhagen também desqualifica a proposta musical da axé music.

Indagado sobre os artistas baianos, o jornalista RKKé capaz de fazer uma lista deles, incluindo os blocos afro-baianos, e conclui que este variado mosaico garante uma "forte especificidade" à música produzida na Bahia ou por artistas baianos. RKK ressalta, também, a falta de novas propostas musicais baianas:

RKK: - É verdade que temos artistas únicos na Bahia, que eu já disse agora: Dorival Caymmi, João Gilberto, Caetano Veloso, Gilberto Gil, Tom Zé, Bethânia, Gal, Margareth, Daniela Mercury, Carlinhos Brown, os blocos afros, sim, tem uma especificidade muito forte e tem figuras fortíssimas. Mas, em termos de música baiana hoje em dia, por exemplo, eu acho que tem... Se não tivesse estes artistas que ficam sempre na frente... Bom, Carlinhos Brown e Daniela já são quarentões. Margareth Meneses já tem quase... E depois, o que tem? Eu diria que não chegou nada de novo. ${ }^{25}$

Dentre os artistas baianos, Caetano Veloso e Gilberto Gil foram os mais citados pelos entrevistados. Carlinhos Brown e Daniela Mercury são outros artistas associados à Bahia. Ronan 
Corlay, diretor de uma empresa de eventos francesa que produziu o grande show da Praça da Bastilha nas comemorações do Ano do Brasil na França, ressalta a força cênica dos dois últimos e sua capacidade de interagir com o público. Ao fazer referência ao trio elétrico, Corlay está imputando a esta invenção baiana - que leva o palco para desfilar pela cidade, aproximando o artista das multidões - a peculiaridade das performances, que encantam o público francês.

RC: - Os grandes artistas baianos, sobretudo. Eu, que trabalhei com a produção deles aqui na França, acho que, sobretudo, eles têm uma verdadeira tradição de show. Quando falamos de Carlinhos Brown e Daniela Mercury são bêtes de scène [feras de palco], sei que os artistas brasileiros, em geral, têm uma relação muito específica com a cena, mas se me lembrar de um momento do show na Bastilha em 2005, o momento em que as pessoas mais se empolgaram foi com Daniela Mercury, que não era a mais conhecida. Carlinhos Brown é a mesma coisa. Quando o vemos em seu trio elétrico, é uma verdadeira performance de ritmo, de dança, de jogo com o público, que é muito interessante. ${ }^{26}$

Carlinhos Brown alcançou um grande sucesso na vizinha Espanha, onde lota estádios e arrasta multidões quando passa com seu trio elétrico. Percebe-se que o artista é considerado como “objeto de desejo" por alguns diretores de festivais e agentes artísticos franceses, como Bernard Aubert e Frédéric Gluzman. O fetiche se justifica pela promessa de apresentações impactantes, garantia de sucesso de público.

Como se pode observar na fala de RKK, quase nada de novo da música produzida na Bahia tem chegado à França. Quando se indagou aos profissionais que tipo de informação eles têm recebido sobre a produção recente musical da Bahia, a resposta foi unânime: 
nenhuma ou pouquíssima tem chegado à França, nem da parte dos próprios artistas e produtores, nem via instituições públicas. Os entrevistados surpreendem-se com a ausência de novas propostas musicais baianas na cena francesa.

Os programadores franceses percebem a demanda de novidades por parte do público. Não se trata, necessariamente, de novas formas musicais, ou da aparição de novos talentos. Muitas vezes, pode ser a apresentação de artistas e tipos de músicas desconhecidas do público francês, como no caso da iniciativa tomada por Stéphane Delangenhagen, que programou uma "noite baiana" com Riachão ${ }^{27}$ e a banda de percussão Didá ${ }^{28}$, no conceituado auditório da Cité de la Musique, em Paris, com capacidade para mil pessoas, durante o Ano do Brasil na França. A escolha causou estranhamento até a um representante da mídia baiana:

SD: $-[\ldots]$ Na época, eu fui entrevistado por uma pessoa da Bahia que queria saber por que eu tinha escolhido Riachão e a banda Didá e por que não Ivete Sangalo, ou uma outra grande estrela, uma vez que Riachão não é conhecido. Ninguém entendeu a escolha da programação; eu expliquei que minha escolha era por artistas completamente novos, eu estava visando pessoas que já conheciam um pouco da música brasileira e queria mostrar outras coisas da música da Bahia e, depois, esta música tem uma tradição e não é pop. Então, achei que estes grupos se enquadravam no que eu queria, eram grupos de percussão e um grupo de samba, eu não queria programar o mais conhecido, eu queria um grupo que o público francês não estava habituado a ver. Eu queria um grupo de percussão e sabia da Didá, sabia do trabalho de Neguinho do Samba. ${ }^{29}$

27 Riachão, tradicional sambista baiano, nascido em 1921, é o autor de sucessos como Cada macaco no seu galho e A nega não quer nada.

28 A banda de percussão Didá é composta apenas por mulheres e foi criada pelo percussionista Neguinho do Samba em Salvador, em 1993.

Depoimento concedido à autora em maio de 2008. 
Concluo o capítulo com a fala de Stéphane Delangenhagen que expressa a potencialidade do Desejo de encontro entre as duas culturas, que ainda não esgotaram o mútuo processo de conhecimento. O produtor francês relata a dificuldade encontrada e sua persistência em promover, na França, o show de Riachão - um dos patrimônios mais caros da música baiana que, por diversas razões conjunturais, não fez carreira no exterior.

SD: - Eu me lembro muito bem de Riachão, eu telefonei, a mulher dele atendeu. Foi difícil encontrá-lo. Pesquisei através de publicações, através da Internet, de nome de agentes e, finalmente, encontrei um agente que me deu o telefone de Riachão. Telefonei para a casa dele e sua mulher atendeu ao telefone. Eu disse que estava falando de Paris e que queria convidar Riachão para um show na França. Ele estava consertando alguma coisa no telhado e ela gritou 'Riachão! Riachão! É a França!' $3^{30}$ 


\section{REFERÊNCIAS}

ANDRADE, Mário. Ensaio sobre a música brasileira, 3ed. São Paulo: Martins Editora, 1972.

ASSOCIATION POUR LA DIFFUSION DE LA PENSÉE FRANÇAISE (APDP). France Brésil. Paris: Ministère des Affaires Étrangères, 2005.

BASTOS, Rafael José de Menezes. Les Batutas, 1922: uma antropologia da noite parisiense. Revista Brasileira de Ciências Sociais, São Paulo, v. 20, n. 58, 2005.

BENSIGOR, François. Le Marché des Musiques Traditionnelles et du Monde en FranceInventaire 2004 en Perspective Européenne. Disponível em: <www.irma.asso.fr/spip.php?article3306>. Acesso em: 7 jun. 2007.

BHABHA, Homi K. O local da cultura. Belo Horizonte: Ed. UFMG, 1998.

BRASIL, Ministério das Relações Exteriores. Ano do Brasil na França. Brasília: Ministério das Relações Exteriores, 2005.

CARELLI, Mario; THÉRY, Hervé; ZANTMAN, Alain. France-Brésil: bilan pour une relance. Paris: Éditions Entente, 1987.

CLIFFORD, James. A experiência etnográfica: antropologia e literatura no século XX. Rio de Janeiro: Editora UFRJ, 2002.

DELFINO, Jean-Paul. Brasil Bossa Nova. Aix-en-Provence: Édisud, 1988.

DUNN, Christopher. Gringos amantes do Brasil: como a tropicália ganhou o mundo, na visão de um estudioso americano. Bravo!, São Paulo, n. 120, p. 42-43, ago. 2007.

FRELAND, François-Xavier. Sarava. Paris: Naïve, 2005.

KOPOUL, Rémy Kolpa. O Brasil em cem discos: uma seleção, do patrimônio ao futurista. In: RIAUDEL, Michel. France Brésil. Paris: Association pour la diffusion de la pensée française (ADPF) CULTURESFRANCE, 2005, p. 197-215.

LISBOA JUNIOR, Luiz Américo. A presença da Bahia na música popular brasileira. Brasília: Musimed, 1998.

MORTAIGNE, Veronique. Tropicalia 2, de Gilberto Gil e Caetano Veloso - Bahia, désordre et douceurs. Le Monde, Paris, jun. 1994. 
Disponível em: http://www.lemonde.fr/cgibin/ACHATS/acheter. cgi?offre=ARCHIVES\& type_item=ART_ARCH_3oJ\&objet_ $\mathrm{id}=329919>$. Acesso em: 25 mar. 2008.

MOURA, Milton. Carnaval e baianidade: arestas e curvas na construção de identidades do carnaval de Salvador. 2001. Tese (Doutorado em Comunicação e Cultura Contemporâneas) - Faculdade de Comunicação, Universidade Federal da Bahia, Salvador.

TODOROV, T. Nous et lês autres - la réflexion française sur la diversité humaine. Paris: Éditions du Seuil, 1989.

VIANNA, Hermano. O mistério do samba. Rio de janeiro: Zahar/ UFRJ, 1995.

WORLD music: one-world fantasy or marketing tactics?.

Music : A Global Phenomenon, n. 1, 2005. Disponível em: < http://webcache.googleusercontent.com/search?hl=ptBR\&q=cache:okYXV9vqhUwJ:http://mondialogo2.bluemars.de/ fileadmin/download/pdf/mag/mondialogo_magazine_en_o1. pdf+WORLD+music\%3A+\%22one-world+fantasy\%22+or+marketing +tactics\%3F.\&ct=clnk>. Acesso em: 5 fev. 2011. 


\section{Axé music}

mitos, gestão e world music

ARMANDO ALEXANDRE CASTRO 


\section{INTRODUÇÃO}

No filme El Milagro de Candeal, o diretor Fernando Trueba, centrando sua argumentação em essencializações acerca da musicalidade, da cultura e religiosidade da Bahia, apresenta o encontro do pianista cubano Bebo Valdez e Carlinhos Brown. Já nas primeiras cenas, Bebo Valdez confidencia ao músico, compositor e pesquisador baiano Mateus Aleluia (Grupo Tincoãs, Cachoeira, Bahia), o conselho que lhe deu, em 1947, uma ialorixá - também cubana -, caso prosseguisse em sua investigação musical e antropológica motivada por questionamentos identitários: conhecer a cidade de Salvador, Bahia.

À beira-mar, o diálogo entre os músicos é precedido de inúmeras outras cenas que apontam indícios e entrelaces dos aspectos religiosos, culturais e musicais baianos inscritos ao longo do tempo e história, como que atendendo às expectativas de parcela considerável de estrangeiros e suas imagens/impressões de uma Bahia mítica e paradisíaca. A película segue. Do simpático taxista, ele recebe uma sonora e entusiasmada acolhida: que fosse bem-vindo 
à Bahia, terra da felicidade. Em seguida, surge a estátua de Vinícius de Moraes em Itapuã. Após o desembarque no Pelourinho, a ida a uma das igrejas, onde presencia um ensaio musical de Mateus Aleluia e integrantes do grupo musical cachoeirano Gêge Nagô. Na cena seguinte, eis que surgem Carlinhos Brown e o Grupo Zárabe, numa espécie de aquecimento pelas ruas e becos do Candeal Pequeno, como num ensaio a céu aberto do que aconteceria mais adiante na apresentação e aparição destes numa das festas mais tradicionais de Salvador: a de Yemanjá.

As imagens apresentam alguns elementos emblemáticos da marca Bahia no mundo globalizado: música, protagonismo e performance artística, criatividade, diversidade, em que tradição e modernidade dialogam, não raro, sem maiores incidentes na visão do diretor. Por outro lado, revela as estratégicas arquiteturas de veiculação e associação de elementos simbólicos a marcas territoriais distintivas, a partir da seleção de elementos que redimensionam a imagem de uma Bahia marcadamente étnica, exótica e espontânea, tal como apontaram viajantes, brasilianistas e naturalistas que por estas terras se aventuraram em outros tempos.

Das surpresas e entusiasmo dos primeiros viajantes estrangeiros, passando pelas cantigas de capoeira e requebros da portuguesa/brasileira/hollywoodiana Carmem Miranda e chegando aos refrões pop da axé music, a Bahia (re)afirma sua inscrição e presença em parte considerável do cenário cultural internacional. $\mathrm{Na} \mathrm{MPB}$, sua presença é central, podendo ser percebida enquanto temática e inscrição vultosa de artistas e autores que a ela se reportaram. Numa perspectiva histórica, cantaram, compuseram e corroboraram com tal participação nomes como Tia Ciata, Donga, Xisto Bahia, Dorival Caymmi, Assis Valente, Carmem Miranda, Ary Barroso, João Gilberto, Vinícius de Moraes, Caetano Veloso, Gilberto Gil, Gal Costa, Tom Zé, Raul Seixas, Moraes Moreira, Maria Betânia e Roberto Mendes, entre outros. 
Desta fonte diversa e multicultural, vê-se o surgimento de uma Bahia plural em sua produção musical contemporânea, com trânsito entre o samba-chula do Recôncavo ao rock and roll, de onde ainda se faz ouvir, nas inúmeras cenas musicais soteropolitanas, o grito Viva Raul! Bahia do século XXI, naturalmente plural e plugada em links e wireless, consensos, conflitos, timbaus e guitarras.

Entretanto, é aí que se percebe o maior desafio da produção musical baiana contemporânea, sendo que poucos olhares midiáticos têm conseguido perceber tal diversidade. Não raro, a escassa visibilidade midiática desses diversos fazeres musicais locais e suas complexas redes de pertencimento e conectividade têm dado lugar ao desconhecimento ou à disseminação de discursos e textos que omitem - alguns casos - e/ou distorcem as cenas musicais soteropolitanas. Isto reitera a necessidade de não somente produzir canções, grupos e elaborações estéticas, mas executá-las e publicizá-las diante de um maior número possível de pessoas, tal como afirma Nando Reis na obra Itaim para o Candeal - faixa que encerra Timbalada - primeiro disco do grupo homônimo, lançado em 1993: "Gosto de tocar no rádio, o que parece óbvio é fundamental”. (CONCEIÇÃO, 1993)

Neste sentido, serão evidenciadas neste capítulo outras possibilidades de compreensão da axé music, tendo como prerrogativas centrais a díade estética e mercado. $O$ gênero baiano massivo enquanto produção, fruição e apreciação estética, como também sua relevante participação e interação com as tramas mercadológicas e organizacionais alinhadas à indústria fonográfica e musical. Mais uma vez, da Bahia para o mundo, música. Desta vez, com articulação empresarial.

Assim, apresenta-se aqui a produção musical baiana contemporânea denominada axé music, aportando elementos na tentativa de desconstrução de três mitos construídos em torno 
de si: monocultura, baixa qualidade técnica e decadência. A metodologia utilizada privilegia a análise de conteúdo, tendo como meios de verificação e coleta de dados a pesquisa de campo, com aplicação de entrevistas semiestruturadas com músicos, técnicos, produtores e empresários musicais de Salvador, além de pesquisa documental.

\section{BREVE HISTÓRIA DA AXÉ MUSIC}

A breve história aqui apresentada se faz pela necessidade de contextualização, não se configurando como objeto central de análise, e procura evidenciar a década de 1980, enquanto temporalidade de legitimação dos chamados blocos de trio no carnaval soteropolitano - ampliando consideravelmente o alcance comercial e mercadológico deste -, fato que possibilitou o surgimento de novos grupos e bandas musicais.

Miguez (2002) sinaliza que os primeiros blocos de trio no Carnaval de Salvador surgem na primeira metade da década de 1970, a partir da iniciativa de jovens de classe média alta. A expressão remete à substituição das atrações musicais tradicionais, tipo charangas e orquestras carnavalescas, pelo trio-elétrico enquanto palco móvel para apresentação de bandas e artistas locais emergentes.

Estimulada e contratada por empresários destes blocos carnavalescos e seguindo parâmetros estético-musicais apontados pelos Novos Baianos, Dodô e Osmar, Moraes Moreira, Pepeu Gomes, Armandinho e a religiosidade e força percussiva apontada por blocos afro como Filhos de Gandhi, Muzenza, Badauê, Ilê Aiyê e Olodum, iniciou-se a formação de um relevante conjunto de novos artistas e estrelas de trio em Salvador, tais como Luiz Caldas, Sarajane, Ademar e Banda Furtacor, Virgílio, Jota Morbeck, Djalma 
Oliveira, Lui Muritiba, Daniela Mercury, Zé Paulo, Marcionílio e Banda Pinel, entre outros.

A estética musical herdada pela axé music é composta por diversos estilos e gêneros musicais locais e globais, como o frevo, o ijexá, o samba, o reggae, a salsa, o rock e lambada. Percussão e guitarras - baianas, preferencialmente - temperavam o "caldeirão" de uma cidade que reverbera música e etnicidade. (MOURA, 2001, p. 221) Moura (2001) conceitua axé music a partir desta pluralidade em sua gênese, como não sendo um gênero musical, mas "interface de estilos e repertórios".

Trataremos dessa questão adiante, mas cabe salientar que, em meio a essa diversidade, observavam-se duas predominâncias no carnaval soteropolitano até a primeira metade da década de 1980: Dodô e Osmar no quesito trio-elétrico e o frevo enquanto gênero musical massivo. É Luiz Caldas quem desloca consideravelmente estas referências, inscrevendo não somente o trio-elétrico Tapajós, mas o ijexá nas rádios comerciais da cidade. O Tapajós - propriedade de Orlando Tapajós - é palco, inclusive, da banda Acordes Verdes, que tinha Luiz Caldas como seu cantor e idealizador.

Em 1985, Luiz Caldas lança o LP Magia, registro comercial de um artista que logo alcançaria as paradas de sucesso de boa parte do Brasil com a faixa Fricote (Nêga do cabelo duro). Tendo como autores o próprio Luiz Caldas e Paulinho Camafeu, Fricote representava uma musicalidade baiana de entretenimento. A ampla receptividade da obra e da estampa deste artista com visual exótico reforçava as dinâmicas musicais já existentes em Salvador, tais como a musicalidade e a territorialidade dos blocos-afro relevantes enquanto referência estética para autores, artistas e sociedade.

A intensa presença midiática de Luiz Caldas no cenário musical e sua associação, à época, com o jovem e promissor Bloco Camaleão; a ascensão dos blocos-afro espalhados pela cidade; o 
interesse e incursão das gravadoras no campo artístico local; o apoio de empresários e radialistas também locais - com destaque para o proprietário de estúdio Wesley Rangel e o radialista Cristóvão Rodrigues, respectivamente; e o início de uma aliança entre artistas e forças políticas são apenas alguns elementos e indícios que se somavam, à época, com a situação privilegiada da Bahia no campo cultural e artístico nacional.

O novo cenário musical baiano, de meados da década de 1980, necessitava de nome, paternidade e referências para registro. Convencionou-se, então, a partir de inscrições e iniciativas jornalísticas: Luiz Caldas, o pai; o LP Magia e a música Fricote, marcos iniciais. Vamos a eles: a expressão axé music é reforçada coletivamente a partir de textos e críticas do jornalista Hagamenon Brito, que procurava negativar tal produção musical. Na relação inicial de seus primeiros artistas e a imprensa, a diminuta compreensão acerca do estilo contemplava a sua dependência com relação ao setor fonográfico nacional, e quase sempre orientava para a suposta ausência de criatividade e baixa qualidade técnica de seus músicos e intérpretes.

A correlação de forças midiáticas e musicais procurou, sem sucesso, ofuscar que a nomenclatura axé music, para além dos preconceitos e estereótipos, continha a possibilidade de fusão, do encontro entre estéticas e instrumentos musicais distintos: axé representava o afro, o tribal, o negro, o candomblé; music contemplava o pop, a world music, neste caso, estilizado pelo encontro de guitarra e timbau, além da mediação pela voz em refrões fáceis e repetitivos.

No que concerne à necessidade de instituir paternidade e referências, há controvérsias. Luiz Caldas, o álbum Magia e a obra Fricote não necessariamente têm que ser considerados marcos iniciais, mas indícios relevantes na historiografia da axé music, enquanto suas primeiras referências mercadológicas. Deve-se 
considerar o caráter processual deste fenômeno, tal como Norbert Elias (1995, p. 234) sugere: “[...] nada mais inútil quando lidamos com processos sociais de longa duração do que a tentativa de determinar um começo absoluto”. Artistas atuais, à época, já se apresentavam e lançavam discos antes mesmo de Luiz Caldas - o Chiclete com Banana, por exemplo, lançou em 1983 dois discos: Traz os Montes e Estação das Cores.

O fato mais marcante é que, em 1986, o álbum Magia atinge a marca de 120 mil cópias vendidas. A exposição midiática e musical de Luiz Caldas, à época, representava novas possibilidades para a indústria fonográfica nacional, que prontamente se voltaria para a mais nova produção musical soteropolitana. É neste contexto que surge e se substancializa no cotidiano da cidade, e mais tarde do Brasil, a composição Faraó, de autoria de Luciano Gomes, elencando o Olodum e seus ensaios no Pelourinho como vitrine de composições e compositores emergentes. Nestes ensaios, artistas e autores apresentavam e experimentavam suas músicas, em busca de legitimação popular. A ocorrência de tal aceitação representava alcançar outras etapas da produção musical que desembocaria em profissionais como Wesley Rangel e Cristóvão Rodrigues.

Neste relato, vale o registro de que o Olodum, mediante a pronta aceitação popular de suas obras, cantores e de seu ensaio na famosa "Terça da Benção", passou a promover duas modalidades deste: aberto e fechado. $\mathrm{O}$ "ensaio aberto" era realizado nas noites de domingo, no Largo do Pelourinho; o "fechado", nas noites de terça-feira, na quadra do Teatro Miguel Santana, sendo necessária a aquisição comercial de ingressos.

Neguinho do Samba, percussionista experiente e responsável pelos arranjos percussivos da banda Olodum, apresentava boa parte de suas "experimentações" sonoras, fundindo o samba-duro baiano e o reggae jamaicano, chegando às células rítmicas do samba-reggae - base rítmica predominante e característica da axé music. 
Neste sentido, Gilroy (1993) reflete acerca da modernidade a partir das culturas do Atlântico Negro, caracterizada pelo seu aspecto híbrido, e não restrito a etnicidade e nacionalismo. A partir desse autor, pode-se também problematizar a axé music, bem como alguns elementos de sua gênese - por exemplo, o fenômeno disseminador dos blocos afro soteropolitanos. Parte considerável de artistas da axé music procurou se desvencilhar desta temática, enquanto outros a tomaram como central em seu repertório.

Lima (2002) enriquece esta discussão a partir de três exemplos soteropolitanos emblemáticos - Ilê Aiyê, Olodum e Timbalada -, afirmando existir entre estes trajetórias discursivas distintas envolvendo música e etnicidade. A ampla atuação nacional e internacional do Grupo Cultural Olodum realçou e impulsionou sua dinamicidade e complexidade organizacional, dialogando tradição e modernidade a partir de ideais vinculados à etnicidade e, em especial, aos dilemas e dramas do afrodescendente baiano e brasileiro, como observou Dantas (1994).

Acerca da percussão enquanto elemento da axé music, ainda hoje se pode perceber sua predominância nos blocos afro, blocos de trio, artistas e bandas responsáveis pela música dos blocos de corda, ainda que alguns blocos afro tenham aventurado associar experiências percussivas a instrumentos harmônicos e melódicos. Um dos principais precursores desta transformação, o bloco Ara Ketu, chegou a ser criticado por se distanciar dos seus elementos e objetivos iniciais, como num processo acentuado de descaracterização. (GUERREIRO, 2000)

As transformações não estavam restritas ao universo da axé music, mas à própria cidade... A década de 1980 não apresentou somente o início da aparição midiática e estruturação empresarial do gênero em questão, mas o início de um conjunto de transformações socioeconômicas e culturais no Estado, tais como os primeiros 
anos de atividade do Complexo Petroquímico de Camaçari; da disseminação de shoppings centers; do maior complexo de comunicação do estado (Rede Bahia); da aparição e fortalecimento de grandes organismos empresariais carnavalescos, chamados blocos de trio (Miguez, 2002); do surgimento dos blocos afro e ampliação de suas atividades, contando inclusive com registros fonográficos; de encontros musicais inusitados até então, como o Concerto da Orquestra Sinfônica da Bahia com o Afoxé Filhos de Gandhi, fruto de provocações e reivindicações de artistas e compositores baianos; de Carlinhos Brown e seu Vai quem Vem, grupo que se desdobraria posteriormente, em sua perspectiva musical e multiétnica intitulada Timbalada.

Moura (2001) sinaliza parte destas transformações enquanto modernização da cidade de Salvador, sendo inclusive motivo e tema para outras formas de visibilidade e inscrição no/do carnaval soteropolitano, assinalando a força relacional deste enquanto experiência social comunitária que se estende aos novos modelos de convivência urbana contemporânea. Para Miguez (2002), a década de 1980, então, configura-se enquanto consolidação do mercado de bens simbólico-culturais no Brasil, iniciado nas duas décadas anteriores; no caso Bahia, duas dinâmicas se consolidam, prioritariamente, na formatação e legitimação da axé music: os blocos afro (estética e temáticas) e os blocos de trio (mercado).

Na década de 1990, é este mercado que ativa seus mecanismos, personagens e teias midiáticas e eleva a axé music e seus principais interlocutores ao topo das paradas musicais nacionais, reposicionando no tabuleiro competitivo da indústria fonográfica o gênero sertanejo. Aliando a percussividade dos blocos afro aos acordes e harmonias de bandas e artistas como Luiz Caldas, Sarajane, Banda Reflexu's, Daniela Mercury, Banda Eva, Banda Beijo (Netinho), Chiclete com Banana e Asa de Águia, entre outros, consolidou-se na agenda dos programas televisivos e radiofônicos 
associados ao mercado fonográfico nacional, sendo alvo dos interesses das gravadoras majors em atividade no país.

O repentino sucesso comercial e midiático da axé music também oportunizou comportamentos isomórficos no mercado, além de inúmeros registros negativos. Um deles, a proliferação de considerável contingente de bandas, intérpretes e empresários que não privilegiaram o lado artístico de suas produções, deixando na história fonográfica deste gênero álbuns e gravações de questionável qualidade.

Numa outra perspectiva, sua extensão efetiva aos dias atuais encontra-se diretamente relacionada ao próprio desenvolvimento do carnaval soteropolitano e suas múltiplas atividades interrelacionadas. Dentre elas, destaque para os blocos de cordas e o conjunto de organizações empresariais advindos das estrelas e artistas deste segmento musical, motivando discussões e embates ideológicos acerca de elementos presentes e constituintes de aspectos circunscritos a tradição e modernidade.

Entretanto, ainda hoje, não raro, a constante presença e legitimação da axé music no cenário musical local e nacional é marcada por dissensões e mitos - estes compreendidos aqui enquanto ideias não correspondentes à verificabilidade do fato social. Dentre os mitos, neste trabalho, destaque para o da monocultura, da suposta baixa qualidade técnica e de sua tão propagada crise/ decadência/desaparecimento.

\section{MITO I - MONOCULTURA DA AXÉ MUSIC}

A compreensão de que a produção musical baiana atual é restrita à axé music é equivocada (Quadro I) e, não raro, amparada no desconhecimento da diversidade presente no campo musical baiano. Ora silenciosa, ora invocando os meios de comunicação, 
parte considerável da diversa produção musical baiana é exportada diariamente, seja virtualmente, seja nas remanescentes lojas tradicionais de CDs e DVDs, seja ainda nos inúmeros shows e participações de artistas baianos que se apresentam fora e dentro da Bahia.

Composta por inúmeros artistas esteticamente vinculados ao mundo do rock, reggae, forró, samba, samba junino, pagode, partido alto, MPB, salsa/merengue, jazz, erudito e pop, a Bahia dialoga sua textualidade e inscrição no competitivo campo das marcas, a partir da relação tradição e modernidade. É bem verdade que, dentre inúmeros gêneros e estilos musicais, é a axé music o maior exemplo de estruturação e organização empresarial, mas não o único. Monocultura significa unicidade e ausência de outros discursos e elementos estéticos, não sendo este o caso da axé music. A Bahia, em especial Salvador, congrega produção e fruição de inúmeros gêneros musicais.

\begin{tabular}{|l|l|l|}
\hline Bairro & Espaço/Casa de Show & Gêneros Musicais \\
\hline Rio Vermelho & $\begin{array}{l}\text { Boomerangue } \\
\text { Casa da Mãe } \\
\text { Tom do Sabor } \\
\text { Espaço Jequitibar/Varanda do } \\
\text { SESI } \\
\text { Borracharia } \\
\text { All Music Bar } \\
\text { The Twist Pub } \\
\text { Paralela }\end{array}$ & $\begin{array}{l}\text { MPB, Salsa, Forró, } \\
\text { Pop, Rock, Reggae, } \\
\text { Eletrônico, outros. }\end{array}$ \\
$\begin{array}{l}\text { Wet'n Wild } \\
\text { Parque de Exposições }\end{array}$ & $\begin{array}{l}\text { Axé music, Pagode, } \\
\text { Sertanejo, Salsa, Forró, } \\
\text { Pop, Rock, Reggae, } \\
\text { Eletrônico, Gospel, } \\
\text { outros. } \\
\text { Comércio }\end{array}$ & $\begin{array}{l}\text { Axé music, Pop Rock, } \\
\text { MPB. }\end{array}$ \\
\hline
\end{tabular}




\begin{tabular}{|c|c|c|}
\hline Orla & $\begin{array}{l}\text { Mamagaya } \\
\text { Beach Beer } \\
\text { Oba Oba Music Hall }\end{array}$ & $\begin{array}{l}\text { Pagode, Axé music, } \\
\text { outros. }\end{array}$ \\
\hline $\begin{array}{l}\text { Avenida } \\
\text { Contorno }\end{array}$ & $\begin{array}{l}\text { Bahia Marina } \\
\text { Cais Dourado }\end{array}$ & $\begin{array}{l}\text { Axé music, Pop Rock, } \\
\text { MPB. }\end{array}$ \\
\hline Ribeira & Marina da Penha & Pagode e Arrocha. \\
\hline Barris & Beco de Rosália & MPB. \\
\hline Pituba & $\begin{array}{l}\text { What's Up } \\
\text { Rock It } \\
\text { Pra Começar } \\
\text { Hit Music Bar } \\
\text { Trindade Music bar }\end{array}$ & $\begin{array}{l}\text { Pop Rock, Forró, Axé } \\
\text { music, Funk, e Reggae. }\end{array}$ \\
\hline Barra & $\begin{array}{l}\text { Club Lotus } \\
\text { Bohemia } \\
\text { Groove Bar }\end{array}$ & $\begin{array}{l}\text { Eletrônico, Forró, Pop } \\
\text { Rock, Axé music. }\end{array}$ \\
\hline $\begin{array}{l}\text { Jardim dos } \\
\text { Namorados }\end{array}$ & Madrre & $\begin{array}{l}\text { Forró, Axé music, } \\
\text { Pop, Funk, Pagode, } \\
\text { Eletrônico, MPB. }\end{array}$ \\
\hline Boca do Rio & Empório & $\begin{array}{l}\text { Forró, Pagode e Axé } \\
\text { music. }\end{array}$ \\
\hline Garibaldi & Estação Ed Dez & $\begin{array}{l}\text { Pagode, Forró, Axé } \\
\text { music, Pop Rock e } \\
\text { Gospel. }\end{array}$ \\
\hline \multirow[t]{2}{*}{$\begin{array}{l}\text { Campo } \\
\text { Grande } \\
\text { Itaigara }\end{array}$} & Concha Acústica do TCA & $\begin{array}{l}\text { MPB, Reggae, Axé. } \\
\text { music, Forró, Rock, } \\
\text { outros. }\end{array}$ \\
\hline & $\begin{array}{l}\text { Parque da Cidade } \\
\text { B-23 Lounge Music Bar }\end{array}$ & $\begin{array}{l}\text { MPB, Reggae, Rock, } \\
\text { Forró, outros. }\end{array}$ \\
\hline
\end{tabular}

Quadro I - Bares, Boates e Casas de Shows/Eventos em Salvador Fonte: Pesquisa de campo do autor realizada entre os meses de novembro e março/2010.

Os elementos simbólicos podem conferir à Bahia sentidos do pop massivo e carismático, em cujo âmbito os registros do percussionista do Olodum erguendo o instrumento com as cores 
da Jamaica já não mais lhe pertencem... Configura-se enquanto arquivo sempre disponível a downloads, evidenciando e disseminando a marca de um estado com produção musical diversificada que, não raro, agrega e agrada, fixa e desloca constantemente sentidos identitários, (re)orientando olhares, sensações, experiências e as próprias (re)significações identitárias. (HALL, 1999; CANCLINI, 2003)

A axé music, assim como os demais gêneros musicais produzidos na Bahia contemporânea, constitui-se enquanto marca distintiva e agregadora de significantes, relações físicas/metafísicas e potencialidades, tal como qualquer outro gênero musical. Para Silva (2003), as significações sociais são estruturantes, constituindo utilidade e tessituras identitárias diversas que favorecem consumo e distinção. Não obstante, a autora aprofunda as discussões acerca da criação, utilização e funcionalidade das marcas na contemporaneidade, identificando, distinguindo, localizando, enquadrando e incorporando sentidos diversos em seu processo de afirmação, sendo a marca um campo simbólico que se alimenta do real (o histórico de seus produtos e obras) e do imaginário (o histórico construído através da comunicação). Ou seja, as estratégias corporativas pertencentes à gestão de marcas englobam bens tangíveis e intangíveis que se complementam e se (re)significam socialmente.

Esta relação - consumo e lógica social - também é analisada por Bourdieu (1989) em considerações acerca da distinção social e da sociedade de consumo. Sahlins amplia esta discussão evocando conceitos estruturantes do capitalismo industrial e pós-industrial, em que pessoas e objetos estariam "[...] unidos em um sistema de avaliações simbólicas, sendo o próprio capitalismo um processo simbólico". (SAHLINS, 2003, p. 209) Por sua vez, Castoriadis (2000, p.142), ao descrever as ordens racionais existentes nos 
campos simbólicos específicos, adota a expressão "universo significativo" para tal assunto.

Neste sentido, a lógica social do consumo enquanto elemento distintivo e detentor de significações sociais e sentidos pode ser incorporada ao configurar a axé music enquanto marca impulsionadora de novas lógicas e atores sociais. Elias (1995, p.) advoga que a condição humana é desejosa de diferenciação e status, a partir de regras socialmente instituídas e legitimadas de valores e hierarquizações distintivas mediante o consumo. Tais valores “[...] são sempre determinados também pela nossa esperança de ver que os outros têm consciência do nosso mérito, ou pelo aumento do nosso prestígio pessoal”. (ELIAS, 1995, p. 50-51)

Compreendendo o campo simbólico como a territorialidade mediada pelos signos e símbolos, enquanto elementos "por excelência da integração social" que possibilitam o consenso acerca do sentido do social (BOURDIEU, 1989), o próprio sentido de contemporâneo é constantemente ressignificado mediante as transformações econômicas, tecnológicas e sociais também constantes. Não obstante, a espetacularização (DEBORD, 1997) é um dos sinais contemporâneos mais incisivos, e, sendo assim, a produção musical baiana contemporânea aqui apresentada se locupleta desta estrutura que mundializa cultura(s), atribuindo novos sentidos à contemporaneidade, ao espetáculo.

Sendo assim, a axé music, enquanto produção simbólica, contribui para a inscrição do produto Bahia mundo afora, como é comum em outras territorialidades que articulam elementos e feixes constitutivos de seu patrimônio cultural como estratégia de atratividade e mercantilização de produtos turísticos formatados, dinâmicos e globalizados. Para Ianni (1999, p. 124), a obtenção de renda mediante negociação do seu espaço, das suas culturas e produções simbólicas, além de provocar deslocamentos, integra-se ao contemporâneo, sendo que: 
Em todas as esferas da vida social, compreendendo as empresas transnacionais e as organizações multilaterais, os meios de comunicação de massa e as igrejas, as bolsas de valores e os festivais de música popular, as corridas automobilísticas, as guerras, tudo se tecnifica, organiza-se eletronicamente, adquire as características do espetáculo produzido com base nas redes eletrônicas, informáticas, automáticas, instantâneas e universais.

Eis, então, que a telemática e as convergências em redes eletrônicas realçam o poder do simbólico contemporâneo, contribuindo para configurar o âmbito das políticas neoliberais. Nesta lógica, no campo baiano, são inúmeras as iniciativas governamentais não somente relacionadas à axé music, como também a outros estilos. No bojo das atividades desenvolvidas pela extinta Secretaria de Cultura e Turismo do Governo do Estado da Bahia, até 2006, projetos como o Emergentes da Madrugada, Bahia Singular e Plural e Sons da Bahia permitiram o registro fonográfico de boa parte desta diversidade cultural do Estado.

Mais uma vez, no caso Bahia, a visibilidade ressalta apoios de agências governamentais aos seus artistas, uma vez que, não raro, dada a força midiática e massiva de seus repertórios e incursões, estrelam campanhas publicitárias estratégicas que destacam as potencialidades culturais e naturais do estado para seus principais centros emissivos de turistas. Trata-se da música e da etnicidade como elementos simbólico-culturais e fatores motivacionais de deslocamento turístico.

O simbólico, neste caso, produz reconhecimento, afetividade, representatividade - política, inclusive - e ignora o arbitrário, o desacreditado e o ilegítimo. Ainda assim, compreendendo desta forma o campo simbólico, não se pode excluir as outras forças e poderes nele inscritas, dentre esses, a produção artística e as relações e conflitos daí advindos. Um deles é a competitividade - a guerra fiscal é apenas um caso - entre os próprios estados brasileiros, 
tendo como suporte, de um lado, as suas produções artísticas e culturais, e do outro, a força dos meios de comunicação aí instalados enquanto atores relevantes nas tramas da Indústria Cultural. Moura (1996, p.7), no caso da Bahia, observa que descartar ou não procurar evidenciar suas potencialidades seria equívoco:

O produtor, o mercador e a mercadoria são um mesmo todo, contraditório e desigual. Em descartando a participação desse todo na sua diversidade, que significa inclusive potencialidades ainda não cogitadas e exploradas, estaríamos arriscando um capital humano fantástico, o que poderia adquirir cores sombrias em tempos de vacas tão magras.

Em outras palavras, envolve outras possibilidades de benefícios não restritos ao Carnaval nas suas dimensões de dinâmica e temporalidade. Enquanto dinâmica, a axé music se substancializa em artistas/empresários locais consagrados nacionalmente, suscitando novas atividades, necessidades, profissionais, consensos e conflitos... Já enquanto temporalidade, a axé music extrapola o circuito do carnaval soteropolitano, numa extensa programação de shows e micaretas que se inter-relacionam com o carnaval de Salvador, numa espécie de retroalimentação não restrita às sonoridades, mas às corporações locais - produtoras, agenciadores, editores musicais, etc.

O mercado do entretenimento, da indústria cultural centrada especialmente em Salvador e seu Recôncavo, de certa forma se nutre dos alinhaves identitários, tanto no sentido dos arcabouços sociológicos quanto naquele dos temas econômicos. Poder-se-ia perguntar, então: que Bahia é esta, capaz de competir com transnacionais da indústria fonográfica, por exemplo, tensionando a relação a partir de uma produção musical e fruição estética próprias? Novos e velhos vetores de sentido (SILVA, 2003) 
se inscrevem e são estimulados junto ao imaginário nacional e internacional acerca do locus e ethos Bahia.

Por outro lado, houve críticas à participação estratégica do órgão estadual de turismo - a BAHIATURSA - nos últimos anos, quando de seu apoio a alguns artistas da axé music em shows por outros países, tendo como contrapartida a divulgação da marca Bahia e de suas ferramentas publicitárias, tais como portais eletrônicos de divulgação turística. O fato é que a mesma Bahiatursa também proporcionou uma viagem internacional do grupo Zambiapunga, caso singular de manifestação cultural tradicional do meio popular do Baixo Sul Baiano, entre outras iniciativas governamentais de apoio e fomento às produções artísticas e culturais.

O mito da monocultura pode estar atrelado à força política, econômica e empresarial dos principais artistas deste gênero baiano. Na esfera política, articularam-se relações, benefícios e interesses com governantes e meios de comunicação. O carnaval soteropolitano vem passando por complexas modificações de modo a atender interesses dos gestores culturais vinculados à iniciativa privada, no campo musical. O tradicional encontro de trios da Praça Castro Alves não mais existe e o tradicional circuito do Campo Grande apresenta sinais de decadência, despertando cada vez menos interesse dos artistas de maior peso empresarial.

A concentração econômica dos principais artistas da axé music no carnaval soteropolitano é considerável. Bandas e artistas como Ivete Sangalo, Asa de Águia, Daniela Mercury e Chiclete com Banana, individualmente, são representantes empresariais de inúmeros blocos e camarotes.

Passando ao campo simbólico, axé music pressupõe diversidade, e dela se (retro)alimenta. É comum seus artistas experimentarem em seus repertórios composições inteiras, fragmentos, colagens ou combinações entre gêneros presentes na produção musical baiana. Nada extraordinário até então, uma vez que a po- 
lissemia conceitual das experimentações e encontros dos gêneros musicais é inerente ao próprio conceito de gênero, numa perspectiva de que as fronteiras estéticas do gênero musical enquanto apropriação e categoria são tênues, distintivas e subjetivas.

Nesta direção, a confluência das formas rítmicas e melódicas de uma musicalidade das ruas de Salvador, Recôncavo e demais regiões se interfacia com elementos da cultura mundial pop, multiétnica, multicultural e world music, representando a própria “interface de estilos” sugerida por Moura (2001, p. 220). Para Guerreiro (2000), a centralidade da produção musical baiana contemporânea assentada na percussividade é que garante sua inscrição ao universo da world music, em que funcionam mais facilmente as fusões entre células rítmicas, entre timbres sonoros, performances, corporalidades e novos sentidos de pertença.

As origens da axé music são distintas e, quase numa rítmica antropofágica/tropicalista, o estilo consegue unir, fundir células rítmicas e melodias, popularizando e entretendo sem maiores reflexões ou preocupações - fato que acentua seu caráter massivo e de entretenimento. Ainda segundo Moura (2001, p. 221):

Vejo aí, também, o próprio ecletismo dos elementos que passam a se encontrar nesse intrigante repertório que tantas páginas tem merecido de jornalistas, críticos, comunicólogos e cientistas sociais. A axé music apresentase como texto identitário difuso e aparentemente aproblemático e consensual, referindo-se à Bahia como um todo, já desde o início contando com a participação de músicos de várias origens e estilos.

Passando ao campo organizacional, boa parte dos artistas da axé music se articulou, empreendendo suas próprias empresas relacionadas à gestão cultural - administração das carreiras artísticas e atividades a estas relacionadas, tais como selos fonográficos, editoras musicais, agências de publicidade, estúdios de gravação e produtoras de shows e eventos, entre outras. Pode-se perceber 
a preponderância, no campo do empresariado da música, dos artistas relacionados ao universo axé music, sendo que boa parte dos seus artistas é proprietária de editoras musicais.

Isto se conecta a um outro fato: a Bahia vem se configurando como o terceiro estado em número de editoras musicais no país (revistas Sucesso CD, Show Business e Relatório ECAD/UBC-20o8) e sexto em arrecadação pública, inscrevendo alguns de seus autores na liderança de rankings nacionais e regionais no quesito recebimento de direitos autorais - categoria Execução Pública.

No campo da edição musical soteropolitana, boa parte das editoras musicais é de propriedade dos artistas locais vinculados à axé music, sejam intérpretes, sejam autores, aproximando-se do quadro do eixo Rio de Janeiro/São Paulo, onde tais organizações - líderes deste mercado - estão divididas entre aquelas de propriedade das majors - corporações fonográficas nacionais e transnacionais, vide Sony/BMG, Warner Chappell, Universal Music, Som Livre e EMI - e dos artistas locais. Em Salvador, esta atividade é mais um dos desdobramentos evidenciados a partir da profissionalização do Carnaval Baiano e da legitimação da axé music.

A versão, comum em alguns meios jornalísticos, de uma monocultura da axé music em Salvador não procede. Apresenta, entretanto, evidências do reconhecimento de sua profissionalização, associadas ainda a objetivos definidos e articulação social entre os atores, fortalecendo o campo. DiMaggio e Powell (1983) afirmam que o campo organizacional só pode ser considerado se houver legitimação empírica e com definições institucionais. Para tal, os autores afirmam que são necessários quatro elementos:

a. um aumento na amplitude da interação entre as organizações no campo;

b. o surgimento de estruturas de dominação e padrões de coalizões interorganizacionais claramente definidos; 
c. um aumento na carga de informação com a qual as organizações dentro de um campo devem lidar;

d. o desenvolvimento de uma conscientização mútua entre os participantes de um grupo de organizações de que estão envolvidos em um negócio comum. (DIMAGGIO; POWELL,1983, p. 148)

Em 1999, visando a um maior grau de profissionalismo, solução de problemas coletivos do setor e ampliação dos destinos e públicos da axé music, surge a Associação dos Produtores de Axé para o Desenvolvimento da Música da Bahia - APABahia, comumente chamada de APA.

O surgimento e desenvolvimento da axé music e de organismos coletivos como a APA Bahia, tanto nos aspectos estéticos quanto organizacionais, remete, em boa parte, à profissionalização e dinamismo da produção artística e musical no Estado da Bahia. Entre as atividades da APA, encontram-se o monitoramento da execução de seus repertórios em localidades estratégicas, assim como a própria empresarização de horários nas emissoras comerciais de outros estados, visando a exposição e execução musical dos seus associados. Além disto, atua no campo político, tendo representação no Cluster de Cultura e Entretenimento do Estado da Bahia.

J.R., ex-produtor da banda Rapazzolla, discorrendo sobre a diversidade musical soteropolitana e organização empresarial da axé music, comenta:

- O Axé é a grande referência musical atual da Bahia, mas sabemos que existem outros ritmos acontecendo na cidade. Viajamos toda semana, mas, em Salvador, freqüentamos eventos de outros gêneros, e sempre divulgamos isso nas entrevistas. [...] A produção de uma banda de axé music é muito organizada. Mais até que o pagode, 
por exemplo. Posso falar porque trabalhei como produtor de pagode por dez anos. ${ }^{1}$

Com efeito, a partir de iniciativas de artistas e da própria sociedade civil, Salvador vem apresentando inúmeros eventos relacionados a outras musicalidades. Tanto quanto a axé music, o rock é merecedor de destaque frente à sua estética e organização. Dedicação, profissionalismo e amor ao rock fizeram surgir na cena soteropolitana a Associação Cultural Clube do Rock da Bahia (ACCRBA), em 1991. Esta associação sem fins lucrativos atua incisivamente na produção e organização de eventos culturais, prestação de serviços em forma de cooperativa, captação de convênios e assessoria junto às bandas de rock. Pioneira dentre as associações de rock no Brasil, são de sua responsabilidade ações que se solidificam na realização do Primeiro Festival de Rock do Carnaval no Brasil (1994), bem como do Primeiro Dia Municipal do Rock do Brasil - 28 de junho, em homenagem a Raul Seixas através da Lei 5404/98.

A ACCRBA caracteriza-se, ainda, pela articulação e intransigência quando o assunto é desrespeito ao rock no estado, assim como, quando se trata de reivindicar maiores espaços para este segmento. Possui site, rádio/podcast, comunidade virtual de relacionamento, MSN, fotolog, vídeos no Youtube, grupos de discussão na rede, entre outros. Dentre suas realizações, pode-se destacar o Palco do Rock - realizado na praia de Piatã durante o Carnaval de Salvador, com frequência superior a oito mil pessoas por ano.

A receptividade do reggae e do forró na Bahia despertou o surgimento de eventos específicos e inúmeras bandas destes gêneros com relevante diversidade. Bandas e artistas com repertórios que transitam entre o tradicional reggae - raiz, ou reggae roots - aos 
mais híbridos, com destaque para Edson Gomes, Diamba, Adão Negro, Massai, Palmares e Mosiah, entre outros.

O forró também soube consolidar seu cast de artistas e agenda de contratantes. Dentre as bandas baianas, destaque para Estakazero, Colher de Pau, Adelmário Coelho, Flor Serena, Bando Virado no Mói de Coentro, A Volante do Sargento Bezerra, Cangaia de Jegue, Sobe Poeira, Acarajé com Camarão e Tio Barnabé. São exemplos de como outros estilos musicais se estruturaram, estética e mercadologicamente, em paralelo à axé music, e se fazem presentes na mídia.

\section{MITO II - BAIXA QUALIDADE TÉCNICA}

O segundo grande mito relacionado à axé music é estabelecido a partir de sua suposta "baixa qualidade técnica". Mas o que caracterizaria e fundamentaria esta expressão? Arranjos mal elaborados? Canções repetitivas? Músicos tecnicamente pouco habilitados? Excesso de unidade temática composicional? A observação cuidadosa do campo permite afirmar que este tipo de crítica está bem próximo do senso comum de um jornalismo descuidado e superficial, eivado de desconhecimento e preconceito.

A sensibilidade e qualidade técnica dos músicos, arranjadores e diretores musicais em atividade nas bandas de axé music são relevantes no processo de sua legitimação, ainda que tais informações sejam restritas ao meio musical. Assim, como em qualquer outro estilo musical popular massivo, o virtuosismo não é regra fundante para alcance do sucesso, necessitando, ainda, de elementos outros - rede de relacionamentos, carisma, oportunismo, sorte, inteligência, habilidade e senso estético.

Na axé music, autodidatas e doutores atuam intensamente numa rotina nacional e por vezes internacional de ensaios, shows, 
viagens, gravações, estúdios, etc. O ecletismo na formação destes profissionais corresponde à diversidade constitutiva da axé music, potencializando, inclusive, oportunidades. Músicos vinculados ao universo axé não raro também acumulam experiências profissionais em outros estilos musicais, tais como o choro, jazz, samba, rock, funk, forró, eletrônico, entre outros.

O rock, por exemplo, estabelece diálogo constante com a axé music, proporcionando informações relevantes a bandas e/ou intérpretes como Asa de Águia, Netinho, Ivete Sangalo e Jammil e uma Noites. Estas influências são percebidas nos arranjos, fraseados e timbres, bem como na agressividade de alguns efeitos, distorções e riffs de guitarra. O guitarrista sergipano Adail Scarpelini, diretor musical da Voa Dois, banda revelação do Carnaval de Salvador 2008, informa que o centro da produção musical para Sergipe era - e para muitos, segundo ele, ainda é - a Bahia.

- Por muito tempo toquei e dirigi musicalmente bandas e CDs de forró. Calcinha Preta (SE), Caviar com Rapadura (CE), Colher de Pau (BA), mas sempre quis ter a experiência da axé music, da união entre percussão e harmonia. Toquei com Netinho e agora estou com a Voa Dois, além de sempre estar produzindo e gravando com outros artistas. Quando as bandas de axé iam a Aracajú, a gente ia aos shows, procurava conversar com os músicos, lia os encartes. A Bahia era nossa maior referência musical. ${ }^{2}$

Em 2008, o Prêmio Multishow de Música Brasileira agraciou um destes renomados músicos, Radamés Venâncio, na categoria Melhor Instrumentista, enquanto Ivete Sangalo, representante de uma vertente acentuadamente pop da axé music, foi agraciada nas categorias de Melhor Cantora e Melhor DVD (Multishow ao Vivo - Ivete Sangalo no Maracanã). 
Detentor de inúmeros prêmios nacionais e internacionais, Carlinhos Brown consegue aproveitar essas situações para discursar sobre uma Bahia sempre planetária e referencial na música nacional, exaltando a capacidade de diálogo estético da produção musical baiana contemporânea. Sua concepção musical não dispensa os ensinamentos e provocações herdadas de músicos contemporâneos - baianos ou radicados na Bahia - como Ernest Widmer, Walter Smétak e Lindemberg Cardoso, assim como, numa escala internacional, negocia espaços mediante novos encontros musicais. De sua parceria com o DJ Dero, em 2004, resulta o disco com forte influência eletrônica Candyall Beat, que tem como principal hit a faixa Mariacaipirinha. Lançados inicialmente na Espanha, disco e obra alcançam sucesso, remetendo, nesse mesmo ano, Carlinhos Brown - naquelas plagas conhecido por Carlito Marron - à condição de convidado musical do Fórum Universal das Culturas realizado em Barcelona.

A partir da parceria com Sérgio Mendes, em 1985, conseguiu emplacar cinco composições no álbum Brasileiro - ganhador do Grammy de melhor disco de world music. Em Salvador, naquele mesmo ano, recebe também o Troféu Caymmi. Inúmeros outros prêmios viriam nos anos seguintes, coroando Brown como um dos maiores nomes da axé music, como músico, produtor ou compositor.

A preocupação com a qualidade profissional dos músicos acompanhantes também se percebe no momento da formação das bandas. José Raimundo, tecladista, arranjador e diretor musical que acompanhou Netinho de 1989 a 1998, declara:

- Jomar entrou no grupo em 1996... A decisão de termos dois tecladistas foi uma sugestão minha, pois usávamos muito sequencer [programação], e sempre quis muito ter outro tecladista tocando comigo, por conta dos muitos detalhes de teclados que minhas duas únicas mãos não conseguiam executar. O primeiro tecladista que tocou 
com a gente foi Glauton Campelo, um excelente pianista jazzista carioca que morou oito anos nos Estados Unidos e tocava com Djavan ao lado de Paulo Calazans. ${ }^{3}$

Arranjos neste sentido corroboram a lógica de identificação e diferenciação do artista, e são inúmeros os exemplos de arranjos que se tornaram referências, remetendo diretamente músico/ arranjador a artista e vice-versa.

A estética musical da axé music encontra-se nos referenciais de timbragem e sonoridade contidos nos arranjos, mas também a partir do entrosamento musical das bandas e artistas que souberam aliar a força da sonoridade percussiva à variedade de timbres e recursos tecnológicos contidas na organologia ocidental tradicional, como guitarra, bateria, contrabaixo, saxofone, etc. Em outras palavras, o encanto se dá pela magia e carisma do artista, bem como seu entrosamento com seus pares e repertórios selecionados e previamente testados nas dezenas de shows e micaretas realizadas durante o ano, dentro e fora do Brasil.

Entrosamento, carisma, bom desempenho técnico, flexibilidade e sensibilidade são elementos referenciais nas justificativas de obtenção do sucesso por parte dos artistas e bandas de axé music. As musicalidades desta são frutos do encontro entre músicos formados nos conservatórios e faculdades, nas igrejas e terreiros de candomblé, na generosidade presente nos conselhos informais e, principalmente, nas dinâmicas experimentadas nas ruas da cidade que se pretende mundial a partir de seus fazeres e saberes artísticos, em especial, a música. 


\section{MITO III - FIM DA AXÉ MUSIC}

A relação arte/espaço, nesta discussão, a partir da percepção da produção musical baiana contemporânea no plano nacional, evidencia uma territorialidade resoluta em suas convicções de afirmação artística perante o outro - nacional ou estrangeiro; local ou global.

A especulação, neste sentido, acerca da decadência ou fim da axé music é antiga, podendo ser melhor percebida a partir do início do século XXI, e os maiores argumentos encontram-se centrados no declínio de vendas dos produtos fonográficos, bem como na escassez e ausência de renovação de seus quadros artísticos. Os principais advogados desta acusação parecem ignorar que a crise é do setor fonográfico mundial - mais acentuadamente, do formato $\mathrm{CD}$-, irrompendo-se em inúmeras fusões e desaparecimentos de gravadoras transnacionais, além da migração dos artistas para as plataformas de música online. Ora, uma crise do setor fonográfico mundial não poderia deixar de repercutir na produção musical baiana contemporânea, promovendo quebras de contrato e desligamentos de artistas dos casts das gravadoras. Isto veio impulsionar o surgimento e fortalecimento da produção fonográfica local, com inúmeros selos, editoras, produtores e distribuidores de menor porte.

As agendas de shows, as estratégias de diferenciação e inscrição estética e mercadológica, são elementos relevantes e não podem ser desconsiderados em tais reflexões. Não obstante, inúmeros artistas e bandas musicais vêm sendo incorporados ao complexo da axé music, o que demonstra sua capacidade de renovação estética junto às suas células matrizes, advindas do sambareggae e do frevo elétrico, enquanto marca e território simbólico em processo afirmação, expansão e internacionalização. 
A axé music rompeu fronteiras e barreiras mercadológicas e territoriais. Por outro lado, impulsionou o surgimento de setores e atividades que estimulam o desenvolvimento da música no Estado, além de disseminar a marca Bahia nos diversos mercados mundo afora. Nos campos estéticos ou organizacionais, inovou, criando novos mercados e possibilidades de experiências. Novas redes de profissionalidade foram e continuam sendo implementadas na Bahia, assim como a tessitura de uma ampla teia de relações a partir da legitimação deste gênero em outras localidades.

Por outro lado, a axé music dinamizou o surgimento e desenvolvimento de carnavais extemporâneos pelo Brasil - mais conhecidos como micaretas -, o mercado de trios elétricos e carros de apoio, a promoção de eventos, a produção fonográfica e outros itens da tecnologia aplicada à musica, entre outros.

A axé music está presente em eventos relevantes no showbusiness musical contemporâneo, sejam nacionais, sejam internacionais, comprovando sua vertente pop repleta de influências e informações. Em eventos como o Axé Brasil (Belo Horizonte) - exclusivo do gênero -, Brazilian Day, Festival de Montreux e Rock in Rio, a axé music conquista espaços. Nas edições 2008 do Rock in Rio Lisboa e Madrid, artistas como Carlinhos Brown e Ivete Sangalo foram recebidos por um público que, em sua maioria, conhecia e cantava seus principais sucessos.

Dentre as primeiras iniciativas de internacionalização do gênero baiano, está a Copa do Mundo de 1990, na Itália, como assinala o tecladista José Raimundo:

- Fomos para Copa do Mundo, na Itália, em 1990. Foi uma grande estratégia comercial da Perdigão, que levou o trio elétrico para Torino. Foi o primeiro trio elétrico que chegou na Europa de navio e montado. Na época em que estivemos na Itália, a lambada estava no auge por lá com o grupo Kaoma. De música brasileira eles só conheciam 
Caetano, Gil, Benjor, Djavan etc. Enfim, MPB. O axé era conhecido por uma minoria de italianos que freqüentavam o carnaval da Bahia. Quando começamos a tocar, ninguém dançava, pois eles têm uma cultura de assistir ao espetáculo e nunca tinham visto um caminhão com um som daquele tamanho. Há um ponto interessante nisso, pois tinha gente lá de todas as culturas, era uma Copa do Mundo. Eles começaram a ficar fascinados com o ritmo da música e, meio desajeitados, imitaram muitos brasileiros que estavam lá dançando e começaram a entrar no clima de festa que o axé proporciona. ${ }^{4}$

Desde a segunda metade da década de 1990, os responsáveis pelo Festival de Montreux, Suíça, agendam apresentações de artistas baianos da axé music, na esteira do processo de expansão e internacionalização da carreira de seus artistas, entre os quais Margareth Menezes, Olodum, Araketu e Ilê Aiyê.

Também o Brazilian Day, tendo a Rede Globo como uma de suas maiores empresas articuladoras, reserva a participação de artistas da axé music como protagonistas. A atuação da maior empresa de comunicação e entretenimento da América Latina junto à axé music tem sido crescente nos últimos anos, principalmente a partir da parceria com a Rede Bahia - organização e registro de boa parte dos shows no Festival de Verão, cabendo à Rede Globo a divulgação e distribuição comercial através de sua gravadora, a Som Livre.

Outro vetor relevante na expansão dos mercados da axé music é o próprio Carnaval soteropolitano. A despeito das recentes controvérsias acerca de seus custos e acentuação de seu viés comercial, esse Carnaval, ao se profissionalizar e internacionalizar, reforça e termina por disseminar, a reboque, o leque de musicalidades e artistas presentes no evento. A lista internacional de convidados famosos é extensa. Para citar os anos de 2007 e 2008: a banda 
irlandesa U2, o produtor musical Quincy Jones, Naomi Campbell, Arto Lindsay e tantos outros que ou não foram captados pelas câmeras ou preferiram o anonimato, acenando para a possibilidade de maior publicização em nível internacional de uma dinâmica centrada na axé music, embora não restrita a esse estilo.

Não obstante, a presença de celebridades nacionais também alimenta este processo, pois revela a extensa programação de shows, lavagens, festas populares, feijoadas e ensaios, reforçando, em grande medida, o mito da nuclearidade exclusivamente festiva do território baiano e sua gente. Esta lógica de retroalimentação das marcas - axé music e Carnaval -, como num feedback, também é apontada por Dantas (2005, p. 20), quando afirma a disposição da nova geração de artistas da música baiana no sentido de ampliar suas fronteiras profissionais, contribuindo para o processo de legitimação e ampliação do receptivo turístico no carnaval:

O carnaval baiano dobrou de tamanho nos anos 90: de um para dois milhões de foliões por dia participando da festa. Isso se deveu a políticas públicas de atração de turistas? Não. Ainda que, efetivamente, as políticas públicas tenham sido fundamentais para viabilizar infra-estrutura, equipamentos e capacitação de pessoal para receber turistas, o que duplicou a presença desses turistas foi a música baiana. Foi Daniela Mercury, que se tornou a maior vendedora de discos do Brasil no início da década de 1990, levando todo o país a se apaixonar pelo samba reggae "O canto da Cidade"; foi o Olodum, que levou a um patamar de prestígio internacional essa sonoridade rítmica, que conquistou ícones do pop internacional, como Paul Simon e Michael Jackson; foi o Chiclete com Banana, a Banda Cheiro de Amor, a Banda Eva, que ajudaram a "nacionalizar" o carnaval baiano.

A etnicidade é elemento pujante neste processo; não somente os blocos afro são seus representantes, mas artistas como Daniela Mercury, Margareth Menezes, Timbalada, Motumbá, Ara Ketu, 
entre outros, se apropriam mais incisivamente de seus discursos, símbolos e temáticas musicais.

O empresário Paulo Roberto, ex-proprietário da Aky Discos, até 2001 a maior rede de lojas de discos da Bahia, confirma o interesse dos turistas brasileiros e estrangeiros pela axé music:

- Uma espécie de encanto... Os gringos e turistas nacionais chegavam na loja procurando por Olodum, Daniela Mercury, Chiclete com Banana, e quem mais da axé music a gente oferecesse eles compravam. O fornecimento de CDs do Olodum para as lojas do Centro Histórico, por exemplo, tinha de ser semanal. Era de 300, 400 unidades para as maiores lojas e volumes menores para as lojas pequenas, toda semana. ${ }^{5}$

Outro aspecto relevante na argumentação contrária ao fim da axé music é a cobertura midiática internacional do Carnaval de Salvador, que registra números ascendentes de profissionais cadastrados; vários mercados em continentes distintos já manifestam interesse num dos maiores eventos de rua do mundo e sua musicalidade maior. Não raro, seus artistas excursionam por diversos países, configurando-se Espanha e Portugal como líderes neste receptivo.

Sua inscrição no mercado de bens simbólicos também contempla registros de não aceitação, aversão e restrição de sua execução pública, inclusive em termos de legislação, como nos casos dos carnavais de Recife e Olinda, que proibiram artistas e repertórios vinculados ao gênero com argumentos que contemplam o respeito e valorização aos costumes locais. A medida visa a salvaguardar laços identitários com o frevo, seja musical, seja coreograficamente, enquanto dinâmicas culturais. Contudo, não se pode argumentar que Pernambuco não contribua para a disseminação e legitimação da axé music pelo Brasil, ao contrário. $\mathrm{O}$ 
Recifolia, carnaval fora de época, encontra nos artistas baianos, seus trios elétricos, performances, refrões e repertórios, os moldes do carnaval soteropolitano.

Exemplo de êxito duradouro no campo da axé music, e, naturalmente ambientada em apresentações nacionais e internacionais, a Chiclete com Banana recebeu o Prêmio Press Award 2007, na categoria de Show Brasileiro, pelo seu destaque nos EUA. Em julho de 2008, apresentou-se nas cidades de Roma, Milão, Porto e Lisboa, em eventos de grande porte e com ingressos esgotados antecipadamente. Os artistas do Chiclete são também empresários e estrategistas, com um histórico de diálogo com obras de antigos e novos compositores. Dentre eles, e em épocas distintas, destaque para Val Macambira, Carlinhos Brown e, mais recentemente, a dupla Alexandre Peixe e Beto Garrido têm fornecido à banda inúmeros canções que são "experimentadas" em micaretas e shows antes do registro fonográfico. Em paralelo, passam a integrar rapidamente o acervo de sites e programas que distribuem arquivos de música peer to peer, vide Youtube, $e$-mule, entre outros.

Ainda que não se constitua em referência em técnica e virtuosismo musical, a banda estruturou sua carreira calcada no entrosamento do grupo, no carisma de seu líder e na escolha de um repertório sempre atualizado com o seu público. A capacidade de performance, diálogo e construção de repertório, neste sentido, apresenta a Chiclete com Banana como das mais relevantes bandas da axé music, em se tratando de regularidade na produção fonográfica, inclusive.

Em contrapartida ao fato de, historicamente, não ter apresentado altos índices de vendas no quesito fonográfico como Ivete Sangalo, Netinho e Banda Eva, por exemplo, a banda mantém uma sequência regular de registros que atende seu público mais fiel, apelidado de Nação Chicleteira, Chicleteiro, Maluquetes do Chiclete, etc. 
Artista e defensora da axé music em suas inúmeras entrevistas, Ivete Sangalo pode ser considerada a protagonista de maior sucesso mercadológico do gênero. Mesclando elementos da música pop internacional, como efeitos de guitarra e teclados, à percussividade local, também se apresenta como relevante empresária articulada entre shows, publicidade, prêmios, discos de ouro, platina, platina duplo, platina triplo, e sua presença na mídia televisiva é certeza de audiência para uma artista que já supera a marca de oito milhões de unidades fonográficas comercializadas. (ASSOCIAÇÃO BRASILEIRA DE PRODUTORES DE DISCO, 2008)

\section{A AXÉ MUSIC E A PRODUÇÃO MUSICAL SOTEROPOLITANA}

A música, enquanto manifestação cultural e artística e agente estético, no último século, consolidou-se de forma diretamente ligada ao desenvolvimento da indústria do entretenimento e show business. Até a invenção do fonógrafo por Thomas Edison, em 1877, o processo de edição musical consistia no ato de acompanhar e/ou produzir a impressão e a comercialização de partituras, que funcionava como fonte de renda e divulgação para o artista/ compositor. Atualmente, editar música extrapola o comércio de música impressa em papel, alcançando o envolvimento com a administração de relações estratégicas e concorrenciais, das novas tecnologias, poder, inovação, conflitos de interesses, profissionalização e autonomização, entre outros.

No mercado musical, editoras musicais são empresas formalmente constituídas junto ao Ministério da Fazenda e têm como objetivo principal a gestão das obras musicais de determinados compositores (pessoa física). Ora, nem todo artista musical em atividade na Bahia possui relação com produtoras, editores e 
agenciadores de shows; entretanto, parcela considerável deste segmento profissional não somente estabelece tal relação como empreende suas próprias empresas ligadas ao meio artístico, fortalecendo o mercado e a economia local, além de implementar uma nova categoria profissional no Estado: o editor musical.

\begin{tabular}{|c|c|c|}
\hline $\begin{array}{l}\text { Artista/Autor/ } \\
\text { Empresa }\end{array}$ & Produtora & Editora \\
\hline Carlinhos Brown & Janela do Mundo & Candyall Music \\
\hline Daniela Mercury & Canto da Cidade & Páginas do Mar \\
\hline Asa de Águia & Duma & Duma \\
\hline Ivete Sangalo & Caco de Telha & Caco Discos e Edições \\
\hline Vários & Tag & Tag \\
\hline Cláudia Leitte & Pedaço do Céu & Pedaço do Céu \\
\hline Mano Góes & Carreira Solo & Malu Edições \\
\hline Jammil & Carreira Solo & Таo \\
\hline Banda Eva & Grupo EVA & Pedra Velha Edições \\
\hline $\begin{array}{l}\text { Cheiro de Amor/ } \\
\text { Pimenta Nativa/Bafafá/ } \\
\text { Chica Fé }\end{array}$ & Cheiro de Amor & $\begin{array}{l}\text { Oxalá Edições } \\
\text { SW3 Edições }\end{array}$ \\
\hline Harmonia do Samba & $\begin{array}{l}\text { Harmonia } \\
\text { Produções }\end{array}$ & Muralha Edições \\
\hline $\begin{array}{l}\text { Oz Bambaz/Laduma/ } \\
\text { Outros }\end{array}$ & Ed Dez & Ed Cem Editora \\
\hline $\begin{array}{l}\text { Tchan!/Os Sungas/Vixe } \\
\text { Mainha }\end{array}$ & Bicho da Selva & Bichinho Edições \\
\hline $\begin{array}{l}\text { Babado Novo/Nata do } \\
\text { Tchan/Toque Novo }\end{array}$ & & Fábrica da Música \\
\hline Chiclete com Banana & Mazana & $\begin{array}{l}\text { Babel } \\
\text { Granola }\end{array}$ \\
\hline Estakazero & Leke Produções & Leke Editora \\
\hline
\end{tabular}




\begin{tabular}{|c|c|c|}
\hline Terra Samba & $\begin{array}{l}\text { Terra Samba } \\
\text { Produções }\end{array}$ & $\begin{array}{l}\text { Terra Samba } \\
\text { Jerm Produções }\end{array}$ \\
\hline Motumbá & Motumbá & Motumbá Edições \\
\hline Selakuatro & Buxixos Produções & Buxixos Editora \\
\hline Pida! & Pida! & Pontual Editora \\
\hline Tenisson Del Rey & Faro Fino & Faro Fino Edições \\
\hline Netinho & Bem Bolado & Bem Bolado \\
\hline Rapazolla & Thibiron & Thibiron \\
\hline Ricardo Chaves & Rafa Produções & Rafa Edições \\
\hline Ademar da Furta Cor & $\begin{array}{l}\text { Periferia Estúdio e } \\
\text { Produções }\end{array}$ & $\begin{array}{l}\text { Furta Cor Edições } \\
\text { Musicais }\end{array}$ \\
\hline $\begin{array}{l}\text { Gerônimo/Alfredo } \\
\text { Moura e outros }\end{array}$ & Mundus et Fundus & $\begin{array}{l}\text { Mundus et Fundus } \\
\text { Edições }\end{array}$ \\
\hline Margareth Menezes & Central Produções & Estrela do Mar Edições \\
\hline Vários & Wave Music & Wave Music Edições \\
\hline Vários & Pato Discos & Pato Discos e Edições \\
\hline VoaDois & Penteventos & Penteventos \\
\hline Maianga & Maianga & Maianga \\
\hline Vários & MusiRoots & MusiRoots \\
\hline Vários & Vevel & Vevel \\
\hline Vários & $\begin{array}{l}\text { Plataforma de } \\
\text { Lançamento }\end{array}$ & $\begin{array}{l}\text { Plataforma de } \\
\text { Lançamento }\end{array}$ \\
\hline Vários & $\begin{array}{l}\text { WR Produtora e } \\
\text { Estúdio }\end{array}$ & WR Edições \\
\hline Vários & Stalo Produções & Stalo Edições \\
\hline Psirico & Penteventos & Xanguá \\
\hline Tomate & Penteventos & FK \\
\hline Estação CD & Estação CD & Estação CD \\
\hline
\end{tabular}




\begin{tabular}{|l|l|l|} 
Rede Bahia & Rede Bahia & Bahia Discos \\
Parangolé Pondé & Independente & Good Vibration \\
Alexandre Peixe & Salvador Produções & Sofá da Sogra \\
Lampirônicos & $\begin{array}{l}\text { Pequena Notável } \\
\text { Caatinga Cultura e } \\
\text { Entretenimento }\end{array}$ & Som de Peixe Edições \\
Gerônimo & $\begin{array}{l}\text { Arco e Flexa } \\
\text { Produções }\end{array}$ & Caatinga \\
Adelmário Coelho & $\begin{array}{l}\text { Daerje Produções } \\
\text { Perto da Selva } \\
\text { Produções }\end{array}$ & Daerje Editora \\
Vários & $\begin{array}{l}\text { Portela Fernandes } \\
\text { Representações }\end{array}$ & Perto da Selva \\
Vários & $\begin{array}{l}\text { Assoc. Carn. Bloco } \\
\text { Afro Olodum }\end{array}$ & Boão Portela \\
Olodum & $\begin{array}{l}\text { Grupo Cultural } \\
\text { Olodum }\end{array}$ & Grupo Cultural Olodum \\
Cacau com Leite & Jupará \\
Olodum & Cacau com Leite & Salodum \\
\hline
\end{tabular}

Quadro II - Editoras Musicais/Salvador

Fonte: Pesquisa de Campo do autor - março/2010.

Pode-se perceber, no quadro acima, a preponderância dos artistas relacionados ao universo da axé music, enquanto campo musical e simbólico ${ }^{6}$, apresentando boa parte dos artistas baianos deste gênero musical como também proprietários de editoras musicais, e, sendo assim, gestores de suas próprias obras musicais e repertórios. Neste estudo, é contemplada a gestão da obra musical também exercida diretamente pelo autor, ou aquela empreendida pelo empresário editor.

6 Compreendendo o campo simbólico como a territorialidade mediada pelos signos e símbolos, enquanto elementos "por excelência da integração social" (BOURDIEU, 1989), que possibilitam o consenso acerca do sentido do social - imprescindível à reprodução da ordem. Neste sentido, o próprio sentido de contemporâneo é constantemente ressignificado mediante as transformações econômicas, tecnológicas e sociais também constantes. 
Apesar do ineditismo e relevância das informações que compõem o quadro acima, nem todo artista/compositor baiano de relativo prestígio consegue estabelecer sua própria produtora e/ou editora musical. Dentre os fatores deste afunilamento, podemos nos referir à inexistência de projetos pessoais e/ou visão estratégica para tal e ao pouco conhecimento sobre o tema e suas potencialidades, entre outros.

Na cadeia produtiva musical, a etapa conhecida como edição musical é o processo pelo qual o compositor cede e transfere os direitos de administração de sua propriedade intelectual - neste caso, a obra musical - para uma organização/empresa legalmente constituída junto ao Ministério da Fazenda. Esta etapa pode ter temporalidade acordada entre as partes. A atividade de edição musical está amparada pela Lei de Direitos Autorais (9.610/98), além de Convenções e Tratados Internacionais, sendo o Brasil signatário de todos? .

Atualmente, as editoras musicais são as responsáveis pela arrecadação e pagamento de direitos autorais obtidos com a comercialização de produtos fonográficos e audiovisuais; legalização das obras e autores junto às associações arrecadadoras, e, posteriormente ao Escritório Central de Arrecadação e Distribuição (ECAD); acompanhamento e controle das liberações e pagamentos relativos aos direitos autorais junto às gravadoras Majors e selos musicais independentes ${ }^{8}$; assim como intermediárias entre o circuito comercial (produtores musicais) e os autores.

Com o processo de globalização, estando a pirataria e os avanços tecnológicos cada vez mais presentes no cotidiano, em formas diversificadas e atuantes, a gestão da obra musical teve de redirecionar suas atividades - antes focadas prioritariamente na

7 Existe, ainda, a Associação Brasileira de Editoras Musicais - ABEM, que orienta e informa suas associadas sobre as oportunidades do mercado, legislação e novidades acerca da administração da obra musical. 
arrecadação e pagamento de direitos autorais, via fonomecânicos (venda de CDs/DVDs) - para outros segmentos, como autorização para os ring tones e real tones, mercado da música digital e, principalmente, a arrecadação de direitos de execução pública, além da própria produção fonográfica de artistas locais e/ou nacionais.

Transitando entre o artista e o compositor, o editor musical é relevante na gestão da obra musical, pois, uma vez a obra editada - e dependendo dos termos do contrato de edição -, passa a ter mais autonomia e controle sobre a obra do que o próprio autor.

Sob outra ótica, a do artista, na trama contemporânea engendrada pelos avanços da telemática9 ${ }^{9}$ e da reestruturação pós-capitalista/fordista, dos avanços das transnacionais nos novos mercados e do competitivo mercado de eventos musicais e entretenimento, a administração da carreira musical deve ser estratégica, sendo que o artista/autor/editor representa a tomada de poder pelo próprio artista.

Esta etapa, marcada pela nacionalização do processo de produção fonográfica, tem início na década de 1970, a partir da iniciativa de artistas musicais descontentes com os modelos gerenciais exclusivistas das transnacionais em atividade no Brasil à época (ALMEIDA; PESSOTI, 2000; DE MARCHI, 2005) Dentre eles, destacam-se Chico Buarque, Caetano Veloso, Ivan Lins, Gilberto Gil, Ronaldo Bastos, Djavan e, mais recentemente, nomes como Roupa Nova, Marisa Monte, Flávio Venturini, Zeca Pagodinho, Tom Zé, Dado Villa Lobos, Tom Jobim e Milton Nascimento.

Este processo pode ser analisado também a partir da reestruturação pós-fordista do capitalismo, via acumulação flexível (HARVEY, 1992), em cujo processo a indústria fonográfica mun-

9 A telemática é entendida enquanto conjunto resultante da articulação entre os recursos das telecomunicações (telefonia, satélite, fibras óticas, etc) e da informática (computadores, periféricos, softwares e sistemas de redes), que possibilitam o processamento, a compressão, o armazenamento e a comunicação de grandes quantidades de dados (texto, imagem e som), em curto prazo de tempo, entre usuários localizados em qualquer ponto do planeta. 
dial redirecionou suas atividades, terceirizou etapas e expandiu-se para novos mercados. No Brasil, a aliança com os artistas nacionais favoreceu estes que, em muitos casos, adquiriram conhecimentos e propriedades na gestão; a propriedade dos fonogramas e da gestão das obras, entre outras.

\section{CONSIDERAÇÕES FINAIS}

A mera e descontextualizada compreensão, neste sentido, da suposta "crise" da axé music, tendo como argumentação central os índices e estatísticas da indústria fonográfica, mostra-se assim equivocada. Cabe reiterar, ainda, que os shows, e não a vendagem de produtos fonográficos, tornam-se a maior fonte de renda desses artistas. A indústria fonográfica é relevante no mercado de bens simbólicos, é bem verdade, mas sua participação não se configura como determinante e exclusivo fator ao sucesso. Seus principais interlocutores parecem saber disso, e, através de ações individuais ou coletivas (APA, ABT, entre outros), vêm se articulando junto a outras formas de promoção dos seus artistas e repertórios.

Entretanto, é inegável que o rápido sucesso desse gênero musical baiano contemporâneo estimulou comportamentos isomórficos envolvendo mercado e estética, que terminaram por estimular o surgimento de inúmeras produções com baixa qualidade técnica, inclusive.

Enquanto world music, a musicalidade baiana denominada axé music conjuga, exemplarmente, dois aspectos fundamentais: referência rítmica original (percussão) e fusão de gêneros, estilos e células musicais. A estes itens se associa o constante diálogo entre tradição e modernidade, no qual tambores e guitarras encontramse devidamente ensaiados e dispostos para embates ora sonoros, ora silenciosos. 
A axé music, em diversas unidades de análise, conseguiu estabelecer e manter relação com os principais organismos de comunicação e entretenimento do país, para muito além daquilo que se efetivava como seu período de festa e auge fonográfico. $\mathrm{O}$ preconceito estético relacionado à axé music não encontra lastro em seu campo real de shows, ensaios e estratégias competitivas visando à sobrevivência no acirrado mundo dos negócios deste segmento da indústria cultural. Artistas e empresários deste estilo musical tanto souberam estruturar estéticas como também a profissionalização e autonomização de um campo.

O desempenho econômico do estado - amplamente estruturado no setor de serviços - reconhece a relevância da axé music e do carnaval soteropolitano, sendo que, não raro, transforma seus principais artistas em estrelas de comerciais turísticos, numa missão de disseminar a marca Bahia, bem como de atender àqueles que, em níveis diferenciados, desenvolveram uma percepção especial acerca desta territorialidade.

Por outro lado, pensar a axé music com exclusividade no âmbito das relações comerciais, via indústria fonográfica, de produtos individualizados e personalizados é outro equívoco, uma vez que, anualmente, inúmeras coletâneas deste gênero musical são lançadas no mercado nacional e internacional.

Pop e world music, a axé music é uma dinâmica articulada e rizomática no mercado de bens simbólico-culturais, satisfazendo parcela relevante de um mundo ávido por dinâmicas musicais cotidianas do outro, do estranho, do exótico, do efêmero e do diverso. Pode-se afirmar também que é a referencialidade de uma Bahia notabilizada por suas próprias canções, compositores, músicos e artistas que se tornaram empresários e que aprenderam a fazer e exportar a música de um estado com larga barra quando o assunto é Brasil. 


\section{REFERÊNCIAS}

ALMEIDA, P. H.; PESSOTI, G. A evolução da indústria fonográfica e o caso da Bahia. Revista Bahia Análise e Dados. v.9 n.4 p.90-108. Salvador: SEI, 2000.

ASSOCIAÇÃO BRASILEIRA DE PRODUTORES DE DISCO. Relatório anual da Associação Brasileira de Produtores de Discos. Rio de Janeiro, 2008.

BOURDIEU, P. O poder simbólico. Rio de Janeiro: Bertrand Brasil, 1989.

CANCLINI, Néstor García. Culturas híbridas - estratégias para entrar e sair da modernidade. São Paulo: EDUSP, 2003.

CASTORIADIS, C. A instituição imaginária da sociedade. Rio de Janeiro: Paz e Terra, 2000.

CONCEIÇÃO, Mário. Itaim para o Candeal. In:

TIMBALADA. Timbalada. [s.1.]: Philips/Polygran, 1993.

DANTAS, Marcelo. Competitividade internacional em turismo: a identidade cultural contra o mito da qualidade de serviços. Revista Texto e Contextos, Salvador, ano 3, n. 4 jul./dez. 2005.

. OLODUM - De bloco afro a holding cultural. Salvador:

Edições Olodum, Editora da Fundação Casa de Jorge Amado, 1994.

DEBORD, G. A sociedade do espetáculo - comentários sobre a sociedade do espetáculo. Rio de Janeiro: Contraponto, 1997.

DE MARCHI, Leonardo. A Angústia do Formato: uma História dos Formatos Fonográficos. In: E-Compós. Disponível em:<http://www. compos.org.br/ecompos/>. Acesso: abril de 2005.

DI MAGGIO, P. J.; POWELL, W. W. The iron cage revisited:

institutional isomorphism and collective rationality in organizational fields. Administrative Science Review, v. 8, n. 2, p. 147-169, 1983.

ELIAS, Norbert. A sociedade de corte. Rio de Janeiro: Jorge Zahar, 1995 .

HALL, Stuart. A identidade cultural na pós-modernidade. Rio de Janeiro: DP\&A, 1999.

HARVEY, David. Condição pós-moderna: uma pesquisa sobre as origens da mudança cultural. São Paulo: Edições Loyola, 1992. 
GILROY, Paul. The black atlantic modernity and double consciouness. London: Verso, 1993.

GUERREIRO, G. A trama dos tambores - a música afro-pop de Salvador. São Paulo: Editora 34, 2000.

IANNI, Octavio. Teorias da globalização. Rio de Janeiro: Civilização Brasileira, 1999.

LIMA, Ari. Funkeiros, timbaleiros e pagodeiros: notas sobre juventude e música negra na cidade de Salvador. Caderno Cedes. Campinas, 2002.

MIGUEZ, Paulo. A organização da cultura na "cidade da Bahia”. 2002. 348 f. Tese (Doutorado em Comunicação e Cultura Contemporânea) - Faculdade de Comunicação, Universidade Federal da Bahia. Salvador.

MOURA, Milton. Produtora, Mercadora, Mercadoria. Uma cidade para o Carnaval? In: FISCHER, Tânia (org). O Carnaval Baiano. Negócios e oportunidades. Brasília: SEBRAE, 1996. Pg. 59-65. . Carnaval e baianidade: arestas e curvas na coreografia de identidades do carnaval de Salvador. 2001. 378 f. Tese (Doutorado em Comunicação e Cultura Contemporânea) - Faculdade de Comunicação , Universidade Federal da Bahia. Salvador.

CONCEIÇÃO, Mário. Itaim para o candeal. In: Timbalada. Rio de Janeiro: Polygram, p.1993. Faixa 11.

SAHLINS, M. Cultura e razão prática. Rio de Janeiro: Jorge Zahar, 2003.

SILVA, Elaine Norberto. Consumo, mimesis e sentido. In.:

VALVERDE, Monclar (Org.). As formas do sentido. Rio de Janeiro: DP\&A, 2003. 



\section{SOBRE OS AUTORES}

\section{Olivia Biasin}

Mestre em História pela UFBA (2007). Desenvolve o Doutorado em História na mesma Universidade, com bolsa CAPES. Membro do Grupo de Pesquisa O Som do Lugar e o Mundo.

E-mail: oliviabiasin@oi.com.br.

\section{Edilece Souza Couto}

Doutora em História pela UNESP (2004). Professora do Departamento e do Programa de Pós-Graduação em História da UFBA. Desenvolve pesquisas no âmbito da História Religiosa. Autora de A puxada do mastro (Maramata, 2001) e Tempo de festas (Edufba, 2010). Membro do Grupo de Pesquisa O Som do Lugar e o Mundo. E-mail: edilece@ufba.br.

\section{Milton Moura}

Doutor em Comunicação e Cultura Contemporâneas pela UFBA (2001). Professor do Departamento e do Programa de Pós-Graduação em História da mesma Universidade. Desenvolve pesquisas sobre História da Festa em Salvador e na Baía de Todos os Santos e da música popular no Brasil, com apoio CNPq. Coordena o Grupo de Pesquisa O Som do Lugar e o Mundo.

E-mail: araujomoura@terra.com.br.

Christine Nicole Zonzon

Mestre em Ciências Sociais pela UFBA (2007). Desenvolve o Doutorado em Ciências Sociais na mesma Universidade, com uma pesquisa sobre as articulações entre a corporeidade e as identidades na capoeira, contando com bolsa CNPq. Pratica capoeira angola desde 1989, em Salvador. Membro do Grupo de Pesquisa O Som do Lugar e o Mundo. E-mail: criszom2@gmail.com. 


\section{Luciana Vasconcelos}

Mestre em Cultura e Sociedade pela UFBA (2008). Produtora e gestora cultural na área de música, teatro e artes visuais. Dirigiu o Teatro Molière da Aliança Francesa de Salvador (2003/04) e atua na produção de espetáculos internacionais e projetos de intercâmbio cultural. Coordenou a produção executiva de projetos artísticos que integraram a programação do Ano do Brasil na França (2005) e do Ano da França no Brasil (2009).

E-mail: lucianavasconcelos1@gmail.com.

Armando Alexandre Castro

Doutor em Administração pela UFBA (2011). Mestre em Cultura e Turismo pela UESC/UFBA (2005). Professor de Cultura Artística da UFBA - Campus Barreiras. Autor do livro Irmãs de fé: tradição e turismo no Recôncavo Baiano (E-papers, 2006). Atuou como produtor cultural no âmbito da música e artes visuais. Desenvolve pesquisas sobre música, turismo e gestão cultural. Membro do Grupo de Pesquisa O Som do Lugar e o Mundo.

E-mail: armandocastro5@yahoo.com.br. 



\begin{tabular}{|c|c|}
\hline & COLOFÃO \\
\hline Formato & $17 \times 24 \mathrm{~cm}$ \\
\hline Tipologia & $\begin{array}{l}\text { Georgia 11/16 (Texto) } \\
\text { Centabel Book e Bell Gothic Std }\end{array}$ \\
\hline Papel & $\begin{array}{l}\text { Alcalino } 75 \mathrm{~g} / \mathrm{m}^{2} \text { (miolo) } \\
\text { Cartão Supremo } 300 \mathrm{~g} / \mathrm{m}^{2} \text { (capa) }\end{array}$ \\
\hline Impressão & Setor de Reprografia da EDUFBA \\
\hline Capa e Acabamento & Cartograf \\
\hline Tiragem & 500 \\
\hline
\end{tabular}

